A CALL TO CITIZENSHIP: ANTI-KLAN ACTIVISM IN MISSOURI, 1921-1928

A Dissertation
presented to
the Faculty of the Graduate School
at the University of Missouri-Columbia
In Partial Fulfillment
of the Requirements for the Degree
Doctor of Philosophy
beAN ROST
Dr. Catherine Rymph, Dissertation Supervisor

July 2018 
(C) Copyright by Sean Rost 2018

All Rights Reserved 
The undersigned, appointed by the dean of the Graduate School, have examined the dissertation entitled

\section{A CALL TO CITIZENSHIP: ANTI-KLAN ACTIVISM IN MISSOURI, 1921-1928}

presented by Sean Rost,

a candidate for the degree of doctor of philosophy,

and hereby certify that, in their opinion, it is worthy of acceptance.

Assoc. Professor Catherine Rymph

Adj. Asst. Professor Larry Brown

Asst. Professor Keona Ervin

Professor Jeffrey Pasley

Professor John Wigger 


\section{DEDICATION}

To My Family 


\section{ACKNOWLEDGEMENTS}

Acknowledgements can be tricky. On the one hand, you want to thank individuals who helped the project to completion. On the other hand, you constantly worry that someone will get left out. Needless to say, in writing the acknowledgement, one realizes just how many people contributed to the overall project. While the author receives the attention, those who worked behind the scenes deserve recognition. But before I dispense with the long list of thank you's, I want to thank you, the reader, for finding this work. It is my hope that the story interwoven in the following pages will not end at the conclusion of this project, but will go forth to aid countless other projects that tackle difficult historical topics.

The research and writing time necessary for this dissertation would not have been possible without fellowships and grants from generous institutions. I would like to thank the following for their support of this project: Dissertation Fellowship and William Wilcher Endowment Grant from the Department of History at the University of Missouri, James S. Rollins Slavery Atonement Endowment from the Black Studies Department at the University of Missouri, Graduate Fellowship in American Political History and Research Grant from the Kinder Institute on Constitutional Democracy, Research Grant from the Cushwa Center for the Study of American Catholicism at the University of Notre Dame, and the John Tracy Ellis Dissertation Award from the American Catholic Historical Association. 
Though historians sometimes get attention for "uncovering" new materials, there are archivists, librarians, and scholars around the world who deserve immense credit for collecting and processing these collections for the general public. With this in mind, I would like to thank the staff of the University of Notre Dame Archives, Special Collections Research Center at the University of Chicago, Indiana Historical Society, Archives \& Special Collections at Ball State University, Library \& Research Center of the Missouri Historical Society, Archdiocese of St. Louis' Office of Archives and Records, David M. Rubenstein Rare Book \& Manuscript Library at Duke University, Missouri State Archives, Pius XII Memorial Library at St. Louis University, Missouri River Regional Library, Ellis Library's Special Collections \& Rare Books at the University of Missouri, and the Library of Congress. Of particular note were Rod Chapel, President of the Missouri NAACP; Gary Cox of the University of Missouri Archives; Janet Olson of the Frances Willard House Museum \& Archives; and VivianLea Solek of the Knights of Columbus Supreme Council Archives. Finally, I'd like to thank my amazing colleagues at the State Historical Society of Missouri and the Missouri Humanities Council, especially Gary Kremer and Steve Belko, who helped this project in innumerable ways from start to finish.

While deserved credit goes to those both on and off campus, I would be remiss if I didn't acknowledge the scholarly community of faculty, staff, and graduate students that exists in Read Hall and at the Kinder Institute on Constitutional Democracy. A graduate student writing group that featured Craig Forrest, Chris Deutsch, Carey Kelly, and Sam Rogers helped the structure, formatting, argument, and resources of each chapter immensely. You all helped this project in more ways than you realize. Additionally, 
since there was a significant overlap between our projects, Mary Beth Brown provided exceptional guidance on a number of subjects, including research collections to review, scholarly literature to read, and individuals to contact during the dissertation. Several components of this project were made fuller after conversations about her own dissertation. Finally, I found tremendous scholarly and morale support from Sarah Lirley McCune, Brandon Flint, Luke Schleif, Caitlin Lawrence, Danielle Griego, Zach Dowdle, Jonathan Jones, Will Mountz, Josh Nudell, Hunter Hampton, Jonathan Root, Darin Tuck, Jenna Rice, Lawrence Celani, and Cassie Yacovazzi.

My dissertation committee was the best. Each member provided valuable and essential contributions that guided this project from a small study of a few Missouri counties to a wide-sweeping look at the entire state. Keona Ervin's coursework on African American History shaped my understanding of how civil rights activism took on many forms. John Wigger's graduate classes on American Religious History peaked an interest in the subject that I never knew existed. Larry Brown guided me through the specifics of white supremacist organizations and ideologies in United States History, especially those that continue to dwell within Missouri. Jeff Pasley constantly challenged me to do better. Not only did he suggest a state-wide study, but he made sure that this project did not come to simple conclusions. Finally, Catherine Rymph served as my advisor and one of my most ardent supporters. This dissertation would not have been possible without her guidance and wisdom. I am a better scholar, teacher, and person because of my time as her student. There is not enough space in this acknowledgement to thank her properly. 
Last, but certainly not least, I must thank my amazing family. You all were always there for me and never gave up on this dream. You showed support, and at times, even tough love. My parents, David and Pam, offered substantial help during my lengthy time in graduate school, including my father serving as my research assistant at the Library of Congress. My in-laws, Tim \& LaDonne, Paige \& Dan, Kayla \& Jordan, were ready and willing to assist my wife when it came to childcare and playdates so I could research, write, and teach. With the exception of my daughter, my remaining children were all born at some point during the dissertation process. You offered me smiles, laughs, and comfort while Dad had "work" to do. Finally, my wife, Adrienne, was essential to this project. Her love and support put every single word on all these pages. 


\section{TABLE OF CONTENTS}

ACKNOWLEDGEMENTS ..................................................

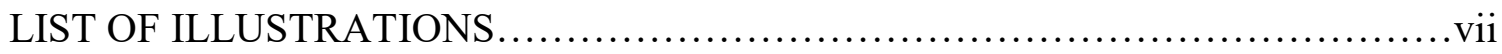

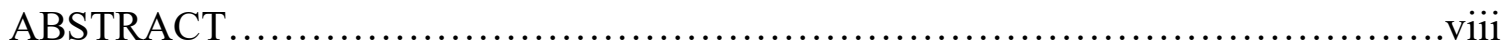

\section{CHAPTER}

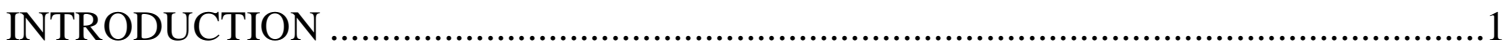

1. The Dead Men......................................................... 20

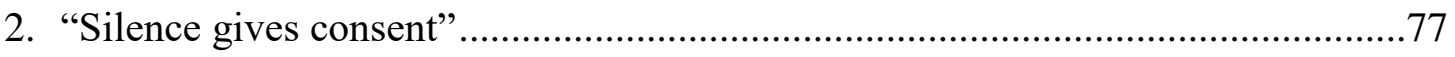

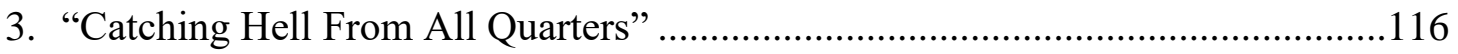

4. "The Eyes of the Nation are upon Missouri" ...................................................176

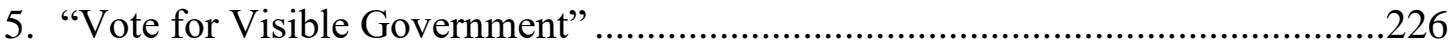

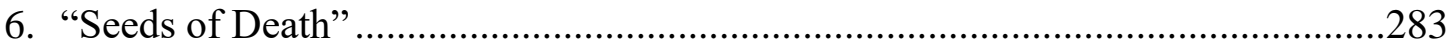

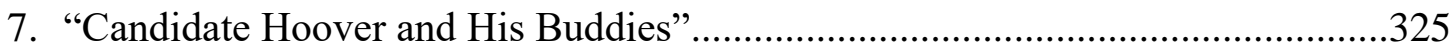

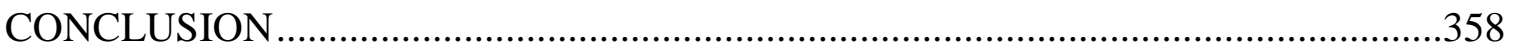

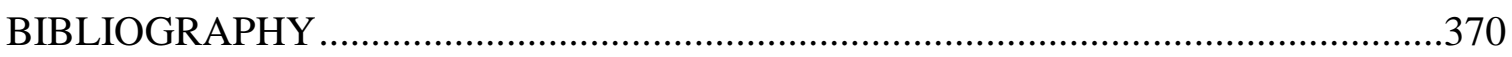

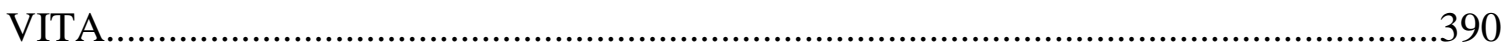




\section{LIST OF ILLUSTRATIONS}

$\begin{array}{lll}\text { Figure } & \text { Page }\end{array}$

1. Map of Missouri Counties ..................................................................................

2. Klan activity in Missouri (July 1923-December 1924).........................................11 


\title{
A CALL TO CITIZENSHIP: ANTI-KLAN ACTIVISM IN MISSOURI, 1921-1928
}

\author{
Sean Rost \\ Dissertation Supervisor: Dr. Catherine Rymph
}

ABSTRACT

This dissertation examines the efforts of anti-Klan activists in Missouri to challenge the growth, recruitment, and political ambitions of the Ku Klux Klan during the 1920s. As a nation-wide organization, the Klan made major inroads in Missouri and built a substantial membership population that replicated similar growth in other states. However, as this dissertation argues, the Klan was unable to translate its recruiting success in Missouri into political power due to significant local opposition. These anti-Klan activists came from diverse backgrounds, and included newspaper editors, members of organizations such as the NAACP, UNIA, Urban League, Catholic Central Verein, Knights of Columbus, and B'nai B'rith, and prominent state politicians such as Governor Arthur Hyde, Senator James A. Reed, and Congressman Harry Hawes. At times, they tried to unite into an interracial, interdenominational, and bipartisan Klan-fighting organization; yet, personal quarrels and internal differences over how best to challenge the hooded order splintered any hope of a singular coalition. Nevertheless, anti-Klan activists did experience some success in using their power in the press, the pulpit, and the polls to stymie the growth of the Klan's Invisible Empire in the state. 


\section{Introduction}

In May 1921, two members of the St. Louis National Association for the Advancement of Colored People (NAACP), George L. Vaughn and Cora J. Carter, wrote letters to NAACP officials in New York alerting them to the activities of the local branch. Noting efforts by the group to pressure Governor Arthur Hyde into conducting a thorough investigation into the recent lynching of Roy Hammonds in nearby Bowling Green, Missouri, George L. Vaughn proudly told national members that the "St. Louis Branch of the N.A.A.C.P. is quite active these days."1 Among the numerous issues undertaken by the St. Louis branch, local members had turned their attention most to the recent arrival of the Ku Klux Klan in the city. Vaughn indicated as much in his letter to the national headquarters when he advised them that "[b]esides conducting the drive for Membership, which is succeeding, the Branch is fighting the efforts to organize the $\mathrm{Ku}$ Klux Klan in Missouri."2

Like her fellow St. Louis branch member, Cora Carter also felt it necessary to alert New York officials about Klan activity in Missouri. Her telegram to Executive Secretary James Weldon Johnson expressed concern regarding recent Klan recruitment but also inquired about how other NAACP branches dealt with the hooded order. ${ }^{3}$

\footnotetext{
${ }^{1}$ George L. Vaughn to N.A.A.C.P., 16 May 1921, Folder 19, Box 1: G109, National Association for the Advancement of Colored People Collection (hereafter cited as NAACP), Library of Congress, Washington D.C. (hereafter cited as LOC).

${ }^{2}$ George L. Vaughn to N.A.A.C.P., 16 May 1921, Folder 19, Box 1: G109, NAACP, LOC.

${ }^{3}$ Cora J. Carter to James Weldon Johnson, 13 May 1921, Western Union Telegram, Folder 19, Box 1: G109, NAACP, LOC.
} 
Responding immediately Assistant Secretary Walter White advised Carter and her fellow St. Louis members to pressure the mayor, police department, governor, and various city and state officials into stating their position on the Klan. In a tactic frequently used by anti-Klan activists, White wanted prominent officials to be on record regarding their opinion of the so-called "Invisible Empire." White also recommended that NAACP members contact local newspapers and convince them to write about the Klan. Under such a plan, newspapers would run exposes and damning editorials about the organization, thus significantly impacting local recruitment. ${ }^{4}$ Finally, White called on NAACP members to launch an interracial and interdenominational coalition that would effectively challenge the growth of the Ku Klux Klan:

May I strongly urge that you get in touch with organizations like the Knights of Columbus and other IrishCatholic groups; the B'Nai Brith and other Jewish organizations; the local labor groups such as the American Federation of Labor emphasizing upon all of these that the $\mathrm{Ku}$ Klux Klan is not only Anti-Negro but Anti-Catholic, Anti-Semitic, and Anti-Labor. We also suggest that you enlist the active opposition to the Klan of church and civic organizations. ${ }^{5}$

Upon receiving a packet of anti-Klan pamphlets from the NAACP's headquarters, Cora Carter distributed the information to "others that are interested in the suppression of this tyrannical organization" and expressed hope that "our Branch shall be equally as successful [as New York] in the end." ${ }^{6}$

\footnotetext{
${ }^{4}$ Walter White to Cora J. Carter, 13 May 1921, Western Union Telegram, Folder 19, Box 1: G109, NAACP, LOC.

${ }^{5}$ Walter White to Cora J. Carter, 13 May 1921, Folder 19, Box I: G109, NAACP, LOC.

${ }^{6}$ Cora J. Carter to Walter White, 1 June 1921, Folder 19, Box 1: G109, NAACP, LOC.
} 
Six years prior to Vaughn and Carter's correspondence, in 1915, William Joseph Simmons spent an eventful three months confined to an Atlanta hospital. Recovering from an automobile accident, Simmons occupied most of his time dreaming of an organization that would replicate the Lost Cause lore of the original Ku Klux Klan. A former Methodist circuit rider, Simmons thought of starting his own fraternal organization while serving as a local organizer for the Woodmen of the World. Developing titles and terms based on mythology and the Reconstruction Klan, Simmons rallied recruits to his cause throughout Atlanta. Soon after, the Ku Klux Klan's rebirth occurred in a cross burning ceremony on top of Georgia's Stone Mountain. ${ }^{7}$ Though the Klan initially became popular in and around Atlanta, historian Shawn Lay has argued that in the early years "it appeared highly unlikely that the second Klan would ever develop a following in places [far outside the South]." ${ }^{\circ}$ Indeed, at first, the second Klan remained relatively obscure. It was a fraternal organization among hundreds of other such organizations.

\footnotetext{
${ }^{7}$ Nancy K. MacLean, Behind the Mask of Chivalry: The Making of the Second Ku Klux Klan (Oxford: Oxford University Press, 1994), 4-5; Shawn Lay, Hooded Knights on the Niagara: the Ku Klux Klan in Buffalo, New York (New York: New York University Press, 1995), 2-4; Shawn Lay, ed., The Invisible Empire in the West: Toward a New Historical Appraisal of the Ku Klux Klan of the 1920s (Urbana: University of Illinois Press, 1992), 3-8; Kelly J. Baker, Gospel according to the Klan: the KKK's Appeal to Protestant America, 1915-1930 (Lawrence: University of Kansas Press, 2011), 4-5; David Chalmers, Hooded Americanism: The History of the Ku Klux Klan (Chicago: Quadrangle Books, 1968), 28-38; Larry R. Gerlach, Blazing Crosses in Zion: the Ku Klux Klan in Utah (Logan: Utah State University Press, 1982), 4-7; Wyn C. Wade, The Fiery Cross: the Ku Klux Klan in America (Oxford: Oxford University Press, 1998), 140-166; William D. Jenkins, Steel Valley Klan: the Ku Klux Klan in Ohio's Mahoning Valley (Kent: Kent State University Press, 1990), 1-4; Kathleen Blee, Women of the Klan: Racism and Gender in the 1920s (Berkeley: University of California Press, 1991), 17-21. Linda Gordon, The Second Coming of the KKK: The Ku Klux Klan of the 1920s and the American Political Tradition (New York: Liveright, 2017), 11-16; Felix Harcourt, Ku Klux Kulture: America and the Klan in the 1920s (Chicago: University of Chicago Press, 2017), 2-4; Robert A. Goldberg, Hooded Empire: the Ku Klux Klan in Colorado (Urbana: University of Illinois Press, 1981), 3-5; Thomas Pegram, One Hundred Percent American: The Rebirth and Decline of the Ku Klux Klan in the 1920s (Chicago: Ivan R. Dee, 2011), 5-10.

${ }^{8}$ Lay, Hooded Knights on the Niagara, 2.
} 
This changed dramatically, however, in 1920. In that year, Simmons obtained the services of the Southern Publicity Association. Headed by Edward Young Clarke and Elizabeth Tyler, the Southern Publicity Association had previously worked with the Salvation Army, Red Cross, and the Anti-Saloon League. Clarke and Tyler helped transform the second Klan from an obscure fraternal organization into a "patriotic" group concerned about "core American values," including white supremacy. The concerns of the first Klan, primarily violently resisting African American rights, now expanded to include immigrants, Catholics, Jews, and many of the "new" groups in society. Relying on modern advertising and sales techniques, Clarke and Tyler sent recruiters (kleagles) out to communities across the country to sell Americanism and Klan membership at ten dollars per person. When a kleagle arrived in a community, they tailored their recruiting message to local concerns. Themes ranged from law enforcement, declining morality, and fraternal bonding to white supremacy, anti-Catholicism, and anti-Semitism. Kleagles frequently contacted local leaders of fraternal orders as well as clergymen. This allowed for a higher stage, or pulpit, from which to recruit from. The result was instantaneous. By 1921, the Klan's membership had skyrocketed from a few thousand to around 100,000. Klan chapters (klaverns) sprouted in towns throughout the American South, the Midwest, and the Southwest. ${ }^{9}$

This second Ku Klux Klan that appealed to so many Americans may have seemed new, but its history dated back to the Reconstruction period. Though its first incarnation

\footnotetext{
${ }^{9}$ MacLean, Behind the Mask of Chivalry, 4-5; Lay, Hooded Knights on the Niagara, 2-4; Lay, ed., The Invisible Empire in the West, 3-8; Baker, Gospel According to the Klan, 4-5; Chalmers, Hooded Americanism, 28-38; Gerlach, Blazing Cross in Zion, 4-7; Wade, The Fiery Cross, 140-166; Jenkins, Steel Valley Klan, 1-4; Blee, Women of the Klan, 17-21; Gordon, The Second Coming of the KKK, 11-16; Harcourt, Ku Klux Kulture, 2-4; Pegram, One Hundred Percent American, 5-10.
} 
existed for less than a decade and was known for terror and violent vigilantism directed against free blacks, Republicans, and the white southerners who aided them, the Reconstruction Klan remained etched in the minds of early $20^{\text {th }}$ century Americans as "heroes" in a time of crisis. This memory of a "heroic" Klan was built upon the romanticism of the Lost Cause and the scholarship of men like William Dunning, a prominent professor at Columbia University. Americans "forgot" what truly happened all those years ago at the close of the Civil War; and instead, developed a perspective on Reconstruction that focused on the corruption and excesses of the period. In this view, rights were taken away from white southerners in favor of "semi-barbarous" blacks and white unionists. Opposition to Radical Republican policies, as the redeemer governments had touted decades earlier, became acceptable and respectable; and the leaders of such groups, particularly the Ku Klux Klan, were celebrated. ${ }^{10}$

In addition to the newly embraced historical memory of Reconstruction, popular culture, in its "theatrical" celebration of southern redemption, also aided the growth of the Klan. ${ }^{11}$ This point was not lost on the St. Louis Star which noted that "the mystery in which it is veiled stirs a sense of vanity, and there is a strong social element in its makeup, with a romantic glamor over its activities...the Ku Klux movement is quite like a movie stunt...[and] the real reason for its revival is doubtless the interest in the old $\mathrm{Ku}$ Klux stirred by 'The Birth of a Nation."”12 The film Birth of a Nation was D.W.

${ }^{10}$ Lay, ed., The Invisible Empire in the West, 3-8.

11 MacLean, Behind the Mask of Chivalry, 12-13; Lay, Hooded Knights on the Niagara, 5; Lay, ed., The Invisible Empire in the West, 3-8; Baker, Gospel According to the Klan, 4-5; Chalmers, Hooded Americanism, 22-30; Gerlach, Blazing Crosses in Zion, 2-3; Wade, The Fiery Cross, 119-139.

12 St. Louis Star, 12 May 1921. 
Griffith's masterpiece about the Lost Cause. Adapted from Thomas Dixon's novel The Clansman which glorified the Klan and its efforts to "save" southern life and culture, Griffith's Birth of a Nation became an epic production on an unprecedented scale. For many Americans, Griffith's focus on historical facsimile blurred the lines between reality and fiction. The scenes that played out in front of millions of Americans became, as President Woodrow Wilson reportedly defined them, "like writing history with lightning." Premiering in 1915, The Birth of a Nation appeared in theaters throughout the United States. It arrived to rave reviews in Missouri in October 1915 and by December made its way to Atlanta, Georgia. As the film premiered in Atlanta, Simmons was organizing his fraternal re-creation of the Ku Klux Klan that appeared as the heroic saviors at the conclusion of the film. ${ }^{13}$

William Simmons could not have found a better time to revive the Invisible Empire. Building upon racial, religious, and xenophobic fears of many Americans, the Klan's new Imperial Wizard was able to appeal to white supremacy and establish an organization that numbered in the millions by the middle of the 1920s. Yet, for all of its recruiting successes and modern advertising branding, the second Ku Klux Klan never dominated American society like its founder and early leaders had hoped. While the Klan was especially strong in states like Indiana, Colorado, and Oregon, it could not replicate similar successes throughout the United States. Additionally, a series of scandals involving high ranking officials like Simmons, E.Y. Clarke, John Galen Locke, and D.C. Stephenson contributed to the organization's decline in the latter half of the

${ }^{13}$ MacLean, Behind the Mask of Chivalry, 12-13; Lay, Hooded Knights on the Niagara, 5; Lay, ed., The Invisible Empire in the West, 3-8; Baker, Gospel According to the Klan, 4-8; David Chalmers, Hooded Americanism, 22-30; Gerlach, Blazing Crosses in Zion, 2-3; Wade, The Fiery Cross, 119-139. 
decade. By 1930, the Klan was a shell of its former self with a population that had dipped to roughly 50,000. ${ }^{14}$ Nevertheless, as scholars such as Kelly J. Baker, Linda Gordon, and Felix Harcourt note, the Klan was successful in making many of its views mainstream in American culture. ${ }^{15}$ Though many Americans would like to claim that the Klan is and was a fringe organization, it cannot be overlooked that the Klan was so successful in the early $20^{\text {th }}$ century because a significant portion of the country's population embraced its message.

Since its heyday during the 1920s, scholars and writers have attempted to dissect the Klan to understand its appeal. Even as crosses burned during the decade, John Moffatt Mecklin and Henry P. Fry, himself a former Klansmen, authored prominent books that addressed the group. ${ }^{16}$ Not one to miss out in a critique of 1920 s American culture, the writer Frederick Lewis Allen concluded that the Klan provided a "chance to dress up the village bigot and let him be a Knight of the Invisible Empire."17 The arguments put forth by these men, particularly Mecklin, that "the Klan draws its members chiefly from the descendants of the old American stock living in the villages and small towns of those sections of the country," dominated scholarship on the Klan until the 1950s when a new generation of scholars found that concerns over a loss of status in a modern and diverse world transformed rural and urban men into moral vigilantes who

${ }^{14}$ Blee, Women of the Klan, 175.

${ }^{15}$ Baker, Gospel According to the Klan; Gordon, The Second Coming of the KKK, 2-8; Harcourt, Ku Klux Kulture, 5-11.

${ }^{16}$ John M. Mecklin, The Ku Klux Klan: A Study of the American Mind (New York: Harcourt, Brace, and Company, 1924); Henry P. Fry, The Modern Ku Klux Klan (Boston: Small, Maynard and Company Publishers, 1922).

${ }^{17}$ Frederick L. Allen, Only Yesterday: An Informal History of the 1920s (New York: Harper Collins Publishers, 2000), 57. 
turned to the Klan to preserve their traditional way of life. ${ }^{18}$ These new scholars, particularly Charles Alexander, David Chalmers, and Kenneth Jackson, came to their conclusions about the Klan largely due to the resurgence of hooded violence during the post-World War II civil rights movement. ${ }^{19}$ While later scholars critiqued the conclusions on status anxiety, the efforts by Alexander, Chalmers, and Jackson to utilize surviving Klan records continues to dominate the study of the Invisible Empire. More recent scholarship from the likes of Robert Goldberg, Shawn Lay, William Jenkins, Leonard Moore, Kathleen Blee, Nancy MacLean, and Kelly J. Baker continues to utilize these records while also lifting back the white hood to reveal the social, political, economic, religious, and gendered dynamics of the second Klan. ${ }^{20}$

While recent scholarship on the $\mathrm{Ku}$ Klux Klan has provided a detailed understanding of the hooded order, there continues to be new areas to examine. This project seeks to provide a new perspective in the study of the 1920s Ku Klux Klan in three ways. First, I want to build on existing scholarship of the second Klan at the local level by focusing on Missouri, a state which has not received considerable attention.

${ }^{18}$ Mecklin, The Ku Klux Klan, 99.

${ }^{19}$ Charles Alexander, The Ku Klux Klan in the Southwest (Lexington: University of Kentucky Press, 1965); David M. Chalmers, Hooded Americanism: The History of the Ku Klux Klan (Chicago: Quadrangle Books, 1968); Kenneth T. Jackson, The Ku Klux Klan in the City, 1915-1930 (New York: Oxford University Press, 1967).

${ }^{20}$ Robert A. Goldberg, Hooded Empire: the Ku Klux Klan in Colorado (Urbana: University of Illinois Press, 1981); Shawn Lay, ed., The Invisible Empire in the West: Toward a New Historical Appraisal of the Ku Klux Klan of the 1920s (Urbana: University of Illinois Press, 1992); William D. Jenkins, Steel Valley Klan: the Ku Klux Klan in Ohio's Mahoning Valley (Kent: Kent State University Press, 1990); Leonard J. Moore, Citizen Klansmen: the Ku Klux Klan in Indiana, 1921-1928 (Chapel Hill: University of North Carolina Press, 1991); Shawn Lay, Hooded Knights on the Niagara: the Ku Klux Klan in Buffalo, New York (New York: New York University Press, 1995); Kathleen M. Blee, Women of the Klan: Racism and Gender in the 1920s (Berkeley: University of California Press, 1991); Nancy MacLean, Behind the Mask of Chivalry: The Making of the Second Ku Klux Klan. (Oxford: Oxford University Press, 1994); Kelly J. Baker, Gospel according to the Klan: the KKK's Appeal to Protestant America, 1915-1930. (Lawrence: University of Kansas Press, 2011). 
Outside of a collection of secondary literature that references local Klan activity, Missouri has not garnered a sizable monograph that analyzes the Invisible Empire within its borders. ${ }^{21}$ The state of Missouri provides an excellent case study for the rise and fall of the second Klan. In Missouri, the Klan gained a large membership, spread its message of Americanization, and obtained a decent level of political power in some areas of the state, especially Joplin and St. Joseph. These efforts, though, were mostly thwarted due to a large anti-Klan sentiment in the region, particularly in Kansas City and St. Louis. The efforts of Missourians - from farmers to congressional politicians - to distance themselves from the Klan and openly oppose its tenets and reform ideas reduced the Klan to a relatively powerless organization at the state level. As such, the Ku Klux Klan was not able to achieve the success and power in Missouri equivalent to that of neighboring states due to this opposition.

${ }^{21}$ Chalmers, Hooded Americanism; Jackson, The Ku Klux Klan in the City; Barbara J. Rush, The Ku Klux Klan in Kansas City during the Twenties (Master's Thesis, Marquette University, 1970); Jarod Roll, Spirit of Rebellion: Labor and Religion in the New Cotton South (Urbana: University of Illinois Press, 2010); Sherry Lamb Schirmer, A City Divided: The Racial Landscape of Kansas City, 1900-1960 (Columbia: University of Missouri Press, 2002); Franklin D. Mitchell, Embattled Democracy: Missouri Democratic Politics, 1919-1932 (Columbia: University of Missouri Press, 1968); John Judson Large, The "Invisible Empire" and Missouri Politics: the Influence of the Revived Ku Klux Klan in the Election Campaign of 1924 as reported in Missouri Newspapers (Master's thesis, University of Missouri-Columbia, 1957); Richard S. Kirkendall, A History of Missouri: Volume V, 1919 to 1953 (Columbia: University of Missouri Press, 1986); Lorenzo J. Greene, Gary R. Kremer, and Antonio F. Holland, Missouri's Black Heritage: Revised Edition (Columbia: University of Missouri Press, 1993). 


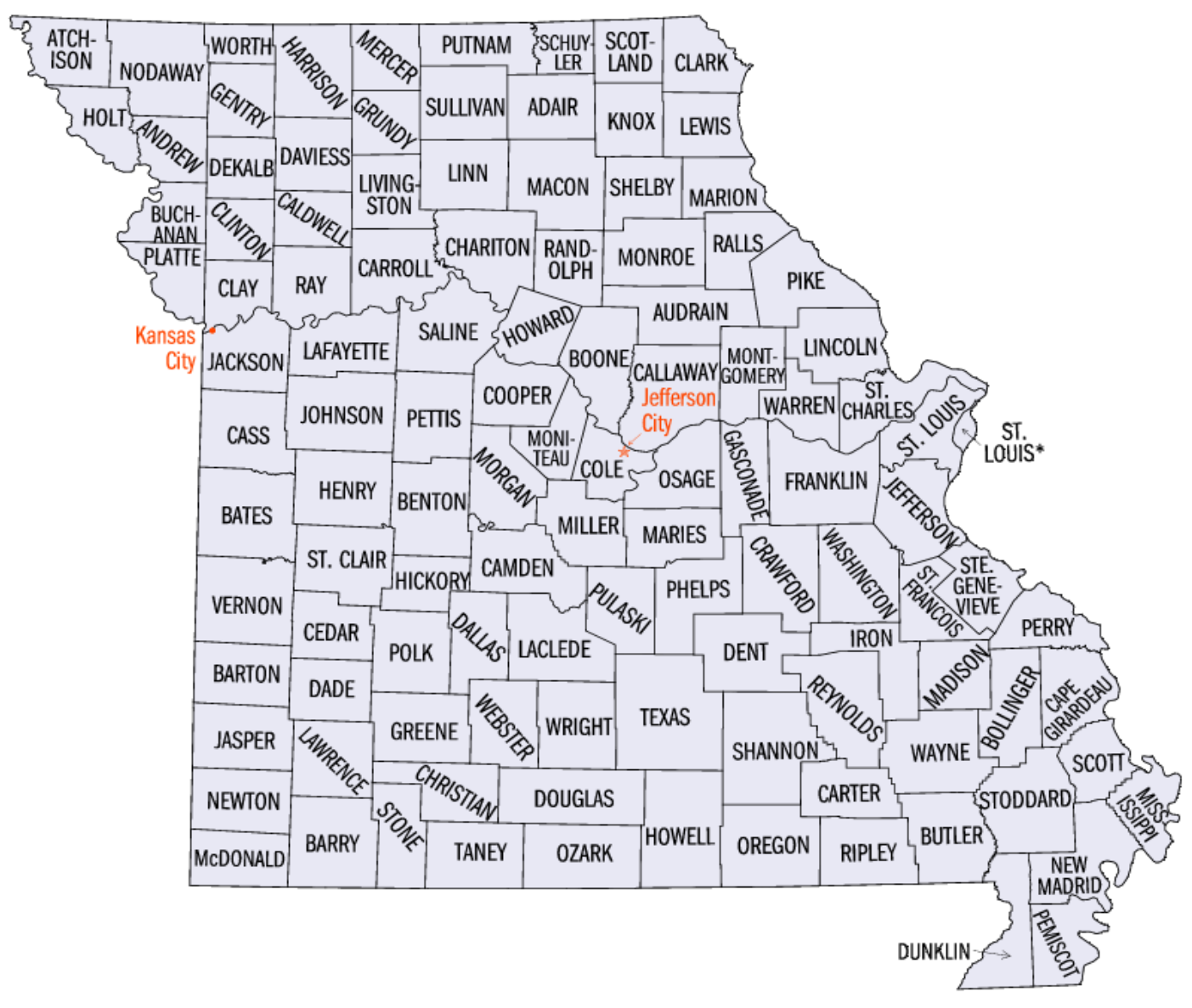

Figure 1: Map of Missouri Counties (Public Domain)

Though this project surveys the entire state of Missouri, there are specific localities that draw particular attention. These communities include St. Louis (St. Louis City/County) and Kansas City (Jackson County), the state's two largest metropolitan centers; Joplin (Jasper County), a burgeoning mining town in southwestern Missouri that boasted a population of roughly 30,000; St. Joseph (Buchanan County), a manufacturing hub of over 70,000 people that was quickly losing population and prominence to neighboring Kansas City; Columbia (Boone County), the home of the University of 
Missouri; Jefferson City (Cole County), the state's capitol and home to the all-black Lincoln University; and a key agricultural portion of the southeastern part of the state known as the Cotton Belt or "Bootheel" (Pemiscot, Dunklin, New Madrid, Mississippi, Stoddard, Scott, and Cape Girardeau counties). I focus on these locations for a few reasons. An examination of Ku Klux Klan affiliated newspapers identified these communities as active centers for the hooded order, especially Jasper and Buchanan counties. Also, just as these places underwent intense Klan activity, so too did they experience significant anti-Klan mobilization. This anti-Klan sentiment can be seen through local newspapers, political entities, and organizations that served these regions, including the NAACP, Knights of Columbus, and Jasper County Anti-Klan Association.

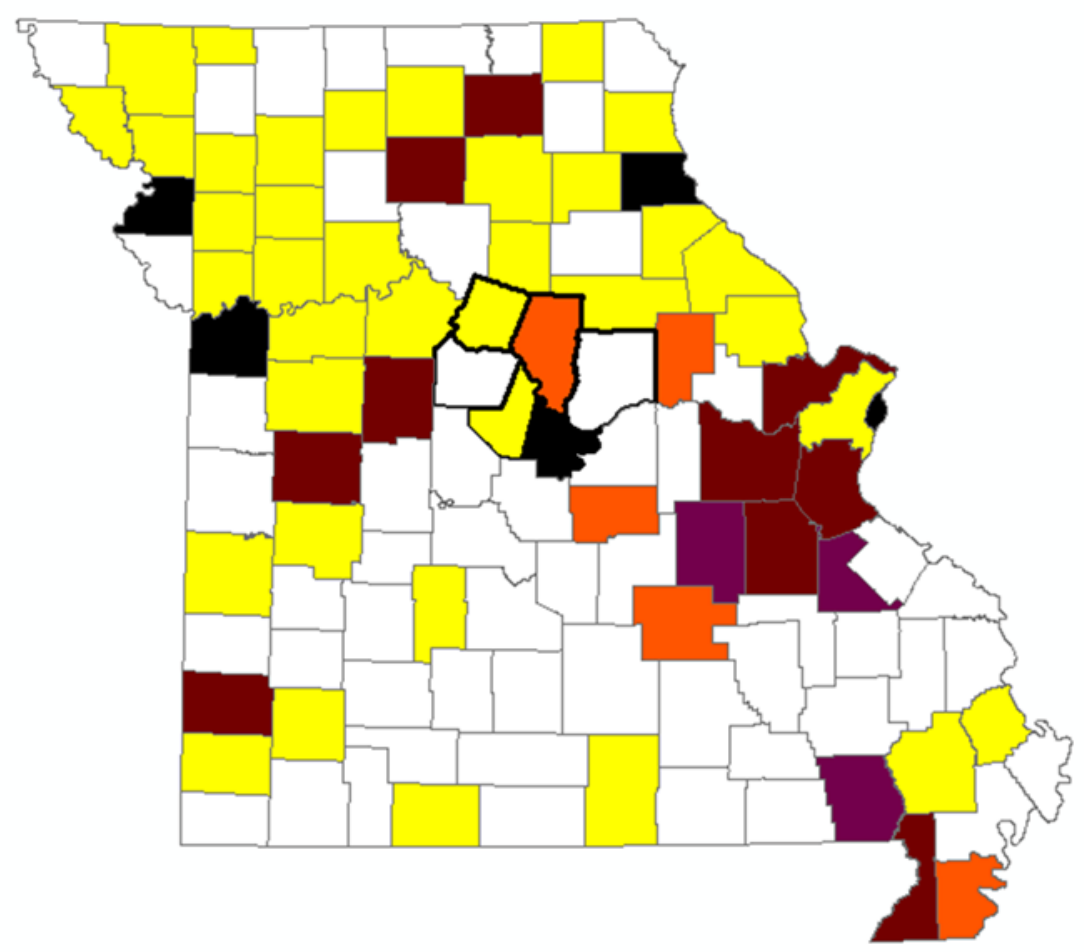

Figure 2: Klan activity in Missouri (July 1923-December 1924), by county, as documented in The Patriot, Missouri Fiery Cross, and Klan Kourier. White=0; Yellow=1-2; Orange=3-4; Maroon=5-6; Purple=7-9; Black=10+ (courtesy of the author) 
Additionally, these communities contained a level of racial, ethnic, and religious diversity that was relatively unmatched in other parts of the state. Though a vast majority of Missouri's black residents lived Kansas City and St. Louis, the total number living in the counties of this study accounted for nearly $70 \%$ of the state's African American population. ${ }^{22}$ The American Jewish Year Book reported that as of 1920 the state's Jewish population hovered around 80,000, including 60,000 in St. Louis, 12,000 in Kansas City, and 3,300 in St. Joseph. ${ }^{23}$ While the total Catholic population of the state is hard to ascertain, newspaper records and secondary materials suggest that each of the counties in this study had at least one Catholic parish. ${ }^{24}$ Out of an overall population of roughly 3.5 million, the African American, Catholic, Jewish, and foreign born populations of the various counties and communities of this project stood at over 350,000 by the end of World War I. ${ }^{25}$

Second, this study focuses on anti-Klan activism. While opposition to the Klan in Missouri is notable, anti-Klan activism occurred nationwide. However, the subject itself has largely been ignored in a vast majority of Klan scholarship. Though some scholars

\footnotetext{
${ }^{22}$ Clarence Lang, Grassroots at the Gateway: Class Politics and Black Freedom Struggle in St. Louis, 1936-75 (Ann Arbor: University of Michigan Press, 2009), 18. According to the 1920 Federal Census, Kansas City and St. Louis' African American populations stood at roughly 30,000 and 70,000 respectively. U.S. Bureau of the Census, Fourteenth Census of the United States: 1920, vol. 2: Population, 551-561.

${ }^{23}$ Harry Schneiderman, ed., The American Jewish Year Book 5681, September 13, 1920 to October 2, 1921, Volume 22 (Philadelphia: The Jewish Publication Society of America, 1920), 370-374.

${ }^{24}$ For resources that examine Catholicism in Missouri during the 1920s see William Barnaby Flaherty, Dream by the River: Two Centuries of Saint Louis Catholicism, 1766-1980 (St. Louis: River City publishers, 1981); This Far by Faith: A Popular History of the Catholic People of West and Northwest Missouri (Kansas City: Diocese of Kansas City-St. Joseph, 1992); Jeffrey R. Dorr, Race in St. Louis' Catholic Church: Discourse, Structures, and Segregation, 1873-1941 (MA Thesis, St. Louis University, 2015); Thomas Hornbeck, Historical Geography of the Catholic Church in Kansas City, Missouri: 1822-1930 (MA Thesis, University of Kansas, 2009).

${ }^{25}$ U.S. Bureau of the Census, Fourteenth Census of the United States: 1920, vol. 2: Population, 546-561.
} 
such as William Jenkins, Robert Goldberg, Leonard Moore, and Shawn Lay have devoted small portions of their research to anti-Klan activism, little has been written on the rise and fall of the second Ku Klux Klan from the perspective of those that fought so strongly against it. Over the past fifty years, most scholars who have examined the 1920s Klan have focused on regions of the United States and local communities where the Klan was successful in recruiting new members, gaining political power, and establishing its own vision of reform. Those that have referenced Klan opposition in their works tend to focus on the role of activists in initial opposition to the Klan when the group first arrived in a region or as a contributing force in accelerating the decline of the hooded order in the latter half of the decade. Ultimately, few scholars have sought to analyze areas where the Klan was not successful in its goals and little has been written on the role of anti-Klan activists in constantly, and effectively, challenging the organization throughout its second lifespan.

The work of historians David J. Goldberg and Shawn Lay, however, certainly reveal the significance of anti-Klan activism. ${ }^{26}$ According to Lay, "the Buffalo [New York] Klan experience suggests that racial, ethnic, and religious diversity, although it surely resulted in social tensions, may also have undermined the appeal of the Klan in certain communities. ${ }^{.27}$ An examination of locations where the Klan met sizable opposition could yield tremendous amounts of new scholarship that analyzes the variations of the Klan at a local level. Additionally, this new research could make a

\footnotetext{
${ }^{26}$ David J. Goldberg, "Unmasking the Ku Klux Klan: The Northern Movement Against the KKK, 1920-1925," Journal of American Ethnic History 15, no. 4 (Summer 1996), 32-48; Shawn Lay, Hooded Knights on the Niagara.

${ }^{27}$ Shawn Lay, Hooded Knights on the Niagara, 148.
} 
significant contribution to the understanding of early $20^{\text {th }}$ century activism undertaken by Catholics, Jews, and African Americans.

Finally, building upon an expansion of scholarship on early $20^{\text {th }}$ century activism, this project seeks to build upon on Jacqueline Dowd Hall’s "Long Civil Rights Movement" thesis. Published in 2005, Hall's article "The Long Civil Rights Movement and the Political Uses of the Past" in the Journal of American History argued that the civil rights movement could not be easily defined by a traditional narrative that existed between the Brown v. Board of Education ruling in 1954 and the Voting Rights Act of $1965 .^{28}$ Instead, as Hall and other scholars have shown, the fight for civil rights extends far beyond these well-known events. In looking at the anti-Klan activists of the 1920s, I argue that their efforts to stymie the growth of the hooded order served as the foundation for later efforts to combat the restrictions of a Jim Crow nation. Not every anti-Klan activist rose to later prominence, yet their work had a lasting impact on the civil rights movement.

${ }^{28}$ Jacquelyn Dowd Hall, "The Long Civil Rights Movement and the Political Uses of the Past," The Journal of American History 91, no. 4 (March 2005), 1233-1263. For resources on civil rights activism in Missouri after the 1920s see Priscilla A. Dowden-White, Groping Toward Democracy: African American Social Welfare Reform in St. Louis, 1910-1949 (Columbia: University of Missouri Press, 2011); Keona K. Ervin, Gateway to Equality: Black Women and the Struggle for Economic Justice in St. Louis (Lexington: University Press of Kentucky, 2017); Jeffrey D. Gonda, Unjust Deeds: The Restrictive Covenant Cases and the Making of the Civil Rights Movement (Chapel Hill: University of North Carolina Press, 2015); Colin Gordon, Mapping Decline: St. Louis and the Fate of the American City (Philadelphia: University of Pennsylvania Press, 2008); Lorenzo J. Greene, Gary R. Kremer, and Antonio F. Holland, Missouri's Black Heritage: Revised Edition (Columbia: University of Missouri Press, 1993); Gary R. Kremer, Race and Meaning: The African American Experience in Missouri. (Columbia: University of Missouri Press, 2016); Clarence Lang, Grassroots at the Gateway: Class Politics and Black Freedom Struggle in St. Louis, 1936-75 (Ann Arbor: University of Michigan Press, 2009); David Lucander, Winning the War for Democracy: The March on Washington Movement, $1941-1946$ (Urbana: University of Illinois Press, 2014); Jarod Roll, Spirit of Rebellion: Labor and Religion in the New Cotton South (Urbana: University of Illinois Press, 2010); Sherry Lamb Schirmer, A City Divided: The Racial Landscape of Kansas City, 1900-1960 (Columbia: University of Missouri Press, 2002). 
However, there must be a careful analysis of these anti-Klan figures. While some like George L. Vaughn, Roy Wilkins, C.A. Franklin, and J.E. Mitchell later served as noted civil rights leaders, others, particularly James A. Reed, did not have racial equality in mind when they openly fought the Klan. Put simply, anti-Klanism did not always equate to anti-racism and anti-bigotry. Just as anti-Klan activists came from diverse groups, so too did they have varying reasons for opposing the Invisible Empire, including community reform, political mobilization, and fears of lawlessness and violence. For African Americans, Catholics, and Jews, there were legitimate claims that the growth of the Klan replicated earlier instances of racial and religious intolerance. Yet, at the same time that anti-Klan activists were challenging an organization comprised of white supremacists, some of their own members embraced and defended key tenets of white supremacy. James Reed's role as one of Missouri's key anti-Klan politicians is an excellent example of this because though Catholics and Jews held him in high regard, his alleged support for racist policies at the state and federal level made him a notorious figure among the state's black population. As such, leaders in the African American community, many of whom worked just as hard as the senator to rid the state of the Klan, never fully trusted his anti-Klan sentiments, and actively worked to unseat Reed from Congress in order to install an anti-Klan as well as pro-civil rights replacement.

Perhaps most important in analyzing anti-Klan activism is understanding the limitations that existed in challenging the Invisible Empire. For all of their efforts to rebuke and reject the organization, anti-Klan activists were not able to fully stop the Klan's growth across the United States. At its height, the Klan claimed roughly five million members in forty-eight states, and the organization was quite successful in 
expanding the group to include women's and children's auxiliaries. Additionally, though activists did have some success in coordinating efforts between various groups - just as Walter White had advised Cora Carter - the grand plans for an interracial and interdenominational anti-Klan organization never materialized. Instead, what little headways occurred through alliance-building floundered on in-fighting and disagreements over the best way to challenge the Klan threat. Ultimately, these various anti-Klan groups opted to cheer each other on from the sidelines while waging individual battles against the Invisible Empire.

Despite the fractured nature of Klan opposition, and the ability of the hooded order to not only gain a large following but also to engrain its beliefs into mainstream American culture, anti-Klan activists in Missouri did achieve success in their efforts to fight the Klan. While one could certainly point to similar conclusions as other Klan studies where anti-Klan individuals rebuked the organization when it first arrived in certain communities and later emerged from the shadows once more as the Klan declined, this project demonstrates that those that fought the Klan did so on a daily basis.

Furthermore, though the Klan was able to wield considerable control in towns like Joplin and St. Joseph by the mid-1920s, anti-Klan groups continued to mobilize in an effort to overthrow the hooded order's influence in municipal affairs. An excellent example of this is the Jasper County Anti-Klan Association which failed repeatedly to unseat Klansympathetic politicians before eventually winning several key elections in 1926. Finally, and most importantly, the Klan was unable to translate its recruiting success in Missouri into substantial influence over state affairs because prominent leaders like Governor Arthur Hyde, Senator James A. Reed, and Congressman Harry Hawes ensured that both 
political parties rejected, or at the very least, marginalized the Klan. The end result was a state Klan that could claim a large membership but relatively little significant political power.

From the ancestors of slaveholders and enslaved people to Catholic workers, Protestant farmers, and Jewish business owners, the state of Missouri contained a diverse population by the 1920s. In 1921, Klan recruiters arrived at the periphery of the state and began to make inroads. Championing a message of white supremacy, Americanization, and honest law enforcement, these recruiters set out to win converts for their invisible empire. Many throughout the nation, and even in Missouri, would pledge their allegiance to the Klan. By the middle point of the decade, communities through the United States could boast of kleagles, kludds, exalted cyclopses, and grand wizards among their residents. The same could be said for communities throughout Missouri. Yet despite the best efforts of Klan officials, Missourians, through their anti-Klan activism, ensured that their counties and communities were "an arid field indeed" for the hooded knights of the Invisible Empire.

Though this is primarily a study of Missouri during the 1920s, this project pursues a chronological approach that begins in Missouri's earliest territorial days and continues to the dawn of the Great Depression. Chapter 1 surveys the legacy of white supremacy within the state, particularly the religious and racial intolerance that defined many of Missouri's most prominent political policies between 1821 and 1921. Additionally, the chapter makes clear that the anti-Klan activists of the 1920s were inspired to challenge bigotry in their communities by the actions of earlier generations. Chapter 2 examines the origins of the second Klan and the movement of the organization into Missouri 
around 1921. Coinciding with the growth of the Klan, a statewide anti-Klan press monitored the group's activities and put pressure on politicians and community leaders to speak out against it in an effort to stymie recruitment. Chapter 3 builds upon the importance of the anti-Klan press by analyzing how political pressure from newspapers pushed religious and secular organizations, particularly the Catholic Central Verein, Knights of Columbia, NAACP, Urban League, UNIA, and B'nai B'rith, to turn their attention toward the Klan in 1922 and 1923. This was particularly important in the reelection campaign of US Senator James Reed (MO-D) in 1922.

Chapter 4 highlights attempts by the Klan to separate itself from its violent history through an ambitious campaign aimed to promote female membership and political mobilization. Though the Klan had some success in these new endeavors, it was unable to convince many Missourians that the scourge of racial violence that plagued the state during the 1920s was not related to the organization's activities. Chapter 5 focuses on how the Klan's political mobilization at the local, state, and national level impact key elections in 1924, particularly the Missouri gubernatorial campaign. While achieving some success in Indiana, Colorado, and Oregon, Missourians largely rejected the Klan in many state level races. After experiencing only limited political success in the 1924 , the Klan endured a series of scandals featuring prominent members. Chapter 6 examines these scandals and shows how these events led to a substantial decrease in the organization's membership. Finally, Chapter 7 discusses how state Democrats utilized the Klan "issue" to bring African American voters into the party. This political realignment developed slowly and did not reach a majority until 1932. Nevertheless, efforts by Democrats to point out the failings of state Republicans, particularly their 
newfound lily-white/Klan-esque leanings and seeming aversion to civil rights, did factor into this eventual realignment. By the end of the decade, due to its own internal scandals as well as the prolonged efforts of anti-Klan activists to un-mask those associated with the Invisible Empire, the Klan's membership and influence nationwide significantly declined. 


\section{Chapter 1: The Dead Men}

As dusk fell upon Jefferson City, a crowd of roughly twenty thousand fell silent on the grounds of the state capitol building. The silence of the chilly October air was shattered as Battery A, an artillery unit based in St. Louis, unleashed a twenty-four gun salute. The sound rippled through the town and across the Missouri River into nearby Callaway County. When the artillery stopped, Forrest C. Donnell, a young attorney who would later serve as a governor and US Senator for Missouri, told the crowd that the evening's festivities would feature a pageant dedicated to the state's history. With the close of his introduction, a collection of electric light towers turned on to reveal a large stage temporarily built over the steps of the state capitol building. The crowd responded with wonder to the illumination of the stage and the large granite capitol building in the background. ${ }^{1}$

The festivities in Jefferson City were organized to celebrate the dedication of a new capitol building completed in 1924. Its predecessor burned down in 1911, and the new granite structure had been slowly rising over the subsequent years. To honor the occasion, state officials arranged for a series of events on October 6, 1924 to document the state's history. Drawing several prominent dignitaries including US Senator Seldon Spencer, Assistant Secretary of War Dwight F. Davis, and four former governors, the dedication day featured a parade that circled the city's business district as well as a

\footnotetext{
${ }^{1}$ St. Louis Post-Dispatch, 7 October 1924; St. Louis Star, 7 October 1924.
} 
collection of speeches from local and state officials. ${ }^{2}$ In the evening, with the crowd amassing on the capitol grounds, the pageant, featuring over two thousand participants, took center stage and presented "the building of a commonwealth, Missouri, mother of the West."

Set in four epochs, the pageant centered on the state's history. It opened with a re-creation of early explorations of what would become Missouri, including Hernando De Soto's discovery of the Mississippi River and the travels of Jacques Marquette and Louis Joliet. The actor portraying Marquette then built a cross on the stage to symbolize the founding of St. Genevieve, the oldest town within the present borders of Missouri. Daniel Boone's movement west followed Marquette's cross planting and depicted subsequent battles between settlers and Native Americans. The arrival of settlers representing the United States drew the loudest response from the crowd, according to the press, as the flags of Spain and France were lowered and replaced with the American flag. As the pageant's history drew closer and closer to modern day, including retellings of the Civil War, Spanish-American War, and Mark Twain's literary career, storm clouds appeared on the horizon. When the third epoch paused to honor Missourians killed during World War I, the skies opened up, the rain came, and the audience rushed for cover. Fearing the weather would ruin the festivities; organizers abruptly ended the pageant and called for the grand finale. From barges on the Missouri River, fireworks

\footnotetext{
${ }^{2}$ St. Louis Post-Dispatch, 6 October 1924, 7 October 1924; St. Louis Star, 6 October 1924, 7 October 1924.

${ }^{3}$ St. Louis Post-Dispatch, 6 October 1924, 7 October 1924; St. Louis Star, 6 October 1924, 7 October 1924.
} 
shot into the air, and "their many colored lights mingling with the flash of lightning in an angry sky."

The history of Missouri portrayed by organizers was largely a whitewashed version of events. Though they included a theatrical version of the Missouri Compromise and the Civil War, pageant officials declined to acknowledge the state's slaveholding past. Instead, a retelling of the Battle of Wilson's Creek ended with "Missouri and her attendants [clasping] the hands of the blue and gray soldiers." ${ }^{5}$ There was no mention of the African American soldiers who enlisted to protect the state, nor a reference to the use of slave labor in the development of Missouri's early agricultural economy. This omission was not lost on the St. Louis Argus, who denounced the segregated nature of the festivities, including separate seating accommodations, as "an insult to the colored people of the state." 6

Additionally, though the contributions of Catholics in Missouri received attention in the pageant, rumors circulated in the press that John P. Gordon, a prominent Jefferson City Klansman and member of the capitol dedication committee, objected to the scene depicting Marquette's cross planting. In an awkward turn of events, Gordon had to introduce Catholic Archbishop John J. Glennon for the opening invocation. Given the opportunity to speak, and no doubt aware of Gordon's reputation, Glennon called on God to bless the capitol building so that corruption might never be found within its walls and

${ }^{4}$ St. Louis Post-Dispatch, 6 October 1924, 7 October 1924; St. Louis Star, 6 October 1924, 7 October 1924.

${ }^{5}$ St. Louis Post-Dispatch, 7 October 1924.

${ }^{6}$ St. Louis Argus, 10 October 1924. 
"the black clouds of bigotry might never darken its dome." Nevertheless, the Klan made sure it's presence was felt in the capitol city with recruiting flyers plastered throughout town, including on the front of the pageant stage, advertising an upcoming "patriotic" rally and a food stand run by the group along the parade route. ${ }^{8}$

Missouri's history has long been a contested space. While pageant officials in 1924 preferred a more whitewashed version of events, contemporary scholarship has revealed the diversity that existed through Missouri's long, and complicated, history. A detailed examination of the legacy of white supremacy within the state helps us to understand the rise of the second Ku Klux Klan in Missouri. This narrative did not begin with the first fiery crosses burned within the state in 1921, but can be traced back to Missouri's origin as a territory that was coveted and controlled by various nations. The early slave laws that existed in territorial Missouri served as the beginning point for repressive policies that relegated people of color to second-class citizenship and influenced racial violence that plagued the state at various points in its history. Additionally, though they were not overly successful, private organizations, secret societies, and nativist politicians also tried to restrict the rights of foreign-born, Jewish, and Catholic residents of the state. As much as modern day Missourians might prefer to assume that fringe individuals and organizations undertook such activities, racial and religious intolerance were central to many of the policies which shaped the state's development. This origin story helps explain the rise and fall of Missouri's Invisible Empire.

\footnotetext{
${ }^{7}$ St. Louis Post-Dispatch, 7 October 1924.

${ }^{8}$ St. Louis Post-Dispatch, 7 October 1924.
} 
Meanwhile, some Missourians, particularly African Americans and German Catholics, attempted to foster political reconciliation, religious toleration, and racial harmony during the $19^{\text {th }}$ and early $20^{\text {th }}$ centuries. While far from dominating state politics, their activism nevertheless pushed back against attempts by bigots and nativists to restrict their participation in shaping public policy. At the same time, these marginalized groups continually reminded their fellow Missourians that they deserved the full rights and protections of citizenship. Their political activism served as a rallying cry against oppression. In the end, these early efforts to fight racial and religious intolerance within the state deeply influenced later activists, politicians, and common citizens who challenged the Invisible Empire during the 1920s.

Even before the Louisiana Purchase transferred control of the land that would become Missouri to the United States, a steady stream of settlers called the region their home. Indigenous tribes, particularly the Osage, predated white settlement. The arrival of later French and Spanish settlers brought conflict, but also cooperation, to the region known as Illinois Country and Upper Louisiana. While early settlers, particularly fur traders, tried to develop close business and kinship relations with the tribes of the region, the new residents that arrived in the $19^{\text {th }}$ century preferred a plan of ethnic cleansing and "Indian removal." Backed by prominent politicians like Senator Thomas Hart Benton, early nineteenth century Missourians demanded that state and federal officials remove native tribes from the state so as to gain access to valuable natural resources and open up larger areas for white settlement. As such, Missouri served not only as a crossing for 
Native Americans from the Southeast headed to Indian Territory by way of the Trail of Tears, but also as a location of expulsion for tribes who had called the land their home. ${ }^{9}$ With the dawn of the nineteenth century, and as a result of the Louisiana Purchase, the population of Missouri steadily increased. From the South and East came settlers from Virginia, Tennessee, North Carolina, and Kentucky. Most of these Upper South migrants found new homes along the region's two great rivers, the Mississippi and Missouri. While communities like St. Genevieve had dominated colonial life in eighteenth century Missouri, St. Louis wrested away the mantle of "most important city" by the early nineteenth century. In addition to St. Louis, communities along the primary waterways, particularly St. Charles, Franklin, Hannibal, and Cape Girardeau, also held great importance in early Missouri. ${ }^{10}$

After a period of substantial growth following the Louisiana Purchase, Missouri was on the verge of statehood. However, its admission was far from a relaxed affair. When territorial representative John Scott submitted Missouri's petition for statehood to Congress in 1818, the issue of Alabama's admission as a state was nearing its resolution. After Alabama obtained statehood in 1819, the number of free and slave states were evenly distributed at eleven each. Bringing in Missouri as a twelfth slave state would

\footnotetext{
${ }^{9}$ Perry McCandless, A History of Missouri: Volume II, 1820-1860 (Columbia: University of Missouri Press, 1972), 18, 22-33, 53-55; Stephen Aron, American Confluence: The Missouri Frontier from Borderland to Border State (Bloomington: Indiana University Press, 2009), 1-115, 139-147, 203-216.

${ }^{10}$ Kristen Epps, Slavery on the Periphery: The Kansas-Missouri Border in the Antebellum and Civil War Eras. (Athens: University of Georgia Press, 2016), 14; Greene, Kremer, and Holland, Missouri's Black Heritage, 27; McCandless, A History of Missouri: Volume II, 33-37; Diane Mutti Burke, On Slavery's Border: Missouri's Small Slaveholding Households, 1815-1865 (Athens: University of Georgia Press, 2010), 24-51; Aron, American Confluence, 158-160, 164-174, 197-198; Aaron Astor, Rebels on the Border: Civil War, Emancipation, and the Reconstruction of Kentucky and Missouri (Baton Rouge: Louisiana State University Press, 2012), 15-19.
} 
instantly throw off the balance. As such, Missouri had to wait. In an effort to appease both sides of the slavery issue, Congressman James Talmadge of New York offered a compromise whereby Missouri would be admitted as a slave state, but from the moment of its admission slaves could not enter the territory and all slaves born after statehood were to be freed at the age of twenty-five. Talmadge's proposal passed the House of Representatives, but met its death at the hands of the Senate. The issue of Missouri, what Thomas Jefferson called a "fire bell in the night," remained unresolved. ${ }^{11}$

While the issue of slavery would dominate Missouri politics until the Civil War, its statehood status was resolved by the early 1820s. Under the Missouri Compromise, Maine gained admittance as a free state and Missouri entered into the Union as a slave state. This decision allowed for the continued balance of free and slave states. However, Congress also moved to prevent further concerns over the free/slave divide by defining Missouri's southern border, on the 36,30 parallel, as the line of demarcation for slavery. With the exception of Missouri, slavery was prohibited in all Louisiana Purchase land north of that line. The land below Missouri's border was to be given over to slave interests if new states opted for the institution in their constitutions. With a compromise reached, President James Monroe granted Missouri statehood on August 10, 1821. ${ }^{12}$ With the addition of the Platte Purchase in 1837, Missouri's present-day state boundaries were finally completed, and the settlement of large portions of the state soon followed. ${ }^{13}$

${ }^{11}$ Greene, Kremer, and Holland, Missouri's Black Heritage, 22-24; Epps, Slavery on the Periphery, 20; McCandless, A History of Missouri: Volume II, 2-3; Aron, American Confluence, 177-181.

${ }^{12}$ Greene, Kremer, and Holland, Missouri's Black Heritage, 22-24; Epps, Slavery on the Periphery, 20; Aron, American Confluence, 180-184.

${ }^{13}$ Epps, Slavery on the Periphery, 26-30; Aron, American Confluence, 229-231. 
The arrival of ever increasing numbers of Upper South residents in these early years had a major impact on the political, economic, social, and cultural development of Missouri. With roughly $60 \%$ of new state residents coming from the American South in the early antebellum period, it was not long before Missouri began to replicate her southern sister states. ${ }^{14}$ However, the slave system that developed in Missouri was starkly different from the traditional plantation south for two main reasons. First, while some slave owners did own substantial wealth and hold key positions in state government, the large plantation structure of the Deep South did not occur in Missouri. Though there were a few slave holders who owned enough slaves to be comparable to the larger plantations of the South, the majority of Missouri slave owners held fewer than twenty slaves. ${ }^{15}$ Second, Missouri did not produce the same sought after cash crops as a majority of the South. While portions of southeastern Missouri eventually harvested cotton, its kingdom did not extend very far into the state. Instead, enslaved people in Missouri were more likely to labor with tobacco, hemp, corn, oats, and wheat. ${ }^{16}$

This small-scale slavery, as contemporary scholars have defined it, dominated Missouri's Mississippi River valley, and the central portion of the state bordering the Missouri River known as "Little Dixie." In these regions, slave owners were more likely to work alongside enslaved people in the fields, though mutual understanding and respect

\footnotetext{
${ }^{14}$ Burke, On Slavery's Border, 25.

${ }^{15}$ Epps, Slavery on the Periphery, 16, 46, 57-65; Greene, Kremer, and Holland, Missouri's Black Heritage, 20-28; Burke, On Slavery's Border, 48-51; Astor, Rebels on the Border, 19-32.

${ }^{16}$ Epps, Slavery on the Periphery, 49-52, 57-65; Greene, Kremer, and Holland, Missouri's Black Heritage, 25; Burke, On Slavery's Border, 27-28; Astor, Rebels on the Border, 22; McCandless, A History of Missouri: Volume II, 47-49; Aron, American Confluence, 174-175, 198.
} 
were far from common. ${ }^{17}$ When the field or domestic work was completed, slave owners frequently hired out enslaved people to nearby farms or employers. Just as it was not uncommon to see the state's agricultural fields tilled by enslaved people, so too was it a common sight to witness slaves working on construction projects such as building railroad lines or on the docks assisting riverboat commerce. ${ }^{18}$ The close proximity of work between master and slave may have lessened the chance of a revolt, yet Missouri's enslaved population found ways to resist whenever possible. ${ }^{19}$ The most famous example of resistance in antebellum Missouri involved a young female slave named Celia who repeatedly tried to fight off the sexual advances of her owner Robert Newsom. When he attempted to sexually assault her once more in 1855, Celia killed Newsom and disposed of his corpse before being arrested and executed for her role in his murder. ${ }^{20}$

With a society built by, and upon, slavery, Missouri's first slave laws predated statehood. Despite the region's shifting territorial claims between the French, Spanish, and finally the Americans, slave codes largely derived from France's Code Noir.

${ }^{17}$ Epps, Slavery on the Periphery, 16, 57-65; Greene, Kremer, and Holland, Missouri's Black Heritage, 8-13; Astor, Rebels on the Border, 19-32. For a detailed study of small-slaveholding in Missouri see Diane Mutti Burke, On Slavery's Border: Missouri's Small-Slaveholding Households, 1815-1865 (Athens: University of Georgia Press, 2010).

${ }^{18}$ Greene, Kremer, and Holland, Missouri's Black Heritage, 25-26; Burke, On Slavery's Border, 107-118; Astor, Rebels on the Border, 27-28; Aron, American Confluence, 175. When the first slaves arrived in upper portion of French controlled Louisiana, they tended to labor in agricultural work. However, the profit attainable through lead and silver mining, particularly around Mine La Motte, also added to the necessity of slave labor. Initially, the region's slaves included both Afro-Caribbean and Native American slaves, but the enslavement of Native Americans was lessened over time until the Spanish prohibited the practice in the 1760s. Spanish control also brought about the end of French efforts to prevent slaves from buying their own freedom. Greene, Kremer, and Holland, Missouri's Black Heritage, 8-10, 17.

${ }^{19}$ Greene, Kremer, and Holland, Missouri's Black Heritage, 43-44.

${ }^{20}$ Greene, Kremer, and Holland, Missouri's Black Heritage, 48-49. For perhaps the best account of Celia's life and death see Melton Alonza McLaurin, Celia, A Slave (Athens: University of Georgia Press, 1991). 
Established in 1685, the Code Noir laid out the rights given to both slave and slave master. A slave owner was required to provide slaves with adequate care, allow them time for recreation on Sundays or holidays, and prevent, if possible, the breakup of families through sale. Additionally, the Code Noir allowed slaves to sue their masters if they felt these rights were denied. However, due to the isolation of the upper Louisiana Territory and a lack of enforcement, the rights offered to enslaved people through the Code Noir were more of a recommendation than reality. ${ }^{21}$

When it came to a master's control over their slaves, the rights of property were more of a reality. Owners controlled every aspect of a slave's body from the materials they produced and sold to the person they married. For female slaves this was especially devastating considering the sexually exploitative demands of an owner. All of this fell under the permission of the master, and resistance brought punishment. While the Code Noir prohibited masters from torturing or killing slaves without definite reason, the laws allowed for whippings if a slave became incorrigible and the death penalty if an enslaved person assaulted a member of the master's family. ${ }^{22}$ Compared to their enslaved brethren, free people of color enjoyed many more protections within the Code Noir. Under the law, they held the same rights and privileges as other French citizens. Yet, the specter of inferiority and slavery always hung at their backs. Free people of color were to

\footnotetext{
${ }^{21}$ Greene, Kremer, and Holland, Missouri's Black Heritage, 8-13; Burke, On Slavery's Border, 21; Aron, American Confluence, 47-48.

${ }^{22}$ Greene, Kremer, and Holland, Missouri's Black Heritage, 11-13; Burke, On Slavery's Border, 21; Aron, American Confluence, 47-48.
} 
display reverence to whites, particularly their former masters, and faced re-enslavement for crimes ranging from theft to aiding escaped slaves. ${ }^{23}$

With the approval of the Louisiana Purchase in 1803, the United States soon acquired the territory that contained Missouri. Though a frontier controlled by indigenous tribes, and largely uninhabited by white settlers; Missouri's territorial government moved quickly to protect the property, including slaves, held by those within the region. In the years before statehood, laws, many modeled after similar legislation in Virginia and Kentucky, established a racial hierarchy between whites and blacks. ${ }^{24}$ Many of these territorial laws incorporated elements of the Code Noir, but they also added new restrictions on accessibility to property and the court system for both enslaved and free people of color. Perhaps most striking, the new laws defined anyone with one quarter of "Negro blood" as black. ${ }^{25}$

Missouri's geographic location held significant importance in the establishment of strict slave laws. Though the state protected the "peculiar institution," neighboring states, including Illinois and Iowa, as well as Indian Territory (Kansas would later be carved out of this region) left Missouri bordered on three sides by "free" land. As such, it was much easier for those held in bondage to escape compared to other slave states. ${ }^{26}$ The laws designed to prevent runaways placed responsibility for the attempt as much in

\footnotetext{
${ }^{23}$ Greene, Kremer, and Holland, Missouri's Black Heritage, 15; Burke, On Slavery's Border, 21; Aron, American Confluence, 47-48.

${ }^{24}$ Epps, Slavery on the Periphery, 66-67, 122; Burke, On Slavery's Border, 23-24.

${ }^{25}$ Greene, Kremer, and Holland, Missouri's Black Heritage, 21; Burke, On Slavery's Border, 23-24.

${ }^{26}$ Epps, Slavery on the Periphery, 80-84; Burke, On Slavery's Border, 28; Aron, American Confluence, 216.
} 
the hands of those aiding the enslaved person as in the slaves themselves. If a slave was found without a pass, a person was required to transport them to the nearest Justice of the Peace and post advertisements about the capture in local newspapers until the owner was located. Since river travel dominated transportation in the antebellum period, boat captains were fined for transporting slaves without the owner's permission. ${ }^{27}$ Perhaps the most significant piece of legislation, which greatly expanded existing slave patrols, was an 1849 law aimed at runaway slaves. Predating the federal Fugitive Slave Law of 1850, the Missouri version allowed the governor to call upon law enforcement officials in other states and territories to aid in the capture of an escaped slave if they lived in that location but was proven to be the property of a Missouri resident. ${ }^{28}$

Though the state's slave laws restricted mobility and freedom, they also bestowed some limited benefits on enslaved people. As the famous Dred Scott decision demonstrates, slaves within the state could sue for their freedom if it was proven that they had been held illegally. When these types of cases made it on the court docket, slaves had the right to an attorney and a jury trial. However, slaves could not testify in court against a white person nor would their trial by presented before a jury of their peers. Additionally, despite their access to the courts, enslaved people could not hold property, congregate together, or obtain a marriage license without their owner's consent. Even if their owner did consent, state law prohibited slaves from being sold alcohol or receiving an education. In situations of assault, harassment, or rape, slaves could not fight back against a white person, even in self-defense. Many of these laws pertained to free blacks

\footnotetext{
${ }^{27}$ Epps, Slavery on the Periphery, 122-123.

${ }^{28}$ Epps, Slavery on the Periphery, 81.
} 
as well, and by the 1850 s, Missouri's General Assembly prohibited the movement of free blacks into the state and made it illegal for the legislature to pass an emancipation law unless it offered compensation for slaveholders. ${ }^{29}$

While slaveholding Missourians may have asserted that stricter laws were needed to regulate the activities of enslaved people as well as free blacks, they were also concerned about the increasing non-native population within the state, particularly Germans and Irish as well as Mormons. No doubt influenced by prejudice against ethnic and racial groups deemed "inferior," some Missourians detested the arriving settlers for their opposition to slavery. ${ }^{30}$ Led by Joseph Smith, Mormons settled in western Missouri in the $1830 \mathrm{~s}$, but their religious practices and opposition to slavery brought a violent reaction from their new neighbors who utilized a state sanctioned Mormon War to drive them into Illinois and eventually Utah. ${ }^{31}$ Unlike the Mormons, Germans, many of whom were inspired by the travel writings of Gottfried Duden, flocked to the state by the thousands between 1820 and 1850 and established a firm foundation along the Missouri River Valley. ${ }^{32}$ They were soon joined by brethren from the old country attempting to escape the European revolutions of 1848, as well as increasing numbers of Irish fleeing

\footnotetext{
${ }^{29}$ Epps, Slavery on the Periphery, 66-67, 122-123; Aron, American Confluence, 216-218, 238, $242-$
} 243.

${ }^{30}$ Epps, Slavery on the Periphery, 80-82; Alison Clark Efford, German Immigrants, Race, and Citizenship in the Civil War Era (New York: Cambridge University Press, 2013), 56-57, 73, 92.

${ }^{31}$ For resources on the Mormon War in Missouri see Stephen C. LeSueur, The 1838 Mormon War in Missouri (Columbia: University of Missouri Press, 1987); Brandon G. Kinney, The Mormon War: Zion and the Missouri Extermination Order of 1838 (Yardley: Westholme Publishing, 2011).

32 McCandless, A History of Missouri: Volume II, 38-39; Frederick E. Brock, The American Party in Missouri, 1854-1860 (Master's Thesis, University of Missouri-Columbia, 1949), 20-21; Astor, Rebels on the Border, 18-19; Aron, American Confluence, 202-203. 
the devastation of the potato famine. ${ }^{33}$ By the 1850 s, Missouri's foreign born population stood at roughly $160,000 .{ }^{34}$ From their positions of power amongst small slaveholding farms of the state, pro-slavery adherents increasingly worried that a day might come when the foreign born population would vote slavery down by a popular referendum. ${ }^{35}$ In addition to fearing increased anti-slavery sentiments, some Missourians also expressed contempt for the Catholic faith practiced by many foreign born immigrants. Catholicism, however, was far from new in Missouri. During the periods of French and Spanish control, Missouri was a predominately Catholic territory, and for a time banned Protestant worship. With the Louisiana Purchase, the region's rigid Catholic boundaries disappeared in favor of open religious toleration. Yet, communities like St. Louis and St. Genevieve continued to have large Catholic populations. ${ }^{36}$ As the $19^{\text {th }}$ century wore on, more and more Catholic immigrants arrived in the state and set up communities, particularly on the south side of the Missouri River between Jefferson City and St. Louis. ${ }^{37}$

This substantial Catholic growth can be attributed to priests stationed throughout the river region. Perhaps no one was more important for the development of Missouri

${ }^{33}$ McCandless, A History of Missouri: Volume II, 38-41; Brock, The American Party in Missouri, 2022; Astor, Rebels on the Border, 18-19.

${ }^{34}$ McCandless, A History of Missouri: Volume II, 38-39; Brock, The American Party in Missouri, 2223; Aron, American Confluence, 237-238.

${ }^{35}$ Epps, Slavery on the Periphery, 80-82; Efford, German Immigrants, Race, and Citizenship in the Civil War Era, 56-57, 73, 92.

${ }^{36}$ James Neal Primm, Lion of the Valley: St. Louis, Missouri, 1764-1980, Third Edition (St. Louis: Missouri Historical Society Press, 1998), 91-94; Brock, The American Party in Missouri, 17-19.

${ }^{37}$ Primm, Lion of the Valley, 143-144, 164, 314-315; McCandless, A History of Missouri: Volume II, 39-41; Brock, The American Party in Missouri, 18-22; Efford, German Immigrants, Race, and Citizenship in the Civil War Era, 34. 
Catholicism than Father Ferdinand Benedictus Maria Gislenus Helias. Remembered locally as Father Helias, the young Jesuit arrived in central Missouri in 1838. He was not the first priest to lead mass in the state, but he was one of the first Catholic leaders to stay in the region long-term. Helias was born to a noble family known as d'Huddeghem in Ghent, Belgium in 1796. He entered the priesthood under the Jesuit order in the early $19^{\text {th }}$ century and was eventually assigned to mission work in the United States in the 1830s. Initially setting up his mission work in Westphalia, Missouri, Helias soon traveled throughout the Missouri River region in the name of Catholicism. His regular circuit took him through the present-day counties of Osage, Cole, Callaway, Boone, Cooper, Gasconade, and Pettis. Most of this travel he did on horseback, though he was known to occasionally use river transportation. Father Joseph H. Schmidt, an early $20^{\text {th }}$ century Catholic priest, estimated that Helias attended to roughly 3,600 Catholics in central Missouri on his regular circuit. ${ }^{38}$

In 1842, Helias relocated to Taos, Missouri, only a few miles northwest of Westphalia. From his new home, Helias worked quickly to make the small town into the center of Catholic work in the state. The move also allowed him to be closer to the state capitol of Jefferson City, roughly ten miles from Taos. His vow of poverty prevented Father Helias from enjoying the burgeoning riches of the region, yet his connection to his far reaching congregations allowed the priest to wield significant power. However, Helias showed little interest in using this power for anything but continuing to grow the state's Catholic communities. By the 1840s, other priests joined Helias in an effort to

38 Joseph H. Schmidt, "Recollections of the First Catholic Missions in Central Missouri," Missouri Historical Review 5, no. 2 (January 1911), 83-87, 89-90. 
better facilitate the needs of the expanding Catholic population. While these new priests eased the burden, Helias continued to serve his congregants in Taos and surrounding communities for the rest of his life, including the construction of several schools to provide parochial education. He died in 1874 at the age of 78 and was buried in his beloved Taos. ${ }^{39}$

While it is unknown if Father Helias personally experienced nativism during his time in central Missouri, he did live in a part of the state that embraced the American Party in the 1850s. In his recollection of Catholicism in central Missouri, Father Joseph Schmidt acknowledged that some priests did encounter nativist sentiments in western portions of Missouri. ${ }^{40}$ Before this brand of nativism shifted into political activism, it primarily functioned as a social and violent response to the arrival of ever-increasing numbers of European immigrants in the 1820s and 1830s. Scholars, particularly Tyler Anbinder, have noted the popularity of secret nativist societies as well as anti-Catholic pamphlets, especially the alleged convent narratives of women like Maria Monk, during the antebellum period. ${ }^{41}$ These years also witnessed several nativist riots in prominent American cities. ${ }^{42}$ With the rise of groups like the Order of Americans and the Order of the Star Spangled Banner, combined with a fiery antipathy for Catholic immigrants

\footnotetext{
${ }^{39}$ Schmidt, "Recollections of the First Catholic Missions in Central Missouri," 83-92.

${ }^{40}$ Schmidt, "Recollections of the First Catholic Missions in Central Missouri," 90.

41 Tyler Anbinder, Nativism and Slavery: The Northern Known Nothings and the Politics of the 1850s (Oxford: Oxford University Press, 1992), 9-14; Brock, The American Party in Missouri, 3-4, 23-27; William Barnaby Faherty, "Nativism and Midwestern Education: The Experience of St. Louis University, 1832-1856," History of Education Quarterly 8, no. 4 (Winter, 1968), 447-458.

${ }^{42}$ Anbinder, Nativism and Slavery, 12, 28-29; Primm, Lion of the Valley, 166-169; Faherty, "Nativism and Midwestern Education," 447-458.
} 
among some American Protestants, it was not long before the nativism of the antebellum period turned into a political movement. ${ }^{43}$

Some of the earliest "Native American" parties in Missouri met with only limited success in the 1840 s. While they were able to influence municipal politics, these parties could not break through at the state or national level. ${ }^{44}$ This changed, however, with the growing alliance between the Whigs and the American Party. Though it was far from a perfect match, as the budding relationship was tenuous at best, both organizations experienced greater success as a united coalition, particularly in St. Louis' municipal elections. ${ }^{45}$ In addition to city level offices, the alliance's voting power also put party men in the mayor's seat with the election of Peter G. Camden in 1846, Luther Kennett in 1850-1852, and Washington King in $1855 .{ }^{46}$ The success of Kennett, perhaps the most prominent member of the Whig/American alliance in Missouri, came from his close relationship with local nativists as well as his surprising alliance with a portion of the city's Catholic Whigs. ${ }^{47}$ Kennett would go on to win election to Congress in 1854 , beating out Thomas Hart Benton and future governor Trusten Polk in a campaign that

\footnotetext{
${ }^{43}$ Anbinder, Nativism and Slavery, 9-21; Brock, The American Party in Missouri, 6-8, 23-27.

${ }^{44}$ Brock, The American Party in Missouri, 3-8, 23-27.

45 Primm, Lion of the Valley, 164-169; Brock, The American Party in Missouri, 33-47, 53-64

46 Primm, Lion of the Valley, 164-172; Brock, The American Party in Missouri, 25-27.

47 Primm, Lion of the Valley, 164-172; Brock, The American Party in Missouri, 25-27.
} 
saw St. Louis plunged into rioting between Catholics and nativists. ${ }^{48} \mathrm{He}$ lost his reelection bid in $1856 .{ }^{49}$

One of the main reasons that the Whigs aligned with the growing American Party was because, as a political entity, the Whigs were in decline by the 1850 s due to internal splintering over the issue of slavery. ${ }^{50}$ Desperate to remain politically viable and hoping to unseat the Democratic Party which was also teetering on an impending fracture, Missouri Whigs pushed quickly to not only embrace the American Party but to control it. ${ }^{51}$ With the growth of their alliance, Whigs and Americans felt confident that they would control the Missouri General Assembly by the mid-1850s. Yet, while holding a numerical advantage over the splintered Democrats which had broken into Benton and anti-Benton factions due to the "free soil" position of prominent Congressman Thomas Hart Benton, Whigs still worried that the issue of slavery would continue to divide the nation as well as the state. ${ }^{52}$ Looking to appease both pro-slavery and unionist voters, the Whigs moved more towards the American Party as the decade progressed. Though it was supposed to be a secret society with political ambitions, the American Party in Missouri, also known as the Know Nothings because members were supposed to respond "I know

48 McCandless, A History of Missouri: Volume II, 265-267; Primm, Lion of the Valley, 169-172; Brock, The American Party in Missouri, 35-37; John C. Schneider, "Riot and Reaction in St. Louis, 1854 1856, " Missouri Historical Review 68, no. 2 (1974) 171-185.

${ }^{49}$ Brock, The American Party in Missouri, 90-106.

${ }^{50}$ Brock, The American Party in Missouri, 8, 64.

${ }^{51}$ Brock, The American Party in Missouri, 68-85.

${ }^{52}$ Brock, The American Party in Missouri, 8-17. 
nothing" when asked about the group, was far from secretive. ${ }^{53}$ The growing alliance with the Whigs was an open secret and several prominent Whigs expressed support for the American Party. ${ }^{54}$

According to historian Perry McCandless, despite the fact that the larger Know Nothing movement held ties to nativism and bigotry, the alliance between the American and Whig parties in Missouri was built more around the southern wing of the American Party which promoted the perseverance of the Union and the protection of slavery instead of overt religious intolerance. ${ }^{55}$ When the American Party held its state convention in Boone County in 1856, Whigs dominated the proceedings. The convention moved quickly to pass a party platform that supported the federal Fugitive Slave Law and spoke out against Congress' previous attempts to regulate slavery in states and territories. While the Whigs within the alliance may have favored few limitations on slavery, state Know Nothings split over the issue. ${ }^{56}$

In an attempt to win support from Know Nothing members concerned over the slavery issue, and strike back against anti-Bentonites, Benton Democrats, particularly B. Gratz Brown and Francis P. Blair Jr., lobbied American Party members to form a political coalition aimed at rejecting southern Democrats. ${ }^{57}$ This coalition failed to

${ }^{53}$ Brock, The American Party in Missouri, 7. For information on the ideology of the Know Nothings see Anbinder, Nativism and Slavery, 103-126.

${ }^{54}$ Perry McCandless, A History of Missouri: Volume II, 267-270; Brock, The American Party in Missouri, 33-37, 53-58, 68-85.

55 McCandless, A History of Missouri: Volume II, 268.

${ }^{56}$ McCandless, A History of Missouri: Volume II, 269-270.

${ }^{57}$ McCandless, A History of Missouri: Volume II, 277; Brock, The American Party in Missouri, 4849, 79-80; Norma L. Peterson, "The Political Fluctuations of B. Gratz Brown: Politics in a Border State, 1850-1870," Missouri Historical Review 51, no.1 (October 1956), 24. 
materialize, but by 1856, both the Whig and American parties were declining in influence in the state and nationwide. ${ }^{58}$ The fall of the Know Nothings in Missouri can be traced to a few key factors. First, despite holding a considerable membership of roughly 20,000 in 1856, the American Party was unsuccessful in that year's municipal elections in St. Louis and various campaigns for statewide office. ${ }^{59}$ Second, with governor-elect Trusten Polk opting to fill one of the state's open US Senate seats, the American Party failed to cultivate a political alliance that would ensure the victory of a sympathetic gubernatorial candidate in 1857. Whigs, Benton Democrats, and American Party members supported James S. Rollins, but he lost a close election to Democrat Robert Stewart. ${ }^{60}$ Finally, when the Know Nothings fractured over the issues of slavery and lack of political success, prominent members defected to the Democratic, Republican, and Constitutional Union parties by the end of the 1850s. ${ }^{61}$ Ultimately, as historian Frederick Brock argues, the American Party in Missouri became more synonymous with being a "Union-saving party" than a purely nativist political organization because it could not dominate state government on just an anti-Catholic stance due to Missouri's substantial foreign-born and Catholic population. ${ }^{62}$

58 McCandless, A History of Missouri: Volume II, 277-278; Anbinder, Nativism and Slavery, 194219.

${ }^{59}$ Brock, The American Party in Missouri, 50-53, 77-78, 90-106, 146. After the 1856 general election in Missouri, the American Party claimed two Congressmen in the House of Representatives, seven state senators, and thirty-five state representatives. Brock, The American Party in Missouri, 105106.

${ }^{60}$ Brock, The American Party in Missouri, 113-127, 146.

${ }^{61}$ Brock, The American Party in Missouri, 127-129, 133-143; Anbinder, Nativism and Slavery, 246278.

62 Brock, The American Party in Missouri, 143-145. 
By the Election of 1860, the Whig and American parties were no longer active in state politics. Yet despite losing its key opposition party, the Democrats, even with the death of Thomas Hart Benton in 1858, did not move towards reconciliation with the candidacy of Claiborne Fox Jackson for governor. Due to Jackson's anti-Benton stance, some Bentonites opted for the Southern Democrat, Republican, or Constitutional Union parties. ${ }^{63}$ Most prominent was the defection of Francis P. Blair, Jr. and B. Gratz Brown to the Republicans. ${ }^{64}$ Jackson won the governor's seat and soon ushered in a state crisis over secession, but for the most part, Missouri embraced conservative unionism throughout the Civil War. ${ }^{65}$ In the presidential election of 1860 , despite budding support for the Republican, Southern Democrat, and Constitutional Union parties within the state, Missouri was the only state to give all of its electoral votes to Stephen Douglas and the Northern Democratic Party. Douglas lost, Abraham Lincoln won, and secession loomed on the horizon. ${ }^{66}$

In 1861, a state convention in Jefferson City debated the merits of secession in addition to the relationship between the state and federal government. Though most of the delegates had deep ties to the South, a majority of them were pro-Union moderates. After the convention decided to stay in the Union, pro-Confederate officials, including Governor Clayborne Fox Jackson, fled Jefferson City and set up a rogue state

${ }^{63}$ William E. Parrish, A History of Missouri: Volume III, 1860 to 1875 (Columbia: University of Missouri Press, 1973), 1-3; Astor, Rebels on the Border, 172-173.

${ }^{64}$ McCandless, A History of Missouri: Volume II, 277-279; Brock, The American Party in Missouri, 116; Peterson, "The Political Fluctuations of B. Gratz Brown," 25.

65 Parrish, A History of Missouri: Volume III, 1-2; Astor, Rebels on the Border, 173.

${ }^{66}$ Parrish, A History of Missouri: Volume III, 3; Astor, Rebels on the Border, 37, 173. 
government in Neosho. From its new headquarters in southwest Missouri, Jackson's group issued a secession order in October 1861. In response, President Jefferson Davis welcomed Missouri into the Confederacy. However, with Union forces controlling large portions of Missouri by 1862, Jackson's exile government relocated to Texas for the duration of the war. ${ }^{67}$

With Jackson's government out of Jefferson City, pro-Union politicians moved to establish a provisional government in its place and named Hamilton Gamble, a former American Party member who was seen by many as a moderate, as the new governor. While in office, Gamble attempted to appeal to Missourians through his Unionist leanings, but he could do little to stop the guerilla warfare that plagued the state. ${ }^{68}$ Despite having a pro-Union provisional government throughout the Civil War, Missouri was divided in these years as a large portion of the state's white population held close connections to the slave system. Additionally, divided loyalties between Union, proConfederacy, and neutral sentiments led to an internal rebellion that turned the state into one of the bloodiest battlefields of the western theater. ${ }^{69}$

As the Civil War neared its end, the Missouri General Assembly issued orders for the emancipation of the state's enslaved population as well as a call for a new state constitutional convention. ${ }^{70}$ An earlier attempt by John C. Fremont to emancipate slaves

${ }^{67}$ Epps, Slavery on the Periphery, 150-151; Greene, Kremer, and Holland, Missouri's Black Heritage, 77-78; Astor, Rebels on the Border, 78-81; Parrish, A History of Missouri: Volume III, 6-10, 30-41.

${ }^{68}$ Epps, Slavery on the Periphery, 150-154; Greene, Kremer, and Holland, Missouri's Black Heritage, 77-78; Astor, Rebels on the Border, 51-64, 87, 90-91, 114-120, 175-176; Parrish, A History of Missouri: Volume III, 31-32.

${ }^{69}$ Epps, Slavery on the Periphery, 150-154; Astor, Rebels on the Border, 51-64, 90-91, 114-120.

${ }^{70}$ William E. Parrish, Missouri Under Radical Rule, 1865-1870 (Columbia: University of Missouri Press, 1965), 17-18; Parrish, A History of Missouri: Volume III, 118; Greene, Kremer, and Holland, 
owned by Confederate sympathizers in Missouri was rejected and overturned by

President Abraham Lincoln in $1861 .^{71}$ Helped along by the eventual enactment of the $13^{\text {th }}$ Amendment in 1865 , the state legislature quickly approved the abolishment of slavery in Missouri. ${ }^{72}$ However, there was not an easy answer for what to do with former Confederates. While radical members of the provisional government wanted to punish Confederate sympathizers in the state through a series of strict loyalty requirements, moderates sought to promote reunion more than revenge. ${ }^{73}$

Led by Charles Drake, the 1865 state constitutional convention aimed to address the loyalty of former Confederates while promoting African American rights. ${ }^{74}$ Over the objections of a portion of the delegates, Drake supporters pushed through an iron clad oath that required individuals within the state to swear loyalty to the new government and prove their innocence regarding possible support for the Confederacy. This iron clad oath became the prerequisite for voting and office holding in the state during the early years of Reconstruction. While aimed primarily at politicians, the oath also applied to jurors, lawyers, teachers, and members of the clergy. Knowing that such a requirement

Missouri's Black Heritage, 88; Fred DeArmond, "Reconstruction in Missouri," Missouri Historical Review 61, no. 3 (April 1967), 369.

${ }^{71}$ Greene, Kremer, and Holland, Missouri's Black Heritage, 76; Astor, Rebels on the Border, 107; Parrish, A History of Missouri: Volume III, 36, 87-88; Efford, German Immigrants, Race, and Citizenship in the Civil War Era, 94.

72 Parrish, Missouri Under Radical Rule, 17-18; Parrish, A History of Missouri: Volume III, 118; Greene, Kremer, and Holland, Missouri's Black Heritage, 88; DeArmond, "Reconstruction in Missouri," 369.

73 Parrish, A History of Missouri: Volume III, 121; Epps, Slavery on the Periphery, 188-190; Astor, Rebels on the Border, 171-172, 178-180; DeArmond, "Reconstruction in Missouri," 373.

${ }^{74}$ Parrish, Missouri Under Radical Rule, 115-116; Parrish, A History of Missouri: Volume III, 123124; Epps, Slavery on the Periphery, 188-190; Greene, Kremer, and Holland, Missouri's Black Heritage, 9495; Astor, Rebels on the Border, 150-153; DeArmond, "Reconstruction in Missouri," 373. 
would disfranchise a significant portion of the Democratic Party's base, Radical-leaning delegates saw a chance to promote progressive legislation in the state between the time of the oath's passage until at least 1871, the first year that the General Assembly could review bills concerning revoking or revising the oath. ${ }^{75}$ When voters went to the polls in June 1865, the Drake Constitution had gained the support of convention delegates as well as several of the state's Congressmen. However, the document faced an uphill battle thanks to heavy opposition in St. Louis and southeastern Missouri. Nevertheless, despite claims of inconsistencies in voting totals by the Radicals, the constitution narrowly passed due to overwhelming support from Union soldiers. ${ }^{76}$

More than any other piece of legislation pursued by the Radicals, the 1865 Constitution's ironclad oath was hated the most by opponents of Charles Drake. On multiple occasions, the oath's legality faced scrutiny. In addition to Frank Blair, Jr., who emerged as a formidable anti-Radical leader at the close of the Civil War, prominent Catholics, including Archbishop Peter R. Kenrick, challenged the oath. Kenrick objected to the ironclad oath's loyalty restrictions upon ministers and confessed that he could not morally submit to such a requirement. Father John A. Cummings of Louisiana, Missouri, shared Kenrick's opposition. Cummings, who failed to abide by the requirements of the oath, continued to preach to his congregation until he was indicted by a grand jury for his actions. Though he welcomed the trial as a means to challenge the oath, Cummings was

\footnotetext{
75 Parrish, Missouri Under Radical Rule, 27-29; Parrish, A History of Missouri: Volume III, 121; Epps, Slavery on the Periphery, 188-190; Astor, Rebels on the Border, 171-172, 178-180; Efford, German Immigrants, Race, and Citizenship in the Civil War Era, 96.

${ }^{76}$ Parrish, A History of Missouri: Volume III, 127-128; Efford, German Immigrants, Race, and Citizenship in the Civil War Era, 111-113.
} 
found guilty and fined $\$ 500$. When he refused to pay, he was confined in the Pike County jail. ${ }^{77}$

To those that were affected by the ironclad oath, Father Cummings became a quasi-martyr for the cause. After the Radical-aligned judges of the state Supreme Court ruled against him in October 1865, Cummings' case was appealed to the United States Supreme Court. By 1866, when his case was heard before that body, Cummings' treatment had become a rallying cry for anti-Radicals. Frank P. Blair, Jr. called upon President Andrew Johnson to strike down the oath. Blair's alliance with Johnson is interesting considering the tension between the president and congressional Republicans. However, Blair's angle was to support Johnson in his efforts to scale back Reconstruction and return states to local control. ${ }^{78}$ Ultimately, the US Supreme Court ruled in favor of Cummings when his appeal reached that body, but despite striking down key elements of the loyalty requirements, the ironclad oath was not revoked until the early 1870 s. $^{79}$

Beyond the ironclad oath, one of the key topics debated by the Radical-controlled state legislature during Reconstruction was suffrage for African Americans. However, the idea of universal suffrage was not new in the state. Senator B. Gratz Brown had been a supporter of the idea as early as the mid-1860s. Additionally, the push for suffrage had the backing of Governor Thomas C. Fletcher. ${ }^{80}$ But not all Radicals were on board with

\footnotetext{
77 Parrish, Missouri Under Radical Rule, 58-66; Parrish, A History of Missouri: Volume III, 128-134.

78 Parrish, Missouri Under Radical Rule, 68-69; Parrish, A History of Missouri: Volume III, 135-136.

${ }^{79}$ Parrish, Missouri Under Radical Rule, 69-75; Parrish, A History of Missouri: Volume III, 134-136; Astor, Rebels on the Border, 183.

${ }^{80}$ Parrish, A History of Missouri: Volume III, 144, 147; Efford, German Immigrants, Race, and Citizenship in the Civil War Era, 175; Peterson, "The Political Fluctuations of B. Gratz Brown," 25-27.
} 
expanded rights for former slaves. ${ }^{81}$ Most prominently, Charles Drake objected to black enfranchisement because he feared that it would never pass through a popular vote. If the 1865 constitution included such a proposal, Drake worried that the entire document would go down in defeat. In an effort to compromise, Drake supported expanded civil rights for Missouri's African American population as long as suffrage and office holding were not included. ${ }^{82}$

Drake's opposition to black suffrage roiled two prominent groups in the state Republican Party, German Radicals and African Americans. As Drake's power in the state increased, especially after his appointment to the United States Senate in 1866, Germans in the eastern portion of the state began to turn more towards B. Gratz Brown's liberal brand of republicanism. ${ }^{83}$ To boost the civil rights proposed by the Radicals, an interracial alliance of Republicans created the Missouri Equal Rights League in 1865. While the Equal Rights League was successful in mobilizing Missourians to the cause of civil rights for African Americans, including having speakers tour the state on the group's behalf, the organization was unable to sway the General Assembly to fully embrace black suffrage. ${ }^{84}$ It would take until the ratification of the $15^{\text {th }}$ Amendment to the United States

${ }^{81}$ Parrish, Missouri Under Radical Rule, 115-118; Parrish, A History of Missouri: Volume III, 144.

82 Parrish, Missouri Under Radical Rule, 115-118; Parrish, A History of Missouri: Volume III, 146147; Epps, Slavery on the Periphery, 188-190; Efford, German Immigrants, Race, and Citizenship in the Civil War Era, 97.

83 Parrish, Missouri Under Radical Rule, 100-104; Parrish, A History of Missouri: Volume III, 233235; Efford, German Immigrants, Race, and Citizenship in the Civil War Era, 93.

${ }^{84}$ Parrish, Missouri Under Radical Rule, 133-137; Parrish, A History of Missouri: Volume III, 147149; Epps, Slavery on the Periphery, 188-190; Greene, Kremer, and Holland, Missouri's Black Heritage, $95-$ 97; Astor, Rebels on the Border, 150-153. 
Constitution before the Missouri General Assembly authorized full suffrage rights for African American men. ${ }^{85}$

In addition to the eventual embrace of black male suffrage, the Radical-controlled General Assembly also issued a series of laws concerning education rights during Reconstruction. These new measures required local boards of education to establish and maintain separate school facilities for whites and blacks if the number of black students exceeded twenty. If the total was less than twenty, the state allowed the school boards to decide on integrated or separate accommodations as they saw fit. Despite the attempt to establish educational opportunities, even in cases of segregation, the state legislature offered little enforcement over school boards that skirted the law. Apathy, combined with funding issues, ensured that education remained separate and unequal in Reconstruction Missouri. ${ }^{86}$ Nevertheless, the Reconstruction Period in Missouri witnessed a substantial growth in black education, including the establishment of Lincoln Institute (later Lincoln University) in $1866 .^{87}$

Though they dominated state politics from the close of the Civil War through the early 1870s, the Radicals could not hold on to control forever. They were well aware of the potential fallout that would result from the re-enfranchisement of those restricted under the ironclad oath. Additionally, in-fighting - especially between Drake supporters

85 Parrish, Missouri Under Radical Rule, 272-273; Parrish, A History of Missouri: Volume III, 250251; Lawrence O. Christensen, "Race Relations in St. Louis, 1865-1916," Missouri Historical Review 78, no. 2 (January 1984): 130-131; Greene, Kremer, and Holland, Missouri's Black Heritage, 96-97; Astor, Rebels on the Border, 178.

${ }^{86}$ Parrish, Missouri Under Radical Rule, 118-132; Parrish, A History of Missouri: Volume III, 161162.

\footnotetext{
${ }^{87}$ Parrish, Missouri Under Radical Rule, 128-132; Parrish, A History of Missouri: Volume II, 166-
} 169. 
and German radicals - threatened to splinter the postwar coalition. With the ouster of US Senator John P. Henderson, an ardent supporter of President Andrew Johnson, by the Radicals in 1867, Drake hoped to fill the open seat with one of his lieutenants. Instead, Radicals, including a growing faction of St. Louis German Republicans, successfully pushed for Carl Schurz. ${ }^{88}$ A native of Germany, Schurz came to the United States after the 1848 revolutions. Following an appointment as Abraham Lincoln's Minister to Spain and a successful stint in the Union Army as a brigadier general during the Civil War, Schurz moved to St. Louis. He quickly gained the support of the state's German population and parlayed his editorial work with the Westiche Post into a political career in the US Senate. ${ }^{89}$ While occupying the office, however, Schurz began to turn against the Republican Party, particularly President Ulysses S. Grant and fellow senator Charles Drake..$^{90}$

The growing distrust from German Missourians towards Drake and the Radicals led to the substantial decline of Republican rule in the state. Led by Carl Schurz and B. Gratz Brown, the Liberal Republican movement initially started as an attempt to establish a rival third party. Supporters voiced concerns that the Radicals cared more about the spoils of victory than attempting to unify the various factions of the state. In an effort to promote harmony and cooperation, the Liberal Republicans reached out to disfranchised former Confederates as well as African Americans. Both groups were promised

88 Parrish, Missouri Under Radical Rule, 229-234, 250-251, 258-267; Parrish, A History of Missouri: Volume III, 236-237, 248-249; Efford, German Immigrants, Race, and Citizenship in the Civil War Era, 137142.

${ }^{89}$ Parrish, Missouri Under Radical Rule, 229-234; Parrish, A History of Missouri: Volume III, 236237; Efford, German Immigrants, Race, and Citizenship in the Civil War Era, 137-142.

90 Parrish, A History of Missouri: Volume III, 257-259. 
expanded rights under the Liberal Republican banner. Despite attempts to connect with these two groups, African Americans largely remained within the traditional Republican Party. However, a growing coalition of Democrats and former Confederates attached themselves to the Liberal Republicans. In the 1870 election, coordinated efforts between Democrats and the liberals resulted in a substantial victory for Liberal Republicans in the state. $^{91}$

With Liberal Republican leader B. Gratz Brown taking his place as governor in Jefferson City, the 1870s opened with great promise for the Democrat/Liberal coalition. These prospects increased when Charles Drake opted to resign his Senate seat in favor of accepting an appointment as the Chief Justice of the United States Court of Claims. ${ }^{92}$ Moving quickly in the aftermath of the election, the coalition nominated Francis P. Blair, Jr. to fill the open senate seat and join Carl Schurz in Washington D.C. Blair's Civil War service and prior nomination to be Horatio Seymor's running mate in the 1868 presidential election greatly aided his candidacy. His familial ties to Governor Brown also helped the burgeoning anti-Radical politician. ${ }^{93}$

Though B. Gratz Brown and Francis P. Blair Jr. occupied their present positions with eyes on the White House, both men had to address the growing violence and terrorism that plagued large sections of the American South, including Missouri. Born in

\footnotetext{
${ }^{91}$ Parrish, Missouri Under Radical Rule, 286-312; Parrish, A History of Missouri: Volume III, 260265; Efford, German Immigrants, Race, and Citizenship in the Civil War Era, 171-181; Peterson, "The Political Fluctuations of B. Gratz Brown," 28-29; DeArmond, "Reconstruction in Missouri," 373-374.

92 Parrish, Missouri Under Radical Rule, 314; Parrish, A History of Missouri: Volume III, 268-270; DeArmond, "Reconstruction in Missouri," 375.

93 Parrish, Missouri Under Radical Rule, 249-250, 315-317; Parrish, A History of Missouri: Volume III, 238-243, 270-271; Eric Foner, Reconstruction: America's Unfinished Revolution, 1863-1877 (New York: Harper \& Row, 1988), 339-341, 421.
} 
Pulaski, Tennessee in 1866, the Ku Klux Klan became the symbol for this wave of violence. Its creators, however, were not the backwoods ruffians of assumed lore, but rather educated former Confederate soldiers. ${ }^{94}$ As historian Elaine Frantz Parsons has argued, they were "elites and intellectuals, above and opposed to the violence of rough men, but also...men who felt the stern responsibility to restore their collapsed society." ${ }^{95}$ The origin story of the Klan suggests social fraternity, not vigilantism, as the intention of group founders. Yet, the Klan and its intentions would not remain solely in Pulaski. By early 1868 , particularly in the run up to that year's election, the Klan had spread beyond Tennessee. Less than five years after the Civil War, the Klan existed in most of the states of the old Confederacy. ${ }^{96}$

While the Klan found support among former Confederates, its most fertile recruitment bases were actually in communities with a relatively even ratio of white and black residents, and where two party politics was common. ${ }^{97}$ Yet, despite some success in more diverse counties, historian Eric Foner has found that "the Klan was a military force serving the interests of the Democratic Party, the planter class, and all those who desired the restoration of white supremacy." 98 The "redemption" that the Ku-Klux soon embraced led to an uptick in violence throughout portions of the South. However, as Elaine Frantz Parsons has noted, the spread of the Klan was sporadic, incomplete, and

\footnotetext{
${ }^{94}$ Elaine Frantz Parsons, Ku-Klux: The Birth of the Klan during Reconstruction (Chapel Hill: University of North Carolina Press, 2016), 7, 27-71. Wade, The Fiery Cross, 31-79.

${ }^{95}$ Parsons, Ku-Klux, 30.

${ }_{96}$ Parsons, Ku-Klux, 7-8, 27-71; Foner, Reconstruction, 425-429; Wade, The Fiery Cross, 31-79.

${ }^{97}$ Foner, Reconstruction, 430-431; Parsons, Ku-Klux, 7-8.

${ }^{98}$ Foner, Reconstruction, 425.
} 
uneven. The Reconstruction Klan was never centrally organized like its early twentieth century successor. In fact, despite former Confederate Nathan Bedford Forrest claiming the title of Imperial Wizard, supposed leaders of the Ku-Klux had little control over members outside of their community. ${ }^{99}$

Though the Ku-Klux of the Reconstruction period was far from organized, individuals that donned various costumes associated with the Klan shared several key elements. First, the Klan's violence targeted African Americans and white Republicans in an attempt to subvert new rights provided by the federal government and regain control over the labor system of the South. ${ }^{100}$ Second, Klan members came from all sections of southern life. While it is sometimes assumed that Klansmen were backwoods vigilantes, scholars like Eric Foner and Elaine Frantz Parsons have found that a local Klan contained a representative cross-section of community members. ${ }^{101}$ Finally, from its beginnings, the Klan aimed to reestablish local control in many southern communities and push out Republicans from power. ${ }^{102}$

While the Klan's attacks upon individuals may have been sporadic throughout the South, citizens that suffered from midnight terrorism called upon local, state, and federal officials to suppress the violence. For the most part, state governors monitored the situation surrounding alleged Klan atrocities, but did little to stop it. Due to their tenuous hold over state politics, many politicians, particularly Republicans, feared a backlash if

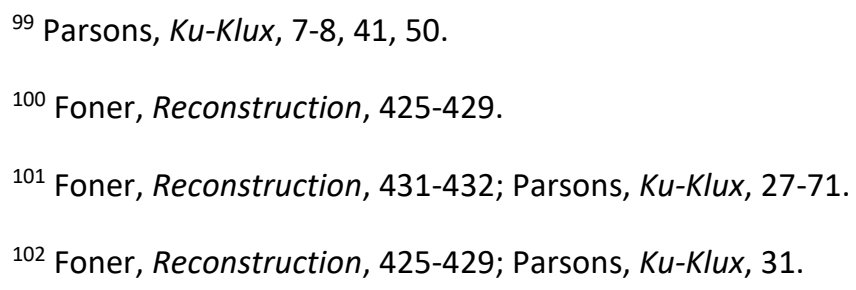


they attempted to confront the Klan. ${ }^{103}$ However, by 1871, hundreds of individuals in states like North Carolina, Mississippi, and South Carolina, faced indictment for their role in the violence. ${ }^{104}$ The Carolinas proved to be the center of not only Klan atrocities, but also of suppression of violence. In October 1871, President Grant proclaimed martial law in portions of South Carolina. After suspending the writ of habeas corpus, he sent federal troops to the state. The newly arriving soldiers arrested hundreds of individuals, and slowly pushed the Klan out of the state. ${ }^{105}$

As the Carolina example indicates, the federal government, not the states, played a larger role in suppressing Klan violence. This activism came about through the Enforcement Acts. Passed by Congress in 1870 and 1871, the Enforcement Acts dealt primarily with discrimination and violence. The first Act held close ties to the $15^{\text {th }}$ Amendment and forbade state officials from discriminating against potential voters based upon race. The Act gave the president the authority to appoint election supervisors to monitor instances of fraud, bribery, and voter intimidation. The supervisors could also bring cases involving voter suppression before a federal court. A second component of the Act dealt with voting integrity in northern and southern cities. ${ }^{106}$

While the 1870 Enforcement Act was primarily concerned with voting rights, it did little to address violence. As such, Congress felt the need to amend the law with another Enforcement Act in 1871. Called the Ku Klux Klan Act, the 1871 law

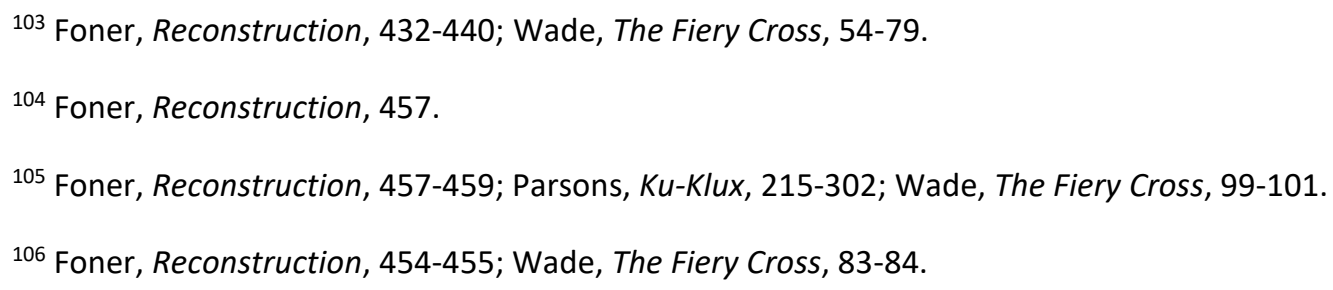


designated certain criminal offenses as punishable under the federal government, including conspiracy to prevent a citizen from voting, holding public office, or serving on juries. Essentially, the Act held that if states did not uphold key elements of the $14^{\text {th }}$ Amendment, they would be subject to federal prosecution and even military intervention. The Ku Klux Klan Act brought forth more rigorous suppression of violence at the state level, with governors like Missouri's B. Gratz Brown warning residents that if local officials did not deal with atrocities then state and federal intervention would follow. ${ }^{107}$

Prior to 1868 , the Klan was an unknown entity within Missouri. While political terrorism connected to vigilantism and bushwacking had existed throughout the Civil War and early Reconstruction period, it did not fall under the banner of the Klan. The flames of the Klan movement were fanned, however, by the state's conservative and Democrat press, particularly in sections of Little Dixie, that opposed the civil rights pushed by the Radicals and favored a return to the "white man's country" that presidential candidate Horatio Seymour promoted. In the election years of 1868 and 1870, the conservative press, particularly the Lexington Weekly Caucasian, played up fears of black rights while also promoting the mysterious rituals of the Ku-Klux or K.K.K. ${ }^{108}$ Far from influencing the 1868 Election, the Klan hid in the Missouri shadows for most of the 1860s. It was not until the early 1870s that alleged Klan atrocities became more visible in southeastern Missouri and portions of Little Dixie. Even then, however,

${ }^{107}$ Foner, Reconstruction, 454-455; Parsons, Ku-Klux, 184-186; Wade, The Fiery Cross, 83-90.

${ }^{108}$ Astor, Rebels on the Border, 140-141, 168-169, 178, 181, 191; John Starrett Hughes, "Lafayette County and the Aftermath of Slavery, 1861-1870," Missouri Historical Review 75, no. 1 (October 1980), 54-58; Aaron Astor, "The Lexington Weekly Caucasian: White Supremacist Discourse in Post-Civil War Western Missouri," in Bleeding Kansas, Bleeding Missouri: The Long Civil War on the Border, ed. Jonathan Earle and Diane Mutti Burke (Lawrence: University of Kansas Press, 2013), 189-203. 
the attacks were sporadic at best and largely failed to impact political activity. ${ }^{109}$

Nevertheless, some of Missouri's political leaders felt that something had to be done to prevent the state from replicating the violence that terrorized the South.

Following the passage of the federal Ku Klux Klan Act in 1871, Missouri governor B. Gratz Brown utilized it as a mechanism to deal with cases of vigilantism around the state. Though the conservative press denounced the Act, Brown, citing the new law, used the state militia, local law enforcement, and deputized private citizens to rein in suspected Klan activity. ${ }^{110}$ However, as historian Aaron Astor has noted, government officials and some members of the Radical press were quick to label any violence as Klan activity even when the evidence was largely non-existent. ${ }^{111}$ Nevertheless, Brown responded in full to citizens' requests for government intervention against the Klan because, as one letter writer informed the governor, these attacks "make us mutch [sic] trouble and give this part of Missouri A bad name.”112

When violence flared up in southeast Missouri, Brown and Adjunct General Albert Sigel dispatched Edmund S. Woog to investigate the matter. Traveling through three counties, Woog noted in a letter to Sigel that much of the activity was tied to the

${ }^{109}$ Parrish, A History of Missouri: Volume III, 282; Astor, Rebels on the Border, 190-192, 230; Hughes, "Lafayette County and the Aftermath of Slavery," 58; DeArmond, "Reconstruction in Missouri," 377; David Thelen, Paths of Resistance: Tradition and Democracy in Industrializing Missouri (Columbia: University of Missouri Press, 1991), 60-61.

${ }^{110}$ For Brown's response to alleged Klan activity see Parrish, A History of Missouri: Volume III, 282; E.M. Lick to B. Gratz Brown, 20 June 1871, Benjamin Gratz Brown Collection, Missouri State Archives, Jefferson City, Missouri (hereafter cited as BGB and MSA-JC); A.J. Barker to B. Gratz Brown, 29 June 1871, BGB, MSA-JC; Edmund S. Woog to Albert Sigel, 4 October 1871, BGB, MSA-JC; James Shelton Alsup to B. Gratz Brown, 21 January 1872, BGB, MSA-JC; W. Lawson to B. Gratz Brown, 14 March 1872, BGB, MSA-JC; E.K. Cooper to B. Gratz Brown, 3 April 1872, BGB, MSA-JC.

${ }^{111}$ Astor, Rebels on the Border, 191.

112 E.M. Lick to B. Gratz Brown, 20 June 1871, BGB, MSA-JC. 
Ku-Klux, or the "Dead Men" as residents of Stoddard County called the group, but the organization was "nothing less than a band of robbers, murderers \& horse thieves." Though quick to attack the Klan for its alleged role in the atrocities, Woog also criticized local residents for their complicity in the events because "instead of manfully shouldering a gun to hunt down this band... and bring them to justice, [they] sign a petition, humbly asking these cut throats to please stop, and not rob, whip and murder any more...this document, in my opinion, instead of suppressing the disorders, will only make the band bolder and more determined." 114 While Woog and Brown supported the idea of deputizing private citizens to stop Klan attacks and arrest those responsible, some Missouri residents complained that these county militias were infiltrated by the Ku-Klux and used as an intimidating force under the cover of a badge. ${ }^{115}$ Additionally, the conservative press was quick to attack the governor and state officials when atrocities allegedly committed by the Klan turned out to be more myth than reality upon closer review, as was the case in Saline County in $1872 .{ }^{116}$

At its base, however, the fight against the Reconstruction Klan was somewhat successful at the state and national level. Despite several key setbacks, including limited enforcement budgets, complications in obtaining criminal evidence, strong defense from accused individuals, and problems surrounding witness intimidation, the Ku Klux Klan Act brought forth hundreds of indictments against alleged vigilantes. Additionally,

\footnotetext{
${ }^{113}$ Edmund S. Woog to Albert Sigel, 4 October 1871, BGB, MSA-JC.

${ }^{114}$ Edmund S. Woog to Albert Sigel, 4 October 1871, BGB, MSA-JC.

${ }^{115}$ E.K. Cooper to B. Gratz Brown, 3 April 1872, BGB, MSA-JC.

${ }^{116}$ Lexington Intelligencer, 10 January 1872, 17 January 1872.
} 
multiple states created citizen militias to aid law enforcement in rounding up suspected Ku-Klux members. Finally, the Act helped restore order to portions of the South and allowed African Americans to exert greater citizenship rights. While the protection of these rights may have been short lived with the rise of redeemer governments in the South, the Ku Klux Klan Act served as an effective tool in combatting the nation's terrorist epidemic immediately following the Civil War. ${ }^{117}$

Though it proved successful in curtailing some of the violence, the Ku Klux Klan Act met with stiff opposition from Democrats for a variety of reasons. Members of the party, particularly those in southern states, declared that this "Force Act" was a direct threat to local control and individual freedom. Democratic opposition also accompanied concerns voiced by some Republicans against the Act. Carl Schurz of Missouri proved to be one of the staunchest opponents of the Enforcement Acts because he considered the Ku Klux Klan Act to be an excessive example of federal control. ${ }^{118}$ Combined with concerns over Reconstruction policies, opposition to the Ku Klux Klan Act brought forth a growing alliance between Democrats and Liberal Republicans.

Blair and Brown might have assumed that their reaction to the $\mathrm{Ku}$ Klux Klan and opposition to Reconstruction would propel them to be serious contenders in the 1872 presidential campaign, but the Democratic Party had other plans. Though the Democrats aligned with the Liberal Republicans to back Horace Greeley for president, the move left Blair and Brown on the outside looking in. When it became obvious that neither would

\footnotetext{
${ }^{117}$ Foner, Reconstruction, 457-459.

${ }^{118}$ Foner, Reconstruction, 455-457; Parsons, Ku-Klux, 159, 162, 167; Efford, German Immigrants, Race, and Citizenship in the Civil War Era, 183-185.
} 
secure the nomination, both Blair and Brown moved to support Greeley. It was an uncomfortable alliance given Greeley's previous denunciations of Democratic policies, but the move paid off for Brown in his selection to be Greeley's running mate. However, though Brown carried Missouri for the Liberal Republicans, U.S. Grant defeated Greeley handily in November. The defeat resonated throughout the Liberal Republican movement and it soon folded in the mid-1870s. ${ }^{119}$ Due to their previous ties with the party at the state level, many of Missouri's Liberal Republicans soon merged with the Democrats. By 1875, only ten years after the establishment of Radical rule in the state, the Democratic Party, thanks to the splintering of the Republicans and the reenfranchisement of former Confederates, dominated politics in Missouri. ${ }^{120}$

Radical Reconstruction came to an end in Missouri in 1875. In that year, a newly convened constitutional convention met in Jefferson City to revise the state's constitution and roll back the policies put into place by the earlier Drake constitution. According to historians Lawrence O. Christensen and Gary R. Kremer, the 1875 Convention "set the tone for political life in Missouri for the remainder of the century." ${ }^{121}$ Over the span of two and a half months, the convention, dominated by conservative Democrats, reversed many of the policies of the 1865 constitution and pushed for localism over state power. While proponents argued that the new constitution, approved by voters in August 1875,

${ }^{119}$ Foner, Reconstruction, 502; Efford, German Immigrants, Race, and Citizenship in the Civil War Era, 185, 194-198; Peterson, “The Political Fluctuations of B. Gratz Brown," 29-30.

${ }^{120}$ Lawrence O. Christensen and Gray Kremer, A History of Missouri: Volume IV, 1875 to 1919 (Columbia: University of Missouri Press, 1997), 1-27.

${ }^{121}$ Christensen and Kremer, A History of Missouri: Volume IV, 1. 
expanded the individual liberty of state residents, Radicals saw the document as a rejection of Republican policies towards regulating state affairs. ${ }^{122}$

In addition to their conservative leanings, a majority of the delegation also held southern sentiments. While roughly $75 \%$ had been born in southern states, over half of the attendees held sympathies with the former Confederate States of America. Nowhere was this more evident than in the appointment of Waldo P. Johnson of St. Clair County as chairman. A native of Virginia, Johnson had been active in Missouri politics since the 1840s. In 1862, while representing the state in the United States Senate, he was expelled from Congress for disloyalty. He later served in the Confederate Army under General Sterling Price, and earned an appointment to represent Missouri in the Confederate Congress. Like many of his fellow ex-Confederates, Johnson spent the years immediately following the Civil War outside of the United States, but eventually returned to the state as if nothing had ever happened. After a short period of disenfranchisement, Johnson, and others, came back into power and revised the state constitution to fit their desire for small government and local control. ${ }^{123}$

The 1875 Constitution ushered in an era of dominance for the Democratic Party within the state. Beginning with the victory of Silas Woodson in 1872, no Republican held the office of governor until 1909. Yet, while Democrats occupied the governor's chair throughout this period, a majority of these men either supported the Union or had

122 Christensen and Kremer, A History of Missouri: Volume IV, 1-5; Greene, Kremer, and Holland, Missouri's Black Heritage, 100-101.

${ }^{123}$ Christensen and Kremer, A History of Missouri: Volume IV, 2; Lloyd A. Hunter, "Missouri's Confederate Leaders After the War," Missouri Historical Review 67, no. 3 (April 1973): 371-396. 
taken no part in the war. ${ }^{124}$ However, as indicated by their strength in the constitutional convention, former Confederates wielded tremendous power in state politics. ${ }^{125}$ When George C. Vest won election to the US Senate in 1879, former Confederates filled both of the state's seats in that body until his death in 1903. Fellow senator Francis Cockrell who had been a brigadier general in the Confederate Army joined Vest, who served in the Confederate Congress during the Civil War. Cockrell served in Congress until the early $20^{\text {th }}$ Century when a Republican revival within the state pushed him out of office. ${ }^{126}$

Though the "redemption" of the state by the Democratic Party was swift in the 1870s, Missouri's "redeemers" did not fully replicate politics from other southern states. While the rollback of civil rights at the state and federal level was widespread in the latter half of the $19^{\text {th }}$ century, Missouri came to represent a state where African Americans could find better opportunities than in other southern states. Additionally, the state never fully embraced a system of de jure segregation. While some rural politicians repeatedly tried to enact laws aimed at segregating public accommodations and disfranchising black voters, urban Democrats and Republicans repeatedly rejected these bills. Nevertheless, elements of Jim Crow slowly made their way into the state by 1900 with local laws aimed at racial separation as well as a growing support for de facto segregation. ${ }^{127}$ Perhaps the

${ }^{124}$ Christensen and Kremer, A History of Missouri: Volume IV, 6-25; Greene, Kremer, and Holland, Missouri's Black Heritage, 105.

${ }^{125}$ Hunter, “Missouri's Confederate Leaders After the War," 371-396.

${ }^{126}$ Hunter, “Missouri's Confederate Leaders After the War," 389-395.

127 Schirmer, A City Divided, 28-32, 42-57, 64-71; Christensen, “Race Relations in St. Louis, 18651916," 123-136; Thelen, Paths of Resistance, 139. 
most wide sweeping change was a state law enacted after the 1875 constitutional convention that furthered the racial segregation of Missouri's public schools. ${ }^{128}$

With the Republican Party largely out of power in the state during the latter half of the $19^{\text {th }}$ century, Missouri's African American population began to look for political alternatives to advance civil rights. As a voting bloc, they were not prepared to fully embrace the Democrats, especially considering the dominance by former Confederates within the party's rural faction. Yet, with Republicans seemingly backing lily-white policies, particularly in portions of southern Missouri, African Americans in urban communities began to gauge interest in a move towards the Democrats. ${ }^{129}$ By the turn of the $20^{\text {th }}$ Century, Democrat-aligned political machines began to lay the groundwork for an alliance with blacks in Kansas City and St. Louis. This growing coalition led to James A. Reed's mayoral victory in Kansas City in 1900, but the alliance was tenuous at best. Despite earning valuable patronage positions from the Reed administration, African Americans had to continually convince the state Democratic Party to ignore the racist and segregationist policies pursued by rural Democrats. ${ }^{130}$ In the end, a majority of Missouri's African American voters were not yet ready to leave the Republican Party, especially after state-level victories for the Republicans in the first quarter of the $20^{\text {th }}$

\footnotetext{
${ }^{128}$ Christensen and Kremer, A History of Missouri: Volume IV, 59; Christensen, "Race Relations in St. Louis, 1865-1916," 125-127; Thelen, Paths of Resistance, 139; Greene, Kremer, and Holland, Missouri's Black Heritage, 107; Efford, German Immigrants, Race, and Citizenship in the Civil War Era, 221-222.

${ }^{129}$ Greene, Kremer, and Holland, Missouri's Black Heritage, 111-112; Christensen and Kremer, $A$ History of Missouri: Volume IV, 147-148; Schirmer, A City Divided, 64-71; Christensen, "Race Relations in St. Louis, 1865-1916," 132; Larry Grothaus, "Kansas City Blacks, Harry Truman, and the Pendergast Machine," 67.

${ }^{130}$ Greene, Kremer, and Holland, Missouri's Black Heritage, 111-112; Christensen and Kremer, $A$ History of Missouri: Volume IV, 147-148, 179; Schirmer, A City Divided, 64-71; Christensen, "Race Relations in St. Louis, 1865-1916," 132; Thelen, Paths of Resistance, 140; Grothaus, "Kansas City Blacks, Harry Truman, and the Pendergast Machine," 67.
} 
Century. ${ }^{131}$ Ultimately, as will be seen in Chapter 7, this shift would not take place until the early 1930s.

Beyond political realignment, and a growing push among rural and municipal legislators to harden the separation between the races, the greatest concern for African Americans in Missouri at the turn of the $20^{\text {th }}$ Century was lynching and racial violence within the state. As with earlier examples of vigilantism that plagued the state during the $1860 \mathrm{~s}$ and $1870 \mathrm{~s}$, the lynch mob mentality of the late $19^{\text {th }}$ and early $20^{\text {th }}$ centuries was rampant in rural Missouri despite objections from some of the state's most prominent politicians. Though actively pursuing criminal investigations against suspected mob members, Missouri's early $20^{\text {th }}$ Century governors received little help from Congress, the General Assembly, or local authorities. ${ }^{132}$ Between 1889 and 1918, eighty-one lynchings occurred within the state. Of those eighty-one, fifty-one victims were African Americans. ${ }^{133}$ While certainly not rivaling the number of lynching atrocities of states like Mississippi, Texas, and Georgia, Missouri did have one of the highest lynching totals of Upper South states. ${ }^{134}$ Additionally, between 1898 and 1915, five counties, Pike, Mississippi, Greene, Lawrence, Howard, experienced at least three lynchings each. ${ }^{135}$

${ }^{131}$ Greene, Kremer, and Holland, Missouri's Black Heritage, 112; Christensen and Kremer, $A$ History of Missouri: Volume IV, 148, 186; Schirmer, A City Divided, 64-71; Christensen, "Race Relations in St. Louis, 1865-1916," 132; Grothaus, "Kansas City Blacks, Harry Truman, and the Pendergast Machine," 67.

132 Greene, Kremer, and Holland, Missouri's Black Heritage, 108-112; Harriet C. Frazier, Lynchings in Missouri, 1803-1981 (Jefferson: McFarland, 2009), 79-162.

${ }^{133}$ Greene, Kremer, and Holland, Missouri's Black Heritage, 108-109; Frazier, Lynchings in Missouri, 198-201.

${ }^{134}$ Greene, Kremer, and Holland, Missouri's Black Heritage, 108-109.

${ }^{135}$ Frazier, Lynchings in Missouri, 105-162, 199-201. 
The most grotesque were a set of triple lynchings that occurred in Pierce City in 1901 and Springfield in $1906 .{ }^{136}$ The threat of a murderous mob was also usually accompanied by the expulsion of a community's black population in the wake of the lynching. Whether caused by a personal flight for safety or the racial "cleansing" of a town, most African Americans opted to leave rural Missouri behind in favor of nearby cities. ${ }^{137}$

In response to the rise of lynching, African Americans in Missouri turned to state and federal officials, as well as new organizations like the National Association for the Advancement of Colored People, to protect them from the violence. Beginning with Joseph Folk's victory in 1904 , the first quarter of the $20^{\text {th }}$ Century saw increased activity on the part of Missouri's governors to stem the tide of lynching. Frequently, governors would send the National Guard to the afflicted county in the hopes of preventing further violence. ${ }^{138}$ However, as groups like the NAACP noted, mob members would commit the crime and rarely be held liable in the court system. Following its establishment in 1909, the NAACP set out to fight discrimination and segregation across the nation, yet an anti-lynching crusade would become perhaps its most significant contribution in the early years of its history. ${ }^{139}$ By the early 1920s, the NAACP had grown to prominence

\footnotetext{
136 Greene, Kremer, and Holland, Missouri's Black Heritage, 109-110; Frazier, Lynchings in Missouri, 137-139, 141-144; Kimberly Harper, White Man's Heaven: The Lynching and Expulsion of Blacks in the Southern Ozarks, $1894-1909$ (Fayetteville: University of Arkansas Press, 2010), 1-67, 109-234.

${ }^{137}$ Greene, Kremer, and Holland, Missouri's Black Heritage, 107-114; Thelen, Paths of Resistance, 92-99; Frazier, Lynchings in Missouri, 135-162. For a detailed study of racial violence and the expulsion of African Americans from portions of southern Missouri see Kimberly Harper, White Man's Heaven: The Lynching and Expulsion of Blacks in the Southern Ozarks, 1894-1909 (Fayetteville: University of Arkansas Press, 2010).

138 Greene, Kremer, and Holland, Missouri's Black Heritage, 108-112.

${ }^{139}$ Megan Ming Francis, Civil Rights and the Making of the Modern American State (New York: Cambridge University Press, 2014), 29-58; Patricia Sullivan, Life Every Voice and Sing: The NAACP and the Making of the Civil Rights Movement (New York: The New Press, 2009), 1-24.
} 
throughout the United States and established branches in St. Louis, Kansas City, Springfield, Cape Girardeau, and Caruthersville within the state. ${ }^{140}$

With the rise of lynching in the latter half of the $19^{\text {th }}$ Century, African American turned increasingly to the Republican Party to protect their civil rights. The party, however, was in a period of fluctuation. While members continued to back elements of civil rights legislation, a growing support for big business and lily-white politics soon took over the Republican Party. As discussed before, such a move led to wavering support by African Americans at the end of the century. ${ }^{141}$ But the Republican Party expressed few fears about the threat of political abandonment by African Americans. Instead, the party tried to grow its base by appealing to an element of the electorate concerned about increasing immigration to the United States. Though not new in American politics or society, the late $19^{\text {th }}$ Century embrace of nativism produced a groundswell of support for immigration restrictions and religious intolerance. The result was a Republican Party that appealed to members of a new secret society known as the American Protective Association. ${ }^{142}$

The American Protective Association was founded by Henry Francis Bowers in 1887. At the time, Bowers resided in the Mississippi River town of Clinton, Iowa, which was a sizable community with a population of roughly ten thousand. The town also contained a Catholic parish, though records indicate that there was little animosity towards local Catholics. This changed, however, in the spring of 1887 when the town's

140 “1922 Balance Sheet," Folder 10, Box G-222, NAACP, LOC.

${ }^{141}$ Greene, Kremer, and Holland, Missouri's Black Heritage, 107-112.

142 Donald L. Kinzer, An Episode in Anti-Catholicism: The American Protective Association (Seattle: University of Washington Press, 1964), 140-141. 
mayor was defeated in the municipal elections. The mayor blamed his loss on Catholic influence within the community, particularly among union workers employed by local lumber companies. Additionally, news that plans for a public high school using land bought from the Catholic parish also startled some residents of Clinton. In between the municipal and school board elections in 1887, a group of men met with Henry Francis Bowers to discuss local affairs. While it was far from being the national organization it would be in the 1890s, the group set in motion plans for an organization rooted in American nativism. ${ }^{143}$

Though it would grow to be one of the largest anti-Catholic organizations in United States History, the American Protective Association was not alone in its goal of attacking "Romanism" within the country while promoting the agendas of native born American Protestants. As Donald Kinzer and other scholars have argued, the period between the 1850s and the 1880s saw the rise and fall of numerous nativist and antiCatholic groups, including the United American Mechanics, American Patriotic League, and National Order of the Videttes, though the APA dominated the larger nativist "movement" that emerged in the 1880s and 1890s. ${ }^{144}$ Beginning in the law office of Henry Francis Bowers, the APA's rise to prominence was slow in the latter half of the 1880s. Bowers had little experience as a recruiter, and success in the early days of the organization was defined by how far he could travel to gain members. That so much was

\footnotetext{
${ }^{143}$ Kinzer, An Episode in Anti-Catholicism, 35-36; David H. Bennett, The Party of Fear: The American Far Right from Nativism to the Militia Movement (New York: Vintage, 1995), 171; John Higham, Strangers in the Land: Patterns of American Nativism, 1860-1925, Second Edition (New Brunswick: Rutgers University Press, 1988), 62-63. For a detailed study of the origins of the APA in Clinton see Jo A. Manfra, "Hometown Politics and the American Protective Association, 1887-1890," The Annals of lowa 55 (1996), 138-166.

${ }^{144}$ Kinzer, An Episode in Anti-Catholicism, 33-35; Higham, Strangers in the Land, 35-105.
} 
placed on his shoulders is not surprising considering he was the main leader, but Bowers' desire to start an anti-Catholic club is rather interesting. In his own words, Bowers later admitted that the root of his concerns about the Catholic Church came from his formative years in Maryland. Though his family left Maryland for Iowa in 1857 when Bowers was an adult, he noted the impact Know Nothing sentiments that circulated through Maryland in the early 1850 s had on his life. His father's German Lutheran background might have also contributed to his feelings toward Catholicism. Throughout his life, however, Bowers, by all accounts, had a good relationship with Catholics in Clinton. ${ }^{145}$

After moving to Iowa, Bowers tried his hand at farming only to suffer through several years of poor results. He then pursued a career in law and eventually moved to Clinton. It seems that law fit him because he eventually won election as a Republican to the offices of Deputy County Clerk and Deputy County Recorder. In 1878, Bowers was appointed as a special aid-de-camp to Governor John Gear. ${ }^{146}$ A decade later, Bowers found himself traveling around the Midwest as the Supreme President of the American Protective Association. Paying his own way most of the time, Bowers' recruiting trips throughout the region slowly raised the APA from obscurity to formidability. By the start of the 1890s, APA councils existed in Iowa, Nebraska, Illinois, Wisconsin, and Michigan. ${ }^{147}$

\footnotetext{
145 Kinzer, An Episode in Anti-Catholicism, 38-40; Bennett, The Party of Fear, 171; Manfra, "Hometown Politics and the American Protective Association," 149.

${ }^{146}$ Kinzer, An Episode in Anti-Catholicism, 38-39; Bennett, The Party of Fear, 171.

147 Kinzer, An Episode in Anti-Catholicism, 54; Bennett, The Party of Fear, 171-172; Manfra, "Hometown Politics and the American Protective Association," 159; Higham, Strangers in the Land, 62-63.
} 
From its earliest days, the APA sought to connect with concerned Americans in several ways. First, its main principles intended to be wide ranging so as to link up with similar nativist and patriotic organizations. The APA asked its members to be loyal to true Americanism and to promote secularism over ecclesiastic powers. ${ }^{148}$ As David H. Bennett has argued, "anti-Irish, anti-Catholic rhetoric was only a part of the American Protective Association's appeal to its constituency [and]... These enduring nativist themes became a touchstone in this age of vast new immigration perhaps in part because they offered a familiar way of dealing with all aspects of the foreign peril...[and] appealed to a disfranchised Protestant middle class experiencing status anxieties and age of social upheaval, people who deeply resented the emergence of a visible Catholic middle class." 149

Additionally, the organization reached out to white women and African Americans at a time when both groups were largely marginalized. While women's involvement in the APA eventually led to the formation of an auxiliary called the WAPA and later support for suffrage, Donald Kinzer has argued that the recruitment of African Americans was merely "window dressing." African Americans were eligible to serve as delegates to the APA's annual convention, but most local councils remained segregated. ${ }^{150}$ Finally, the APA's hierarchical structure of a Supreme President, Supreme Council, and state councils allowed for a system of checks and balances on power. While

${ }^{148}$ Kinzer, An Episode in Anti-Catholicism, 44-46.

149 Bennett, The Party of Fear, 174.

${ }^{150}$ Kinzer, An Episode in Anti-Catholicism, 47-48; Bennett, The Party of Fear, 174; Higham, Strangers in the Land, 86. The APA also tried to establish a Junior Order for members between the ages of 14-21 as well as an international group called the International Protective Association. 
the Supreme President led the APA, the Supreme Council and state councils served as the main governing bodies. As such, they wielded significant power within the organization. This was especially true when delegates at the 1893 national convention ousted Bowers as Supreme President. ${ }^{151}$

The first half of the 1890s was the high point of the APA in the United States. Thanks to a period of cooperation among various nativist groups and the surprising growth of a so-called "patriotic press," the APA emerged as the leader of the nation's nativist movement. ${ }^{152}$ With the continued growth of Catholicism in the United States, combined with the celebration of the World's Columbian Exposition in Chicago which marked the $400^{\text {th }}$ anniversary of Christopher Columbus' discovery of the Americas and the arrival of Archbishop Francesco Satolli as part of Pope Leo XIII's apostolic delegation to the United States, the APA saw a surge in its membership amongst fears of a Catholic takeover of the country. ${ }^{153}$ Newspapers associated with the APA fanned the flames by printing and circulating fake documents purportedly written by Catholic officials discussing plans to overthrow the government and destroy Protestant churches. ${ }^{154}$ Though some Americans assumed that Catholics would soon control the

\footnotetext{
${ }^{151}$ Kinzer, An Episode in Anti-Catholicism, 42-44, 92-93; Bennett, The Party of Fear, 171-177; Manfra, "Hometown Politics and the American Protective Association," 164; Higham, Strangers in the Land, 81.

152 Kinzer, An Episode in Anti-Catholicism, 58-180; Bennett, The Party of Fear, 172-173.

153 Bennett, The Party of Fear, 171-173.

154 Kinzer, An Episode in Anti-Catholicism, 81-83; Bennett, The Party of Fear, 171-176; Higham, Strangers in the Land, 84-85. In reviewing anti-Catholic literature from the 1890s, Bennett cites the reprinting of Maria Monk's convent expose from the 1830 s as well as the emergence of several similar pamphlets and books, particularly related to Margaret Shepherd that detailed alleged atrocities within the Catholic Church. For more information on anti-Catholicism literature in the $19^{\text {th }}$ century see Cassandra Yacovazzi, "So Many Foolish Virgins": Nuns and Anti-Catholicism from Maria Monk to the Know-Nothings (Ph.D. Diss., University of Missouri-Columbia, 2015).
} 
United States and stamp out the nation's Protestant past, such events never occurred. Nevertheless, fear fed the APA.

The APA's greatest period of success occurred in 1893 and 1894. Expanding beyond its Midwestern roots, the organization made major headways in the Northeast and the West. ${ }^{155}$ Though it was non-partisan in political affiliation, the APA tended to back Republican candidates. While the Republicans never allowed the APA's antiCatholicism to dominate the party's platforms and campaigns, it never shied away from leaning on APA members on Election Day. As such, the APA celebrated Republican victories as personal victories for the organization. With Republicans dominating the 1893 and 1894 elections, APA leaders reveled in the group's success in "influencing" state and national politics. ${ }^{156}$

Despite its growth in the Midwest and West Coast, the APA, similar to the Populists of the era, struggled in the South. ${ }^{157}$ Even the appointment of Georgia's John Echols as Supreme President in 1896 did little to improve APA support below the Mason-Dixon Line. ${ }^{158}$ The comparison to the Populists is apt as both groups were trying to influence politics in the 1890 s, and the APA was especially strong in states that also embraced populism. While members of the APA could be found in the Populists' camp, a full-fledged alliance never formed. In fact, opposition to the organization by Kansas'

155 Kinzer, An Episode in Anti-Catholicism, 95-180; Bennett, The Party of Fear, 173; Higham, Strangers in the Land, 80-87.

156 Kinzer, An Episode in Anti-Catholicism, 95-180; Bennett, The Party of Fear, 176-177; Higham, Strangers in the Land, 83-84.

157 Kinzer, An Episode in Anti-Catholicism, 111; Bennett, The Party of Fear, 173-177; Higham, Strangers in the Land, 81.

${ }^{158}$ Kinzer, An Episode in Anti-Catholicism, 112, 218-219; Bennett, The Party of Fear, 173-177. 
Populist government led the APA's state council to take an anti-populist stance. ${ }^{159}$ Nevertheless, the organization's strength in other sections of the country brought it to the height of its power by the middle of the decade. Yet, as the Kansas example indicates, the APA did not go unchallenged.

While the main, and obvious, opponent of the APA was Catholics, perhaps the most well-known figure in the United States to speak out against organization was the Social Gospel minister Washington Gladden. ${ }^{160}$ Gladden became the face of APA opposition because American Catholics were extremely divided over several issues relate to theology during the 1890s. As a result, Catholic opposition to the APA occurred at the local level much more than the national level. Even then, Catholic movements against the group were sporadic at best. ${ }^{161}$ Though Catholics may have been limited in their campaign against the APA, members of the Democratic Party joined them in the fight. While the Democrats were waging their own war of racial intolerance against the nation's black population, the party eagerly courted immigrant voters in many urban areas. Building an electoral alliance with urban Catholics, and attempting to reveal the connection between the APA and the Republican Party, Democrats rallied Catholic voters with a message of religious toleration. ${ }^{162}$

Situated as Iowa's southern neighbor, Missourians became familiar with the APA relatively early in the organization's history. In fact, St. Louis hosted the APA's national

159 Kinzer, An Episode in Anti-Catholicism, 111-112, 141.

${ }^{160}$ Kinzer, An Episode in Anti-Catholicism, 131-132.

161 Kinzer, An Episode in Anti-Catholicism, 85-87, 124-129.

162 Bennett, The Party of Fear, 176-178. 
convention in 1892. ${ }^{163}$ Yet, despite making inroads in the state, including particular strength in St. Louis and Kansas City, the organization could not muster sustained political success as in other Midwestern states. Nevertheless, at the height of the organization's power in 1895, Kansas City's mayor Webster Davis had been elected with APA support, three nativist newspapers were published within the state, and even the St. Louis Catholic newspaper Western Watchman had to admit that the "A. P. A.'s were never as strong in this city as they are at present...every bum politician of both parties has been converted to it.". ${ }^{164}$ The growth of the St. Louis branches of the APA was especially significant due to the large Catholic population within the city as well as the surprising support for the organization from a small portion of local African Americans. ${ }^{165}$

Though the Missouri APA may have obtained positions of power within the state, it had three major critics. First, the state's Catholic newspapers, particularly the Western Watchman, Church Progress, and St. Joseph Catholic Tribune, devoted extensive coverage in their pages to the bigotry and intolerance of the APA. ${ }^{166}$ For a short period of time in 1894, the Catholic Tribune even had a special section in its newspaper

163 St. Louis Post-Dispatch, 7 February 1892.

${ }^{164}$ Kinzer, An Episode in Anti-Catholicism, 85; St. Joseph Herald, 4 April 1894. The three APAlinked nativist newspapers included the Kansas City American, Springfield Protestant American, and St. Louis True American. APA Magazine, December 1895. For comments by the Western Watchman about APA influence in St. Louis see Western Watchman, 16 May 1895.

${ }^{165}$ APA Magazine, July 1895.

166 Kinzer, An Episode in Anti-Catholicism, 31. For examples of APA coverage from these newspapers see issues of the Western Watchman and St. Joseph Catholic Tribune from 1894-1895. 
dedicated to "A.P.A. Notes." 167 The critical response to the APA from the Catholic press, particularly Father D.S.Phelan of the Western Watchman, brought viciousness and vitriol from nativist newspapers. ${ }^{168}$ In addition to the Catholic press, the APA also found a worthy opponent in Governor William J. Stone. Elected in 1892, Stone served out his term at the height of the APA's activity in the state and he was not silent about his opposition to the organization. At the state Democratic convention in 1894, Stone pushed hard for an anti-APA plank in the party's platform and later gave a rousing speech that denounced the organization. ${ }^{169}$ Across the political aisle, prominent Catholic Republican Richard Kerens joined Stone in his opposition. Though the Republican Party tended to receive the support of the APA, Kerens worked hard to separate the state party from the organization. ${ }^{170}$ His attempts at a full separation met with limited success, but Kerens' efforts, combined with Stone's work among the Democrats, nevertheless prevented the APA from having any sort of role in state politics, outside of municipal and local campaigns. ${ }^{171}$

While events in Missouri suggest that unified efforts against the APA could produce successful repudiation, the organization's downfall was closely tied to national politics and internal factionalism. Most importantly, though the organization built a large

${ }^{167}$ St. Joseph Catholic Tribune, 21 April 1894, 28 April 1894. The Catholic Tribune also informed its readers in 1893 that APA stood for "a pack of asses." St. Joseph Catholic Tribune, 25 November 1893.

${ }^{168}$ APA Magazine, June 1895, July 1895, September 1895, October 1895, April 1896, September 1896, February 1897, March 1897, April 1897.

${ }^{169}$ St. Joseph Catholic Tribune, 9 June 1894, 6 October 1894,

170 Kinzer, An Episode in Anti-Catholicism, 143-144; St. Joseph Catholic Tribune, 18 August 1894, 25 August 1894.

${ }^{171}$ Kinzer, An Episode in Anti-Catholicism, 201-202. 
membership based on opposition to Catholics, anti-Catholicism never became a prominent political issue in the 1890 s. ${ }^{172}$ Candidates for office could express antiCatholic sentiments and run on issues that many voters associated with Catholicism, particularly public education and immigration restrictions, but policies connected to currency and the economy ruled the day. As both the Republicans and Democrats fought over alliances with the Populists, the Republicans pushed the APA farther and farther to the fringe. ${ }^{173}$

Additionally, opposition to the APA's leadership grew within the membership ranks as the organization floundered in the middle point of the decade. By 1896, with William McKinley showing no deference to the APA as the Republicans' presidential candidate, the Supreme President was ousted at the organization's annual convention. ${ }^{174}$ The group continued to struggle as the $19^{\text {th }}$ century closed, even re-appointing Henry Francis Bowers as Supreme President in an attempt to right the ship. ${ }^{175}$ No longer an organization with nation-wide strength, the APA continued at the local level in portions of the Midwest until World War I. While some of its members eventually merged with elements of the Ku Klux Klan nationwide in the 1920s, the American Protective Association did not experience a revival within the Invisible Empire. ${ }^{176}$

172 Kinzer, An Episode in Anti-Catholicism, 140; Bennett, The Party of Fear, 178.

${ }^{173}$ Kinzer, An Episode in Anti-Catholicism, 181-239; Bennett, The Party of Fear, 176-178.

${ }^{174}$ Kinzer, An Episode in Anti-Catholicism, 181-239; Bennett, The Party of Fear, 176-178; Higham, Strangers in the Land, 85-87.

${ }^{175}$ Kinzer, An Episode in Anti-Catholicism, 236; Bennett, The Party of Fear, 176-178; Manfra, "Hometown Politics and the American Protective Association," 164.

${ }^{176}$ Kinzer, An Episode in Anti-Catholicism, 230-249. 
While the American Protective Association faded from existence by the early $20^{\text {th }}$ Century, the anti-Catholicism that had helped it rise to tremendous heights remained entrenched in American society. Not surprisingly, several anti-Catholic publications continued on after the APA with the goal of promoting patriotism and Americanism through the press. One of the largest, and arguably most successful, anti-Catholic newspapers of this period was the Menace. Published in tiny Aurora, Missouri, the Menace set out from the very beginning to inform readers that American values and institutions, such as the public school system, were "the antidote for papal poison." 177 The newspaper began in 1911 under the ownership of Wilbur Franklin Phelps and Thomas Earl McClure. ${ }^{178}$ Though it struggled at first to corner the market on antiCatholic publications, the weekly newspaper grew quickly, and by 1915 it claimed a total of 1.5 million subscribers. ${ }^{179}$ It grew so successful that the railroad lines and post office in Aurora had to expand to accommodate the newspaper's printing demands. ${ }^{180}$

With Phelps and McClure at the helm, and Rev. Theodore C. Walker and Marvin Brown handling editorial duties, the Menace grew to national prominence. In addition to its main newspaper, the Menace Publishing Company also advertised anti-Catholic books and pamphlets as well as promoting lecture series on the subject. ${ }^{181}$ By the dawn of

177 The Menace, 11 November 1911.

178 Matt Pearce, "A Century Ago, A Popular Missouri Newspaper Demonized a Religious Minority: Catholics," Los Angeles Times, December 9, 2015, accessed July 14, 2017, http://www.latimes.com/nation/la-na-catholic-scare-20151209-story.html; The Menace, 11 November 1911.

179 Nordstrom, Danger on the Doorstep: Anti-Catholicism and American Print Culture in the Progressive Era (Notre Dame: University of Notre Dame, 2006), 10, 56, 183; Pearce, "A Century Ago."

180 Pearce, "A Century Ago."

181 Pearce, "A Century Ago." 
World War I, the Menace had turned Aurora into the "World's Headquarters for AntiPapal Literature."182 Such success did not go unnoticed. Several other anti-Catholic publications devoted portions of their pages to the work of the Menace. Even Tom Watson, the Populist politician-turned-white supremacist provocateur, wrote glowingly of the newspaper. ${ }^{183}$ Despite the positive reviews, the Menace was not without its objectors. Catholics, particularly those aligned with the Knights of Columbus, voiced opposition to the newspaper. ${ }^{184}$ Perhaps one of the newspaper's biggest critics was also one of its primary targets. As he had been during the height of the APA and its "patriotic" press, Father D.S. Phelan frequently drew scorn from the Menace for his comments in the pages of his newspaper, Western Watchman, on claims of papal conspiracy and the legacy of anti-Catholicism in the United States. ${ }^{185}$ To the editors of the Menace, Phelan was a "bitter and relentless enemy" who served the Catholic Church as the "MOUTH-PIECE OF THE HIERARCHY."186

Phelps and McClure tried to counter these protests by arguing that their publication did not oppose the religious beliefs of Catholics, only the Catholic Church's

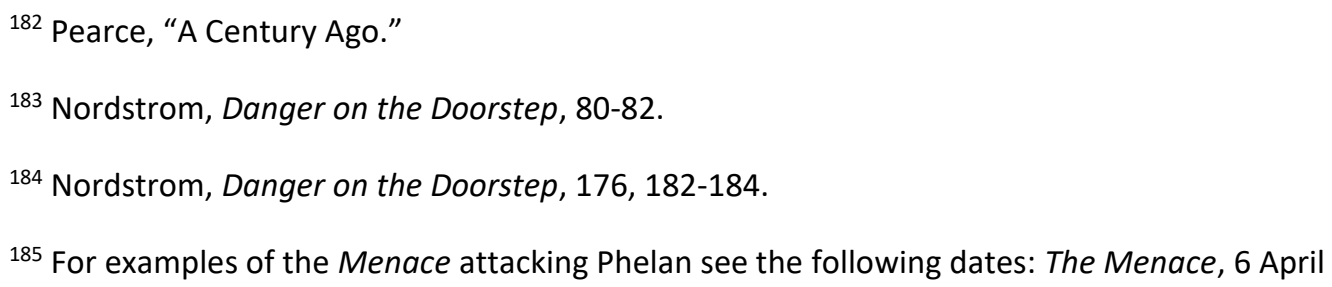
1912, 31 August 1912, 28 September 1912, 5 October 1912, 12 October 1912, 14 December 1912, 11 January 1913, 3 May 1913, 10 May 1913, 17 May 1913, 14 June 1913, 19 July 1913, 2 August 1913, 20 August 1913, 18 October 1913, 24 January 1914, 28 March 1914, 2 May 1914, 9 May 1914, 6 June 1914, 20 June 1914, 27 June 1914, 10 October 1914, 21 November 1914, 5 December 1914, 19 December 1914, 2 January 1915, 30 January 1915, 20 March 1915, 15 May 1915, 25 June 1915, 31 July 1915, 21 August 1915, 4 September 1915, 18 September 1915, 2 October 1915, 15 July 1916.

186 The Menace, 28 September 1912, 2 October 1915. 
alleged interference in American politics. ${ }^{187}$ Nevertheless, weekly articles suggesting that the Pope planned to take over the United States while women were locked away in convents at the mercy of villainous priests were enough for Catholics to push the Postmaster General to suppress delivery of the newspaper. These efforts met with limited success, though the Menace was banned in Canada. ${ }^{188}$ Eventually, the Knights of Columbus, and other Catholic groups, sued the Menace Publishing Company for libel and slander. ${ }^{189}$ Hoping to silence the publication, or at the very least burden it with legal fees, Catholics were disappointed when a federal court in Joplin, Missouri, ruled in favor of the Menace in 1916. Upon returning to Aurora at the conclusion of the trial, the publishers found a crowd of well-wishers to greet them. ${ }^{190}$

The courts did not put the Menace out of business, but violence nearly did at the end of the 1910s. Around the time of the federal slander trial, a series of mysterious explosions rocked Aurora. While the explosions did damage the newspaper's building, printing soon resumed as normal. ${ }^{191}$ When the United States entered World War I the following year, however, the Menace saw a steep decline in its subscriber list. The newspaper tried to rebound by tying Catholicism to the causes of the war, but the

\footnotetext{
${ }^{187}$ Nordstrom, Danger on the Doorstep, 176, 182-184.

188 Nordstrom, Danger on the Doorstep, 114-117, 129-142, 176, 182-184; Pearce, “A Century Ago."

${ }^{189}$ Christopher Kauffman, Faith and Fraternalism: The History of the Knights of Columbus (New York: Simon \& Schuster, 1992), 268-289.

190 Nordstrom, Danger on the Doorstep, 1-2, 76-77, 184-185; Pearce, “A Century Ago." In 1916, the Menace was sold to the Free Speech Defense League which managed several other "patriotic" newspapers, though the Menace Publishing Company remained the publisher of the newspaper. The Menace, 20 May 1916.

191 Nordstrom, Danger on the Doorstep, 181-182; The Menace, 5 August 1916.
} 
subscribers did not return in the same volume as before. ${ }^{192}$ In addition to its wartime decline, the Menace suffered another explosion in 1919. This time the damage caused the entire printing plant to burn down, though it is unclear if the incident was the work of an objector or accidental. The second fire brought an end to the Menace. It ceased publication at the end of $1919 .{ }^{193}$

A few months after the fire, Gilbert O. Nations and Billy Parker established the New Menace. ${ }^{194}$ Both men had previously been associated with the Menace Publishing Company and the old Menace, with Nations listed as Vice President and Parker as Secretary Treasurer/Business Manager as of late 1919. ${ }^{195}$ Though the original printing plant was destroyed, Nations and Parker kept the New Menace in southwest Missouri. While the New Menace could not recapture the success of its predecessor, ceasing publication in the early 1930s; the new owners became quite prominent in the 1920 s nativist movement and held close ties with the Ku Klux Klan. Parker toured the country touting anti-Catholicism and the New Menace. Nations was selected as the presidential nominee of the newly formed American Party in 1924, and worked with Klan affiliated publications including the Fellowship Forum and The Protestant. ${ }^{196}$

The example of Gilbert Nations and Billy Parker highlights the close connection between early twentieth century bigotry and the rise of the second $\mathrm{Ku}$ Klux Klan, but as this chapter demonstrates, the roots of racial and religious intolerance within the Invisible

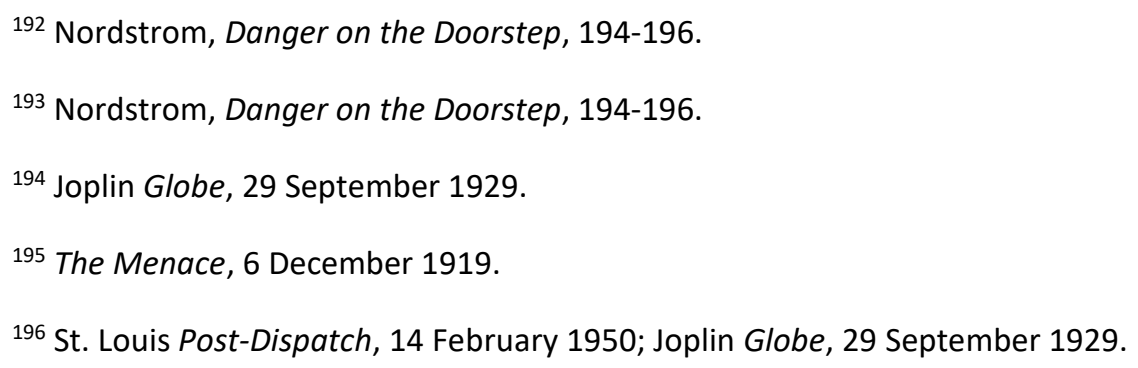


Empire can be traced back much further. From the earliest slave laws based in the Code Noir, Missourians established a racial hierarchy that applied second class citizenship to those deemed non-white. Additionally, though they were not overwhelmingly successful, antebellum politicians associated with the American Party, as well as their late $19^{\text {th }}$ century counterparts in the American Protective Association, tried to restrict the rights of foreign-born, Jewish, and Catholic residents of the state. Finally, while not as entrenched as the de jure segregation of fellow southern states, the attempts by members of both the Democratic and Republican parties to pursue Jim Crow laws promoted a culture that embraced lynching and de facto segregation in urban centers and rural communities. Combined together, these repressive attempts reveal the long legacy of racial and religious intolerance in the state. However, as this chapter shows, and will be discussed more in later chapters, those directly impacted by these examples of bigotry and intolerance did not endure them passively. Instead, these groups, particularly Catholics and African Americans, struck back against their critics and launched a period of active resistance in the $19^{\text {th }}$ and early $20^{\text {th }}$ centuries. This activism continued in to the 1920 s and directly challenged the rise of the second Ku Klux Klan. 


\section{Chapter 2: "Silence gives consent"}

Frank O. Crippen arrived in St. Louis, Missouri, with big plans in May 1921. As the Grand Goblin of the Ku Klux Klan's Domain of the Mississippi Valley, Crippen was responsible for the further growth of the organization in the Upper Midwest, including Missouri, Kansas, Nebraska, Iowa, Minnesota, and the Dakotas. Yet despite Crippen's claims that the Klan brought "intensified patriotism" to St. Louis and worked to "foster Americanism and uphold law," some residents were skeptical. ${ }^{1}$ "We found ourselves face to face with a new order of things," declared the African American newspaper the St. Louis Argus, "in announcing their presence here, the Grand Goblin of this Klan said it was not the organization of fifty years ago, which had for its purposes murder, arson, terrorism, intimidation and many other barbarous practices; but that it had more lofty purposes." Citing the alleged atrocities of Klansmen in Texas, the Argus argued that "no one will believe these statements."2

In addition to the Argus, the local branch of the National Association for the Advancement of Colored People and the Church Progress, a Catholic newspaper based in the city, both issued lengthy commentaries about the Klan's arrival in St. Louis. Responding to a letter in the St. Louis Times from an alleged local Klansmen, the NAACP declared that "St. Louis has no need of such a movement in its life...the Grand 'Gobler' should be told to 'move on', and if he is slow, a little force should be gently

\footnotetext{
${ }^{1}$ St. Louis Star, 11 May 1921; St. Louis Post-Dispatch, 11 May 1921; Joplin Globe, 12 May 1921.

2 St. Louis Argus, 20 May 1921.
} 
applied, march him down to Eads Bridge and point to [Illinois] with a police club and made to 'go'."' The Church Progress advised its readers to follow the examples exhibited by anti-Klan residents of Illinois and Texas in suppressing the Klan. If such activism was undertaken nationwide, the Ku Klux Klan "will soon be what it ought to be, namely, an unsavory memory."

As the Ku Klux Klan slowly grew from its Atlanta roots around 1921, newspapers across the country took note of the recruiting efforts of the organization. For most newspapers, they took on a role of mere reporters of Klan activity. Klan recruiters usually paid for advertisements to run in local newspapers regarding upcoming events in the hope of attracting both a large crowd and a positive follow-up story afterwards. In most cases, the press obliged the Klan and ran short articles on these events with little commentary of praise or denouncement. Yet, out of this regular press coverage emerged a collection of newspapers that were quite vocal in their opposition to the Klan. Whether publishing articles on alleged Klan atrocities in their pages, or prominently placing editorials that denounced the rhetoric and recruitment of Klansmen, these newspapers undertook the most influential element of early anti-Klan activism and proved to be a formidable foe of the Invisible Empire. Likewise, the press' intervention in regards to the Klan successfully pushed politicians, community leaders, and private citizens, particularly in Missouri, to speak out about the hooded order. Not surprisingly, many anti-Klan figures followed the advice of the St. Louis Argus that "silence" regarding the Invisible Empire gave "consent" to its activities.

\footnotetext{
${ }^{3}$ St. Louis Argus, 20 May 1921.

${ }^{4}$ Church Progress, 26 May 1921, 23 June 1921.
} 
This chapter examines the efforts of anti-Klan activists, particularly in the press, to curtail the earliest recruiting attempts made by the Ku Klux Klan in Missouri in 1921 and 1922. Though recruiting success would be limited for the Klan in these years, the Invisible Empire nevertheless established a "beachhead" in the border communities of the state, particularly St. Louis and Joplin. At the same time, though, the Klan, and its recruiters, faced high levels of opposition from anti-Klan newspapers like the St. Louis Post-Dispatch, St. Louis Argus, Kansas City Catholic Register, and Kansas City Call; key state politicians like Governor Arthur Hyde and Unite States Senator James A. Reed; and Missouri residents who felt that there was no place for the hooded order in their communities.

When Klan officials first set their sights on states to "klux," they usually began in major cities. From there, they worked their way through medium-sized cities, county seats, and finally, small towns and villages. ${ }^{5}$ It appears, however, that such tactics were different for Missouri. Records show that Klan officials began to publicly recruit St. Louis in the late spring of 1921, but there is little indication that similar recruitment occurred in Kansas City until much later in the year. Likewise, the first public Klan activity in the state appeared in the southwestern Missouri town of Joplin, not St. Louis. If southwestern Missouri served as the gateway for the Klan to enter the state, and Joplin, a city of roughly 30,000 people in 1921, as its first major hub, how did the Invisible Empire get there in the early 1920s? The answer lies in George C. McCarron.

George C. McCarron, originally from Houston, Texas, came to Oklahoma City in 1921 to help with Klan recruitment in Oklahoma. His role within the state was as King

\footnotetext{
${ }^{5}$ Alexander, The Ku Klux Klan in the Southwest, 44.
} 
Kleagle, or supervisor of recruitment. Historian Charles Alexander has found that Oklahoma did not experience widespread Klan recruitment until early $1921 .^{6}$ This would have been at roughly the same time as recruitment began in southwest Missouri. By the spring of 1921, Klan chapters started in Oklahoma at Tulsa and Muskogee, both within one hundred miles of the Missouri border. ${ }^{7}$ Unfortunately, records that indicate that McCarron authorized his Klan recruiters to head northeast into Missouri are unavailable. But, McCarron, himself, soon made his home in the state, and by 1924 was listed as the Imperial Klan Representative for Missouri, Kansas, and Nebraska. ${ }^{8}$ With this is mind, it seems highly likely that McCarron's success in "kluxing" in Oklahoma convinced Klan officials that his talents were needed farther north as well.

Though it is unknown where the Klan originally organized within Missouri, Joplin served as one of the first major communities to receive the hooded order. What would become Ozark Klan No. 3 began as an intense month-long recruitment of the citizens of the city in March 1921 when kleagles sent a packet of information about the group to the Joplin Globe. ${ }^{9}$ The Globe, one of the largest newspapers in southwest Missouri, served as the primary conduit of recruiting information for the Klan in its earliest days. The newspaper ran Klan advertisements for events, recruiting flyers, and the latest information on rumors tied to the order. In doing all of this, it is noteworthy that the Globe never ran an official editorial supporting or denouncing the Klan's efforts

\footnotetext{
${ }^{6}$ Alexander, The Ku Klux Klan in the Southwest, 43-44.

${ }^{7}$ Alexander, The Ku Klux Klan in the Southwest, 44. Alexander also lists Oklahoma City, Lawton, and Enid as other major communities in Oklahoma to establish Klan chapters in 1921.

8 Jefferson City Democrat-Tribune, 1 May 1924.

${ }^{9}$ Joplin Globe, 8 March 1921.
} 
in Joplin. Among the Klan-based information that the Globe reprinted was the "Ku Klux Creed," an article originally published in the Klan-affiliated Searchlight entitled "The Ku Klux Spirit," a short history of the Klan originally published in Atlanta, a photo of Klansmen at a Georgia meeting, and an advertisement asking for "100 Per Cent Americans...None Others Need Apply." ${ }^{10}$ The last advertisement appeared in the newspaper's advertising section at various times throughout the month of March. ${ }^{11}$

Beyond its advertisements in the local press, the Klan also attempted to court the business and professional men of Joplin through a series of questionnaires. These questionnaires, which were a standard feature of Klan recruitment, asked potential members about their backgrounds. Questions ranged from "Do you believe in white supremacy?" and "Do you believe in the principles of a pure Americanism?" to "Color of eyes? Hair? Weight? Height?". While the questionnaires asked the recipient "not to reveal the fact that they received such literature," it is obvious that the pamphlets were well received by members of Joplin's business class because only days after the questionnaires were initially sent out, Newman's, one of the largest department stores in the city, published an advertisement in the Globe thanking the Klan for the recent communication and promising to act upon the information provided. ${ }^{12}$

Near the end of March, the Klan organized an official meeting for all interested businessmen in Joplin. Close to two hundred men crowded the rooftop garden of the Connor Hotel to hear about the principles of the organization as well as key points of

\footnotetext{
${ }^{10}$ Joplin Globe, 8 March 1921, 11 March 1921, 12 March 1921.

${ }^{11}$ Joplin Globe, 12 March 1921, 22 March 1921, 24 March 1921.

${ }^{12}$ Joplin Globe, 10 March 1921, 11 March 1921.
} 
concern for the Klan, including government corruption and the Catholic Church. Turning to issues in Missouri, the speaker denounced the decision by the St. Louis Chief of Police to bar newspaper boys from "crying" the headlines of Henry Ford's Dearborn Independent, a newspaper accused of anti-Semitism, on public streets. ${ }^{13}$ The speaker then addressed the key reason he was in town: why Joplin was in need of a Klan chapter. For this last point, the speaker listed three primary reasons. First, there were a number of allegedly immoral boarding houses in the city. Second, citing protection of white womanhood, he raised concerns that white women were recently seen in predominantly African American resorts. Third, the city lacked a Protestant hospital. In bundling these various issues together, the Klan then sent the audience home with membership applications. ${ }^{14}$ Within a few weeks, an advertisement in the Globe announced that "[ $[$ ] he $\mathrm{Ku}$ Klux Klan Is an Established Fact in Joplin... it already numbers among its membership scores of the best citizens." ${ }^{15}$ Amongst the advertisement's discussion of recruiting success, the Klan also left a warning for those who opposed it:

Do not fool yourself nor be misled nor deceived by the blasphemous talk you hear concerning this institution by those who do it from ignorance or by those who are lawless and corrupt. The Klan knows all about this talk. The man sitting by you on the street car may be a Klansman; the clerk who waits on you; the man who hands out your money at the bank; the man who sits by you at the ball game. They are everywhere. Their ears are open and they find out why you are talking thus. ${ }^{16}$

\footnotetext{
${ }^{13}$ Joplin News-Herald, 21 March 1921; Jefferson City Democrat-Tribune, 21 May 1921.

${ }^{14}$ Joplin News-Herald, 21 March 1921.

${ }^{15}$ Joplin Globe, 10 April 1921.

${ }^{16}$ Joplin Globe, 10 April 1921.
} 
While the Ku Klux Klan formed with little opposition in Joplin, this was not the case for other parts of Missouri due to the reaction of some state newspapers to the organization. As has been shown with Joplin, the local Globe offered little resistance to the Klan as it published official organizational literature. Yet, even before the arrival of the Klan in the state, Missouri residents had kept a close eye on the growth and development of the order throughout the United States because newspapers regularly published information about alleged Klan activity. While most articles focused on the modern Klan and the relationship to its Reconstruction predecessor, the subject of vigilantism soon became a recurring theme in many Klan-related stories. A number of atrocities allegedly tied to the Klan in Texas, particularly the whipping of an African American man and the branding of "K.K.K." upon his face, became feature stories throughout Missouri. ${ }^{17}$ "The Lone Star State," the Kansas City Star noted, "may take arms against the seas of troubles its modern 'Ku Klux' has stirred up.”18

In the wake of violent acts supposedly committed by the hooded order, including a whipping by masked men in Missouri's Polk County, some newspaper editors questioned the motives of the revived Klan. ${ }^{19}$ Labeling the Klan as a "Dangerous Organization" during its extensive coverage of atrocities committed by hooded mobs in

\footnotetext{
17 Southeast Missourian, 2 April 1921; Fulton Daily Sun, 2 April 1921; Fulton Gazette, 7 April 1921; Columbia Missourian, 2 April 1921; St. Louis Argus, 20 May 1921; Kansas City Star, 13 May 1921, 22 July 1921, 23 July 1921, 24 July 1921, 26 July 1921, 31 July 1921; Kansas City Journal, 18 July 1921, 20 July 1921, 21 July 1921, 23 July 1921, 26 July 1921, 27 July 1921, 28 July 1921, 29 July 1921, 30 July 1921,31 July 1921; Kansas City Catholic Register, 7 July 1921, 21 July 1921, 28 July 1921.

${ }^{18}$ Kansas City Star, 31 July 1921.

${ }^{19}$ St. Louis Post-Dispatch, 6 July 1921, 7 July 1921; St. Louis Argus, 15 April 1921; Church Progress, 7 July 1921, 14 July 1921; Western Watchman, 27 May 1921, 22 July 1921, 29 July 1921, 12 August 1921, 26 August 1921; Southeast Missourian, 22 July 1921; Columbia Missourian, 9 April 1921,20 July 1921, 22 July 1921, 29 July 1921; Joplin Globe, 9 June 1921, 23 July 1921; Fulton Daily Sun, 22 January 1921, 20 June 1921; Jasper County Democrat, 24 June 1921.
} 
Texas, the Kansas City Catholic Register declared that "the secret methods of the organization make it even more cowardly than those who would lynch suspected black men."20 The newspaper also encouraged the work of various anti-Klan groups in battling the "Unchristian and Un-American" activities of the Invisible Empire of Texas. ${ }^{21}$ The Kansas City Journal argued that "Ku Kluxism cannot be tolerated by right-thinking Americans." 22 The Jewish Voice advised its readers that if the Klan was successfully broken up the masks should be removed from its leaders' faces and their regalia "consigned for all times to the bon fire of oblivion." 23 The Church Progress went so far as to call for the Klan to be cleaned-up and cleaned-out. ${ }^{24}$ In encouraging such "purifying" steps, the St. Louis Post-Dispatch called on the Klan to change its name due to its association with lawlessness and terrorism. But, noting that Klan vigilantism had bred vigilantism from other groups, the Post-Dispatch demanded that the organization disband. $^{25}$

To counter claims by the press that acts of violence and vigilantism were undertaken solely by those donning the mask of the Klan, Imperial Wizard William Simmons took out a full page advertisement entitled "To All Lovers of Law, Order, Peace and Justice, and to All the People of the United States" in the St. Louis GlobeDemocrat. Simmons did not deny that rogue members of the Klan were performing a

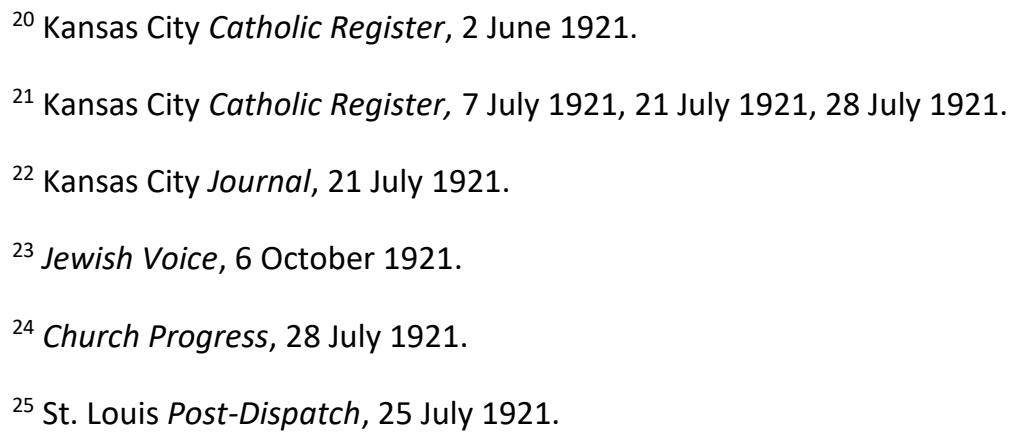


small portion of the violence; but, he asserted that such acts violated the code of conduct of Klansmen and that those not associated with the order were also doing some of the violence. Time and again, Simmons referred back to the Klan's role in protecting American citizens from vigilantism and lawlessness, not inflicting it upon them. ${ }^{26}$ In concluding his lengthy letter, Simmons left final judgement to the American people:

If we are all that our enemies charge or even one-fourth as wicked as claimed, American has nothing to fear from this Organization, for it will perish. On the other hand, if we are lied about by those who are unworthy and who are not pure Americans at heart...the time will come when all their falsehoods and slanderous statements will react on them, and the Knights of the Ku Klux Klan will come into its own and take its place in the hearts of real Americans, where its founders intended it should, as the one greatest force in America to guarantee to all men that this country shall forever be what its founders intended, THE LAND OF THE FREE AND THE HOME OF THE BRAVE, wherein all men, regardless of race, color or creed, can live in peace and happiness, enjoying the greatest amount of liberty and justice in any country in the world. ${ }^{27}$

Simmons followed his open letter to St. Louis residents with a visit to the city in September 1921. Though the local Klan had struggled to obtain the proper finances to stage a large event for the Imperial Wizard at the Moolah Temple, a successful drive to secure funding had raised just enough by the time of his speech. ${ }^{28}$ Simmons was introduced to St. Louisans as a "great American apostle of what George Washington and [Thomas] Jefferson and [Benjamin] Franklin taught." As a band played the "Star Spangled Banner," Simmons rose from his seat and gazed out over a crowd of roughly

\footnotetext{
${ }^{26}$ St. Louis Globe-Democrat, 13 August 1921.

${ }^{27}$ St. Louis Globe-Democrat, 13 August 1921.

${ }^{28}$ St. Louis Post-Dispatch, 24 September 1921.
} 
one thousand interested citizens and 300 local Klansmen. During his time on stage, Simmons spoke in defense of his beloved Klan. He denounced the violence taking place in parts of the United States and questioned those who tried to link the Klan to such acts. To him, the Klan was just like any other fraternal organization. His message to the possible recruits in the audience was one of patriotism, morality, and one hundred percent Americanism. ${ }^{29}$ The meeting was not without controversy, though, as the owners of the Moolah Temple received heavy criticism for renting the facility for a Klan event. ${ }^{30}$

William Simmons' St. Louis speech came at a critical time for the local Klan. At the time of Simmons' arrival, Grand Goblin Frank Crippen claimed that St. Louis had roughly 3500 Klansmen who had been meeting at secret locations throughout the city under the name "Missouri Business Men's League."31 Yet, despite this growth, the city's press continued to criticize the organization. In addition to the Post-Dispatch, Star, Argus, Western Watchman, and Church Progress, which had all devoted numerous editorial pages to alleged Klan atrocities during the previous summer, two Jewish publications, Modern View and the Jewish Voice, began to issue condemnations of the hooded order's vigilantism. However, though the Jewish Voice denounced the organization as a fourth branch of government that was unneeded and Modern View expressed relief in the exclusion of Jews from the Klan as "equivalent to being barred

${ }^{29}$ St. Louis Star, 25 September 1921; St. Louis Globe-Democrat, 25 September 1921; St. Louis Post-Dispatch, 25 September 1921.

${ }^{30}$ St. Louis Post-Dispatch, 26 September 1921.

${ }^{31}$ St. Louis Post-Dispatch, 6 September 1921; Crippen claimed in August that the Klan had enrolled 400 members in St. Louis and most meetings took place at the Planters' Hotel. St. Louis PostDispatch, 15 August 1921. 
from leprosy or smallpox," neither newspaper felt that the hooded order was openly antagonistic to the Jewish people. ${ }^{32}$

Simmons' speech occurred at a critical time for the national Klan as well. In September, the New York World commenced a lengthy expose on the organization. Reprinted in newspapers throughout the United States, including the St. Louis PostDispatch, the expose focused on sensational information related to the Klan, its finances, recruiting tactics, and rituals. While outlining the basic tenets of the Klan, the World also focused on the violence associated with the order in Texas and parts of the South.

Finally, the expose included denouncements of the Klan by government officials, religious leaders, and former Klansmen. ${ }^{33}$ Most prominently Henry P. Fry, a former kleagle who later authored a book about his experiences in the Klan - The Modern Ku Klux Klan - labeled the organization anti-Catholic and anti-Semitic and explained that such intolerance influenced his decision to leave the Invisible Empire. ${ }^{34}$ One of the main goals of the World expose was to bring the secrets and outrages of the Klan to a national audience. The hope was, as the St. Louis Post-Dispatch noted, that:

Publicity would wither it as a cavernous weed is withered by the midday sun...How any sensible man, after reading the highfalutin flubdub [sic] of its sacred Kloran, the burlesque of its ritual and the list of its officers, from Imperial Wizard through the Klakard and the Kludd, the Kleagle and the Klarago, can hold his membership is beyond the range of sane judgement...The danger of the organization lies in its playing upon the prejudices and

\footnotetext{
${ }^{32}$ St. Louis Post-Dispatch, 13 September 1921; Jewish Voice, 1 September 1921.

${ }^{33}$ Lay, Hooded Knights on the Niagara, 4, 40-41; Chalmers, Hooded Americanism, 35-36; Wade, The Fiery Cross, 160-161; Jenkins, Steel Valley Klan, 5-6; St. Louis Post-Dispatch, 6 September 1921, 7 September 1921, 8 September 1921, 12 September 1921, 13 September 1921, 14 September 1921, 15 September 1921, 16 September 1921, 17 September 1921, 18 September 1921, 19 September 1921.

${ }^{34}$ St. Louis Post-Dispatch, 7 September 1921; Baker, Gospel According to the Klan, 34-35.
} 
passions of the ignorant and thoughtless and thus inciting violence, but even the ignorant, in light of the exposure of the flubdubbery [sic] and spoils of the "Invisible Empire," ought to see the folly of membership. The mystery which is an alluring appeal to the "joiners" has vanished, the mask is off and the grotesque devil is visible. ${ }^{35}$

The St. Louis Post-Dispatch's reprinting of the World expose brought it acclaim from city residents opposed to the Invisible Empire. After publishing the names and addresses of Missouri Klan officers, several groups, including the Knights of Columbus, publicly thanked the editors of the Post-Dispatch for the expose series. ${ }^{36}$ Sharing the sentiment, one resident declared in a letter to the editor that "the Post-Dispatch is earning the thanks and good will of true-blue American citizens by its expose of Ku Klux Klan Inc....Knocking 'em [sic] cold is a P-D habit." 37 Though the Post-Dispatch reaped the benefits of reprinting the expose, other newspapers soon began to emulate the World's tactics against the Klan. Both the Jewish Voice and Church Progress published excerpts from the World and thanked the newspaper for its efforts to put the Klan "on the run." 38 In Columbia, the Missourian sent its "Inquiring Reporter" out into the community to

${ }^{35}$ St. Louis Post-Dispatch, 13 September 1921.

${ }^{36}$ St. Louis Post-Dispatch, 8 September 1921, 14 September 1921, 4 October 1921. The Missouri Klan officers identified were Frank Crippen (Grand Goblin), G.A. Glasscock (King Kleagle), Casey Jones (King Kleagle), L.H. Scott (Kleagle), A. Fischer Jr. (Kleagle), W.H. Thompson (Kleagle), R.G. Allen, Jr. (Kleagle).

${ }^{37}$ St. Louis Post-Dispatch, 16 September 1921.

38 Jewish Voice, 22 September 1921; Church Progress, 22 September 1921; St. Louis PostDispatch, 12 September 1921. 
gauge local reaction to the Klan. Of the five respondents polled, three condemned the Klan and two expressed reserved praise for it. ${ }^{39}$

While the St. Louis press generally expressed anti-Klan sentiments, no newspaper targeted the hooded order more than the Argus. As early as January 1921, roughly four months before Frank Crippen stepped foot in the city, the Argus felt it necessary to issue a strong warning against the Klan. There was "no room for the Ku Klux Klan," the newspaper argued, and if the order did continue to grow "the Negroes of today will meet the white robed wizards of the night with a different spirit to what their fathers met it fifty years ago." ${ }^{40}$ When it was rumored that William Simmons might visit St. Louis on a grand tour of the United States, the Argus suggested that the African American community "fight fire with fire... a coat of tar and a coat of feathers will be too good for him."41

The Argus' role as the city's chief Klan fighter was rooted in the beliefs of its owner and leader, J.E. Mitchell. Born in Alabama at the end of Reconstruction, Mitchell spent much of his early life in the South. After serving in the Spanish-American War and the later Philippines War, he moved to St. Louis in 1904 where his brother William soon joined him. After a brief period of work in the service industry, the Mitchell brothers entered the insurance business with J.E. soon becoming the general manager of the Western Union Relief Association. ${ }^{42}$ The Argus originally began as a newspaper

\footnotetext{
${ }^{39}$ Columbia Missourian, 26 September 1921.

40 St. Louis Argus, 21 January 1921.

${ }^{41}$ St. Louis Argus, 18 February 1921.

42 Debra Foster Greene, Published in the Interest of Colored People: the St. Louis Argus Newspaper in the Twentieth Century (Ph.D. Diss., University of Missouri-Columbia, 2003), 9-12.
} 
affiliated with the organization; yet, despite ties to several prominent African American men in St. Louis, the WURA went out of business after only a few short years. Opting to continue with the publication, the Mitchell brothers turned what would become the Argus into a weekly newspaper serving the city's black population. ${ }^{43}$ As historian Debra Foster Greene has noted, the Argus' slogan that it was "published in the Interest of Colored People" allowed it to connect to its St. Louis readership and quickly become the city's preeminent African American newspaper. ${ }^{44}$

Due to his prior work in the Western Union Relief Association, J.E. Mitchell held a prominent place within St. Louis' African American population. From this perch, Mitchell used the Argus to spread his views on the need for uplift in the city. He preached a gospel that adhered to that of Booker T. Washington, but he also expressed some support for W.E.B. DuBois. ${ }^{45}$ In politics, however, he refused to stray far from the Republican Party. The Argus was a Republican newspaper, and stayed that way until the Franklin Roosevelt administration. As a Republican newspaper, the Argus kept close tabs on the actions of local politicians within the party and was frequently critical when city officials kowtowed to discriminatory and segregationist policies. ${ }^{46}$ A favorite target was Mayor Henry Kiel who, despite promises to do so during his campaign, did not appoint African Americans to key position in city government. ${ }^{47}$

\footnotetext{
${ }^{43}$ Greene, Published in the Interest of Colored People, 12-14.

${ }^{44}$ Greene, Published in the Interest of Colored People, 12-24.

${ }^{45}$ Greene, Published in the Interest of Colored People, 15-16.

${ }^{46}$ Greene, Published in the Interest of Colored People, 14, 32-70.

${ }^{47}$ Greene, Published in the Interest of Colored People, 45.
} 
In addition to holding city Republicans accountable, the Argus also closely monitored the activities of the Klan in St. Louis. In fact, Debra Greene argues that the Argus "spearheaded the African American community's struggle for lawful protection against the activities and actions of the Ku Klux Klan." ${ }^{48}$ After Frank Crippen's claim that members of City Hall and the local police force had joined the Klan drew the ire of many St. Louis residents, the Argus demanded that city officials answer these charges. ${ }^{49}$ The Argus claimed that those on the city payroll, especially police officers, could not serve two masters - City Hall and the Ku Klux Klan. In pointing to the ouster of Klansmen from law enforcement positions in Oklahoma City, the newspaper called on the police department, particularly police commissioner Victor Miller, to fire any officer who admitted to being in the Klan. ${ }^{50}$

While it waited for an answer regarding the status of police officers, the Argus also demanded that Mayor Kiel make a statement on the Klan. Though acknowledging that an outright condemnation was not absolutely necessary, the Argus noted that "as Mayor of a City like St. Louis, with its many different nationalities and religious beliefs, we could not but think that Mayor Kiel would have spoken on the subject." ${ }^{51}$ Such a statement was important to the Argus because:

From Maine to California, the Ku-Klux-Klan has for the past six months been the subject of much discussion. Men from the highest in public affairs to the man in the gutter have passed judgment on this organization, which has caused so much agitation and newspaper comment. We

\footnotetext{
${ }^{48}$ Greene, Published in the Interest of Colored People, 44-45.

${ }^{49}$ St. Louis Post-Dispatch, 6 September 1921; St. Louis Argus, 9 September 1921.

${ }^{50}$ St. Louis Argus, 9 September 1921.

${ }^{51}$ St. Louis Argus, 16 September 1921.
} 
have watched with considerable interest, the conduct of public officials toward the Klan, not only in St. Louis, but in other cities in different section of the country. This observation was made necessary by the announced policy of the Klan to "first get public officials" as members. Following this announcement policy, the mayors of many cities and other public officials denounced the Ku-KluxKlan and pledged the assistance of their good offices in suppression such an organization...But to date, we have not heard a word from Mayor Kiel with regard to the activities of the Klan in St. Louis, nor his attitude toward the same...Surely it would be the manly thing for the Mayor, as chief executive of the city, to speak on the subject "Silence gives consent." 52

City officials, especially Mayor Kiel, may have been silent on the Klan issue, but this was not the case for the Argus and its African American readers. As the World expose drew to a close, the local NAACP held a meeting to discuss the Klan as well as recent showings of Birth of a Nation and declared both to be "a menace to peaceful government." Initially issuing a resolution asking the mayor to stop showings of the film, a committee comprised of NAACP members decided to take the matter directly to Kiel. In a short meeting, the committee visited Kiel in his office and addressed concerns they had regarding the film, the Klan, and racial intolerance. Kiel listened to the complaints then dismissed the group without immediate action. In response to Kiel's seemingly lack of concern, the Argus pointed out that the mayor had obviously not changed his opinion of the film since he had previously supported the showing of Birth of a Nation when it first appeared in St. Louis. The Argus juxtaposed this reaction by pointing out how quickly the mayor had acted when Jews protested the anti-Semitic comments of the Dearborn Independent (see Chapter 3). Finally, the Argus called on Victor Miller,

52 St. Louis Argus, 16 September 1921. 
President of the Board of Police Commissioners, to do what Kiel would not do: inform the citizens of St. Louis about where the police department stood on the Klan. ${ }^{53}$

Not satisfied with the delay in the mayor's response to the Argus' inquiry, the Missouri Negro Republican League Club and Central Civic League soon organized a mass meeting at the Tabernacle Baptist Church. A large crowd, estimated at 1500 people, occupied every available space both inside and outside of the church. For those in attendance, including J.E. Mitchell and Alderman Luke E. Hart, there was only one subject on the agenda: the Ku Klux Klan. Many of the speakers criticized Mayor Kiel for his inaction, including Rev. T.J. Moppins who had denounced the Klan in his previous Sunday sermon by claiming that "the wonder that Christian America has such a spirit dominating it at this time, is what give pain to all liberty-loving citizens of the christian [sic] world." ${ }^{, 54}$ In drafting another resolution demanding that the mayor take action and denounce the Klan, it is likely that those at the meeting expected Kiel to continue to ignore and dismiss their request. The mayor, however, was much more receptive to this new resolution and immediately issued an official denouncement of the Klan. ${ }^{55}$

Despite Kiel's statement against the Klan, the Argus continued to push city officials for further action against the hooded order. It called for the mayor to ban all Klan-related activities in the city and for Victor Miller to bring forth an investigation of Klan membership among police officers. The Argus also asked Luke E. Hart, who had

${ }^{53}$ St. Louis Argus, 23 September 1921.

54 St. Louis Argus, 30 September 1921; St. Louis Post-Dispatch, 28 September 1921; St. Louis Globe-Democrat, 28 September 1921.

55 St. Louis Argus, 30 September 1921; St. Louis Post-Dispatch, 28 September 1921; St. Louis Globe-Democrat, 29 September 1921. 
previously worked with the Knights of Columbus to combat anti-Catholicism, to present an anti-Klan resolution to the Board of Aldermen. ${ }^{56}$ On the eve of the Aldermen's meeting, the St. Louis League of Women Voters added its name to the ever growing list of those to condemn the Klan. In a resolution approved by the Executive Committee, the group declared that it "emphatically condemns the Ku Klux Klan and all organized influences that...inflame race and sectional hatred and strife in the American people." ${ }^{257}$ As the Argus had hoped, public pressure over the hooded order forced the Board of Aldermen to take up an anti-Klan resolution at its early October meeting. It was not Luke Hart, however, who was the resolution's sponsor. Instead, Alderman Sylvester Nagle of the $25^{\text {th }}$ Ward introduced the resolution before the Board due to Hart's absence. The resolution stated that "the Board of Aldermen of the City of St. Louis is unalterably opposed to this un-American organization and hereby calls upon the Governor of the State to do all within his power to lawfully suppress the Ku-Klux-Klan within the State of Missouri." ${ }^{258}$ After being read, the resolution was brought to a vote and immediately went down in defeat. Only five alderman, Nagle, William Tamme ( $6^{\text {th }}$ Ward), William Niederlucke ( $3^{\text {rd }}$ Ward), Thomas Watts $\left(17^{\text {th }}\right.$ Ward $)$, and Board President Louis Aloe voted in favor of the resolution. The twenty-three remaining aldermen abstained from voting citing a lack of clear information regarding the Klan's activities. ${ }^{59}$ Responding to

\footnotetext{
${ }^{56}$ St. Louis Argus, 30 September 1921.

${ }^{57}$ St. Louis Post-Dispatch, 6 October 1921; St. Louis Argus, 7 October 1921.

58 St. Louis Argus, 14 October 1921.

${ }^{59}$ St. Louis Post-Dispatch, 8 October 1921; St. Louis Globe-Democrat, 8 October 1921; St. Louis Star, 8 October 1921. St. Louis Argus, 14 October 1921. Those who refused to vote in favor of the antiKlan resolution were Gus A. Baur (14 ${ }^{\text {th }}$ Ward), Alfred Bergmann (18 ${ }^{\text {th }}$ Ward), Ralph H Eilers $\left(26^{\text {th }}\right.$ Ward), John Fett (11 ${ }^{\text {th }}$ Ward), Charles A Groeschel (24 ${ }^{\text {th }}$ Ward), Joseph Heckel $\left(13^{\text {th }}\right.$ Ward), Joseph Hirth $\left(8^{\text {th }}\right.$ Ward), Hermann C. Kralemann (22 ${ }^{\text {nd }}$ Ward), Edward Kuhs ( $1^{\text {st }}$ Ward), Martin D. Lohman ( $9^{\text {th }}$ Ward), George
} 
the resolution's defeat, the Argus lambasted the Board's abstention citing that "[ $\mathrm{t}] \mathrm{he}$ public official who does not know anything about the Klan in this enlightened day, may be properly styled a 'pin-head,' and should be somewhere on a farm or an institution for the feeble-minded." 60 The Argus then warned its readers to "remember [that] the men who voted to defeat the resolution are among those whom you voted for along with the 'Straight Republican Ticket.'...they are those who have betrayed your trust and confidence."

The Board of Aldermen took up the anti-Klan resolution again in mid-October, though rumors swirled that local Klansmen tried to influence a no-vote once more. ${ }^{62}$ At the second meeting, Edward Kuhs and Adam Reis, who had abstained during the first vote, presented the resolution. On its second vote, the anti-Klan resolution tallied fourteen "yes" votes. But, it was defeated once more after falling one vote short of a majority. Noticeably absent from the second vote was Aldermen William Tamme from the predominantly African American $6^{\text {th }}$ Ward who had been one of the few aldermen to support the anti-Klan resolution on its first vote. No reason was given for his absence. ${ }^{63}$

While St. Louisans may have failed in their efforts to have the Board of Aldermen denounce the Klan, all was not lost for anti-Klan supporters. Opposition sentiment

Meisinger (10 $10^{\text {th }}$ Ward), Charles A. Neumann (12 ${ }^{\text {th }}$ Ward), August H. Niederluecke (19 $9^{\text {th }}$ Ward), William Otto ( $4^{\text {th }}$ Ward), Adam Reis (16 ${ }^{\text {th }}$ Ward), Edward Scholl ( $2^{\text {nd }}$ Ward), Wilber C. Schwartz (12 ${ }^{\text {th }}$ Ward), Clinton E. Udell ( $23^{\text {rd }}$ Ward), William J. Studt $\left(21^{\text {st }}\right.$ Ward), Harry Uhlemeyer $\left(15^{\text {th }}\right.$ Ward $)$, Henry Wander $\left(7^{\text {th }}\right.$ Ward), Edward Wiehe ( $5^{\text {th }}$ Ward), Samuel L. Wimer $\left(27^{\text {th }}\right.$ Ward).

${ }^{60}$ St. Louis Argus, 14 October 1921.

${ }^{61}$ St. Louis Argus, 14 October 1921.

${ }^{62}$ St. Louis Star, 8 October 1921.

${ }^{63}$ St. Louis Post-Dispatch, 15 October 1921; St. Louis Globe-Democrat, 15 October 1921; St. Louis Star, 15 October 1921. 
among the local press, combined with public comments by Mayor Kiel, made the activities of the Klan a quickly developing state issue. Not surprisingly, and much to the delight of anti-Klan advocates, a major denouncement of Missouri’s hooded order soon came from the State Capitol in Jefferson City. Arthur Hyde, the recently elected governor of the state, issued two condemnations of the Invisible Empire. His comments not only strengthened the claims of opponents of the Klan, but also set the stage for bigger battles with the group in the coming years. Hyde first denounced the Klan as an unnecessary law enforcement agent at an August speech in Joplin. ${ }^{64}$ He followed these comments up with a well-publicized address in front of 500 members of the Grand Lodge of Missouri Ancient Free and Accepted Masons. With allegations suggesting a close link between the organization and the Klan, the Masons acted quickly to separate themselves from activities of the order. ${ }^{65}$ Soon after, Hyde received national recognition for his stance on the Invisible Empire from prominent former Klansman C. Anderson Wright as well as Herbert Bayard Swope of the New York World. ${ }^{66}$

Though Governor Hyde's denouncements carried significant weight, it is obvious that they came out in the midst of political pressure in regards to the Klan issue. As early as April 1921, Hyde had received letters from concerned Missourians requesting action

${ }^{64}$ St. Louis Post-Dispatch, 25 August 1921; Church Progress, 1 September 1921.

65 St. Louis Post-Dispatch, 9 September 1921, 20 September 1921; Joplin Globe, 21 September 1921, 23 September 1921, 23 October 1921; St. Louis Argus, 23 September 1921.

${ }^{66}$ Herbert Bayard Swope to Arthur Hyde, Western Union Telegram, 8 September 1921, Folder 365, Arthur Mastick Hyde Papers, State Historical Society of Missouri, Columbia, Missouri (Hereafter the Arthur Mastick Hyde Papers will be cited as AMH and the State Historical Society of Missouri will be cited as SHS-MO); C. Anderson Wright to Arthur Hyde, 23 September 1921, Folder 365, AMH, SHS-MO; C. Anderson Wright to Arthur Hyde, 28 September 1921, Folder 365, AMH, SHS-MO; Arthur Hyde to C. Anderson Wright, 26 September 1921, Folder 365, AMH, SHS-MO; Arthur Hyde to C. Anderson Wright, 4 October 1921, Folder 365, AMH, SHS-MO. 
against the Klan. In noting the arrival of the Klan in Springfield, a local resident asked Hyde if he would "permit this poison to flow unchecked."67 The Inter-Racial Committee of the Citizens' League of Kansas City and Jackson County, advised Hyde, along with Kansas City's Mayor and Chief of Police, to discourage the formation of the Klan in Missouri. ${ }^{68}$ The Negro Women's National Republican League reminded Hyde that the "Ku Klux Klan is unamerican [sic] and lawless in spirit, anti-Catholic, anti-Jewish as well as anti-Negro and should be excluded from all American Cities desiring order and amicable relations between the races." 69

Just as Hyde faced political pressure regarding the Klan, so too did Missouri's congressional members. Since late summer of 1921, politicians, newspaper editors, and private citizens had called upon the federal government to stifle the growth of the Klan much like it had done with the Enforcement Acts and the Reconstruction Klan. The Church Progress, which had applauded Governor Arthur Hyde's condemnation of the Klan, argued that such denouncements only went so far and would only be effective through a federal investigation. ${ }^{70}$ The Jewish Voice proclaimed that "the time has come when Fordism, Ku Klux Klanism and every individual or organization that stands for hate and prejudice must be eliminated from American life, otherwise we shall never have AMERICANISM and all that it stands for in this country.",71

${ }^{67}$ T.S. Hardy to Arthur Hyde, 26 April 1921, Folder 365, AMH, SHS-MO.

68 Nat Spencer to Arthur Hyde, 30 July 1921, Folder 365, AMH, SHS-MO; Kansas City Journal, 30 July 1921; Kansas City Times, 30 July 1921.

${ }^{69}$ Monen L. Gray to Arthur Hyde, 23 August 1921, Folder 365, AMH, SHS-MO.

${ }^{70}$ Church Progress, 1 September 1921.

${ }^{71}$ Jewish Voice, 13 October 1921. 
With momentum building for federal action, St. Louis Congressman Leonidas Dyer issued a resolution demanding that the government investigate the Klan. ${ }^{72}$ Dyer, who was the main sponsor of the Dyer Anti-Lynching Bill, one of the most hotly debated pieces of legislation at the time, had assured his constituents that "everything possible should be done to suppress and destroy the Ku Klux Klan."73 In addition to Dyer's comments on the Klan, the NAACP sent out a questionnaire to members of Congress regarding their stance on the KKK in anticipation of a federal hearing. ${ }^{74}$ Among those polled were Missouri Republican Representatives Roscoe C. Patterson, T.W. Hukriede, and I.V. McPherson. In a letter to James Weldon Johnson, Patterson declared that he was "unreservedly opposed to any secret organization that finds it necessary for its members to hide their faces and forms behind a mask." ${ }^{75}$ Hukriede also responded to the inquiry by assuring Johnson that "I consider...un-American any organization which is founded on race hatred or religious hatred... and as the Ku Klux Klan falls in this category, I am unalterably opposed to this organization."76 McPherson informed the NAACP that organizations that "excite riots and usurp the power of government deserve the condemnation of all law abiding citizens." 77

\footnotetext{
72 St. Louis Post-Dispatch, 18 September 1921, 2 October 1921

${ }^{73}$ St. Louis Argus, 7 October 1921.

74 “Colored Advancement Society Polls Congress on Ku Klux Klan," Press Release, 13 October 1921, Folder 13, Box 1: C312, NAACP, LOC.

${ }^{75}$ Roscoe C. Patterson to James Weldon Johnson, 8 October 1921, Folder 14, Box 1: C312, NAACP, LOC.

${ }^{76}$ T.W. Hukriede to James Weldon Johnson, 7 October 1921, Folder 14, Box 1: C312, NAACP, LOC.

${ }^{77}$ I.V. McPherson to N.A.A.C.P., 12 October 1921, Folder 14, Box 1: C312, NAACP, LOC.
} 
Owing to outside pressure, Congress finally decided to investigate the Klan in October 1921. Led by the House Rules Committee, the series of public hearings lasted a week and included testimony ranging from first-hand accounts of alleged Klan violence to comments on the Invisible Empire by former and current Klansmen. Among those testifying on the first day of the hearings were Rowland Thomas, an investigator for the New York World expose; C. Anderson Wright, a former Klansmen from New York; William J. Burns, Director of the Department of Justice's Bureau of Investigation; and Congressmen from New York, Massachusetts, and Missouri. ${ }^{78}$ Leonidas Dyer appeared before the Committee on Rules to explain that "my attention to this matter has been called by the people whom I have the honor to represent in the Congress, the people of the city of St. Louis, and for that reason I have been led to ask for an investigation...[o]f course, what affects the people of my city largely affects those of the entire country.",79 Dyer informed the committee that he wanted a federal investigation of the activities undertaken by the Klan outside of its meeting halls. He specified that he did not object to the Klan's policy of denying membership to certain groups, but, while reading letters sent to him regarding Klan violence to the committee, he made clear that the organization was performing extralegal duties in some local communities. ${ }^{80}$

On the second day of the hearings, the Imperial Wizard arrived to defend his Invisible Empire. Fighting a lengthy spell of tonsillitis and bronchitis, William Simmons underwent a barrage of questions from the committee in the hopes of clearing the Klan's

\footnotetext{
${ }^{78}$ House Committee on Rules, The Ku-Klux Klan: Hearing before the Committee on Rules, $67^{\text {th }}$ Cong., $1^{\text {st }}$ sess., $1921,3-48$.

${ }^{79}$ House Committee, The Ku-Klux Klan, 6.

${ }^{80}$ House Committee, The Ku-Klux Klan, 6-8.
} 
name. During the course of his testimony, Simmons claimed that rival groups were actually performing the vigilantism that was being attached to the Klan. He even announced that the Klan would disband if such charges of violence turned out to be true. Instead, he repeatedly argued that the Klan held much loftier ambitions and goals. ${ }^{81}$ The back and forth between the Imperial Wizard and the committee reached a climax on the hearing's third day when Simmons declared:

I want to say to my persecutors and the persecutors of this organization in all honesty and sincerity, no matter to what creed or race you may belong in your persecutions, through the medium of the press or otherwise, that you do not know what you are doing. You are ignorant of the principles as were those who were ignorant of the character and work of the Christ. I can not better express myself than by saying to you who are persecutors of the klan [sic] and myself, "Father, forgive you, for you know not what you do," and "Father, forgive them, for they know not what they do." 82

After uttering these words, Simmons collapsed and the committee adjourned for the day. ${ }^{83}$ The lack of sufficient evidence, combined with Simmons' performance in front of the congressional committee, produced little support for a further investigation or wide sweeping anti-Klan legislation. Instead, attempts to discredit the Klan only made it stronger. As has been noted by several historians of the 1920s Klan, the publicity given to the Klan during the hearings brought even more recruits into the Invisible Empire. ${ }^{84}$

\footnotetext{
${ }^{81}$ House Committee, The Ku-Klux Klan, 67-184; Lay, Hooded Knights on the Niagara, 4; William Jenkins, Steel Valley Klan, 6.

${ }^{82}$ House Committee, The Ku-Klux Klan, 138.

${ }^{83}$ House Committee, The Ku-Klux Klan, 139.

${ }^{84}$ Lay, Hooded Knights on the Niagara, 4; William Jenkins, Steel Valley Klan, 6. For local coverage of the Congressional investigation see St. Louis Post-Dispatch, 11 October 1921, 12 October 1921, 13 October 1921, 14 October 1921, 15 October 1921, 16 October 1921, 17 October 1921, 18 October 1921; St. Louis Globe Democrat, 13 October 1921, 14 October 1921; Church Progress, 20 October 1921, 27 October 1921; Joplin Globe, 12 October 1921, 13 October 1921, 14 October 1921, 15 October 1921, 18
} 
Despite the heat from the congressional hearings and the anti-Klan press, hooded recruitment continued in Missouri. In St. Joseph, Kleagle E.L. Coleman quietly recruited for the Klan, but so far, his efforts to establish a chapter in the city had failed. He had garnered sixteen members by the end of September when his recruiting materials fell into the hands of the Chief of Police, Clay McDonald. Upon learning that Klan planned to hold a recruitment meeting at the Malcom McDonald Post Hall, the Chief of Police contacted the owners of the hall to tell them to cancel the meeting and refund the money to the group. McDonald then placed a squad of men outside the building to turn away those planning to attend the meeting. As the attendees arrived at the meeting and began to mingle around outside in confusion over the cancellation, an unknown man informed them that the event had been moved to the St. Francis Hotel. But, to their surprise, Chief McDonald had beaten them to the hotel and, again, shut down the meeting. Soon after, E.L. Coleman left St. Joseph. ${ }^{85}$

In the aftermath of Chief McDonald's actions, public sentiment seemed to be in support of preventing the Klan from holding meetings in the city. The Catholic Tribune commended McDonald for his attack upon the Klan and quoted the proprietor of the St. Francis Hotel as saying that he "would not have rented the place for any Ku Klux Klan

October 1921; Joplin News-Herald, 11 October 1921, 12 October 1921, 13 October 1921, 17 October 1921; St. Joseph News-Press, 12 October 1921, 14 October 1921; St. Joseph Gazette, 12 October 1921,13 October 1921, 14 October 1921, 15 October 1921, 18 October 1921; St. Joseph Catholic Tribune, 22 October 1921, 29 October 1921, 5 November 1921; Hannibal Courier-Post, 10 October 1921, 11 October 1921, 12 October 1921, 13 October 1921, 17 October 1921; Jefferson City Daily Capital News, 12 October 1921, 13 October 1921, 14 October 1921; Columbia Daily Tribune, 11 October 1921, 14 October 1921; Kansas City Journal, 12 October 1921, 13 October 1921, 14 October 1921, 15 October 1921, 18 October 1921; Kansas City Star, 11 October 1921, 12 October 1921, 13 October 1921, 14 October 1921.

${ }^{85}$ St. Joseph News-Press, 29 September 1921; St. Joseph Gazette, 29 September 1921; St. Joseph Observer, 1 October 1921; St. Joseph Catholic Tribune, 1 October 1921. 
meeting [because] I am against this sort of thing and always will be." ${ }^{86}$ The St. Joseph News-Press declared that there was "ample room for organizations devoted to 100 per cent Americanism...but a 100 per cent American needs no ghoulish uniform, no horrific oaths, no appeals to religious or racial prejudice to keep his patriotism militant." 87 The Observer noted that some local residents had received threatening letters, allegedly written by Klansmen, warning them to desist from their work with the city park propositions. ${ }^{88}$ Though it acknowledged that members of the KKK might not have written the letters and that many prominent men were allegedly in the crowd before Chief McDonald cancelled the earlier Klan event, the Observer also reserved space in its editorial section to lampoon the Invisible Empire because:

...evidently there are people in plenty who think that it is worth the money to become Terrors and Giants and Cyclopes. Your Grand Goblin may be the village barber. The Grand Titan may be the local undertaker trying to swell himself out to fit his title and his official costume. A Giant may be a human peewee striving to drown his inferiority complex in vain imaginings born of his mighty title. If it wasn't that this business is inflaming hateful and malignant passions which civilized man ought to kill instead of encouraging, the whole affair would be the funniest thing of $1921 .{ }^{89}$

While the St. Joseph press issued widespread denouncements of the Invisible Empire, the Gazette took it one step further and reached out to twenty-five prominent city leaders to inquire about their stance on the Klan. As its front page attested, the Gazette

\footnotetext{
${ }^{86}$ St. Joseph Catholic Tribune, 1 October 1921.

87 St. Joseph News-Press, 30 September 1921.

88 St. Joseph Observer, 1 October 1921.

${ }^{89}$ St. Joseph Observer, 8 October 1921.
} 
found that the consensus of those asked found the Klan to be Un-American. Most

respondents spoke out in opposition to lawlessness and vigilantism more so than just the

Klan. Some of those polled, however, took direct aim at the hooded order. ${ }^{90}$ Chief of

Police McDonald, who had allegedly received threats from the Klan after he shut down

meetings, restated his opposition. ${ }^{91}$ He was joined by Buchanan County Sheriff Bill

Kucker who also denounced the Klan. St. Joseph Mayor Elliot Marshall told the Gazette that he was "so damnably strong against the Ku Klux Klan...that I will do all in my

power as mayor and personally to stop it." 92

Though the Klan faced an uphill battle in St. Joseph, Joplin's Ozark Klan No. 3 had grown steadily, yet quietly, throughout 1921. By October, rumors circulated that local membership numbered close to one thousand men. But like St. Joseph, the Joplin Klan faced opposition from the Chief of Police. Joe H. Myers' concerns about the Klan originated from an increase in KKK activity in the city. In mid-October, "a shroud of secrecy and a hush of silence, except for the occasional outbreak of handclapping,

${ }^{90}$ St. Joseph Gazette, 2 October 1921. Those polled by the Gazette included Clay McDonald (St. Joseph Chief of Police), C.M. Chilton (pastor of First Christian Church), Webb Siemens (Commander of the Malcolm McDonald Post, American Legion), Harry Ramm (Potentate of Molia Temple Shrine), James E. Cox (chairman of Club Presidents' Round Table and president of Commerce Club), Rabbi Garry August (Temple Adath Joseph), Rev. James P. Brady (Roman Catholic Diocese of St. Joseph), T.B. Allen (local judge), A.B. Duncan (Probate Judge), Perry Burbaker (Buchanan County Prosecuting Attorney), Allen May (Municipal Court Judge), Elliott Marshall (St. Joseph Mayor), Bill Kucker (Buchanan County Sheriff), Mrs. Arthur L. Loving (member of the Pershing Chapter of the Service Star Legion), Mrs. Elliott Spalding (president of the Federation of Women's Clubs), Miss Anne Reily Nesom (general secretary of the Y.W.C.A.), P.E. Parrot (president of the Board of Directors of the Y.M.C.A.), R.E. Squires (general secretary of the Y.M.C.A.), J.W. Holiman (city councilman), Ralph B. Innis (Legionnaire), Claude Madison (local Mason), Barney E. Reilly (Grand Knight, Knights of Columbus), Oscar E. Fox (Commander of Custer Post No. 7, G.A.R.), W.H. Utz (local judge), L.A. Vories (local judge), and J.A. Milbourne (Commander of Jack Schneider Post, Veterans of Foreign Wars).

${ }^{91}$ St. Joseph Gazette, 1 October 1921, 2 October 1921.

92 St. Joseph Gazette, 2 October 1921. 
reigned in the big auditorium" as the Klan held a rally at Schifferdecker Park. Among the close to 1500 in the audience were J.M. Lane (Commissioner of Public Property and Utilities), Dr. M.B. Harutum (Commissioner of Health and Sanitation), and Harry Wondell (Fire Chief). In order to gain admittance, attendees had to sign a card with a series of questions on it. This was not an official application for membership, but it was a contact form for recruiting purposes that bound the signer to silence regarding what occurred at the rally. After Chief Myers refused to sign the card, he was denied entry into the event. ${ }^{93}$

When pressed by the Joplin Globe regarding his appearance at the rally, Chief Myers denounced the Klan and its activities. He added that he did not plan on investigating the Klan in Joplin because the federal government was currently conducting a formal hearing on the KKK, but he would "make it my business to find out who they are and what they are about, in any such event, and will prevent their works if I find they are unlawful." ${ }^{94}$ Despite Myers' attack on the Klan, others in the community initially found little wrong with the Invisible Empire. Mayor J.F. Osbourne announced that city officials would not interfere with organizations that as long as they were "lawful." J.M. Lane, Harry Wondell, and city attorney Ray Bond all told the press that they got a favorable impression of the Klan from the rally. ${ }^{95}$

In the wake of Myers' denouncement of the Klan, G.A. Glasscock, who was one of the speakers at the Schifferdecker Park rally, issued a statement to the Globe regarding

\footnotetext{
93 Joplin Globe, 18 October 1921; Joplin News-Herald, 17 October 1921, 18 October 1921.

94 Joplin Globe, 18 October 1921; Columbia Missourian, 18 October 1921.

95 Joplin News-Herald, 18 October 1921.
} 
to the matter. Glasscock specified that Myers was turned away because he refused to sign the card and thus respect the secret information discussed at the meeting. Glasscock accused Myers of basing his ideas about the hooded order on literature distributed by anti-Klan advocates who criticized the Klan as "[u]n-American, undemocratic and a damnable anachronism."96 To counter claims made by local anti-Klan individuals, Ozark Klan No. 3 embarked on a philanthropy drive for the "benefit of the poor" and declared to those who suggested that the hooded order was violent that "We, as Klansmen, do not condone murder or any other criminal act...We believe we are better citizens for being Klansmen."97

As the Klan continued to spread from Oklahoma to Kansas and into Missouri border communities like St. Joseph and Joplin, the Kansas City Call felt a great unease with the arrival of the hooded order in the "land of John Brown."98 There was reason for the newspaper to be concerned. With its movement out of the American South, the Klan had made its way from Texas to Oklahoma and now to Missouri and Kansas. At the confluence of the Kansas and Missouri rivers, marking the borders of their respective states stood Kansas City. With the Klan spreading into Kansas, and using western Missouri as an avenue into that state, Kansas City stood as a major acquisition for the Invisible Empire. The "kluxing" of Kansas City, however, would not be easy. When propositioned about membership, the local Chief of Police informed an alleged Klansman

96 Joplin Globe, 19 October 1921; Joplin News-Herald, 17 October 1921, 18 October 1921.

97 Joplin Globe, 20 December 1921, 25 December 1921. For articles that focus on alleged Klan violence in the South see Joplin Globe, 23 July 1921, 2 October 1921, 6 October 1921, 2 November 1921, 6 November 1921, 24 November 1921, 4 December 1921.

${ }^{98}$ Kansas City Call, 29 April 1922. 
that the city did not need the Invisible Empire. ${ }^{99}$ Added to this, after it was rumored that Grand Goblin Frank Crippen was personally recruiting in the region, the Call assured its readers that "Kansas may not always think right, but it always thinks out loud and in plain sight where all men can see...the supremest [sic] folly the Klan has yet committed is to attempt to plant its exotic, miasmic growth in the sunny vales and plains of Kansas."100 Yet, the Call continued to warn all that would listen that "Lucifer has entered the holy of holies." 101

The Call may have seen a folly in the spread of the Invisible Empire into Kansas, but Harry H. Mayer, rabbi of B'nai Jehudah Temple and contributing editor of the Kansas City Jewish Chronicle, viewed it differently. In the aftermath of World War I, many in the Jewish community felt the full brunt of a wave of anti-Semitism and antiforeignism that swept the United States. ${ }^{102}$ From its beginning in 1920, the Jewish Chronicle served as an important spokesperson for "Jews in the non-Jewish community" by promoting local interests and offering news stories on the experiences of Jews around the world. ${ }^{103}$ It was influenced by Mayer in its early years and asserted that "every movement, every

${ }^{99}$ Kansas City Journal, 24 July 1921.

${ }^{100}$ Kansas City Star, 12 October 1921; Kansas City Call, 29 April 1922.

${ }^{101}$ Kansas City Call, 29 April 1922.

102 For general resources on the Ku Klux Klan and Anti-Semitism in the United States in the early $20^{\text {th }}$ Century see Jonathan D. Sarna, American Judaism: A History (New Haven: Yale University Press, 2004), 214-223; Jacob M. Sable, Some American Jewish Organizational Efforts to Combat Anti-Semitism, 1906-30 (Ph.D. Diss., Yeshiva University, 1964), 258-259; Leonard Dinnerstein, Antisemitism in America (Oxford: Oxford University Press, 1994), 78-104; David A, Gerber, ed., Anti-Semitism in American History (Urbana: University of Illinois Press, 1986), 22-33; Lynn Dumenil, The Modern Temper: American Culture and Society in the 1920s (New York: Hill \& Wang, 1995), 214-217, 235-249.

103 Judith M. Firestone, "Jewish Journalism in Kansas City," in Mid-America's Promise: A Profile of Kansas City Jewry, ed. Joseph P. Schultz (Kansas City: The Jewish Community Foundation of Greater Kansas City, 1982), 185-198. 
enterprise, every undertaking which will help Jews" would get support from the newspaper, while "every movement that is antagonistic to the good name of the Jew, every statement that is defamatory to him, will be vigorously opposed." 104

For Jews in Kansas City, it seemed that their neighbors had contracted a disease which Mayer labeled as "Ku Klux Klanitis." It was an "insidious poison” and a "pernicious germ of class hatred and class tyranny" whose chief symptoms included "defying constituted authority, clashing with state and city officials, invading homes, and violating there the right of the individual to regard his home as his castle." This "contagion" which had "fastened itself to us with alarming results" was found primarily in Texas and California. ${ }^{105}$ Recently, however, it had "infected" the occupants of the Armory Hall in Kansas City, Kansas. ${ }^{106}$ This Kansas Klan, identified as Wyandotte Klan No. 5, had solicited members and attempted to curry favor with local citizens through a recent series of church donations. ${ }^{107}$

Despite the Klan's claims of tolerance, Harry Burton, the mayor of Kansas City, Kansas, was not pleased to see the hooded order, which he referred to as "a mistake... [that] should have no place among us," in his town. Burton issued a public statement denouncing the Klan and ordered all city employees affiliated with it to resign their positions. ${ }^{108}$ In his public comments, Burton referred to the Klan as "un-American"

${ }^{104}$ Firestone, "Jewish Journalism in Kansas City," 186.

${ }^{105}$ Kansas City Jewish Chronicle, 12 May 1922.

106 Kansas City Catholic Register, 11 May 1922.

107 Kansas City Catholic Register, 27 April 1922, 22 June 1922; Rush, The Ku Klux Klan in Kansas City during the Twenties, 98-102.

108 Kansas City Catholic Register, 27 April 1922; St. Louis Argus, 5 May 1922; The Kansan, n.d., Ku Klux Klan - April, 1922, Folder 17, Box C-313, NAACP, LOC. 
while touting the positive accomplishments of groups like the NAACP. ${ }^{109}$ The mayor stood his ground on the issue, and even initially agreed to debate a Klan lecturer at the London Heights Methodist Church in 1922. ${ }^{110}$ Unfortunately, Burton's anti-Klan stance could not stem the tide of Klan support in Kansas City. ${ }^{111}$ More and more people, it seemed, were catching "Ku Klux Klanitis," and Burton could not provide the proper "antidote." Yet, despite the growing Klan fever and fervor in Kansas City, the Jewish Chronicle felt confident that the "American people will certainly not tamely submit" to the Invisible Empire. ${ }^{112}$

While newspapers like the Call and Jewish Chronicle may have acknowledged the necessity of cooperation in fighting the Klan, they also questioned who should take the lead in challenging the Invisible Empire. For its editor, C.A. Franklin, there were valid reasons why the Call should challenge the Klan. Like the Mitchell brothers of the Argus, C.A. Franklin was also a southern transplant who found himself in Missouri. Born in Texas in 1880, Franklin's family had a long history in the newspaper business. After moving to Omaha, Nebraska, in 1887, his father operated the local Enterprise. The family stayed in Omaha for a decade, and C.A. enrolled for two years at the nearby University of Nebraska, but his father's failing health soon forced them to move to

\footnotetext{
${ }^{109}$ Kansas City Call, 13 May 1922, 20 May 1922.

${ }^{110}$ Kansas City Catholic Register, 11 May 1922; Shreveport Journal, 7 May 1922, Ku Klux Klan May, 1922, Folder 18, Box C-313, NAACP, LOC; Rush, The Ku Klux Klan in Kansas City during the Twenties, 90-91.

${ }^{111}$ For information on the Ku Klux Klan in Kansas City, Kansas see Timothy Rives, "The Second Ku Klux Klan In Kansas City: Rise And Fall Of A White Nationalist Movement," The Kansas City Public Library, 15 March 2018, http://pendergastkc.org/article/second-ku-klux-klan-kansas-city-rise-and-fall-whitenationalist-movement; Barbara J. Rush, The Ku Klux Klan in Kansas City during the Twenties (Master's Thesis, Marquette University, 1970).

112 Kansas City Jewish Chronicle, 12 May 1922.
} 
Denver. Out west, C.A. worked with his father on a newspaper called the Star. Upon his father's death, he took over as publisher and editor. Following several years spent in Denver, C.A. Franklin moved to Kansas City in $1913 .^{113}$

Despite moving to Kansas City with the hope of improving his newspaper prospects, C.A. Franklin did not publish his first issue of the Call until 1919. However, once he began regular publication, the Call took off as the preferred African American newspaper of the city. In addition to printing attention grabbing headlines to draw in prospective readers, the Call also devoted extensive space in its pages to stories on African American achievements. ${ }^{114}$ Critics, however, sometimes accused the newspaper of avoiding controversial subjects like discrimination and segregation in its pages. Historian Thomas Wilson acknowledges this preference for positive stories in the newspaper, but also notes that Franklin was a proponent of civil rights activism. ${ }^{115}$ When it came to civil rights, Franklin, like J.E. Mitchell of the Argus, was an ardent supporter of Booker T. Washington. He printed information related to DuBois' NAACP and Marcus Garvey's Universal Negro Improvement Association, but he was not an open supporter of either organization. ${ }^{116}$ As a Republican, Franklin was also quite critical of Kansas City’s Democratic political machines led by Joseph Shannon and Tom

113 Thomas D. Wilson, "Chester A. Franklin and Harry S. Truman: An African-American Conservative and the 'Conversion' of the Future President," Missouri Historical Review 88, no. 1 (October 1993), 49-50.

\footnotetext{
${ }^{114}$ Wilson, “Chester A. Franklin and Harry S. Truman," 50-51.

${ }^{115}$ Wilson, “Chester A. Franklin and Harry S. Truman," 51.

${ }^{116}$ Wilson, "Chester A. Franklin and Harry S. Truman," 50, 52, 56.
} 
Pendergast. His support for the Republican Party waned by the end of the 1920s, but for a majority of the decade he was solidly in the Republican camp. ${ }^{117}$

Perhaps one of the most important decisions made by Franklin during his time in charge of the Call was to hire a young editor from Minnesota named Roy Wilkins.

Originally from St. Louis, Wilkins moved to St. Paul, Minnesota following the death of his mother. After graduating from the University of Minnesota, Wilkins became involved in the St. Paul chapter of the NAACP, and, as an active member, went to the organization's annual convention in Kansas City in 1923. It was while in the city for the convention that Wilkins met Franklin. On the lookout for a new editor, Franklin offered Wilkins a chance to cover the convention for the Call. The one-time appointment soon turned into a job, and Wilkins became the newspaper's city editor. ${ }^{118}$ In his new post, Wilkins soon filled the pages of the Call with critiques of Kansas City society, including residential segregation, home bombings, local politics, state funding for predominantly African American institutions, and activities of the Klan. ${ }^{119}$ Later in his life, Wilkins referred to Kansas City as a "Jim Crow town that nearly ate my heart out as the years went by." 120

117 Wilson, “Chester A. Franklin and Harry S. Truman,” 50, 53-56.

118 Wilson, "Chester A. Franklin and Harry S. Truman," 57; Roy Wilkins, Standing Fast: The Autobiography of Roy Wilkins (New York: The Viking Press, 1982), 54-56; Yvonne Ryan, Roy Wilkins: The Quiet Revolutionary and the NAACP (Lexington: University of Kentucky Press, 2014), 1-12.

${ }^{119}$ Wilkins, Standing Fast, 56-110; Schirmer, A City Divided, 115, 128-129; George A. McElroy, Roy Wilkins as a Journalist (MA Thesis, University of Missouri, 1970), 21-42.

${ }^{120}$ Wilkins, Standing Fast, 60. 
Both before and after Wilkins' arrival, the Call monitored the Klan nationwide. ${ }^{121}$ In addition to warning about the group's kluxing in the "land of John Brown," the Call also denounced the Klan's attempts to sway local politics and public opinion through philanthropy and intimidation. ${ }^{122}$ The newspaper was particularly disturbed after the Klan sent letters and donations to a collection of African American churches in Kansas City calling upon the congregations to stand "shoulder to shoulder with your white brethren" against "foreign religious political domination." 123 In appealing to a shared Protestantism, Wyandotte Klan \#5 sought to downplay the notion that its organization was racially intolerant by suggesting that "[w]e have no quarrel with the colored man [because] he is American and as such has the support of American Citizens and we are ever ready to assist him in his lawful pursuit of happiness."124 Yet, though it kept a close eye on hooded activity in and around Kansas City, the Call confessed that there were much more pressing issues in the African American community than the Klan. Perhaps, the Call argued, Catholics or Jews could defeat the Klan. ${ }^{125}$

The Jewish Chronicle did not share the idea that Catholics or Jews should shoulder the burden of fighting the Klan. Citing comments by the former United States

${ }^{121}$ Kansas City Call, 25 March 1922, 29 April 1922, 13 May 1922; 10 June 1922, 17 June 1922; 8 July 1922, 15 July 1922, 13 October 1922, 27 October 1922, 3 November 1922, 10 November 1922, 15 December 1922, 26 January 1923, 1 June 1923, 25 July 1924, 1 August 1924, 3 October 1924, 17 October 1924, 31 October 1924, 16 October 1925, 2 July 1926, 13 August 1926, 24 September 1926, 25 February 1927, 24 June 1927, 17 February 1928.

122 Kansas City Call, 29 April 1922, 13 May 1922, 10 June 1922, 17 Jun 1922, 8 July 1922, 15 July 1922.

\footnotetext{
${ }^{123}$ Kansas City Call, 10 June 1922, 17 June 1922.

${ }^{124}$ Kansas City Call, 10 June 1922.

${ }^{125}$ Kansas City Call, 26 January 1923.
} 
Ambassador to Germany, James W. Gerard, the Jewish Chronicle posited that Jews and Catholics should abstain from fighting the Klan in favor of "[r] ight-minded Protestants [who] would exterminate the Klan in a short time...[and] slay the dragon.” Agreeing with Gerard, Harry H. Mayer assured the readers of the Jewish Chronicle that "we can well afford to wait until decent Protestants are aroused by the seriousness of the vicious propaganda and the lawlessness which the 'Invisible Empire' has incited." 126 By late 1924, a survey of prominent Jewish leaders conducted by the Jewish Telegraphic Agency found that most favored a campaign against the Klan organized and carried out by Protestant denominations. ${ }^{127}$

Though local Jews may have been somewhat eager to let Protestants lead the charge against the Invisible Empire, some in the Catholic community, particularly the Kansas City Catholic Register, were not ready to give up the fight. With rumors swirling about Klan activity along the Missouri-Kansas border, the Register assured its readers that "the Catholic people of Kansas City, while they are ready to fight the Klan at every step, are not laying awake nights worrying about it." ${ }^{128}$ Yet despite strong confidence in local Catholics, the Register still launched an investigative campaign to "out" those affiliated with the Klan. In the latter half of 1922, with extra intensity around Election Day, the Register turned its newspaper over to non-stop Klan coverage. From national stories to local Klan "sidelights," the Register made sure Kansas City residents knew the

\footnotetext{
${ }^{126}$ Kansas City Jewish Chronicle, 15 December 1922.

${ }^{127}$ Kansas City Jewish Chronicle, 22 August 1924.

${ }^{128}$ Kansas City Catholic Register, 29 June 1922.
} 
Klan's every move and who hid under the mask. ${ }^{129}$ In splashing the names of suspected Klansmen on the front page, the Register always offered space in its next edition for explanations and rebuttals from those caught in unfortunate situations. ${ }^{130}$

By September 1922, the Register took its expose journalism one step further. In addition to publishing the identities of those attending, and in some cases parked outside of Klan events, as well as recycling some of the original New York World Klan articles from 1921, the newspaper found itself in possession of a unique prize: a directory distributed by the local Klan of affiliated and sympathetic businesses. ${ }^{131}$ Wasting little time, the Register reprinted the entire directory in its September $28^{\text {th }}$ edition. From this list, Kansas City Catholics found out whether their barber, dentist, grocer, or insurance agent expressed sympathy with the Invisible Empire. ${ }^{132}$ Despite accusations of launching a boycott campaign against Klan-affiliated businesses, a charge that Justin Casey, managing editor of the Register, flatly denied; the newspaper continued to publish the names of those closely aligned with the Invisible Empire. ${ }^{133}$ This ever-growing list included local ministers who had accepted donations from the Klan as well as

${ }^{129}$ Kansas City Catholic Register, 11 May 1922, 18 May 1922, 25 May 1922, 22 June 1922, 29 June 1922, 27 July 1922, 14 September 1922, 21 September 1922, 28 September 1922, 5 October 1922, 12 October 1922, 19 October 1922, 26 October 1922, 4 November 1922, 11 November 1922, 16 November 1922.

${ }^{130}$ Kansas City Catholic Register, 18 May 1922, 25 May 1922.

${ }^{131}$ For examples of New York World articles republished in the Kansas City Catholic Register see 14 September 1922, 21 September 1922, and 28 September 1922.

132 Kansas City Catholic Register, 28 September 1922.

${ }^{133}$ Kansas City Journal, 12 October 1922. 
participants in an alleged Klan-backed boycott in neighboring Lee's Summit. ${ }^{134}$ If anyone had a problem with their name appearing in the Register under such circumstances, the newspaper advised that "the courts are the places for him." 135

After nearly two years of un-masking the Klan in public and in print, anti-Klan activists and the press gained a major endorsement of their actions from one of Missouri's most prominent native sons. John J. "Black Jack” Pershing was the quintessential American boy turned national hero. Having been in the United States military since he left his Laclede, Missouri, farm in the 1880s, Pershing served as the Commander of the American Expeditionary Force during World War I. He returned from the Western Front a decorated war hero and potential presidential candidate. He passed on elected office, but nevertheless remained a vocal figure in American life. ${ }^{136}$ During a series of speeches with the Association of Commerce and American Horse Show Association in 1922, Pershing turned his attention to the hooded order. ${ }^{137}$ Noting the upsurge in radicalism after the war, the general warned those assembled about the dangers residing within the United States. "There is little difference between the malign influence of the radical who bores from within and the malign influence of the Ku Klux Klan," he told the audience, "[w]e cannot shut our eyes to the activities of the so-called

\footnotetext{
134 Kansas City Catholic Register, 5 October 1922, 12 October 1922, 19 October 1922, 26 October 1922, 2 November 1922, 9 November 1922, 16 November 1922.

${ }^{135}$ Kansas City Catholic Register, 5 October 1922.

${ }^{136}$ Frank Vandiver, Black Jack: The Life and Times of John J. Pershing (College Station: Texas A\&M University press, 1977); Gene Smith, Until the Last Trumpet Sounds: The Life of General of the Armies John J. Pershing (New York: Wiley, 1998); Jim Lacey, Pershing: A Biography (New York: Palgrave MacMillan, 2008); Andrew Carroll, My Fellow Soldiers: General John Pershing and the Americans who helped win the Great War (New York: Penguin Press, 2017);

137 St. Louis Star, 7 December 1922; St. Louis Post-Dispatch, 12 December 1922; Kansas City Catholic Register, 14 December 1922; Kansas City Call, 15 December 1922.
} 
Invisible Empire, whose members in office disregard their public duty and allow their criminals to go unpunished." ${ }^{138}$

By the time of Pershing's critique, the Ku Klux Klan had added many new states, including Missouri, to its Invisible Empire. Yet, anti-Klan sentiments among residents, politicians, and the press had slowed the growth of the order within the state. Outside of southwestern Missouri, particularly Joplin, as well as St. Louis, the Klan endured repudiation with its recruiters turned away in a few cities. Confined largely to communities on the borders of Missouri, Klan kleagles had yet to even venture, in substantial numbers, to the central portion of the state. This would not last forever, though. If 1921 was the year the Klan established a "beachhead" in Missouri, 1922 would serve as the primary "invasion" year. While communities like Joplin, which had been seemingly receptive to the Klan, would experience new levels of opposition, the new year would also bring a change in Klan sentiment in communities like Kansas City and St. Joseph. As the Invisible Empire continued to slowly grow in the state, more and more Missourians would gaze upon the fiery cross and wonder what it meant for their communities and what they could do to stop it.

${ }^{138}$ New York Times, 6 December 1922, Ku Klux Klan - November, 1922, Folder 1, Box C-315, NAACP, LOC. 


\section{Chapter 3: "Catching Hell From All Quarters"}

In what the St. Louis Argus later referred to as a "mockery of prayer," J.F. Craig, in front of a large crowd at St. Louis' Fourth Christian Church, fell upon his knees and asked God to "bless everybody, particularly the Ku Klux Klan, for we are catching hell from all quarters."1 Craig, an Atlanta-based Klan spokesman who later admitted to falsifying his name at a local hotel because he feared the "minions of the Pope," was in the city to recruit for the Invisible Empire. He had been invited by Rev. C.C. Crawford, a local Klan official and pastor of the Fourth Christian Church, to preach to the audience about the need for one hundred percent Americanism. The need, according to Craig, was "urgent" as the enemies of the Klan had spent "millions of dollars in slandering" on an organization that was attracting "hundreds of thousands of the flower of American manhood." Ordering those in attendance to refrain from patronizing Jewish, Greek, and Italian merchants, Craig returned time and again to the subject of Americanism and patriotism, accenting his comments by kneeling in reverence before a miniature American flag he pulled from his pocket. $^{2}$

The St. Louis Post-Dispatch mocked Craig's use of "theatrical effect," particularly when he searched frantically for the misplaced flag during a dramatic climax, but the Argus took offense to his comments that African Americans should be kept "where they belong." The Argus noted the irony of Klansmen complaining about "catching hell from all quarters" and appealing to Christianity while they attacked "Jews,

\footnotetext{
${ }^{1}$ St. Louis Argus, 13 October 1922; St. Louis Post-Dispatch, 10 October 1922.

2 St. Louis Post-Dispatch, 10 October 1922.
} 
Negroes, Catholics, Greeks and all foreigners generally in a most vile and scurrilous manner." To the Argus, and many anti-Klan activists, Klansmen were not "Christian gentlemen" but "disciples of the Devil" and members of an "outlaw, race-hating, self seeking, grafting organization." "It is high time," a concerned St. Louisan wrote to the Post-Dispatch, "that our government at Washington take drastic action to dissolve this klan [sic]." Another resident advised Craig to "love thy neighbor as thyself" because "God created every one of us, Jew, Catholic, Greek, Italian and negro, with a soul made in his image and likeness of Himself." "No man can speak of the lowly Nazarine and vaunt himself in the spirit of the Ku Klux Klan," the Argus told its readers, "no man can be a good citizen and be a member of the Klan...they are one hundred per cent unAmerican...they are trying to destroy the Constitution of the United States...they desecrate the flag and take the name of the Lord in vain."

The Klan arrived in Missouri in 1921 and quickly established chapters in Joplin and St. Louis. In communities like Kansas City and St. Joseph, local police and city officials strongly rebuked hooded recruiters. Meanwhile, thanks to coverage of the hooded order in local newspapers, townspeople in Cape Girardeau, Jefferson City, Columbia, and Fulton were well aware of the movements of the Klan around the country and the state, even if the Invisible Empire had not yet come knocking on their doors. This narrative, however, changed for many communities throughout Missouri by the mid1920s. From its beachhead position on the state's border, the Klan grew inward. Kansas City residents soon found Klan chapters in neighboring communities in both Missouri

\footnotetext{
${ }^{3}$ St. Louis Post-Dispatch, 18 October 1922; St. Louis Argus, 13 October 1922.

${ }^{4}$ St. Louis Argus, 13 October 1922.
} 
and Kansas. In St. Louis, a growing local Klan, combined with support from Protestant ministers, produced a skyrocketing "hooded" population. For Joplin, the continued growth of the Klan soon brought about a call for anti-Klan mobilization from some of the town's top citizens; but not before Klansmen spread out through southwest Missouri and won over more supporters by donating nearly one thousand dollars to local "worthy" causes. ${ }^{5}$ By the end of 1922, St. Joseph, due to a groundswell of support for the Klan's "law and order" stance, saw a substantial reversal of its previous anti-Klan sentiments. A little more than a year after it first arrived in the state, Missouri's Invisible Empire seemed invincible.

While newspapers had primarily led the charge against the Klan when the group arrived in the state, a growing collection of organizations focused on civil rights, social justice, and religious toleration turned their attention towards the Invisible Empire by 1922. Though they saw the Klan as a common enemy, these groups could not unite in their fight against the hooded order. Ultimately, many of these groups formed a tenuous bond when it came to confronting the Klan, particularly in the lead up to local elections, but internal and external disagreements prevented a unified front. Nevertheless, despite the failure to form an interracial and inter-denominational alliance, most of these groups experienced some level of success in challenging the growth of the Invisible Empire. Yet, as this chapter shows, despite earlier claims that it was "catching hell from all quarters,"

\footnotetext{
${ }^{5}$ For donations made by Jasper County Klansmen see Joplin Globe, 23 February 1922, 18 March 1922, 25 March 1922, 14 April 1922, 18 April 1922, 12 October 1922, 19 October 1922, 21 October 1922, 22 October 1922, 29 October 1922, 3 November 1922, 4 November 1922, 12 November 1922, 5 December 1922, 12 December 1922, 19 December 1922, 23 December 1922, 24 December 1922. For donations made by Klansmen in northeastern Oklahoma and southeastern Kansas see Joplin Globe, 2 April 1922, 18 April 1922, 22 April 1922, 21 May 1922, 18 July 1922, 17 October 1922, 18 November 1922,
} 
and assertions from newspapers like the Kansas City Catholic Register that the hooded order was "dead" in the wake of the 1922 Election, the Klan was alive and well in the state. At the dawn of 1923, the organization continued to "catch hell" from its opponents, but anti-Klan activists soon realized that the fight to stop the growth of the Invisible Empire had only just begun.

Though there were several organizations in the United States that investigated and fought the Klan during the 1920s, this chapter focuses on seven national groups that were also active in Missouri. These organizations were the Catholic Central Verein, Knights of Columbus, American Unity League, National Urban League, National Association for the Advancement of Colored People, Universal Negro Improvement Association, and B'nai B'rith. Individually, these groups traditionally catered to the needs of their members on a variety of issues. The Central Verein, Knights of Columbus, and American Unity League had ties to Catholicism. B'nai B'rith supported Jewish causes. The Universal Negro Improvement Association focused on anti-colonialism and Black Nationalism, while the interracial NAACP and National Urban League turned their attention to the plight of people of color in the United States. Despite their individual causes, they were all prominent organizations concerned with religious and racial toleration as well as social justice. Together, at times, they fought the Invisible Empire. Founded in 1855, the German Roman Catholic Central Verein organized with the intention of being a national federation of benevolent societies. Though it was not alone in this vision during the latter half of the $19^{\text {th }}$ century, the Central Verein emerged as one 
of the preeminent organizations committed to German Catholics in the United States. ${ }^{6}$ By the early $20^{\text {th }}$ century, the Central Verein claimed a membership of roughly 125,000 members scattered throughout the United States with particular strength in New York, Pennsylvania, Illinois, Minnesota, Wisconsin, and Missouri. ${ }^{7}$ Concerned primarily with social reform, labor issues, and countering the spread of socialism in the United States, the Central Verein also took a strong stance against religious intolerance in the United States. ${ }^{8}$

In an effort to strengthen its position on social reform and intolerance, the Central Verein established a Central Bureau in St. Louis in 1908. To head the new Bureau, the Central Verein appointed Frederick P. Kenkel as the director. ${ }^{9}$ Born in Chicago in 1863 , Kenkel had been raised Catholic before distancing himself from the church as he entered adulthood. He returned to the faith following the death of his first wife in 1889, and soon became one of the preeminent voices in American Catholicism. By the time of his appointment as the Director of the Central Bureau in 1908, Kenkel was a member of the Central Verein's Committee for Heranbildung (Education) as well as the editor of one of the most influential German-Catholic newspapers in the United States, St. Louis' Die Amerika. $^{10}$

\footnotetext{
${ }^{6}$ Philip Gleason, The Conservative Reformers: German-American Catholics and the Social Order (South Bend, University of Notre Dame Press, 1968), 23-29.

${ }^{7}$ Gleason, The Conservative Reformers, 122-123.

${ }^{8}$ Gleason, The Conservative Reformers, 69-89, 125-131.

${ }^{9}$ Gleason, The Conservative Reformers, 102-115.

${ }^{10}$ Gleason, The Conservative Reformers, 91-100.
} 
At the same time that the Central Verein created the Bureau, it also established a bilingual magazine called the Central-Blatt and Social Justice. Printed in both English and German, the magazine featured articles from leading Catholics on social questions, morality, and Christianity. ${ }^{11}$ Additionally, to fit with the Central Bureau's emerging role as a clearinghouse for information related to public lectures given by fake priests and nuns, the Central-Blatt and Social Justice also devoted a portion of its pages to antiCatholicism. While this focus on anti-Catholicism largely centered on The Menace, and similar anti-Catholic newspapers, prior to World War I, by the 1920s, the Klan gained the full attention of the magazine and its readers. ${ }^{12}$

Working together, the Bureau and the Central-Blatt and Social Justice kept a close watch over the activities of anti-Catholic groups, particularly the Klan, throughout the 1920s. In a letter to Rev. G.E. Sommerhauser of St. Louis, Bureau workers warned the priest that associates with a lecturer named "Mrs. Neva Miller" had connections with the Ku Klux Klan. ${ }^{13}$ After potential libelous information was printed in the Klan publication "Fiery Cross," a member of the Convent of the Good Shepard in Fort Thomas, Kentucky, wrote to the Bureau to explain the circumstances surrounding rumors that it prevented children from seeing their relatives. ${ }^{14}$ With Kenkel at the helm, the Central Bureau advised supporters to mail in inquiries about fake Catholic lecturers or

${ }^{11}$ Gleason, The Conservative Reformers, 104-105, 117.

${ }^{12}$ Gleason, The Conservative Reformers, 117, 124.

${ }^{13}$ Central Bureau of the Central Verein to Rev. G.E. Sommehauser, 21 October 1926, Folder 1, Box 7, Central Bureau General Correspondence, Catholic Central Verein of America: Manuscripts, Catholic Central Verein of America Records, University of Notre Dame Archives, Notre Dame, IN (hereafter cited as CCV-UNDA).

${ }_{14}$ M.M. of St. John Evangelist to F.B. Kenkel, 29 April 1924, Folder 2, Box 7, Central Bureau General Correspondence, Catholic Central Verein of America: Manuscripts, CCV-UNDA. 
libelous charges against religious institutions. Writing to Father John Keyes about a fake priest in Kansas City, Kenkel reminded him that "we collect such material, and even seemingly meagre bits of information, properly pieced together, may prove of value."15 In fact, between 1900 and 1960, the Central Bureau collected data on numerous fake Catholic lecturers across the United States and dispensed the information to parishes concerned about local speakers. ${ }^{16}$

Kenkel also had a hand in the publication of the Central-Blatt and Social Justice and made sure it kept its readers abreast of the anti-Klan work of Catholics in the United States, particularly in the Klan hotbed of Indiana. ${ }^{17}$ It also published commentaries on anti-Catholicism in the United States. ${ }^{18}$ In his writings on "The Anti-Catholic Campaign,” J. Elliot Ross of Texas advised Catholics to "act more wisely and energetically than we have in the past" in order to ensure that the religious bigotry associated with the "multi-K'd bamboozlers" did not reach the levels of the APA or Know Nothings of the $19^{\text {th }}$ century. However, Ross was also quick to warn against "fight[ing] fire with fire" because "practically nothing can be done" in the midst of mass hysteria. Instead, Catholics should "keep passion down as much as possible." To Ross,

${ }^{15}$ Central Bureau of the Central Verein to Rev. John W. Keyes, 5 October 1929, Folder 3, Box 7, Central Bureau General Correspondence, Catholic Central Verein of America: Manuscripts, CCV-UNDA.

${ }^{16}$ For correspondence on fake lecturers written between 1900 and 1960, see Folders 1-3, Box 7, Central Bureau General Correspondence, Catholic Central Verein of America: Manuscripts, CCV-UNDA.

${ }^{17}$ Central-Blatt and Social Justice, September 1923, October 1923, April 1924, June 1924, July 1924, August 1924, July 1925.

${ }^{18}$ Central-Blatt and Social Justice, September 1923, October 1923, August 1924. 
the best way to defeat religious intolerance was to educate non-Catholics about the Church to offset the venom dispensed by anti-Catholic lecturers. ${ }^{19}$

In his comments to the Central-Blatt and Social Justice, Ross noted that there was a lethargic attitude among Catholics to correct the misinformation of anti-Catholic speakers and publishers. "Fifteen minutes, or ten minutes, or even five minutes a day [of studying the Catholic faith] will accomplish wonders," he told readers. ${ }^{20}$ While some Catholics, including St. Louis University’s Rev. Alphonse M. Schwitalla S.J. who argued that parochial schools successfully repelled elements of "Knownothingism and A. P. Aism," disputed this lethargy over education, it did concern others like Henry Seyfried of Indiana. ${ }^{21}$ In a speech at the annual convention of the Catholic Union of Missouri, Seyfried told the audience, including Central Bureau head Frederick Kenkel, that “[b]igotry will never die out so long as the devil lives...It is our duty not only to be on the defensive, but on the offensive, or the aggressive." He called upon those in attendance to not be passive, but to "carry high the banner of Catholicity among Americans."22

As the Central Verein moved to confront the Klan in the early 1920s, it was joined by another organization, the American Unity League (AUL), which also hoped to mobilize Americans, particularly Catholics, against the growing threat of the hooded

${ }^{19}$ Central-Blatt and Social Justice, September 1923, October 1923.

${ }^{20}$ Central-Blatt and Social Justice, October 1923.

${ }^{21}$ Official Report 1922, Missouri State Convention, Folder 86, Box 1, Catholic Central Verein of America: Printed Materials, CCV-UNDA.

22 Official Report 1923, Missouri State Convention, Folder 87, Box 1, Catholic Central Verein of America: Printed Materials, CCV-UNDA. 
order. At its core, the AUL intended to remove the mask of Klansmen by any means necessary. Founded in Chicago in 1922, the largely Catholic AUL developed a tactic of breaking into the homes, businesses, and headquarters of Klan officials and stealing the records of local klaverns. The organization also convinced ex-Klansmen to turn their records over. Once it secured this information, the AUL published the incriminating materials in its newspaper, Tolerance. While this method of identifying Klansmen did have some success, it was not without controversy. Most importantly, members broke the law by obtaining the records under unlawful circumstances. Additionally, with the mass publication of records, some Klan chapters began to produce fake membership lists in case of a raid. Not knowing about these "dummy" lists, the AUL quickly found itself in court. Most famously, gum manufacturer William Wrigley, Jr. sued the League for libel after his name appeared in Tolerance as a Klansman. Similar cases led to financial troubles for the League and weakened its power as a "Klan-busting" organization. ${ }^{23}$ Despite its early success, the AUL struggled to gain a strong foothold in Missouri. Its extra-legal attempts to gain Klan records met with some controversy in St. Louis. ${ }^{24}$ Additionally, despite speeches given by its leader Patrick O’Donnell within the state, few records exist to show if the AUL was active in Missouri. ${ }^{25}$ The only community to

\footnotetext{
${ }^{23}$ Chalmers, Hooded Americanism, 183-184; Blee, 119-120; David J. Goldberg, Discontented America: The United States in the 1920s (Baltimore: Johns Hopkins University Press, 1999), 134-135; Jenkins, Steel Valley Klan, 77-78. Historian William Jenkins has claimed that the AUL only began to recruit new members outside of Chicago in December 1922, but the establishment of the St. Joseph League suggests that AUL branches may have been set up in outside communities shortly after the organization was created.

${ }^{24}$ Patriot, 6 December 1923.

25 Patriot, 24 August 1923, 21 September 1923, 6 December 1923, 20 December 1923; Kansas City Catholic Register, 16 August 1923.
} 
experience any sort of growth of the organization was St. Joseph. The AUL's arrival seemed to shore up anti-Klan strength in the city as St. Joseph experienced substantial growth in its "hooded" population in 1922. Membership numbers, though, were hard to come by as few public Klan events had occurred in the city or county. Nevertheless, after noting rumors of Klan activity in the city, the St. Joseph Catholic Tribune warned the masked knights that "our city and county officials... are fulfilling their duties and need no prodding from the trouble-brewing 'exalted cyclops' to do so."26

In St. Joseph, the American Unity League planned to educate the population on the dangers of intolerance while also setting its sights on the local Klan. But, instead of targeting individual Klansmen, the St. Joseph League went to war with the principles and rhetoric of the Invisible Empire. It intended to attack the Klan, as the St. Louis Star suggested, by relying upon the Bill of Rights and the Constitution. ${ }^{27}$ While its impact on the St. Joseph Klan remained to be seen, the American Unity League did claim some prominent city residents among its members. ${ }^{28}$ The League had also hoped to gain the support of Governor Arthur Hyde, but he politely refused an appointment to the organization's National Committee. Though an outspoken opponent of the Klan, Hyde claimed that organizations created solely to fight the K.K.K. would actually hurt the overall anti-Klan cause by giving publicity and advertising to the Invisible Empire. ${ }^{29}$

${ }^{26}$ St. Joseph Observer, 16 September 1922; St. Joseph Catholic Tribune, 9 September 1922.

${ }^{27}$ St. Joseph Catholic Tribune, 16 September 1922, 23 September 1922.

${ }^{28}$ Kansas City Catholic Register, 21 September 1922.

${ }^{29}$ G.K. Rutledge to Arthur Hyde, 19 July 1922, Folder 366, AMH, SHS-MO; Arthur Hyde to G.K. Rutledge, 20 July 1922, Folder 366, AMH, SHS-MO. 
While the Central Verein appealed primarily to German Catholics, and the AUL attracted those who wanted to defeat the Klan by any means necessary, the Knights of Columbus had a much larger reach than either organization. Formed in 1881, the Knights of Columbus began as a fraternal organization and mutual benefit society. From its humble beginnings in New Haven, Connecticut, under the tutelage of Father Michael J. McGivney, the Knights of Columbus grew into a formidable organization that served Catholics in the United States and throughout the world. ${ }^{30}$ In addition to its fraternal work, the Knights were also deeply concerned with the image of Catholicism. With the rise of the American Protective Association in the 1890s, and the subsequent publication of several anti-Catholic newspapers in the United States, the Knights of Columbus turned its attention to religious intolerance by the early $20^{\text {th }}$ century. Soon after, its' Commission on Religious Prejudices began an extensive campaign to stamp out antiCatholic lectures, pamphlets, and newspapers. The organization's efforts met with some success (see Chapter 1), but by World War I, the commission's work was halted due to the global crisis. ${ }^{31}$

At the end of World War I, the Knights of Columbus revived its campaign against anti-Catholicism, but the arrival of the second Klan forced the organization to re-focus its attention. To combat intolerance directed at Catholics and so-called "hyphenated Americans," the Knights of Columbus launched a Historical Commission to educate Americans, particularly school children, about the contributions made by several

${ }^{30}$ Kauffman, Faith and Fraternalism, 1-28; Christopher Kauffman, Columbianism and the Knights of Columbus: A Quincentenary History (New York: Simon \& Schuster, 1992), 21.

${ }^{31}$ Kauffman, Columbianism and the Knights of Columbus, 58-59. 
ostracized groups. The Commission's actions resulted in a literature series that highlighted the work of African Americans, Jews, and German-Americans. W.E.B. DuBois' The Gift of Black Folk, George Cohen's The Jews in the Making of America, and Frederick F. Schrader's The Germans in the Making of America all highlighted the contributions of the United States' diverse population. ${ }^{32}$

In addition to the work of its Historical Commission, the Knights of Columbus also targeted the distribution of the notorious "bogus oath." While the bogus oath, a document claiming that Catholics intended to wage a bloody war against Protestants, circulated prior to the 1920s, its use by the Klan caused particular concern for the Knights. Yet, despite its goal of discrediting the oath, the Knights of Columbus found that it could not completely stop its publication. Added to this, the Knights' Supreme Advocate, Joseph Pelletier, noted that litigation against the distributors of the oath would prove extremely costly for the organization. Instead, he advised state councils to prosecute the matter at the local level. ${ }^{33}$ This decision changed, however, when Luke E. Hart won election as Supreme Advocate in 1922. ${ }^{34}$

Luke E. Hart was no stranger to the activities of the Ku Klux Klan. As a member of St. Louis' Board of Aldermen, Hart had vocally opposed the hooded order when it arrived in the city in 1921. In addition to speaking before anti-Klan meetings, Hart also

${ }^{32}$ Kauffman, Faith and Fraternalism, 261-273; Kauffman, Columbianism and the Knights of Columbus, 65.

${ }^{33}$ Kauffman, Faith and Fraternalism, 275-277.

${ }^{34}$ Kauffman, Columbianism and the Knights of Columbus, 91. 
took up the matter before the Board of Aldermen, though that body took no action. ${ }^{35}$ At the same time that he occupied a prominent position on the Board of Aldermen, Hart also rose through the ranks of the Knights of Columbus. Starting out as a knight in 1908, he became Supreme Director in 1918 before his election as Supreme Advocate in $1922 .{ }^{36}$ His primary responsibility as Advocate was to handle the organization's legal matters and serve as general counsel. After replacing Joseph Pelletier, Hart opted to take a more aggressive stance against distributors of the bogus oath, especially the Ku Klux Klan, though state councils still handled the bulk of the cases. ${ }^{37}$

Hart was also deeply involved with challenging a key education law originating in Oregon. Passed the same year as Hart's election as Supreme Advocate, Oregon's Compulsory Education Act required that all students under the age of sixteen attend a public school in the state. Intended by its supporters, particularly the Klan, to shut down parochial schools in the state, the law also shuttered many private academies. ${ }^{38}$ From the moment that it passed, however, opposition mounted against the law. This resistance was bolstered by the fact that the law would not go into effect until $1926 .^{39}$ Though the Knights of Columbus, outside of Oregon councils, initially paid little attention to the popular referendum that led to the 1922 law, the organization soon pursued legislative

\footnotetext{
35 St. Louis Argus, 30 September 1921, 14 October 1921; St. Louis Post-Dispatch, 28 September 1921, 8 October 1921, 15 October 1921; St. Louis Globe-Democrat, 28 September 1921, 8 October 1921, 15 October 1921; St. Louis Star, 8 October 1921, 15 October 1921.

${ }^{36}$ Kauffman, Columbianism and the Knights of Columbus, 91; Kansas City Catholic Register, 6 July 1922; St. Louis Star, 3 August 1921, 4 August 1921, 3 July 1922; St. Joseph Catholic Tribune, 5 August 1922.

${ }^{37}$ Kauffman, Faith and Fraternalism, 277-278.

${ }^{38}$ Kauffman, Faith and Fraternalism, 280-285.

${ }^{39}$ Kauffman, Faith and Fraternalism, 280-285.
} 
and legal options. With Hart leading the charge, the Knights of Columbus joined with other groups in opposing the law. ${ }^{40}$ In 1925 , only one year before the law was supposed to take effect, the United States Supreme Court ruled it unconstitutional in Pierce $v$. Society of Sisters. ${ }^{41}$

Historian David J. Goldberg has argued that the Oregon school law served as the primary rallying cry for Catholics to mobilize against the Invisible Empire. ${ }^{42}$ In reviewing materials from Catholic organizations, particularly the Central Verein, American Unity League, and Knights of Columbus, this assertion is legitimate. However, earlier activism against anti-Catholic groups in the $19^{\text {th }}$ and early $20^{\text {th }}$ centuries cannot be overlooked. The experience gained by Catholic leaders in confronting groups like the American Protective Association, and publications such as The Menace, served them well in their later work against the Klan. So, while organizations may have overwhelmingly confronted the Klan after passage of the Oregon school law, it should also be noted that some Catholics in Missouri, especially those affiliated with newspapers like the Kansas City Catholic Register, Church Progress, and Western Watchman, closely monitored the hooded order's growth and mobilized against it prior to 1922.

While it may have taken most Catholics until the enactment of Oregon's parochial school law to mobilize into a Klan fighting force, the African American community had a long history of opposition to the hooded order. By the early $20^{\text {th }}$ century, several prominent groups emerged with the goal of assisting African Americans, challenging Jim

\footnotetext{
${ }^{40}$ Kauffman, Faith and Fraternalism, 280-285.

${ }^{41}$ Kauffman, Faith and Fraternalism, 280-285.

${ }^{42}$ Goldberg, Discontented America, 132.
} 
Crow, and promoting black identity. Among these organizations, the National Urban League, National Association for the Advancement of Colored People, and Universal Negro Improvement Association stand out not only for their work to facilitate these goals, but also for the way they approached the rise of the second Klan. Initially voicing opposition to the hooded order, particularly through their organizational publications, each group took a different path in addressing the Klan as the 1920s wore on. The NAACP eventually emerged as the most vocal and potent Klan fighter, yet the NUL and UNIA are important to study in order to understand the larger concerns of the African American community during the 1920s.

Founded in 1910, the National Urban League (originally called the National League on Urban Conditions Among Negroes) brought several key organizations together under one roof, including the Committee on Urban Conditions Among Negroes, Committee for the Improvement of Industrial Conditions Among Negroes, and National League for the Protection of Colored Women. As separate entities, these groups had focused their attention on the plight of the nation's ever-growing black urban population. Now united together, the new Urban League continued this mission. ${ }^{43}$ While it shared many similarities with the NAACP, the Urban League refrained from the civil rights activism of its chief rival. Nevertheless, the organization worked in many American cities to improve race relations, expand housing opportunities, and ensure labor rights.

\footnotetext{
${ }^{43}$ Nancy Weiss, The National Urban League, 1910-1940 (Oxford: Oxford University Press, 1974), 29-46; Jesse Thomas Moore, Jr., A Search for Equality: The National Urban League, 1910-1961 (University Park: Pennsylvania State University Press, 1981), 46-47; Toure Reed, Not Alms But Opportunity: The Urban League and the Politics of Racial Uplift, 1910-1950 (Chapel Hill: University of North Carolina Press, 2008), 11-26.
} 
These goals became especially important as the Great Migration brought a first wave of southern-born blacks into northern communities by the dawn of World War I. ${ }^{44}$

At the close of the war, the Urban League prepared to enter the 1920s with the continued goal of improving living and working conditions in American cities. ${ }^{45}$

However, with a rise in violence and race riots, the organization also sought to establish additional chapters to prevent further conflict. ${ }^{46}$ In Missouri, the Urban League existed primarily in St. Louis and Kansas City, but by the summer of 1922, plans were underway to establish new branches in Joplin and Columbia with the possibility of others in St. Joseph, Hannibal, and Jefferson City. ${ }^{47}$ Yet, while the Urban League mobilized and expanded to confront racial violence, its main publication, Opportunity, devoted little space in its pages to the topic. ${ }^{48}$ Nevertheless, as with other publications, Opportunity did monitor the movement of the Klan throughout the United States and offered occasional commentaries on the hooded order's activities. ${ }^{49}$

Despite the lack of anti-Klan activism at the organizational level, some Urban League members, particularly Missourian Charles Ellwood, were quite vocal in their opposition to the Invisible Empire. When Ellwood's home chapter of the Urban League

${ }^{44}$ Weiss, The National Urban League, 47-138; Moore, Jr., A Search for Equality, 46-62; Reed, Not Alms But Opportunity, 11-26.

${ }^{45}$ Weiss, The National Urban League, 163-233; Moore, Jr., A Search for Equality, 64-69.

${ }^{46}$ Weiss, The National Urban League, 142-143.

47 St. Louis Post-Dispatch, 29 June 1922; Fulton Gazette, 6 July 1922; Minutes of Meeting, 3 May 1922, Reel Number C15702, Urban League of St. Louis, Inc., Missouri State Archives, Jefferson City, MO; Weiss, The National Urban League, 113, 165.

${ }^{48}$ Weiss, The National Urban League, 222-223.

49 Opportunity, January 1923, March 1923, April 1923, May 1923, July 1923, September 1923, November 1923, December 1923, January 1925, August 1925, September 1925, October 1925. 
was established in Columbia in 1922, local members received favorable press for their attempts to "remove many of the causes of friction between the races." Ellwood's role within the local Urban League is unknown, but a few white faculty members from the University of Missouri as well as several of Columbia's prominent African American ministers joined him in the organization. ${ }^{51}$ Together, they worked to keep racial antagonism at bay within Missouri, and to make Columbia the "best possible place in the United States to live." ${ }^{52}$

In addition to his work within the organization, Opportunity gave Ellwood a chance to discuss issues of intolerance. Writing on the "Menace of Racial and Religious Intolerance," Ellwood warned of a "vast secret organization... whose professed platform is anti-Catholic, anti-Jewish, anti-Negro, and anti-foreign." 53 Though not specifically naming the Klan, a general 1920s reader of Opportunity would have been well aware of which “secret organization” Ellwood was referencing. However, as became a common point of Ellwood's in his criticism of the Klan, the well-known sociologist tracked back the history of intolerance beyond the hooded order. For Ellwood, there was enough blame to go around for the activities of the Klan, yet, he was also quick to note that:

Not all of the intolerance in our country is within this organization. This organization is but a part of our intolerance. There has always been, in our country, a good deal of anti-Catholic, anti-Jewish, anti-Negro, and anti-

${ }^{50}$ Columbia Missourian, 12 June 1922.

${ }^{51}$ Columbia Missourian, 3 June 1922, 13 June 1922, 15 June 1922; Charles A. Ellwood to Eugene K. Jones, 5 May 1923, Folder: Correspondence 1923, Box 1, Charles A. Ellwood Papers (hereafter cited as CAE Papers), David M. Rubenstein Rare Book and Manuscript Library (hereafter cited as RL), Duke University, Durham, North Carolina (hereafter cited as DUKE-NC).

${ }^{52}$ Columbia Missourian, 13 June 1922.

53 Opportunity, October 1925. 
foreign prejudice. All that this organization has done has been to organize it and to bring it to expression... We know that we cannot foster any forward movement in American society without meeting this intolerance. ${ }^{54}$

Sharing many of the goals, and even membership, of the National Urban League was the National Association for the Advancement of Colored People. The momentum that eventually led to the establishment of the NAACP grew out of the stifling conditions of black life during the $19^{\text {th }}$ century. Amidst lynch mobs and the hardening of Jim Crow, a growing dissatisfaction emerged towards the accommodationist policies of Booker T. Washington. With the death of Frederick Douglass in 1895, Washington emerged as the de facto leader of the United States' African American population. However, black activists such as Ida B. Wells and W.E.B. DuBois critiqued his public image as a philanthropist and educator who seemingly kowtowed to white society and refused to critique the ever increasing epidemic of racial violence. Additionally, prominent white progressives, who had originally backed Washington, turned against him by the early $20^{\text {th }}$ century. These critics, particularly Oswald Garrison Villard, Mary White Ovington, Henry Moskowitz, Moorfield Storey, and key members of Du Bois’ Niagara Movement, eventually aligned to form the NAACP in $1909 .{ }^{55}$ By the $1920 \mathrm{~s}$, the organization claimed more than 300 branches nationwide with an estimated membership near 100,000, including seven branches in Missouri. ${ }^{56}$

\footnotetext{
${ }^{54}$ Opportunity, October 1925.

${ }^{55}$ Francis, Civil Rights and the Making of the Modern American State, 31-41; Sullivan, Life Every Voice and Sing, 1-24.

${ }^{56}$ Sullivan, Life Every Voice and Sing, 100. For information on the formation of NAACP branches in Missouri see J.H. Lawrie to W.E.B. DuBois, 26 March 1919, Folder 4, Box 1: G107, NAACP, LOC; Myrtle Cook to James Weldon Johnson, 25 April 1921, Folder 23, Box 1: G107, NAACP, LOC; Annual Report of the St. Louis Branch of the National Association for the Advancement of Colored People, 2 January 1917,
} 
Since its creation was in part a reaction to segregation, discrimination, lynching, and the failures of local, state, and national leaders to address these issues; it is not surprising that these topics became the core of the NAACP's mission. As with be discussed more in Chapter 4, the NAACP was very active in combatting the threat of lynching and the inactivity of local officials to bring mobs to justice, both in Missouri and nationwide. However, as the 1920s dawned, the NAACP also became increasingly concerned with the movement of the Ku Klux Klan throughout the United States. While never overtaking the organization's main push for litigation and legislation aimed at protecting the constitutional rights of American citizens, the group's anti-Klan crusade still proved quite effective in mobilizing people to challenge the Invisible Empire, even as the NAACP experienced limited growth during the 1920s. ${ }^{57}$

Folder 19, Box 1: G109, NAACP, LOC; A.L. Foster to Roy Nash, 3 October 1917, Folder 17, Box G111, NAACP, LOC; "Balance Sheet," 1922, Folder 10, Box G-222, NAACP, LOC; M.S. Smith to James Weldon Johnson, 22 May 1922, Folder 19, Box 1: G109, NAACP, LOC; M.S. Smith to Moorfield Story, 11 November 1922, Folder 19, Box 1: G109, NAACP, LOC; Ida Becks to James Weldon Johnson, 13 December 1921, Folder 18, Box G107, NAACP, LOC; Robert Bagnall to Robert S. Cobb, 20 May 1922, Folder 18, Box G107, NAACP, LOC; St. Louis Argus, 9 June 1922, 23 June 1922. For more information on communities interested in establishing an NAACP branch during the 1920s see H.D. Haney to Robert Bagnall, 26 April 1921, Folder 6, Box 1: G107, NAACP, LOC; R.W.B. Hayes to Roy Nash, 7 September 1917, Folder 16, Box 1: G109, NAACP, LOC. The Missouri branches included St. Louis, Kansas City, Springfield, Cape Girardeau, Caruthersville, Kirkwood, and Jefferson City.

${ }^{57}$ For examples of the NAACP campaign against the Klan see Walter White to Bella Neumann Zilberman, 16 December 1920, Folder 2, Box 1: C312, National Association for the Advancement of Colored People Collection (hereafter cited as NAACP), Library of Congress, Washington D.C. (hereafter cited as LOC); Walter White to John A. Melby, 31 January 1921, Folder 5, Box 1: C312, NAACP, LOC; Walter White to A. Clement Neal, 12 April 1921, Folder 6, Box 1: C312, NAACP, LOC; Nathan B. Young to Walter White, 5 January 1921, Folder 3, Box 1: C312, NAACP, LOC; Nathan B. Young to James Weldon Johnson, 7 January 1921, Folder 3, Box 1: C312, NAACP, LOC; Walter White to Nathan B. Young, 31 January 1921, Folder 3, Box 1: C312, NAACP, LOC; Nathan B. Young to Walter White, 27 January 1921, Folder 4, Box 1: C312, NAACP, LOC. At the time that he was communicating with the National Branch of the NAACP, Nathan Young was the President of Florida A\&M University. He became the President of Lincoln University in Jefferson City, Missouri, in 1923. 
In Missouri, this anti-Klan mobilization occurred simultaneously with the arrival of the hooded order in St. Louis in 1921. Soon after Grand Goblin Frank Crippen notified the local press of his plans for recruitment in Missouri, the St. Louis NAACP issued a statement saying that it intended to actively fight the growth of the Klan in the city. ${ }^{58}$ Local lawyer and NAACP member George L. Vaughn shared this sentiment towards activism in a letter to officials at the NAACP's National Branch. ${ }^{59}$ As Vaughn appraised the main branch of activities in St. Louis, fellow member Cora J. Carter contacted NAACP Executive Secretary James Weldon Johnson and asked for information related to the organization's attempts to remove the Klan from New York. ${ }^{6}$ Immediately responding to Carter's telegram, NAACP Assistant Secretary Walter White advised the local branch to get in contact with state chapters of the Knights of Columbus, B'nai B'rith, and the American Federation of Labor, as well as municipal and state officials, to find out their position on the Klan. Additionally, White thought it wise to convince the local press to run exposes and editorials on hooded activity in an effort to rally the entire community to the anti-Klan cause. ${ }^{61}$

While the St. Louis NAACP took the lead on fighting the Klan, similar activities occurred throughout the state. In Kansas City, the local branch closely monitored the movement of the Klan along the Missouri/Kansas border and advised the National

58 St. Louis Argus, 13 May 1921; St. Louis Star, 11 May 1921.

${ }^{59}$ George L. Vaughn to N.A.A.C.P., 16 May 1921, Folder 19, Box 1: G109, NAACP, LOC.

${ }^{60}$ Cora J. Carter to James Weldon Johnson, 13 May 1921, Western Union Telegram, Folder 19, Box 1: G109, NAACP, LOC.

${ }^{61}$ Walter White to Cora J. Carter, 13 May 1921, Western Union Telegram, Folder 19, Box 1: G109, NAACP, LOC. 
Branch that it should write an op-ed response to a Kansas City Star article about the growth of the hooded order under William Simmons. ${ }^{62}$ The Klan's recruitment in Missouri also brought a reaction from residents of Cape Girardeau who set up a meeting to discuss the organization and the lynching of Roy Hammonds in Bowling Green, Missouri. Cape Girardeau's NAACP members then issued a resolution calling on Governor Arthur Hyde to prevent "such a shameful, disgraceful and lawless organization from being legalized to operate its nefarious plans in the State of Missouri."63 Later, when a Klan recruiter was asked to leave town by Cape Girardeau mayor James A. Barks, local branch member H.N. Jones wrote to NAACP headquarters that city officials "acted so quickly that we were not given time to even call a meeting before the speaker was hurridly [sic] ejected from the city and warned never to return." ${ }^{\prime 64}$ In southwest Missouri, a threatening letter from Springfield Klan No. 12 to Dr. James B. Clark brought an inquiry from the NAACP. Clark, whose wife Pearl was involved in the local NAACP, was warned that "White girls and colored Doctors should stay apart" after it was rumored that he performed secret abortions. Walter White called upon the Chief Inspector of the Postal Service to investigate the letter, but mail officials advised White and Clark to handle the matter with local law enforcement. ${ }^{65}$

\footnotetext{
62 John Love to James Weldon Johnson, 17 May 1921, Folder 23, Box 1: G107, NAACP, LOC. For the Klan article featured in the Star see Kansas City Star, 13 May 1921.

${ }^{63}$ St. Louis Argus, 3 June 1921. The committee that composed the petition included Rev. S.M. Arthur, C.A. Curry, Rev. W.H. Hill, A.M. Oliver, R. Holloway, and Mrs. E.A. Drasdall.

${ }^{64}$ H.N. Jones to N.A.A.C.P., 16 December 1922, Folder 4, Box 1: G107, NAACP, LOC.

65 Springfield Klan No. 12 to James B. Clark, 17 July 1923, Folder 2, Box 1: C313, NAACP, LOC; James B. Clark to William Pickens, 19 July 1923, Folder 2, Box 1: C313, NAACP, LOC; Walter White to James B. Clark, 25 July 1923, Folder 2, Box 1: C313, NAACP, LOC; Walter White to Chief Inspector of Post Office Department, 26 July 1923, Folder 2, Box 1: C313, NAACP, LOC; Chief Inspector of Post Office Department to NAACP, 3 August 1923, Folder 2, Box 1: C313, NAACP, LOC; Walter White to James B. Clark, 8 August
} 
Perhaps the biggest achievement by the Missouri NAACP in its fight against the Klan was the successful recruitment of Governor Arthur Hyde. Since his gubernatorial election, the NAACP had hounded Hyde to take up the cause of African Americans in the state. This pressure intensified in the wake of the Roy Hammond lynching in 1921 and as the Dyer Anti-Lynching Bill languished in Congress in early $1922 .{ }^{66}$ It was in the midst of direct correspondence between Hyde and James Weldon Johnson on these issues that St. Louis member Cora Carter, herself quite involved in the anti-Klan campaign, asked the governor if he would be interested in joining the NAACP. ${ }^{67}$ Hyde accepted the offer, though it did not get much attention in the press at the time. With the governor enrolled as a "Contributing Member," NAACP officials no doubt felt certain that Hyde would be more likely to approach racial issues, particularly those surrounding the Klan, with the same goals as the organization. ${ }^{68}$

1923, Folder 2, Box 1: C313, NAACP, LOC; Walter White to James B. Clark, 22 November 1923, Folder 3, Box 1: C313, NAACP, LOC.

${ }^{66}$ For letters about Roy Hammond lynching see James Weldon Johnson to Arthur Hyde, 30 April 1921, Folder 105, AMH, SHS-MO; John L. Love to Arthur Hyde, 1 May 1921, Folder 105, AMH, SHS-MO; Walter White to Arthur Hyde, 26 May 1921, Folder 105, AMH, SHS-MO; Arthur Hyde to Walter White, 1 June 1921, Folder 105, AMH, SHS-MO; James Weldon Johnson to Arthur Hyde, 30 April 1921, Folder 12, Box C361, NAACP, LOC; James Weldon Johnson to Arthur Hyde, 26 May 1921, Folder 12, Box C361, NAACP, LOC; Arthur Hyde to James Weldon Johnson, 1 June 1921, Folder 12, Box C361, NAACP, LOC. For letters on the Dyer Anti-Lynching Bill see James Weldon Johnson to Arthur Hyde, 8 February 1922, Folder 106, AMH, SHS-MO; James Weldon Johnson to Arthur Hyde, 4 March 1922, Folder 106, AMH, SHS-MO; Executive Secretary of Arthur Hyde to James Weldon Johnson, 10 March 1922, Folder 106, AMH, SHS-MO; L.C. Dyer to Arthur Hyde, 13 March 1922, Folder 106, AMH, SHS-MO; Executive Secretary of Arthur Hyde to L.C. Dyer, 15 March 1922, Folder 106, AMH, SHS-MO. For additional letters asking Hyde to aid the Dyer Bill see J.M. Batchman to Arthur Hyde, 14 May 1922, Folder 106, AMH, SHS-MO; J.E. McCulloch to Arthur Hyde, 29 June 1922, Folder 106, AMH, SHS-MO; Edmund Koeln to Arthur Hyde, 10 July 1922, Folder 106, AMH, SHS-MO; J.E. McCulloch to Arthur Hyde, 25 July 1922, Folder 106, AMH, SHS-MO.

${ }^{67}$ Cora Carter to Arthur Hyde, 26 February 1922, Folder 106, AMH, SHS-MO.

${ }^{68}$ Arthur Hyde to Cora Carter, 27 February 1922, Folder 106, AMH, SHS-MO; "Membership Certificate of Arthur Hyde," 1 March 1922, Folder 106, AMH, SHS-MO; St. Louis Argus, 23 June 1922. 
Despite its success in mobilizing against the Klan, the NAACP found itself in a period of decline during the 1920 s due to efforts by some states to suppress the group. ${ }^{69}$ Additionally, a new organization, the Universal Negro Improvement Association (UNIA), threatened to siphon members from the NAACP. Founded a few years after the NAACP and Urban League in 1914, the UNIA was the creation of Marcus Garvey. Born in Jamaica in 1887, Garvey traveled the world at a young age and became a strong advocate for Black Nationalism. While fighting for similar causes as the NAACP and Urban League in the United States, the UNIA under Garvey also promoted self-reliance, racial uplift, and a "back to Africa" movement that encouraged de-colonialism and nationhood. $^{70}$ By the 1920 s, divisions of the UNIA existed throughout the United States, particularly along the Atlantic coast and the Deep South, with its central headquarters located in Harlem. In addition to its members in the United States, the UNIA also claimed widespread support among people of African ancestry around the globe and its main publication, Negro World, distributed roughly half a million copies each week to its international audience. $^{71}$

While it mainly focused its organizational attention on Black Nationalism and racial uplift, the UNIA also kept an eye on the growth of the Ku Klux Klan in the United States. When it was rumored that the Klan planned on recruiting members in New York,

${ }^{69}$ Sullivan, Life Every Voice and Sing, 61-100; Mary G. Rolinson, Grassroots Garveyism: The Universal Negro Improvement Association in the Rural South, 1920-1927 (Chapel Hill: University of North Carolina Press, 2007), 173.

${ }^{70}$ Colin Grant, Negro with a Hat: The Rise and Fall of Marcus Garvey (Oxford: Oxford University Press, 2008), 52-317.

${ }^{71}$ Rolinson, Grassroots Garveyism, 72-102; Judith Stein, The World of Marcus Garvey: Race and Class in Modern Society (Baton Rouge: Louisiana State University Press, 1986), 108-152. 
Garvey publicly warned the group that the state's black population would fight against such an action. ${ }^{72}$ The Negro World, with Garvey at the helm, also informed its readers about the movement of the Klan throughout the United States, particularly when antiKlan groups sought to challenge the Invisible Empire. ${ }^{73}$ In February 1921, the Negro World ran an advertisement for an anti-Klan mass meeting in New York City featuring prominent labor activists such as A. Philip Randolph, Chandler Owen, Elizabeth Girley Flynn, and Paul Robeson. ${ }^{74}$ After reprinting a series of articles from the New York World's expose on the group, the Negro World editorialized that "[i]f...the present $\mathrm{Ku}$ Klux Klan is a patriotic, law-abiding and peace-loving organization, why does it take the name and don the mask of the infamous organization of 1868 ?"75

Despite the UNIA's tough talk against the Klan in the early 1920s, Marcus Garvey soon moved in a different direction regarding the Invisible Empire. In June of 1922, Garvey held a secret meeting with E.Y. Clarke, Klan Imperial Wizard William Simmons' second in command. ${ }^{76}$ An accurate depiction of the meeting is hard to come by as Garvey was the only one to publicly acknowledge the gathering. Simmons remained silent on the subject, and ultimately faced internal pressure from other Klan

72 Rolinson, Grassroots Garveyism, 145; Stein, The World of Marcus Garvey, 159; Grant, Negro with a Hat, 334-335.

${ }^{73}$ Negro World, 21 February 1921, 9 April 21, 16 April 1921, 18 June 1921, 2 July 1921, 9 July 1921, 20 August 1921, 3 September 1921, 10 September 1921, 17 September 1921, 1 October 1921, 8 October 1921, 22 October 1921, 29 October 1921, 25 March 1922.

${ }^{74}$ Negro World, 21 February 1921.

${ }^{75}$ Negro World, 29 October 1921.

${ }^{76}$ Rolinson, Grassroots Garveyism, 143-146; Stein, The World of Marcus Garvey, 154-158; Grant, Negro with a Hat, 333-334. 
officials for meeting with Garvey. ${ }^{77}$ In his front page editorial in the July $22^{\text {nd }}$ edition of the Negro World, Garvey defended the meeting as an attempt to gain "first-hand information about the Klan's attitude toward the race I represent."78 However, in the month between his meeting with Clarke and the defensive editorial of July 22nd, Garvey and the Negro World repeatedly offered no resistance to the actions of the Klan across the country. On July $1^{\text {st }}$, after discussing a letter allegedly sent to an Omaha black newspaper by the local Klan, Garvey argued that "the bitterest enemy of the Negro is not the white man [or] Ku Klux Klan, but the Negro himself."79

The theme that the United States was a "white man's country" came up often in Garvey's defense of the Klan, and he was quick to remind his followers that groups actively fighting the Invisible Empire, particularly the NAACP, were out of touch with the wishes of African Americans. ${ }^{80}$ "Our Du Boises [sic], Johnsons et al. are living in the air," the Negro World proclaimed, "they are as far from understanding the Negro problem of America and the western world as a monkey in understanding how far Mars is from Jupiter." 81 Instead, Garvey advised the nation's black population "not to 'antagonize' [the Klan], not to petition Congress about it, not to obstruct its activities, but to organize, to organize in our own behalf!"82

\footnotetext{
77 Rolinson, Grassroots Garveyism, 145-146; Stein, The World of Marcus Garvey, 159; Grant, Negro with a Hat, 333-334.

78 Rolinson, Grassroots Garveyism, 145-146; Stein, The World of Marcus Garvey, 159; Grant, Negro with a Hat, 333-334.

${ }^{79}$ Negro World, 1 July 1922.

${ }^{80}$ Negro World, 1 July 1922, 15 July 1922, 22 July 1922, 29 July 1922, 5 August 1922.

${ }^{81}$ Negro World, 1 July 1922.

${ }^{82}$ Negro World, 15 July 1922.
} 
In reviewing the circumstances around the meeting, scholars have speculated about the reasoning behind both men's agreement to talk in Atlanta. Judith Stein argues that Garvey wanted to expand the UNIA further into the South during the early 1920s so he "accommodated to regional ways" and "publicly praised Jim Crow." 83 According to Stein, Garvey's compliance with Jim Crow caught the attention of Clarke who agreed to a meeting in the hopes that it would reinforce the Klan's preferred image of patriotic reformers instead of moral vigilantes. ${ }^{84}$ Agreeing in part with Stein's assessment, Mary G. Rolinson notes that Garvey and Clarke both shared an opposition to miscegenation and felt that something needed to be done to stop interracial rape. ${ }^{85}$ Garvey's position on the subject gained him support among some white southerners, and the UNIA experienced less harassment in its organizing in the region then its chief rival, the NAACP, due to his stance on racial issues ${ }^{86}$ However, one cannot overlook that around the same time as his meeting with the Clarke, Garvey was preparing for the UNIA's $3^{\text {rd }}$ Annual Convention of Negroes in Harlem. ${ }^{87}$ As Colin Grant points out, troubles endured by the UNIA during the early 1920s, particularly those centering on his arrest for mail fraud, may have pushed Garvey into a new path to stabilize the organization. ${ }^{88}$ When this is considered, it becomes quite probable that Garvey knew that the controversy around

${ }^{83}$ Stein, The World of Marcus Garvey, 153-154.

${ }^{84}$ Stein, The World of Marcus Garvey, 154-158.

${ }^{85}$ Rolinson, Grassroots Garveyism, 143-144.

${ }^{86}$ Rolinson, Grassroots Garveyism, 143-146, 173.

${ }^{87}$ Negro World, 1 July 1922, 8 July 1922, 15 July 1922, 22 July 1922, 29 July 1922, 5 August 1922; Grant, Negro with a Hat, 338-348.

${ }^{88}$ Grant, Negro with a Hat, 320. 
the meeting would impact recruitment and turn public attention towards the UNIA's "back to Africa" movement as it met for the convention.

Whatever his reason behind the meeting, Garvey, for his part, received intense condemnation from several prominent black leaders. Uniting behind groups like the NAACP and Urban League, a major "Garvey Must Go" campaign soon followed his meeting with Clarke. Though the discussion with Clarke was not the only reason behind the campaign, Garvey's peculiar support and embrace of the Klan fanned the flames of a fire that had started when opposition leaders like A. Philip Randolph and Chandler Owen felt that he was ignoring racial issues in the United States in favor of his support for PanAfricanism. Garvey also publicly challenged the NAACP and threatened to siphon members at a time when the organization was entering a rough patch in recruiting. It is not surprising then that the NAACP took part in the "Garvey Must Go" campaign considering the tumultuous relationship between it and the UNIA, but that William Pickens, one of his key allies, took part caught Garvey off guard. ${ }^{89}$

William Pickens, despite his role as a field organizer for the NAACP, was a supporter of Marcus Garvey. Before joining the NAACP in an official capacity, he had even contemplated joining the UNIA. ${ }^{90}$ However, his support for Garvey was tested following the June 1922 meeting. When offered a special invitation by Garvey to an upcoming UNIA ceremony, Pickens declined citing that though "the U. N. I. A. is not...in a class with those criminal organizations...I gather from your recent plain

\footnotetext{
${ }^{89}$ Rolinson, Grassroots Garveyism, 146-147; Stein, The World of Marcus Garvey, 158-170; Grant, Negro with a Hat, 334-338.

${ }^{90}$ Rolinson, Grassroots Garveyism, 146-147; Stein, The World of Marcus Garvey, 163-166; Grant, Negro with a Hat, 334-338.
} 
utterances you are now endorsing the Ku Klux Klan."91 In grilling Garvey over his supposed support for the Klan, Pickens noted that the rank and file members of the UNIA's many divisions would not stand for such an alliance with the Invisible Empire. As he closed his letter, Pickens offered an outright rejection of any honorary title that the UNIA or Garvey might bestow upon him in the future and argued that he "would rather be a plain black American fighting in the ranks AGAINST the Klan and all its brood than to be the Imperial wizard of the Ku Klux of the allied Imperial Blizzard of the U. N. I. A." 92

William Pickens' comments, combined with information on the larger "Garvey Must Go" movement received coverage in Missouri newspapers, particularly in communities with UNIA divisions. Both the St. Louis Post-Dispatch and St. Louis Star relayed the allegations put forth by Garvey's critics to their readers. ${ }^{93}$ The St. Louis Argus reprinted Pickens' letter to Garvey where he criticized the UNIA leader for his sentiments on the Klan. ${ }^{94}$ However, despite the attention paid to the "Garvey Must Go" campaign, it is unknown how Garveyites in Missouri responded to their leader's comments on the Klan. While Garvey's earlier denunciations of the Klan no doubt inspired his followers to join in anti-Klan protests, the continued support for the UNIA in

\footnotetext{
${ }^{91}$ St. Louis Argus, 28 July 1922.

92 St. Louis Argus, 28 July 1922.

93 St. Louis Post-Dispatch, 2 August 1922; St. Louis Star, 1 August 1922, 7 August 1922.

94 St. Louis Argus, 28 July 1922.
} 
St. Louis, Kansas City, and the state's southeastern Cotton Belt, following the 1922 meeting, suggests that members did not flee the organization over the Klan issue. ${ }^{95}$

The decision of Missouri UNIA members to continue to align with the organization despite the growing opposition to Garvey's activities is significant considering the anti-Klan sentiment within the state and the growth of the Invisible Empire in communities with UNIA divisions. Members stayed strong in southeast Missouri even after Garvey responded to violent threats made against black laborers in the region by advising them that "this is a white man's country" and they should focus their attention on "the building up of a country of their own."96 Despite the continued success of the UNIA in the midst of the "Garvey Must Go" campaign, its central figure struggled with internal and external issues for the rest of the 1920s. Following his conviction for mail fraud, members of the "Garvey Must Go" campaign got their wish when Marcus Garvey was deported from the United States in $1927 .{ }^{97}$ The central offices of the UNIA moved from Harlem to Jamaica and eventually to London following his deportation, but the organization struggled to maintain its recruiting success as the decade wore on. ${ }^{98}$

${ }^{95}$ For information on UNIA activity in Missouri see Roll, Spirit of Rebellion, 52-75; Negro World, 26 March 1921, 16 April 1921, 5 November 1921, 10 December 1921, 11 March 1922, 25 March 1922; St. Louis Post-Dispatch, 27 May 1921, 6 June 1921, 21 October 1922, 9 February 1925, 18 August 1925, 2 May 1926, 31 March 1929; St. Louis Star, 2 March 1922, 18 December 1922, 6 October 1922; St. Louis Argus, 18 February 1921, 11 March 1921, 8 April 1921, 15 April 1921, 3 March 1922, 19 May 1922, 28 July 1922; Kansas City Call, 4 March 1922, 11 March 1922, 13 May 1922, 10 June 1922.

${ }^{96}$ Negro World, 10 March 1923.

${ }^{97}$ Grant, Negro with a Hat, 388-412.

${ }^{98}$ Grant, Negro with a Hat, 413-450. 
Just as African American organizations experienced division over how to address the growth of the Klan, so too were American Jews unsure about the best way to mobilize against the Invisible Empire. However, one group, the Independent Order of B'nai B'rith, emerged as the most vocal proponent of battling anti-Semitism. Founded earlier than other anti-Klan organizations, the Independent Order of B'nai B'rith formed in New York City by German Jews in $1843 .{ }^{99}$ Much like these other organizations, B'nai B'rith began as a fraternal group with community improvement as its main goal. Additionally, the group offered key benefits for those who held membership. Throughout the first fifty years of its existence, B'nai B'rith built a strong foundation around protecting Jewish rights in the United States and worldwide. ${ }^{100}$ At the dawn of the $20^{\text {th }}$ century, B'nai B'rith turned its attention towards growing anti-Semitic sentiment nationwide. One of the biggest incidents to garner the organization's attention was the trial of Atlanta businessman Leo Frank for his alleged role in the murder of Mary Phagan. Frank, who was Jewish, experienced extreme anti-Semitism during the trial. After Georgia's governor commuted Frank's guilty sentence to life imprisonment, a mob kidnapped Frank and lynched him in nearby Marietta. ${ }^{101}$

Though formed before the trial and lynching of Leo Frank, B'nai B'rith established the Anti-Defamation League (ADL) as an auxiliary of the main organization

99 Deborah Dash Moore, B'nai B'rith and the Challenge of Ethnic Leadership (Albany: State University Press of New York, 1981), 1-13.

100 Moore, B'nai B'rith and the Challenge of Ethnic Leadership, 102-106.

101 Moore, B'nai B'rith and the Challenge of Ethnic Leadership, 102-119; MacLean, Behind the Mask of Chivalry, 12. 
to combat anti-Semitism. ${ }^{102}$ The circumstances surrounding Frank's death became the central focus of the ADL in its early years, though this was not its sole campaign. The ADL also turned its attention to an article series published in Henry Ford's Dearborn Independent entitled "The International Jew." Inspired by The Protocol of the Learned Elders of Zion and Werner Sombart's The Jews and Modern Capitalism, and crafted by Ford associates Ernest G. Liepold and William J. Cameron, "The International Jew" examined an alleged conspiracy undertaken by Jewish leaders to influence and dominate global affairs. ${ }^{103}$ In response to “The International Jew," B'nai B'rith and the ADL launched a series of pamphlets objecting to the articles' blatant anti-Semitism and calling on prominent Americans to denounce Henry Ford. This campaign met with moderate success, though Ford did not immediately remove the content from his Dearborn Independent. ${ }^{104}$

By the 1920s, at the same time that the ADL waged war against Henry Ford, the organization confronted a new threat in the Ku Klux Klan. With the rise of the Klan out of the American South, the ADL became more politically active as a means to prevent anti-Semitic legislation. Yet, despite its activism, historian Deborah Dash Moore has noted that the ADL was relatively weak in the 1920 s compared to the Klan. The

102 Moore, B'nai B'rith and the Challenge of Ethnic Leadership, 106-109.

103 Moore, B'nai B'rith and the Challenge of Ethnic Leadership, 115-117; Leo P. Ribuffo, "Henry Ford and The International Jew," in The American Jewish Experience: Second Edition, ed. Jonathan D. Sarna (New York: Holmes \& Meier, 1997), 201-216; Steven Watts, The People's Tycoon: Henry Ford and the American Century (New York: Alfred A. Knopf, 2005), 376-397; Vincent Curcio, Henry Ford (Oxford: Oxford University Press, 2013), 131-158.

${ }^{104}$ Moore, B'nai B'rith and the Challenge of Ethnic Leadership, 115-117. 
organization found some minor success in its campaign against the Klan, but overall, the ADL and B'nai B'rith could do little to stop the spread of the Invisible Empire. ${ }^{105}$

While American Jews mustered only limited success against the Klan nationwide, their brethren in Missouri still actively worked against anti-Semitism and the hooded order. Jews had lived in Missouri since the earliest days of the state, but it was not until 1855 that St. Louis established the first B'nai B'rith lodge. ${ }^{106}$ Kansas City soon followed with its own lodge in 1868 , and by the early $20^{\text {th }}$ Century, Jews could be found throughout the state, though most tended to live in urban communities. ${ }^{107}$ In 1921 , the St. Louis Board of Aldermen considered a bill pushed by prominent local Jews, including Missouri ADL chairman Abraham Rosenthal, to levy a fine on publications, specifically the Dearborn Independent and the anti-Catholic New Menace, that attacked any race or religion. ${ }^{108}$ City policemen soon began arresting anyone selling the Dearborn Independent, but the local press heavily criticized the policy. ${ }^{109}$

\footnotetext{
105 Moore, B'nai B'rith and the Challenge of Ethnic Leadership, 116-119.

${ }^{106}$ Walter Ehrlich, Zion in the Valley: The Jewish Community in St. Louis, Volume 1, 1807-1907 (Columbia: University of Missouri Press, 1997), 111-112.

107 Howard F. Sachs, "Development of the Jewish Community of Kansas City, 1864-1908," Missouri Historical Review 60 no. 3 (April 1966), 350-360; Joseph Schultz, ed., Mid-America's Promise: A Profile of Kansas City Jewry (Kansas City: The Jewish Community Foundation of Greater Kansas City, 1982); Lee Shai Weissbach, Jewish Life in Small-Town America (New Haven: Yale University Press, 2005), 2, 54; Anne Hessler, German Jews in Small Towns in Missouri, 1850-1920 (Master's Thesis: University of Missouri-Columbia, 1991); Sandra Rubinstein Peterson, "One Heart, Many Souls": The National Council of Jewish Women and Identity Formation in St. Louis, 1919-1950 (Ph.D. Diss.: University of MissouriColumbia, 2008), 1-74.

108 St. Louis Post-Dispatch, 5 March 1921; St. Louis Star, 5 March 1921.

109 St. Louis Post-Dispatch, 18 March 1921, 19 March 1921, 28 March 1921, 29 March 1921, 8 April 1921, 29 April 1921, 20 May 1921, 21 May 1921, 26 May 1921, 4 June 1921, 5 June 1921, 7 June 1921; St. Louis Star, 18 March 1921, 19 March 1921, 28 March 1921, 29 March 1921.
} 
Though the Jewish Voice supported the arrests of those connected to the Dearborn Independent, it was unsure how to address St. Louis' growing Klan population that likely read the targeted newspapers. ${ }^{110}$ When an alleged Klan document emerged suggesting that members fire Jewish employees and boycott Jewish businesses, the newspaper asked Imperial Wizard William Simmons to "give us the official attitude of the Klan towards the Jews." 111 After receiving a reply from Klan leaders in two eastern states, the Jewish Voice assured its readers that the organization's official literature was not antagonistic to Jews. ${ }^{112}$ The Kansas City Jewish Chronicle disagreed with the newspaper's conclusion and argued that the Klan's “anarchistic policy...in addition to their outrages in defiance of the courts and the Constitution of America...is sufficient to condemn them," but The Modern View initially sided with the Jewish Voice in its stance that the Klan was not anti-Jewish. ${ }^{113}$ Abraham Rosenthal, Missouri ADL chairman and editor of Modern View, expressed the belief that the Klan did not have "real or radical illwill toward any self-respecting, law-abiding Jew."114 Reprinting Imperial Wizard Hiram Evans' comments that the Klan was not antagonistic to Jews, Modern View left it "to the judgment of our readers." 115 The newspaper soon changed its opinion, however, after comments emerged, allegedly from Klan officials, claiming that Jews were un-blendable and un-American. This "vile libel," according to Modern View, showed "malice and

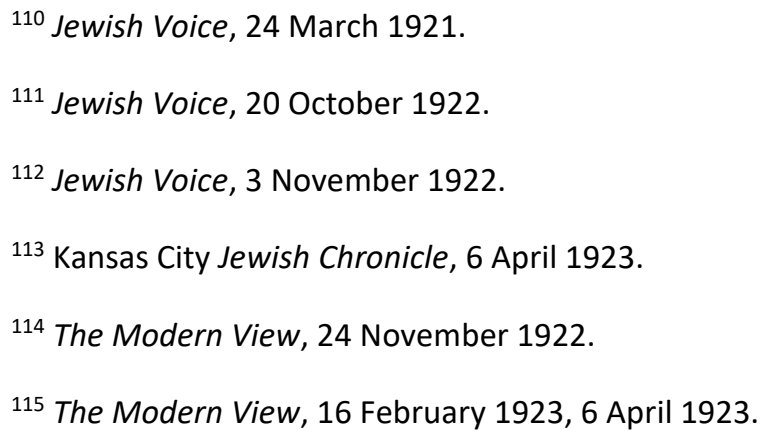


ignorance" towards Jews. "While its antagonism and narrow, bigoted opposition to the Jewish people had long been no secret to anyone who followed the un-American tactics of the masked mob," the Klan was now "unmasked" and all of its prejudice revealed. ${ }^{116}$ As is indicated by the shift in opinions about hooded activities among Missouri Jewish newspapers, anti-Klan groups were bolstered by the investigative work and editorial commentaries of the press. Like their prior efforts in 1921, anti-Klan newspapers kept their readers abreast of the movements of the Klan around the country in 1922 and continued to pressure politicians and local officials to "speak out" in condemnation of the Invisible Empire. With the August primaries and November election looming, rumors of Klan infiltration into politics deeply concerned the anti-Klan press. The Argus overwhelmingly favored transparency among political candidates and looked forward to the "determined efforts on the part of some state officials to stamp out the activities of the Klan." ${ }^{117}$ But, the Argus also worried that the warnings and calls to action issued by the press the previous year had fallen on "deaf ears."118 With this in mind, it is not surprising then that the Argus, and other newspapers, targeted Missouri's US Senate race in 1922 as a key battleground in the war against the Klan.

The campaign for James A. Reed's US Senate seat proved to be the defining race of the 1922 election in Missouri. As the Democratic incumbent, Reed knew he would face an intense challenge from state Republicans aligned with Governor Arthur Hyde, particularly William Sacks and R.R. Brewster. Yet, if Reed hoped to take on either Sacks

\footnotetext{
116 The Modern View, 2 November 1923.

117 St. Louis Argus, 28 April 1922.

${ }^{118}$ St. Louis Argus, 7 July 1922.
} 
or Brewster in the general election, he would have to make it through his own party's primary first. This proved to be no easy task as Reed's opposition to the League of Nations and disregard for the policies of former President Woodrow Wilson made him a pariah among Democrats. ${ }^{119}$ On more than one occasion, Wilson publicly denounced Reed and hinted that a more qualified candidate deserved his seat. ${ }^{120}$ Seeking to replace Reed, state Democratic leaders opted to back Breckinridge Long, former Assistant Secretary of State under Wilson. To pro-Wilson Democrats, Long was everything that Reed was not: an adherent of Wilson, supporter of the League of Nations, and a backer of party unity. ${ }^{121}$

With a budding rivalry between himself and Long, and as party leaders all but turned their back on him, Reed had to secure a strong coalition of voters to win reelection. The old pro knew just what to do. Having previously served as the mayor of Kansas City, Reed leaned heavily on his ties to the Pendergast and Shannon political machines for backing. The machines did not disappoint, and Reed entered the summer of 1922 with confidence that white ethnic urban voters, particularly those that opposed Prohibition, would win him the cities. ${ }^{122}$ After locking down the urban vote, Reed turned to the rural sections. In an effort to outflank Long, Reed pitched himself as a friend of the farmer. He knew he did not need to carry the rural counties, but enough handshakes

\footnotetext{
119 Mitchell, Embattled Democracy, 16-19; Franklin D. Mitchell, "The Re-Election of the Irreconcilable James A. Reed," Missouri Historical Review 60 no. 4 (July 1966), 416-417.

${ }^{120}$ Mitchell, Embattled Democracy, 46-50; Mitchell, "The Re-Election of the Irreconcilable James A. Reed," 422-424.

121 Mitchell, Embattled Democracy, 43-50; Mitchell, "The Re-Election of the Irreconcilable James A. Reed," 417-423. Reed," 428.

122 Mitchell, Embattled Democracy, 54; Mitchell, "The Re-Election of the Irreconcilable James A.
} 
could secure the votes to neutralize Long's out-state base. ${ }^{123}$ The tactic worked. Reed won by a slim margin of six thousand votes, though historian Franklin D. Mitchell has argued that Republican voters may have had a hand in the senator's victory since the state did not effectively enforce its closed primary. ${ }^{124}$

On the Republican side, there was similar party dissension as the Democrats with eight candidates vying to oppose Reed. ${ }^{125}$ Of these candidates, two emerged as the preferred challengers - William Sacks and R.R. Brewster. Sacks, a St. Louis banker, had substantial backing in the city due to his close ties with Mayor Henry Kiel. ${ }^{126}$ However, though Sacks was an ardent Republican and supporter of the Dyer Anti-Lynching Bill, the Argus opposed him due to his business ties in Texas. As that state was the "hot-bed of Ku-Kluxism, lynching, [and] burning mob-murder," the editors were troubled by Sacks" "southern" background. The Argus made sure to recuse itself of any libel, though, by noting that it did not charge that Sacks was a Klansman, only that he never spoke out against the Klan. ${ }^{127}$ After drawing heat from members of St. Louis' African American community for its attack on Sacks, the Argus wondered how these individuals, especially a few prominent local ministers, could support "Mr. Sacks' Beer and Wine Platform,"

${ }^{123}$ Mitchell, Embattled Democracy, 53-54; Mitchell, "The Re-Election of the Irreconcilable James A. Reed," 426-427.

${ }^{124}$ Mitchell, Embattled Democracy, 56-57; Mitchell, "The Re-Election of the Irreconcilable James A. Reed," 430-431.

125 Jefferson City Daily Democrat-Tribune, 22 June 1922.

${ }^{126}$ Mitchell, Embattled Democracy, 55; Mitchell, "The Re-Election of the Irreconcilable James A. Reed," 429-430; St. Louis Post-Dispatch, 1 June 1922; St. Louis Star, 1 June 1922, 12 June 1922.

${ }^{127}$ St. Louis Argus, 21 July 1922. 
because after all, "fill a mob with wine and hell can't stop it."128 In opting to oppose Sacks, the Argus threw its support behind R.R. Brewster. ${ }^{129}$

A successful lawyer from Kansas City, Brewster built a strong coalition to defeat not only Sacks and the other Republican candidates, but also James Reed. As indicated by the Argus' endorsement, Brewster was seen as favorable to black Republican voters. ${ }^{130}$ Additionally, his substantial Kansas City ties, particularly the endorsement of prominent newspaper owner Walter S. Dickey, offered a significant chance to neutralize Reed's hometown support. ${ }^{131}$ He also played up his backing for Prohibition to demonstrate his "dry" stance versus the "wet" sentiments of Sacks and Reed. ${ }^{132}$ Finally, by all accounts, he was the preferred candidate of Governor Hyde who controlled the state Republican Party. ${ }^{133}$ By July, Brewster's campaign seemed to be an unstoppable force and his central message turned to the "bad blood" within Democratic ranks compared to "peace, harmony, and friendship" amongst Republicans. ${ }^{134}$ In the August primary, Brewster ran far ahead of the eight man field, including his closest challenger William Sacks. ${ }^{135}$

${ }^{128}$ St. Louis Argus, 28 July 1922.

${ }^{129}$ St. Louis Argus, 28 July 1922; Kansas City Call, 22 July 1922, 5 August 1922.

130 St. Louis Argus, 28 July 1922.

${ }^{131}$ St. Louis Post-Dispatch, 18 June 1922; St. Louis Star, 19 June 1922.

132 Mitchell, "The Re-Election of the Irreconcilable James A. Reed," 429, 423-433.

133 St. Louis Star, 19 June 1922.

${ }^{134}$ St. Louis Post-Dispatch, 11 June 1922; St. Louis Star, 11 June 1922.

135 St. Louis Post-Dispatch, 3 August 1922; St. Louis Star, 3 August 1922; Kansas City Star, 2 August 1922, 3 August 1922, 4 August 1924; Kansas City Journal, 3 August 1922, 4 August 1922. 
Though it was Prohibition, not the Invisible Empire, which emerged as the major issue in the state's 1922 election cycle, the specter of Klan political mobilization nationwide left many to wonder if the hooded order would court candidates prior to November. The Argus warned "Local, State, or National constituted authorities" that they "should not for one moment relax their efforts to swat the Ku Klux Klan wherever that monstrous organization shows its head." ${ }^{" 136}$ Noting the electoral success of the Klan in Oregon, the St. Louis Post-Dispatch declared that "when an organization chartered on intolerance and mob violence...can obtain possession of the government by offering public spoils to this interest and that, to this class and that, the days of American democracy are numbered." Looking back to the "high principles" of men like "Jefferson, Hamilton, Franklin, and Marshall," the Post-Dispatch added that such organizational intolerance could lead to "despotism of classes not unlike that of Russia."137 Agreeing with the Post-Dispatch, the Jewish Voice lamented that "this nation cannot encourage hatred and prejudice and elect public officials on such a platform if it is to retain its respect...the deadliest blow that has been struck against the forces of Liberty in this country is the victory of the Ku Klux Klan..."138

While the US Senate race would be a statewide campaign, most of the animosity surrounding it centered on Reed and Brewster's hometown of Kansas City. As late summer turned to fall, uneasiness fell over the city. Combustion was imminent and the slightest transgression would spark the flame. The publication of a Klan business

\footnotetext{
${ }^{136}$ St. Louis Argus, 11 August 1922.

${ }^{137}$ St. Louis Post-Dispatch, 2 August 1922.

138 Jewish Voice, 4 August 1922.
} 
directory (discussed in Chapter 2) left many merchants wondering if their bottom-line would be impacted by the disclosure. Added to this, ministers who received donations from the Klan began to feel pressure from their congregants to identify their sentiments regarding the Invisible Empire. In one particular example, Rev. William Hovie of the Grand Avenue Temple was warned that if "hooded" meetings continued within the walls of his church, it would be bombed. ${ }^{139}$ Not long after this threat, the National Business Men's Protective Association went forward with plans for a massive event at Convention Hall in downtown Kansas City. ${ }^{140}$ The true identity of the National Business Men's Protective Association only fooled the managers of Convention Hall as a large crowd, estimated at thirty thousand, filled the seats to hear the "business" of Klanism and white supremacy.

The speakers headlining the Klan rally at Convention Hall were a who's who of Kansas City hate peddlers. John R. Jones, a national organizer for the Klan who was currently in a tug-of-war with a few local Klansmen over control of Kansas City, was the main speaker. Joining him on stage was Rev. E.L. Thompson of the Jackson Avenue Church, Rev. J.W. Darby of the Central Christian Church, Glenn Bruner, an independent candidate for Circuit Court Judge, and Billy Parker, editor of the nationally-known antiCatholic newspaper New Menace published in Aurora, Missouri. ${ }^{141}$ While each man generally kept to key Klan talking points such as patriotism and Americanism, Rev. Thompson used his time at the podium to launch into a heated tirade directed at the

\footnotetext{
${ }^{139}$ Kansas City Star, 10 October 1922; Kansas City Journal, 10 October 1922.

${ }^{140}$ Kansas City Star, 10 October 1922; Kansas City Journal, 10 October 1922.

${ }^{141}$ Kansas City Journal, 11 October 1922.
} 
Kansas City Catholic Register. To counter the anti-Klan activities of the Register, Thompson called on his audience to consider boycotting Catholic establishments as a show of the Klan power. ${ }^{142}$

The Klan's reliance on Christian ministers to defend the organization and denounce its enemies is important because of a growing split among Protestant churches over the Invisible Empire. Historian Kelly J. Baker notes that "local churches still proclaimed their affiliation to the Klan despite outcry from national bodies." ${ }^{143}$ Yet, while local Protestant ministers were overwhelmingly targeted and recruited by the Klan, evangelical sects, rather than traditional mainline churches, tended to back the organization. This is not to say, however, that influential mainline ministers did not join, or at least support, the Klan. In small communities across the United States, Klan donations and meetings were just as likely to take place at prominent mainline denominations as they were at evangelical sects because, according to Leonard Moore, "the thrust of its ideology...conformed to views that were prevalent among... white Protestants. ${ }^{.144}$

Perhaps the most significant example of denominational in-fighting over the Klan issue in Missouri can be traced to Rev. Charles McGehee of St. Louis' Haven Street Methodist Church. When not delivering sermons in the pulpit, McGehee traveled throughout Missouri and Illinois giving lectures for the Klan. ${ }^{145}$ The fact that he wore

142 Kansas City Journal, 11 October 1922.

${ }^{143}$ Baker, Gospel According to the Klan, 38.

${ }^{144}$ Moore, Citizen Klansmen, 28.

145 "Minutes of Proceedings of Investigating Committee on Methodist Episcopal Church, South versus Charles D. McGehee," n.d., Folders 68-71, William Fletcher McMurry Papers, State Historical 
Klan robes over his minister's robes did not bother many in St. Louis, but when he began to discuss the hooded order in his sermons, officials of the Methodist Episcopal Church, South, started to object. McGehee's support for the Invisible Empire resulted in frequent clashes with Bishop W.F. McMurry who felt that the Klan should not be "the theme of a sermon within the walls of the Methodist Episcopal Church." ${ }^{146}$ After receiving a warning from Bishop McMurry for "cutting loose" in a sermon attacking the Catholic Church, McGehee arranged to switch pulpits with C.C. Crawford, another St. Louis minister connected to the Klan, for a Sunday service. While Crawford denounced the opponents of the Klan at Haven Street Methodist Church, McGehee told those in the pews at Fourth Christian Church of an "invisible empire of righteousness warring against an invisible empire of evil." ${ }^{147}$

When McGehee took to the local press to defend the actions of the Ku Klux Klan, Bishop McMurry had had enough. He called McGehee into a meeting at the offices of the Church Board of Finance where a heated altercation occurred. McGehee later claimed that McMurry called him a liar before striking him in the face multiple times. McMurry denied the charges and informed the press that the pulpit and the Klan should not be mixed. ${ }^{148}$ "The klan does not suit me," he told reporters, "I could not join because

Society of Missouri, Columbia, Missouri (hereafter cited as WFM, SHS-MO); St. Louis Post-Dispatch, 20 June 1923, 25 June 1923, 24 September 1923.

${ }^{146}$ St. Louis Post-Dispatch, 12 March 1923, 16 April 1923, 25 June 1923, 1 September 1923, 2 September 1923, 3 September 1923.

${ }^{147}$ St. Louis Post-Dispatch, 25 June 1923.

148 "Minutes of Proceedings of Investigating Committee on Methodist Episcopal Church, South versus Charles D. McGehee," n.d., Folders 68-71, WFM, SHS-MO; St. Louis Post-Dispatch, 1 September 1923. 
I am not anti-foreigner, anti-Jew, or anti-negro."149 Since the confrontation involved the bishop, officials from the Methodist Episcopal Church, South decided to hold hearings over the matter. ${ }^{150}$ Seeking vindication, McGehee went to work lobbying fellow ministers, including some allegedly affiliated with the Klan, to take up an official inquiry against McMurry. ${ }^{151}$ As rumors of an investigation swirled, McMurry attacked McGehee's connections to the Klan by pointing out that "I never told Mr. McGehee that I objected to his membership in the Klan...If he wants to parade at night in a mask, that's his business, but I don't believe it will help his work as a minister." McMurry also took the Bible - the very document used by the Klan to defend its existence - and turned it against the Invisible Empire: “Jesus didn’t wear a mask, neither did Paul."152

As McGehee pushed for an inquiry, Bishop McMurry went forward with plans to not reappoint the minister to the Haven Street Church. When McMurry's decision was announced, C.C. Crawford invited McGehee and his congregation to the Fourth Christian Church for a special service in honor of the soon-to-be exiled pastor. At the evening's ceremonies, McGehee made an even more stunning announcement. Citing the altercation with the bishop, McGehee told the crowd that he would not seek a new appointment and would instead become a full-time lecturer for the Ku Klux Klan. Rev. Crawford then presented him with $\$ 750$ as a first paycheck from the Klan. With emotions running high

${ }^{149}$ St. Louis Post-Dispatch, 3 September 1923.

150 "Minutes of Proceedings of Investigating Committee on Methodist Episcopal Church, South versus Charles D. McGehee," n.d., Folders 68-71, WFM, SHS-MO; St. Louis Post-Dispatch, 2 September 1923.

151 "Minutes of Proceedings of Investigating Committee on Methodist Episcopal Church, South versus Charles D. McGehee," n.d., Folders 68-71, WFM, SHS-MO; St. Louis Post-Dispatch, 3 September 1923.

152 St. Louis Post-Dispatch, 1 September 1923, 2 September 1923, 3 September 1923. 
in the tightly-packed church, McGehee declared, to a roar of applause, that "if it comes to a choice between the Methodist Church and the klan [sic], I shall choose the klan [sic]." ${ }^{\prime 53}$ In 1924, the Methodist Episcopal Church, South officially relinquished McGehee's membership and expelled him from the ministry. ${ }^{154}$ This mattered little to the now "Great Titan" of Province No. 1, realm of Illinois. From his office in East St. Louis, McGehee boasted that his current position afforded him a salary equal to those of "two or three of the best-paid ministers of the Methodist Church in St. Louis." 155 By that time, W.F. McMurry was also in a new position as the president of Central College (later Central Methodist University) in the anti-Klan town of Fayette, Missouri. ${ }^{156}$ In addition to the religious overtones of the Klan's activities in 1922, observers also noted the political nature of events like the Convention Hall rally that foreshadowed possible Klan involvement in the November election. ${ }^{157}$ The Kansas City Star

${ }^{153}$ St. Louis Post-Dispatch, 24 September 1923.

154 "Minutes of Proceedings of Investigating Committee on Methodist Episcopal Church, South versus Charles D. McGehee," n.d., Folders 68-71, WFM, SHS-MO; St. Louis Post-Dispatch, 13 February 1924.

${ }^{155}$ St. Louis Post-Dispatch, 13 February 1924.

156 Joplin Globe, 4 June 1924; St. Louis Post-Dispatch, 13 July 1924; St. Joseph Observer, 8 August 1924. In October 1923, Klan recruiter A.L. McKinney arrived in Fayette to give a public lecture at the Howard County Courthouse. After his audience turned out to be quite hostile, McKinney was led out of the town square and taken to a nearby office where he was advised by a group of town leaders to leave Fayette as soon as possible. Given time to collect some personal items from a local hotel, McKinney did just that, though he later claimed that he was shot at and chased by an unknown automobile. Three months after the incident, McKinney filed suit for fifty thousand dollars against seven Fayette residents that cornered him in the office. Citing a possible biased jury, especially after the Fayette Commercial Club voted to support the accused men, McKinney asked that the trial be conducted at Jefferson City in nearby Cole County. The case was eventually dropped. For information on the McKinney incident in Fayette see Fayette Democrat-Leader, 25 October 1923, 24 January 1924, 31 January 1924; Fayette Advertiser, 25 October 1923, 1 November 1923, 24 January 1924, 31 January 1924; St. Louis Post-Dispatch, 25 October 1923; Jefferson City Daily Capital News, 20 January 1924, 13 March 1924, 18 March 1924, 19 March 1924.

${ }^{157}$ Kansas City Star, 11 October 1922; Kansas City Catholic Register, 12 October 1922. 
editorialized that the Klan had sound ideas about the need to establish "good" government, but felt that this did not, and should not, include religious intolerance. Rumors also circulated that the Klan had aligned with the Republican Party in Kansas City to fight the congressional campaign of James Reed as well as the political machines of Tom Pendergast and Joe Shannon. ${ }^{158}$ In addition to plans to topple the Democratic Machines, those who attended Klan rallies in Kansas City heard various speakers attack local issues. Glenn Bruner, who the Register referred to as "a plain week-kneed [sic] opportunist who is trying to ride the waves of anything that will bring him notoriety," used his time at Convention Hall to give a stump speech on behalf of his electoral campaign. ${ }^{159}$ "I believe in the sovereignty of our state rights - in the separation of church and state - in freedom of speech and press, and the maintenance of our free public schools," Bruner told potential voters, "I would give up my life, if need be, to uphold these principles for which I stand.” Billy Parker, no doubt trying to increase subscriptions to the New Menace, appealed to patriotism by reminding the crowd that the Klan "will step down into the valley of the shadow of death and lift Liberty from the muck and mire - placing it on the pedestal where it was mounted by the forefathers of our country." 160

Despite the success of the original Convention Hall meeting, some within the Kansas City Klan felt that the organization would "wither like a rose in autumn" if national recruiters, such as John R. Jones, left the city at the end of 1922. Locally,

\footnotetext{
${ }^{158}$ Kansas City Star, 11 October 1922.

${ }^{159}$ Kansas City Catholic Register, 19 October 1922.

${ }^{160}$ Kansas City Journal, 11 October 1922.
} 
rumors circulated that Jones intended to transfer to a new community to recruit for the Klan. Not all Klansmen, however, shared this sentiment. A fight for control between Jones and local Klansmen had money at its root and it soon began to be circulated that Jones would leave the city with a good portion of the local Klan's treasury. "They [Jones and his associates] will leave Kansas City with thousands of dollars in their pockets," the Register told its readers with a slight hint of sympathy, "contributed by those who were tricked into believing that they ought to wear night shirts at places other than home."161

As the battle for the hearts, minds, and allegiances of local Klansmen raged in Kansas City, the Invisible Empire held another large rally at Convention Hall closer to Election Day. In addition to the collection of speakers from the earlier event, this meeting also featured Gilbert O. Nations, a prominent anti-Catholic speaker from Ohio who was also the father of two prominent Missourians, Gus and Heber Nations. Gus was a Federal Prohibition Agent from St. Louis and one-time member of the Young People's Branch of the Woman's Christian Temperance Union. ${ }^{162}$ Heber had been a newspaper correspondent based in Jefferson City who later served as the State Labor Commissioner under Governor Arthur Hyde. ${ }^{163}$ Though their father was connected to the Klan, the younger Nations had differing stances on the Invisible Empire. Heber would become the Exalted Cyclops of the Jefferson City Klan, while Gus would devote considerable time in his later political career to distancing himself from the sheets in the family closet. ${ }^{164}$

${ }^{161}$ Kansas City Catholic Register, 19 October 1922.

${ }^{162}$ Missouri Counselor, July 1915.

${ }^{163}$ Jefferson City Daily Capital News, 5 January 1921; Jefferson City Democrat-Tribune, 7 May 1924.

164 Jefferson City Tribune, 25 November 1925; St. Louis Argus, 25 July 1924. 
The late October Convention Hall meeting was to be political in nature and antiCatholic in rhetoric. "The speakers were under orders to 'give Casey hell'," the Register said of the Klan's attack on its editor Justin Casey, "and all the venom of many years of hate surged through the mind of Parker and Nations...to sell [their] anti-Catholic medicine to the audience." At one point, in the midst of accusing the Knights of Columbus and students of Rockhurst College, a local Jesuit school, of hiding among the spectators, New Menace publisher Billy Parker challenged prominent local Catholic officials to a debate with a five hundred dollar check going to the person who could make them commit to it. Parker joked that he would join the Catholic Church if he lost the debate. Turning to politics, Parker and others spent time appealing to the crowd to use their votes to dismantle the party machines that dominated the city. ${ }^{165}$ Targeting Joe Shannon, Tom Pendergast, and James Reed, the Klansmen called on the audience of nearly fourteen thousand to sing an alternate version of "Goodby Mule With the Old Hee Haw":

Goodby Tom and Goodby Joe You and Reed will have to go You may not know what it's all about But you bet, by gosh, you'll soon find out;

The town is full of K. K. K. The only thing that they will say, Is goodby Tom and goodby Joe, The crooked gang has got to go ${ }^{166}$

While the earlier meeting had drawn a diverse audience, the Klan initially attempted to exclude women from the second meeting. No doubt influenced by the

\footnotetext{
${ }^{165}$ Kansas City Catholic Register, 2 November 1922.

${ }^{166}$ Kansas City Star, 29 October 1922.
} 
debate raging at the national headquarters in Atlanta over whether women should be allowed to join the Invisible Empire, Klan organizers initially told women to stay home. ${ }^{167}$ Yet, when the meeting convened, women made up roughly half of the audience and they factored prominently as the targets of some Klan speakers. "I know the men made a dirty mess of politics," Billy Parker told the assembled women, "it is up to you...to clean it up...[in] city hall, the school board, and the public schools of the city."168 In fact, at the time of the Convention Hall meeting, prominent Klan officials such as William Simmons, Hiram Evans, and D.C. Stephenson were all formulating plans to establish their own women's Klan auxiliary. ${ }^{169}$

Less than a week after the Klan meeting, and only days before Election Day, Senator James Reed took to the Convention Hall stage to defend his campaign, criticize the policies of "mamma's darling boy" Arthur Hyde, and defeat the Klan. "He gave [the Klan] both barrels at the opening," the Register told its readers, "and when he was through, the hide of the Klan was hanging on a fence, thoroughly cured and scientifically tanned." Reed told the crowd that Klansmen had arrived at the Hall with the sole purpose of disrupting his speech with a mass walk-out. He dared those who "meet behind pillow cases and who wrap themselves in sheets" to start the exodus. No one left. ${ }^{170}$ As Reed

\footnotetext{
167 Kansas City Catholic Register, 26 October 1922.

168 Kansas City Journal, 29 October 1922.

${ }^{169}$ Blee, Women of the Klan, 23-28.

${ }^{170}$ St. Louis Post-Dispatch, 2 November 1922.
} 
worked over the Klan, an audience member urged him on shouting, "beat it now, Kluxer, while the going is good." 171

Reed's anti-Klan rhetoric was not new when he stepped on the Convention Hall stage. In fact, he made attacking the Invisible Empire a cornerstone of his 1922 congressional campaign. It was a political ploy aimed at appealing to his usual white ethnic urban constituents while also garnering favor with those opposed to the Klan, particularly Catholics, Jews, and African Americans that tended to vote Republican. Yet, his prior comments attacking the American Protective Association and later denunciations of Nazism during the 1930s suggest that Reed had a long history of opposition to organized hate, especially in the form of religious animosity. ${ }^{172}$ When he spoke out against intolerance, voter suppression, and "masked" hatred, Reed presented himself as a defender of Missourians from the threats of those who hide behind "pillow sheets." ${ }^{173}$ In doing so, he enhanced his political ambitions and slowly built alliances with a diverse collection of anti-Klan groups that would carry him to victory on Election Day. The Register acknowledged that Reed had always given Catholics a fair deal, even if he was not one of them. ${ }^{174}$ The Jewish Chronicle identified him as "an old friend of the Jewish people." ${ }^{175}$ When the Young Men's Hebrew Association invited him to give a

${ }^{171}$ Kansas City Catholic Register, 2 November 1922.

172 Mitchell, Embattled Democracy, 9-10. It is hard to say when the exact moment was that James A. Reed took up the plight of Jews around the world, but his speech entitled "The Jew," delivered before the Seventh Annual Meeting of the Hebrew Sheltering and Immigrant Aid Society of America, received favorable press in 1915-1916. For resources on Reed's comments on Judaism see Folder 11, Box 41, James Alexander Reed Papers, State Historical Society of Missouri, Kansas City, Missouri.

${ }^{173}$ Kansas City Jewish Chronicle, 26 October 1923; St. Louis Post-Dispatch, 3 April 1924.

${ }^{174}$ Kansas City Catholic Register, 22 June 1922.

${ }^{175}$ Kansas City Jewish Chronicle, 12 August 1921. 
Constitution Day lecture at Temple Shaare Emeth in St. Louis, Reed used the platform to champion the positive impact of Jews in American History while reminding his audience that "any society or group which preaches the doctrines of religious intolerance and race hatreds in the United States is an enemy of constitutional government and should be driven from the country." 176

While Reed may have won support from Catholics and Jews, he had a mixed record when it came to issues important to white feminists and African American voters. Reed had publicly denounced the $19^{\text {th }}$ Amendment and the Sheppard-Towner Act, and his "wet" stance on the issue of Prohibition also made him enemies within the League of Women Voters and the Woman's Christian Temperance Union. ${ }^{177}$ In the eyes of many African Americans, Reed was comparable to Ben Tillman and James Vardaman. The Kansas City Call argued that his "record of hate" showed that "no man in public life outside the black belt of the South...has gone as far as he to prove his unvarying opposition to the race." ${ }^{\prime 178}$ Most objectionable was his opposition to the Dyer AntiLynching Bill. Reed was not against a law to hold members of lynch mobs accountable for their actions, but he favored a state law on such matters over a federal law. ${ }^{179}$ Despite a meeting with members of the NAACP, and pressure from the African American press,

${ }^{176}$ St. Louis Post-Dispatch, 18 September 1922; Jewish Voice, 22 September 1922.

177 Mitchell, Embattled Democracy, 53; Mitchell, "The Re-Election of the Irreconcilable James A. Reed," 426-428; Missouri Counselor, June 1922, September 1922; Union Signal, 1 June 1922, 16 November 1922; Kansas City Journal, 3 June 1922, 14 June 1922.

178 Kansas City Call, 27 October 1922; Ben Tillman and James Vardaman were United States Senators, from South Carolina and Mississippi respectively, who championed white supremacy.

179 Kansas City Journal, 13 October 1922; St. Louis Argus, 24 March 1922; Kansas City Call, 18 February 1922, 1 April 1922, 19 August 1922, 
Reed did not budge from his position on lynching. ${ }^{180}$ As for the Invisible Empire, the Kansas City Call questioned Reed's motivation for fighting the Klan. "He wants us to believe that only one devil can exist at one time and if it is the Klan then it is not Reed," the Call warned its readers, "he forgets that we remember his past."181

Reed's strong anti-Klan stance also allowed him the opportunity to suggest that Republicans, particularly R.R. Brewster and Governor Hyde, were secretly tied to the Invisible Empire. ${ }^{182}$ Though Hyde had come out with an anti-Klan statement in 1921, Reed repeatedly called on the governor to make his true feelings on the Klan known. Having little to hide in the matter, Hyde was more than happy to remind voters that he was anti-Klan. ${ }^{183}$ Turning to his congressional opponent, Reed called upon potential voters to support him to counterbalance the Klan mobilization that was supposedly backing R.R. Brewster. ${ }^{184}$ In response, Brewster reiterated his anti-Klan stance on the campaign trail reminding those in the audience that the Klan "is not for me and I'm not for them."185 At Lexington, Brewster hit back at Reed's accusations by suggesting that Reed would have probably joined the Klan if he were not a politician because he had done little in office to help African Americans. ${ }^{186}$ Despite Brewster's appeal to anti-Klan

${ }^{180}$ Kansas City Call, 18 February 1922, 27 October 1922; St. Louis Argus, 31 March 1922.

${ }^{181}$ Kansas City Call, 27 October 1922.

182 Jefferson City Daily Capital News, 2 November 1922, 3 November 1922; Joplin Globe, 3 November 1922; St. Louis Post-Dispatch, 3 November 1922.

${ }^{183}$ St. Louis Post-Dispatch, 4 November 1922.

${ }^{184}$ Kansas City Journal, 13 October 1922.

185 Joplin Globe, 14 October 1922.

${ }^{186}$ St. Louis Post-Dispatch, 24 October 1922. 
voters, such tactics had little impact on the Reed campaign. The hooded order opposed Reed and favored Brewster, even with his anti-Klan sentiments, as the lesser of two evils. ${ }^{187}$ Reed won re-election in November largely based upon his popularity among Missouri voters, both urban and rural, regarding his opposition to Prohibition. ${ }^{188}$ However, his anti-Klan stance, though not as strong of a political factor as it would be in 1924, also contributed to Reed's victory.

As the votes were tallied, it soon became apparent that rallies, donations, and intimidation had done little to sway the voters of Missouri to the Invisible Empire. In Kansas City, the Democratic Party reaped the benefit of accusations of Klan-Republican ties as many voters rejected the hooded order at the ballot box. In the end, the Klan had been repudiated, but the Register still noted the large number of votes cast in defeat for candidates like Glen Bruner that left "an odor arising from the name of our fair city that makes the stench of a polecat as the famous attar of roses." But, the Register did not stop there with its post-election critique of Bruner:

Glen Bruner has no ability, no character, nothing in his entire makeup that would appeal to any one. On the contrary he is an egotist of the first water, the type of fellow who really believes that his good looks are deadly to the female of the specie and that it is his bounden duty to see that the said females do not lack the beneficent sunshine of his vamping disposition. He was begat from a sire and dam who were bred in the bone bigots and he was reared in that same atmosphere of intolerance and selfishness. He could not be fair to even his children in spite of the fact that he loves them better than his own life, he would take from them the God-given care of their own

\footnotetext{
187 St. Louis Post-Dispatch, 8 November 1922; New York Times, 10 December 1922.

188 Mitchell, Embattled Democracy, 60-61.
} 
mother if he could. Glen Bruner is everything that a good citizen shouldn't be. ${ }^{189}$

There may have been "twenty thousand other Glen Bruners in Kansas City," but the Register felt that the Klan had grown sick and weak in the aftermath of the election. Rumors circulated that the Klan cancelled a parade in the city after the election results confirmed its defeat. By mid-November, after thanking members of the clergy and local citizens for aiding in the expensive fight against the Invisible Empire, the Register boldly declared the Klan dead in Kansas City. But, the Register promised to remain vigilant lest the Klan should "revive sufficiently to again become active." 190 To celebrate the demise of the Klan in the election and conclude its campaign against the Invisible Empire, the Register mocked the hooded order with “An Ode to Jones, DeNise \& Co.”:

Goodbye Tom, Goodbye Joe Me and the Klan will have to go, You beat us so bad we've got to get out. And believe me b'gosh [sic] it was an awful clout The town seemed full of K. K. K. But the darned old votes didn't count that So it's goodbye Tom, and goodbye Joe Us crooked guys has got to go ${ }^{191}$

While the re-election campaign of James Reed had galvanized anti-Klan sentiment across the state, the mayoral race in Joplin, won by businessman Taylor Snapp,

${ }^{189}$ Kansas City Catholic Register, 9 November 1922.

190 Kansas City Catholic Register, 9 November 1922, 16 November 1922. Though it declared the Klan dead and vowed not to fight "dead ones" and "cripples," the Register did continue to publish articles about Klan activity around the United States for the rest of 1922, Kansas City Catholic Register, 23 November 1922, 30 November 1922, 7 December 1922, 14 December 1922, 21 December 1922, 28 December 1922.

${ }^{191}$ Kansas City Catholic Register, 9 November 1922. 
served as a barometer of hooded strength in southwest Missouri. ${ }^{192}$ Though he did not actively solicit Klan support during his mayoral campaign, critics later claimed that Snapp's victory over Charles Patterson in 1922 ushered in a period of close alliance between city hall and the local klavern. ${ }^{193}$ With few Klan documents surviving from the county, it is hard to prove that a victory for Snapp was a victory for the Invisible Empire. However, when given the opportunity, Snapp did not distance himself from the Klan. It was Snapp who approved plans for a Klan parade through Joplin to honor visiting Imperial Wizard Hiram Evans. ${ }^{194}$ Snapp was also in attendance at Joplin's First Congregational Church when Klansmen arrived to give a donation. ${ }^{195}$ Finally, and perhaps most damning, Snapp was reportedly seen meeting in secret with local Exalted Cyclops Pierre Wallace on at least one occasion. ${ }^{196}$

He may have won the mayor's seat over Patterson without overt hooded support, but Taylor Snapp's victory stirred strong anti-Klan feelings in Jasper County. In a letter to Missouri Secretary of State Charles Becker, one Jasper County resident warned that "sentiment [regarding the Klan] seems to be equally devided [sic] and some Citizens and [sic] arming themselves as a defense of their homes and property, if relief is not furnished in time a clash is inevitable resulting in much bloodshed."197 Such forebodings worried

192 Joplin Globe, 5 April 1922.

193 Joplin Globe, 6 April 1926, 7 April 1926, 3 July 1926.

194 Joplin Globe, 5 August 1923.

195 Joplin Globe, 23 February 1923.

196 Joplin Globe, 6 April 1926.

197 P.W. Burden to Charles Becker, 14 December 1922, Folder 366, AMH, SHS-MO; Charles Becker to P.W. Burden, 16 December 1922, Folder 366, AMH, SHS-MO. 
Governor Hyde and he personally wrote to the resident expressing hope that legislation in the upcoming year would give more power to state and local authorities to deal with issues involving the Klan. ${ }^{198}$ The prediction of an inevitable clash in Jasper County over the Klan eventually came true, but it was more a war of words than of bloodshed.

In Jasper County, a fight over the Ku Klux Klan had been growing behind the scenes for most of 1921 and 1922. The Klan had reached considerable size in Joplin, Carthage, Webb City, and Cartersville by the start of 1923, but opposition, which had been largely non-existent initially, began to mount. This anti-Klan sentiment came alive at a retirement banquet for Judge J.D. Perkins. As one of the principal speakers at the event, Frank Forlow, a Webb City resident and president of the Jasper County Bar Association, used his time at the podium to call out the Ku Klux Klan as unconstitutional. ${ }^{199}$ While Forlow's words may have seemed out of place at a banquet honoring a retiring civic official, others in Jasper County shared his feelings on the Klan. Less than a week after his statements, the Jasper County Bar Association announced that it would hold a meeting to gauge the general opinion of its members towards the Klan. ${ }^{200}$

The decision by a Bar Association to examine the "Klan" question was not new in southwest Missouri. In November 1922, the Bar Association of the city of Springfield decided to ban all members who were associated with the Klan. ${ }^{201}$ Following Springfield's lead, the Jasper County Bar Association moved to take similar action. At

\footnotetext{
${ }^{198}$ Arthur Hyde to P.W. Burden, 27 December 1922, Folder 366, AMH, SHS-MO.

199 Joplin Globe, 12 January 1923.

200 Joplin Globe, 18 January 1923.

201 Joplin Globe, 18 November 1922.
} 
its meeting, the Bar Association issued a public denouncement of the Klan and also pursued action to remove Klansmen from the organization. Additionally, its members called on the state legislature to pass laws that would outlaw the Invisible Empire in Missouri. No one, at least within the confines of the meeting, spoke favorably of the Klan. Instead, according to the Joplin Globe, the Klan was condemned as a "menace to government." Among those who took the opportunity to address the Bar Association on their opposition to the Klan were local attorneys Allen McReynolds, Howard Gray, and George Grayston. ${ }^{202}$ The involvement of McReynolds, Gray, and Grayston in the Bar Association's anti-Klan fight inspired them to pursue similar action in their own communities. Not long after the initial meeting, all three men moved to establish antiKlan groups throughout Jasper County. As will be discussed in more detail in Chapters 5 and 6, McReynolds, Gray, and Grayston became the driving force behind the Joplin AntiKlan Organization, Carthage Anti-Klan Association, and Jasper County Anti-Klan Association.

The Bar Association's denouncement as well as the public anti-Klan sentiments expressed by men like McReynolds, Gray, and Grayston angered the Invisible Empire of Jasper County. Two days after the Bar Association meeting, Ozark Klan No. 3 issued a lengthy advertisement in the Joplin Globe detailing the Klan's record in favor of patriotism and efficient law enforcement. ${ }^{203}$ While this initial advertisement was ambiguous in its target, a second one, issued on January $25^{\text {th }}$, took direct aim at the Bar Association. Suggesting that some of the men that signed the anti-Klan resolution got

\footnotetext{
202 Joplin Globe, 21 January 1923.

203 Joplin Globe, 23 January 1923.
} 
their civic positions through party loyalty instead of public record, the Klan, according to the letter, noted that it had:

...sought no fight in this community which is ours, as well as yours. The KU KLUX KLAN is founded on principles of Right and Justice, which principles are the foundation of civilized government and existed long before the bar of justice was graced by your presence, and which principles will endure long after the disgruntled, and dissatisfied, and hard-to-die politicians, and intolerant squealers of intolerance among you have dropped by the wayside. While the best things your Association has ever been known to do is to pass resolutions and makes speeches, the KU KLUX KLAN in Jasper County is, and has been since its organization, unceasing in its work for the betterment and advancement of the interests of ALL CITIZENS, and while your members seem very anxious that we "come out in the open," we assure you that no one, whose conscience is clear and whose conduct is above reproach, need have any fear of our "invisibility." 204

After the Klan's scathing comments in the Joplin Globe, the Jasper County Bar Association reconvened to again discuss the hooded order. This time, the anti-Klan sentiment was not unanimous. Local attorneys Ray Bond, Grover C. James, and John B. Cole all came forward to voice their opposition to the original resolution. Claiming they were not Klansmen, each man cited that the information collected on the local Klan was based on hearsay and, thus, not reliable for issuing a resolution. The nearly four hour meeting was also muddied by a list that was circulated containing the names of suspected local Klansmen. As the list contained the names of some Bar Association members, including Roy Coyne, who had spoken out against the Klan at the first meeting, its validity was questioned by those in attendance. One who did not question his name being

204 Joplin Globe, 25 January 1923. 
on the list was Jasper County Sheriff Harry Mead who admitted that he had joined the Klan at one time but had left near the end of $1922 .{ }^{205}$

In addition to discussing the Klan as a "menace to government," Jasper County residents also questioned the religiosity of the Invisible Empire. At a Presbytery meeting in Carthage, W.R. Robertson, James D. McCaughtry, and R. Howard Augustine pushed for a resolution denouncing the Klan. After a lively debate and strong opposition from Rev. Robert Nicholson of Golden City and Rev. John Stapleton of Sarcoxie, the resolution was tabled. ${ }^{206}$ Similar to their brethren in Joplin, Paul Revere Klan No. 13, based in Carthage, took to the press to defend the "Christian Organization" against such attacks. According to the Carthage Klansmen, the Klan held "as its Great Exemplar and First Klansman, Jesus of Nazareth, the Christ" and was "glorified and honored as upholders of the Law and Constitution, as defenders of the Flag, as bearers of the Fiery Cross, to be set upon by the descendants of those who persecuted and hung the Great Master upon the Tree." 207

If its opponents were going to accuse the Klan of ties to un-American and unChristian activities, the hooded knights were going to tie themselves tightly to the ideals of law and order. This opportunity presented itself when Governor Arthur Hyde issued a "law and order" proclamation in January 1923. In an attempt to increase public support for Prohibition and law enforcement, as well as offer a rebuke of extralegal vigilantism, Governor Hyde called on "all civic and religious organizations, and upon the citizenship

\footnotetext{
205 Joplin Globe, 28 January 1923.

206 Joplin Globe, 25 January 1923.

207 Joplin Globe, 26 January 1923.
} 
generally to give thought and consideration upon the safeguards of our liberties as embodied in the Constitution and laws of our state and nation." Issued on January 18, 1923, Hyde's proclamation declared that the last Sunday of the month would be "Law and Order Sunday."208 While Hyde received a fair amount of support for his proclamation from members of the law enforcement community, his biggest endorsement came from the Invisible Empire. ${ }^{209}$ From all corners of the state, letters and telegrams began to arrive in Jefferson City with the signature and seal of the Ku Klux Klan. All told, Hyde received correspondence from twenty-five Missouri Klan chapters. Most of these correspondences commended the governor for his stance on law enforcement and informed him that the Klan would "go on record at this time as against mob violence and unconstitutional methods of procedure by any individual, set of individuals, organization or organizations." 210

In writing to the governor, these Klansmen hoped to show their loyalty to law enforcement as well as demonstrate the unified strength of Missouri's Invisible Empire. What can also be found in these correspondences is a number of key pieces of information about the geographic growth of the Klan within the state. First, a letter from

${ }^{208}$ Law and Order Sunday Proclamation, Arthur Hyde, 18 January 1923, Folder 511, AMH, SHSMO.

${ }^{209}$ Columbia Missourian, 27 January 1923.

${ }^{210}$ Wallace Klan \#60 to Arthur Hyde, 25 January 1923, Folder 367, AMH, SHS-MO; Willow Springs Klan Number Thirty Five Realm of MO to Arthur Hyde, Western Union Telegram, 26 January 1923, AMH, SHS-MO; W.M. Campbell to Arthur Hyde, Western Union Telegram, 27 January 1923, AMH, SHS-MO; John E. Slater to Arthur Hyde, Western Union Telegram, 28 January 1923, AMH, SHS-MO; Isaac Shambaugh Klan \#7 Neosho, Granby Provisional Klan, Diamond Provisional Klan to Arthur Hyde, Western Union Telegram, AMH, SHS-MO; Higginsville Klan No. 36 to Arthur Hyde, 27 January 1923, AMH, SHS-MO; Washburn Klan No. 25 to Arthur Hyde, 23 January 1923, AMH, SHS-MO; Holden Klan No. 30 to Arthur Hyde, N.D., AMH, SHS-MO; Independence Klan No. 27 to Arthur Hyde, 27 January 1923, AMH, SHS-MO; Pleasant Hill Klan No. 54 to Arthur Hyde, 28 January 1923, AMH, SHS-MO. 
Wallace Klan No. 60 indicates that by the beginning of 1923 there were at least sixty

Klan chapters in the state. While in most cases this incorporation number is an accurate representation of total chapters, it can also be misleading. This is evident in the Klan's communication with Hyde as Springfield's number is 1211 and Twin City is listed as 493. If the other chapter numbers are interpreted as accurate, then the Missouri Klan had grown exponentially since the founding of Joplin's Ozark Klan No. 3 in 1921.

Second, the locations of the various Klan chapters indicate a steady growth by the organization out of its original border recruitment points. In southwest Missouri, Joplin's Ozark Klan No. 3 was soon accompanied by klaverns in Neosho, Aurora, Springfield, Marshfield, Washburn, Granby, and Diamond. ${ }^{211}$ Moving along the Missouri/Arkansas border, chapters were also established in Willow Springs, Kosh Konong, Naylor, and Malden. ${ }^{212}$ On the outskirts of Kansas City, the Klan soon appealed to the residents of Adrian, Odessa, Higginsville, Holden, Pleasant Hill, and the "1205 of Jackson Counties best men" living in Independence. ${ }^{213}$ But, more than any other region of Missouri, the northwestern part of the state went through an intense "kluxing" in the early 1920 s.

${ }^{211}$ Isaac Shambaugh Klan \#7 Neosho, Granby Provisional Klan, Diamond Provisional Klan to Arthur Hyde, Western Union Telegram, AMH, SHS-MO; Washburn Klan No. 25 to Arthur Hyde, 23 January 1923, AMH, SHS-MO; Willow Springs Klan Number Thirty Five Realm of MO to Arthur Hyde, Western Union Telegram, 26 January 1923, AMH, SHS-MO.

212 Willow Springs Klan Number Thirty Five Realm of MO to Arthur Hyde, Western Union Telegram, 26 January 1923, AMH, SHS-MO.

213 Willow Springs Klan Number Thirty Five Realm of MO to Arthur Hyde, Western Union Telegram, 26 January 1923, AMH, SHS-MO; Higginsville Klan No. 36 to Arthur Hyde, 27 January 1923, AMH, SHS-MO; Holden Klan No. 30 to Arthur Hyde, N.D., AMH, SHS-MO; Independence Klan No. 27 to Arthur Hyde, 27 January 1923, AMH, SHS-MO; Pleasant Hill Klan No. 54 to Arthur Hyde, 28 January 1923, AMH, SHSMO. 
Beginning with St. Joseph Klan No. 4, the region also held Klan chapters in Wallace, Trenton, Fairfax, Agency, Gower, and Holt County. ${ }^{214}$

With the growth of groups like the Knights of Columbus, NAACP, American Unity League, and B'nai B'rith in the state, along with the continued outspoken activism of politicians, religious officials, and the press, it would appear that J.F. Craig's words were true and that the Klan really was "catching hell from all quarters" in Missouri by early 1923. Yet despite calls for an obituary to the hooded organization by the Kansas City Catholic Register, the Klan was very much alive following the 1922 Election.

Klansmen had been sent home to lick their wounds after a stinging defeat, but this did not mean that they hung their robes in the closet, never to be donned again. Instead, the Klan took its lumps in 1922 and learned a valuable lesson. To survive and thrive, it needed to recruit more members from new parts of the state. Rural Missouri, not urban Missouri, offered the best hope for growing the Invisible Empire. Additionally, it needed to hold sway among the political parties of the state. If incumbent candidates rebuked the order, then an insurgency would be the new route. The Klan moved to address both of these issues in 1923 and 1924, but claims of vigilantism and violence constantly hung over the head of Klansmen (and newly affiliated Klanswomen) as they reached out to new members through the pulpit, the pews, and the polls.

${ }^{214}$ W.M. Campbell to Arthur Hyde, Western Union Telegram, 27 January 1923, AMH, SHS-MO; John E. Slater to Arthur Hyde, Western Union Telegram, 28 January 1923, AMH, SHS-MO; Wallace Klan \#60 to Arthur Hyde, 25 January 1923, AMH, SHS-MO; Willow Springs Klan Number Thirty Five Realm of MO to Arthur Hyde, Western Union Telegram, 26 January 1923, AMH, SHS-MO. 


\section{Chapter 4: "The Eyes of the Nation are upon Missouri"}

In spring 1923, H.S. Ahrens frantically traveled throughout southeast Missouri. What had once seemed like a prime location for a membership sales pitch had recently turned into a war zone. The thaw of winter brought anticipation of an agricultural boom year, but it also led to an outbreak of racial violence. Reports of shots fired at African American homes and warnings to leave the area caused panic throughout the region. Railroad officials and local residents estimated that over 200 African Americans, many of them agricultural laborers, fled the Cotton Belt. Not wanting local residents to assume that his organization, the Ku Klux Klan, was responsible for the increased vigilantism, Ahrens scoured most of the Cotton Belt denouncing the violence. He felt it necessary to make the trek because some of the intimidating letters sent to local blacks had been signed “K.K.K." In Pemiscot County, Ahrens distributed over one thousand handbills offering a hefty reward for information about the guilty parties. He also told the press that "with the better class of citizens in the county, members of the Klan recognized that negroes were necessary to cultivate and pick cotton crops." As such, the Klan was "not participating in anything to disturb the peace of mind of the negroes." ${ }^{1}$ When told of local concerns regarding recent Klan activity, particularly his own recruitment in the region, Ahrens expressed hope that the organization's actions in stemming the violence would "allay the fear."

\footnotetext{
${ }^{1}$ St. Louis Post-Dispatch, 4 March 1923.

${ }^{2}$ St. Louis Post-Dispatch, 4 March 1923; Caruthersville Democrat-Argus, 23 February 1923, 27 February 1923.
} 
At the time of H.S. Ahrens journey through southeast Missouri, the Ku Klux Klan was in a period of serious transition. Having wrested control of the organization away from William Simmons during a coup d'état at the 1922 Klan Klonvokation, the newly appointed Imperial Wizard, Hiram Evans, had big plans for the organization. ${ }^{3}$ First, Evans, along with other Klan officials, examined the recruiting possibilities connected to opening membership to white women. In offering the robe and hood to women, the Invisible Empire grew in membership; but such a decision increased tensions between Klan leaders, local klaverns, and newly formed auxiliary organizations. Second, Evans intended to mobilize local klaverns into politically active groups. While Klansmen, and newly incorporated Klanswomen, realized that the organization lacked the power to be a prominent third party, hooded officials felt confident that they could build strong alliances with influential political entities in certain localities. Finally, Evans, though a one-time member of the Dallas Klan's terror squad, hoped that the organization's involvement in more respectable venues like politics and women's recruitment would separate the hooded order from claims of vigilantism and violence.

Despite past incidents of hooded vigilantism, the Ku Klux Klan tried to distance itself from accusations of violence under the leadership of Imperial Wizard Hiram Evans as a means to build a politically motivated organization cloaked in respectability. However, though the Klan attempted to cut ties with its night-riding past, old habits died hard in the Invisible Empire and the hooded order took the blame in prominent cases of vigilantism. Added to this, the general perception - largely cultivated by the anti-Klan

\footnotetext{
${ }^{3}$ Chalmers, Hooded Americanism, 98-108; Jenkins, Steel Valley Klan, 6-9; Alexander, The Ku Klux Klan in the Southwest, 109-110; Lay, The Invisible Empire in the West, 8-9; Blee, Women of the Klan, 23-27.
} 
press - that the organization was violent, hurt recruitment. This was especially true in Missouri. As the state Klan spread out into new recruiting territory beyond its established klaverns, Missouri underwent a series of violent events that concerned state residents. Writing to Governor Arthur Hyde, NAACP Executive Secretary James Weldon Johnson warned that the "eyes of the nation are upon Missouri."4 Hyde understood this point well as he spent substantial time during his administration trying to investigate multiple lynchings, deploy National Guard detachments to prevent anti-black violence, and address a series of home bombings in the state's urban centers. Yet, just as Hyde was attempting to quell these concerns, so too did the Missouri Klan fight to shed the image that it was responsible for these acts of violence. Ultimately, though some within the state's hooded order were successful in building a reputation as law and order reformers, the Missouri Klan as a whole experienced difficulty in growing the organization due to its inability to separate itself from allegations of violence and vigilantism.

Not long after assuming control of the Klan, Hiram Evans embarked on a tour of his Invisible Empire. Evans visited Missouri, and places throughout the United States, to assert his control over the organization and show Klansmen in far-flung klaverns that he was in charge. Such a move was necessary after William Simmons' decision to start a rival Klan-like organization geared towards women following his ouster as Imperial Wizard. Klan officials had initiated discussions about incorporating women into the

\footnotetext{
${ }^{4}$ James Weldon Johnson to Arthur Hyde, 30 April 1923, Western Union Telegram, Folder 107,
} AMH, SHS-MO. 
hooded order due to their involvement in suffrage, temperance, and various reform movements, but these conversations went slow at first and Evans even issued a proclamation forbidding Klansmen from lending aid in the creation of any women's auxiliary. ${ }^{5}$ Yet, as sociologist Kathleen Blee has noted, women wrote to Klan publications frequently during the early 1920s to make the case that their patriotism and devotion to the cause of Americanism earned them a place in the Invisible Empire. ${ }^{6}$

Klan leaders like Evans, Simmons, and Indiana Grand Dragon D.C. Stephenson heard the claims made by women for their inclusion, and pushed for female membership as a way to build their own power within the organization's hierarchy. With Evans in charge of the Klan, and hooded officials dragging their feet on the logistics of female membership, Stephenson and Simmons saw an opening. Three months before the official organization of the Women of the Ku Klux Klan, Simmons established his rival Kamelia. Stephenson followed with the Indiana-based Queens of the Golden Mask. ${ }^{7}$ The Women of the Ku Klux Klan was officially chartered on June 10, 1923, with its main headquarters initially located at Little Rock, Arkansas. ${ }^{8}$ Membership in the WKKK was open to "white Gentile female native-born citizens over eighteen years of age who owed no allegiance to any foreign government or sect...[and] who were not Catholic, Socialist,

\footnotetext{
${ }^{5}$ Blee, Women of the Klan, 23-28; Missouri Valley Independent, 5 April 1923, 19 April 1923; The Imperial Night-Hawk, 4 April 1923.

${ }^{6}$ Blee, Women of the Klan, 23-28.

${ }^{7}$ Blee, Women of the Klan, 23-28.

${ }^{8}$ Blee, Women of the Klan, 26-28; Baker, Gospel According to the Klan, 135-138; Kenneth Barnes, Anti-Catholicism in Arkansas: How Politicians, the Press, the Klan, and Religious Leaders Imagined an Enemy, 1910-1960 (Fayetteville: University of Arkansas Press, 2016), 122-123.
} 
Communist, or so forth."9 With annual dues set at ten dollars, the WKKK replicated the Klan in many ways, including an agenda based on nativism, racism, and xenophobia couched as Americanism. ${ }^{10}$ Yet, as the Imperial Night-Hawk clearly laid out, it was to be an organization "composed entirely of women... [and] operated exclusively by women for women." 11

Headed initially by Arkansas native Lulu Markwell, and later Robbie Gill Comer, the WKKK pushed for political and social reforms such as public education, Americanization programs, censorship of public amusements, child welfare legislation, and effective Prohibition enforcement. ${ }^{12}$ The organization also moved quickly to bring in the wives, mothers, sisters, and daughters of Klansmen as well as women previously unattached to the Klan in an effort to consolidate the number of Protestant women's clubs that preached One Hundred Percent Americanism. ${ }^{13}$ The WKKK did this by appealing to

${ }^{9}$ Blee, Women of the Klan, 28.

${ }^{10}$ Blee, Women of the Klan, 28, 34-35, 39-40.

11 The Imperial Night-Hawk, 1 August 1923.

12 Blee, Women of the Klan, 28-60; Baker, Gospel According to the Klan, 125-161; Barnes, AntiCatholicism in Arkansas, 122-124; Chalmers, Hooded Americanism, 57-58, 240-241.

${ }^{13}$ Blee, Women of the Klan, 25-26. One of the most prominent organizations that the WKKK attempted to draw members from was the Woman's Christian Temperance Union. The link between the WCTU and WKKK, however, was a tenuous one. Though historians such as Ruth Bordin and Ian Tyrrell have documented examples of nativism, bigotry, and racism within the WCTU, particularly in the push by some members for stricter immigration laws, de jure segregation, a prohibition on office-holding for nonProtestants, and mandatory English language education in public schools, scholars have also noted how the organization's “Do Everything" policy embraced diversity, ecumenicism, and interracial cooperation. While some of its members did become Klanswomen, particularly Imperial Commander Lulu Markwell, the WCTU gave little indication about its own feelings on the Klan. During the entire 1920s, the WCTU's official publication, Union Signal, only discussed the Klan once. Additionally, it is unknown if any national WCTU officials expressed outward support or condemnation for members joining the WKKK. The same could be said for the Missouri WCTU. The Missouri Counselor, the state organization's publication, never mentioned the Klan in its pages and gave only a vague reference to "One Hundred Percent Americanism." However, the Missouri Cash-Book, an unofficial WCTU newspaper, did offer a clear denouncement of the Klan when it declared that "[w]e are not a defender of the K.K.K. organization because no organized body that stands for patriotism, 100 per cent Americanism, free speech and a free press ought to get behind a 
the political activism of post-suffrage women, while also embracing the tenets of traditional values and home protection that the Klan trumpeted. ${ }^{14}$ At its height, the WKKK had a total membership of roughly $250,000-500,000$ spread out over thirty-six states. $^{15}$

Though it predated the creation of the organization by a few months, one of the biggest contributing factors to the growth of the WKKK in Missouri was the 1922 killing of Nellie Hale, a white teenager from St. Joseph. "It all happened so quickly that it seemed only a minute before it was all over," an eyewitness told the St. Joseph NewsPress of the young girl's death. ${ }^{16}$ Hale, who had been out for an automobile ride with her brothers, was accidently shot by police on the outskirts of St. Joseph. The local police department initially denied their involvement in her death arguing instead that the bullet removed from Nellie's body came from a suspected bootlegger. The Hale family, however, felt that reckless shooting by the police had inflicted the mortal wound. ${ }^{17}$ This

mask or seek the cover of darkness to teach or instill these principles." For more information on the WCTU and its stance on issues of bigotry see Ruth Bordin, Woman and Temperance: The Quest for Power and Liberty, 1873-1900 (Philadelphia: Temple University Press, 1981), 85-87; lan Tyrrell, Woman's World, Woman's Empire: The Woman's Christian Temperance Union in International Perspective, 1880-1930 (Chapel Hill: University of North Carolina Press, 1991), 4-8, 81-113; Ruth Bordin, Frances Willard: A Biography (Chapel Hill: University of North Carolina Press, 1986), 54-65; Glenda Elizabeth Gilmore, Gender and Jim Crow: Women and the Politics of White Supremacy in North Carolina, 1896-1920 (Chapel Hill: University of North Carolina Press, 1996), 45-59; Lisa McGirr, The War on Alcohol: Prohibition and the Rise of the American State (New York: W.W. Norton \& Company, 2016), 139-142; MacLean, Behind the Mask of Chivalry, 40, 106, 110, 116; Blee, Women of the Klan, 25-28, 40, 103-104; Union Signal, 22 May 1924; Missouri Counselor, December 1922; St. Louis Post-Dispatch, 9 September 1925, 10 September 1925, 14 September 1925; Missouri Cash-Book, 20 September 1923.

\footnotetext{
${ }^{14}$ Blee, Women of the Klan, 52-56; Baker, Gospel According to the Klan, 125-161.

${ }^{15}$ Blee, Women of the Klan, 29-30.

${ }^{16}$ St. Joseph News-Press, 20 October 1922.

17 St. Joseph News-Press, 20 October 1922.
} 
assumption was soon verified when witness testimony, physical evidence, and the identities of those in the "bootlegging" car were revealed in the days after Hale's death. ${ }^{18}$

With evidence mounting against the police department, the three-member police commission concluded that officers had falsely assumed that the vehicle they pursued contained bootleggers and that they fired in the direction of the automobile with no provocation. Instead of hitting its intended, if incorrect, target, the bullet struck Nellie Hale, "an entirely innocent person."19 Acknowledging public outrage over the killing and concerns voiced by citizens over recent, questionable activity tied to the police force, the commission moved quickly to hold those responsible accountable. Two of the three officers involved in the shooting were immediately dismissed from the police department. $^{20}$ Another officer who was under investigation following the shooting death of a St. Joseph resident a few weeks earlier also resigned. ${ }^{21}$ But, commissioners voiced caution in the face of public pressure regarding Chief of Police Clay McDonald because they felt that any quick decisions on his status might be interpreted as bowing to external forces, particularly the local Ku Klux Klan. Though, Commissioner Walter Fulkerson

\footnotetext{
${ }^{18}$ St. Joseph News-Press, 20 October 1922, 21 October 1922. John Bond and Verna Nye came forward as the occupants of the automobile being followed by police for suspected bootlegging activities, though no evidence was found to suggest they were law violators.

${ }^{19}$ St. Joseph News-Press, 20 October 1922, 21 October 1922.

${ }^{20}$ St. Joseph News-Press, 20, October 1922, 21 October 1922, 23 October 1922.

${ }^{21}$ St. Joseph News-Press, 23 October 1922; George Wells shot Carl Schimpfesser following a disturbance at a local pool hall. Though witnesses said Schimpfesser was not involved in the fight, police decided to take him in for questioning and he was shot when he allegedly tried to flee the officers. The St. Joseph Observer noted that "it has become an almost frequent occurrence for a police officer to kill someone," St. Joseph Observer, 30 September 1922.
} 
did admit that "Catholics, Protestants, Jews and negroes - all classes are against the chief." 22

In the aftermath of Nellie Hale's death, St. Joseph Klan No. 4 moved quickly to cloak itself in robes of respectability, reform, and non-violence. The organization announced its intention to participate in Hale's funeral and scheduled a public forum at Smith Park to discuss law enforcement and public safety. With McDonald's head on the chopping block and members of the police force resigning, the Klan used its Smith Park meeting to pressure the police commission. Speakers, including Exalted Cyclops William M. Campbell, called on the commissioners to hold the police department accountable - or to resign themselves. If commissioners did not meet this request, the Klan was prepared to circulate a petition asking Governor Arthur Hyde to remove them. Reminding those in attendance of the death of little Nellie Hale at the hands of an ineffective and oppressive police force, the speakers painted a bleak picture of life in St. Joseph: "It is getting to be so bad in St. Joseph that we are afraid to go out riding in our automobiles with our women and children in the country, or even go to our parks or out in our front yards for fear of being struck by a stray bullet fired by a member of the police department."23 While evidence certainly indicates that local police, including Chief of Police McDonald, attempted to pressure the coroner's office into corroborating their version of the "bootlegger" story, the Ku Klux Klan's involvement in the controversy transcended the issue of corruption. ${ }^{24}$ Clay McDonald, the focal point in the investigation, was well

\footnotetext{
${ }^{22}$ St. Joseph News-Press, 21 October 1922.

${ }^{23}$ St. Joseph News-Press, 23 October 1922.

${ }^{24}$ St. Joseph News-Press, 21 October 1922
} 
known to the local Klan. It had been McDonald who only a year earlier had shut down a series of recruitment meetings organized by local Klansmen. McDonald's efforts had initially received support from many local officials because of his anti-Klan stance. ${ }^{25}$ Now, however, the roles were reversed. McDonald was denounced and the Klan appeared as the hero - ever-ready to pressure the governor into disbanding the police commission in the name of law and order. As the St. Joseph Observer noted, "[the police department's] punishment which will follow will be brought about principally by the good work of the local Ku Klux Klan which through a monster mass meeting and law enforcement promptings forced the officials to adopt prompt and vigorous measures to punish the law breakers." 26

In addition to its public comments during the Smith Park rally, the Klan also used Nellie Hale's funeral as a grand show of hooded power in St. Joseph. Despite a rain storm, an estimated twenty-five thousand people crowded the streets near the Hale's home to witness the funeral procession to Mount Mora Cemetery. The procession included roughly three hundred Klansmen, many choosing not to hide their identities. Klansmen also flanked automobiles carrying floral arrangements, the casket, and the Hale family. Reinforcing Exalted Cyclops William Campbell's claim that "we do not need any police here to keep order...we can maintain law and order ourselves," members of the Klan, not the police department, directed traffic along the funeral route. As the procession reached the cemetery, the rain ceased and the sun made a brief appearance in

\footnotetext{
${ }^{25}$ St. Joseph News-Press, 29 September 1921; St. Joseph Gazette, 29 September 1921, 1 October 1921, 2 October 1921; St. Joseph Observer, 1 October 1921; St. Joseph Catholic Tribune, 1 October 1921.

${ }^{26}$ St. Joseph Observer, 28 October 1922.
} 
the afternoon sky. When the graveside services concluded, the Klansmen left the cemetery and solemnly marched to their nearby klavern. ${ }^{27}$

With Hale's funeral concluded and the city's police commission still intact, St.

Joseph Klan No. 4 went forward with its plan to pursue a petition drive aimed at convincing Governor Hyde to remove the commissioners. This campaign was aided on two fronts. First, Hale's death became a national story in newspapers throughout the United States. ${ }^{28}$ In its own coverage of events, the St. Louis Post-Dispatch devoted multiple pages to explain "How Police Autocracy Aroused St. Joseph to Rebel Against Lawless Enforcement." 29 The national press also brought attention to the multiple police killings that had recently taken place in St. Joseph. Between May and October 1922, police in the city had killed Nellie Hale, two white men, one African American man, and a fellow officer. ${ }^{30}$ As such, the governor had to intervene in some form. A review of his correspondence from late 1922 reveals that Governor Hyde saw a dramatic increase in the amount of mail coming to his office advising him to monitor both police and Klan

27 St. Joseph News-Press, 23 October 1922.

${ }^{28}$ News of the death of Nellie Margaret Hale reached a national audience. The following newspapers ran articles about her funeral: St. Louis Post-Dispatch, 23 October 1922, 24 October 1922; Kansas City Journal, 21 October 1922, 22 October 1922, 23 October 1922; Atlanta Constitution, 23 October 1922; Des Moines Register, 23 October 1922; Tennessean 23 October 1922; Arkansas Gazette, 23 October 1922; Detroit Free Press, 23 October 1922; New York World, 22 October 1922; New York Herald, 23 October 1922; New York Tribune, 23 October 1922; Clippings from the New York World, New York Herald, New York Tribune can also be found in the National Association for the Advancement of Colored People Collection at the Library of Congress which indicates that the NAACP was keeping a close eye on the Hale controversy as well. Ku Klux Klan - October, 1922, Folder 9, Box C-314, NAACP, LOC.

${ }^{29}$ St. Louis Post-Dispatch, 29 October 1922.

${ }^{30}$ St. Louis Post-Dispatch, 29 October 1922; St. Joseph Gazette, 21 October 1922, 22 October 1922, 24 October 1922, 26 October 1922, 27 October 1922, 29 October 1922; St. Joseph News-Press, 21 October 1922, 23 October 1922. Willie Wright and Carl Schimpfesser were shot while allegedly fleeing from officers, while Dr. W.W. Wertenberger and Patrolman John House were hit by stray bullets fired by police in pursuit of other suspects. 
activity in St. Joseph. ${ }^{31}$ Hyde eventually convened a series of meetings in the city in November 1922, but he quickly announced that he would take no action against the police commission. ${ }^{32}$

Second, the Klan mobilized a large segment of St. Joseph's women's clubs, including the Independent Protestant Woman's Association and Grand League of Protestant Women of America, to back a petition drive. Traveling throughout town, these women secured thousands of signatures in preparation for delivery to the governor's mansion in Jefferson City. Their hard work did not go unnoticed, and hooded officials were more than happy to mention the role of women in the petition campaign and allow them use of St. Joseph's Klan Temple for meetings. ${ }^{33}$ Soon after, many of these women transitioned easily into roles within the local WKKK. Ultimately, the petition they helped craft and distribute made its way to Jefferson City and declared that "the constitutional rights of our people are being trampled under foot by the Police

\footnotetext{
${ }^{31}$ Neal Gallagher to Arthur Hyde, 20 October 1922, Folder 630, AMH, SHS-MO; H.J. Bowen to Arthur Hyde, 24 October 1922, Folder 630, AMH, SHS-MO; W.C. Pierce to Arthur Hyde, Western Union Telegram, 23 October 1922, Folder 630, AMH, SHS-MO; Unknown to Arthur Hyde, 23 October 1922, Folder 630, AMH, SHS-MO; Thomas Clark to Arthur Hyde, 23 October 1922, Folder 630, AMH, SHS-MO; John Downey to Arthur Hyde, 23 October 1922, Folder 630, AMH, SHS-MO; W.L. Mack to Arthur Hyde, 24 October 1922, Folder 630, AMH, SHS-MO; Brown to Arthur Hyde, 24 October 1922, Folder 630, AMH, SHSMO; Zerbst Pharmaceutical Company to Arthur Hyde, 25 October 1922, Folder 630, AMH, SHS-MO; Buchanan County Republican Central Committee to Arthur Hyde, 25 October 1922, Folder 630, AMH, SHSMO; Law Enforcement League to Arthur Hyde, Western Union Telegram, 23 October 1922, Folder 630, AMH, SHS-MO; H.P. Scruby to Arthur Hyde, 28 October 1922, Folder 630, AMH, SHS-MO; Maurice Ryan to Arthur Hyde, 30 October 1922, Folder 630, AMH, SHS-MO; C.E. Betts to Arthur Hyde, 10 November 1922, Folder 630, AMH, SHS-MO; John L. Barkley to Arthur Hyde, 23 November 1922, Folder 630, AMH, SHSMO; John L. Barkley to Arthur Hyde, 4 December 1922, Folder 630, AMH, SHS-MO.

32 St. Joseph News-Press, 28 November 1922; St. Joseph Gazette, 1 November 1922, 29 November 1922; Chillicothe Constitution and Nevada Mail dated 2 December 1922 in Folder 630, AMH, SHS-MO.

${ }^{33}$ Missouri Valley Independent, 4 January 1923, 18 January 1923, 25 January 1923, 1 February 1923, 8 February 1923, 15 February 1923, 22 February 1923, 8 March 1923, 15 March 1923, 4 April 1923, 12 April 1923, 19 April 1923, 26 April 1923, 3 May 1923.
} 
Department and citizens pursuing their lawful callings in public thoroughfares are being shot down by patrolmen." 34 Hyde was out of town due to a speaking engagement when the petition and a St. Joseph delegation including members of the Hale family and local Klansmen arrived. Yet, despite failing to meet with the governor over the matter, the Klan and its fourteen thousand signature petition drew positive headlines and demonstrated the strength of the organization. ${ }^{35}$

Building upon the concerns of women like the ones in St. Joseph, the WKKK slowly spread across Missouri soon after the conclusion of the petition drive. Noting increased activity in St. Louis, a WKKK advertisement in the Patriot declared that "Noble Womanhood Is Answering!"36 Within the state, the rise of the WKKK was tied to recruitment through traditional Klan avenues as well as the integration of rival women's groups into the organization, though separate clubs like the Protestant Women of Missouri and Kamelia continued to exist. ${ }^{37}$ By the mid-1920s, WKKK chapters existed in several locations throughout state, particularly St. Joseph, Kansas City, St. Louis, Jefferson City, and Joplin. ${ }^{38}$ The Missouri WKKK also grew due to a recruitment

\footnotetext{
${ }^{34}$ St. Louis Post-Dispatch, 29 October 1922.

35 St. Joseph News-Press, 29 October 1922; St. Joseph Gazette, 30 October 1922; St. Louis PostDispatch, 30 October 1922.

${ }^{36}$ Patriot, 27 July 1923.

${ }^{37}$ Missouri Valley Independent, 7 June 1923, 5 July 1923, 26 July 1923, 9 August 1923, 27 September 1923, 4 October 1923, 12 February 1925, 26 March 1925.

38 Patriot, 12 July 1923, 20 July 1923, 27 July 1923, 3 August 1923, 10 August 1923, 17 August 1923, 11 October 1923, 1 November 1923, 15 November 1923, 29 November 1923, 6 December 1923, 20 December 1923; Missouri Fiery Cross, 28 February 1924, 20 March 1924; Klan Kourier, 22 May 1924, 5 June 1924, 12 June 1924, 19 June 1924, 26 June 1924, 3 July 1924, 10 July 1924, 17 July 1924; Missouri Kourier, 1 August 1924, 5 September 1924; Missouri Valley Independent, 4 October 1923, 8 January 1925, 15 January 1925, 26 February 1925, 28 May 1925, 4 June 1925, 10 March 1927, 3 November 1927, 10 November 1927; Jefferson City Democrat-Tribune, 16 August 1924; Jefferson City Daily Capital News, 25
} 
campaign undertaken by the state's Klan-affiliated newspapers. Located in Klancontrolled St. Joseph, the Missouri Valley Independent was more than happy to publish the dates, locations, and summaries of WKKK events held in Missouri, particularly Buchanan County. ${ }^{39}$ Across the state in St. Louis, the Patriot reported on KKK and WKKK activity throughout the Midwest and Upper South. ${ }^{40}$ In addition to articles on the activities of Klanswomen in St. Louis, the Patriot also published commentaries from Lulu Markwell and James Comer on women's involvement in the Invisible Empire. ${ }^{41}$ By 1924, the newly named Missouri Kourier featured its own women's page dedicated to topics of interest for WKKK members, including articles on public education, literature, motherhood, and politics. ${ }^{42}$

While it had been relatively easy for the St. Joseph Klan and WKKK to portray themselves as the defender of white womanhood and public safety in the wake of Nellie Hale's murder, the organization as a whole did not experience similar success. At the

October 1924; Jefferson City Daily Post, 15 December 1924; Marion County Herald, 22 August 1924; Macon Daily Chronicle Herald, 2 May 1925; Joplin Globe, 22 September 1926;

${ }^{39}$ Missouri Valley Independent, 4 October 1923, 8 January 1925, 15 January 1925, 26 February 1925, 28 May 1925, 4 June 1925, 10 March 1927, 3 November 1927, 10 November 1927. These are specific examples of summaries of WKKK events. The Missouri Valley Independent had a section in each edition that listed the dates, times, and locations of KKK and WKKK weekly meetings.

40 Patriot, 12 July 1923, 20 July 1923, 27 July 1923, 3 August 1923, 10 August 1923, 17 August 1923, 11 October 1923, 1 November 1923, 15 November 1923, 29 November 1923, 6 December 1923,20 December 1923; Missouri Fiery Cross, 28 February 1924, 20 March 1924, Klan Kourier, 22 May 1924, 29 May 1924, 5 June 1924, 12 June 1924, 19 June 1924, 26 June 1924, 3 July 1924, 10 July 1924, 17 July 1924; Missouri Kourier, 1 August 1924, 5 September 1924. During its lifespan, the Patriot also changed its name to the Missouri Fiery Cross, Klan Kourier, and Missouri Kourier.

41 Patriot, 11 October 1923, 15 November 1923.

42 Missouri Kourier, 1 August 1924, 8 August 1924, 16 August 1924, 23 August 1924, 30 August 1924, 5 September 1924, 12 September 1924, 19 September 1924, 26 September 1924, 3 October 1924, 10 October 1924, 17 October 1924, 31 October 1924, 7 November 1924, 14 November 1924, 21 November 1924, 28 November 1924, 5 December 1924, 12 December 1924, 19 December 1924. 
time of Hale's death, the Klan continued to face accusations of violence and vigilantism. The argument from hooded officials that the organization disapproved of, and even distanced itself, from night-riding took a major hit when a group of vocal anti-Klan activists in Morehouse Parrish, Louisiana, were beaten and kidnapped by men in black masks in December $1922 .{ }^{43}$ Mer Rouge became a national story, and was, as historian Charles Alexander argues, "the most famous instance of Klan terrorism, and one of the best known murder cases of the 1920s." ${ }^{24}$ When the mystery of Mer Rouge reached a fever pitch in the national press, the Klan found itself once again in controversy.

Despite the Klan's attempts to downplay its vigilante past, any instance of collective violence - from threats and tar-and-featherings to bombings and lynchings brought intense scrutiny to the Invisible Empire. This was especially true in Missouri where a series of home bombings, violent attacks, and lynchings shook the state during the 1920s. While far from comparable to the sheer violence that occurred in other southern states during the early $20^{\text {th }}$ century, the numerous incidents in Missouri did draw national attention. They also brought scrutiny to local and state officials, particularly the gubernatorial administrations of Arthur Hyde and Sam Baker. But more than anyone else, these violent episodes were laid at the feet of the Ku Klux Klan. In reality, there is little evidence to tie the hooded order to all of these incidents. Nevertheless, it is important to study them to understand how a narrative developed, particularly among Klan opponents, that the organization's activities in the state inspired the bloodshed. Additionally, the Klan experienced recruitment problems in some of the communities

\footnotetext{
${ }^{43}$ Alexander, The Ku Klux Klan in the Southwest, 68-75.

${ }^{44}$ Alexander, The Ku Klux Klan in the Southwest, 68.
} 
impacted by vigilantism because the hooded order was unable to counter the image that it was an active participant in the violence.

In August 1923, the Klan affiliated Patriot decried the increasing African American population in many cities, particularly St. Louis. According to the Patriot, communities throughout the North were being "swamped" by southern blacks. ${ }^{45}$ When he arrived in St. Louis only days after the newspaper's commentary, Imperial Wizard Hiram Evans picked up on this growing discontent. Addressing a large crowd in East St. Louis, Evans devoted a portion of his speech to the topic of black migration. "I cannot help but sympathize with St. Louis and other Northern cities after reading about the socalled race problem," he told the audience, "the South has dealt successfully with the problem for years...regardless of what black agitators, vote snaring politicians or the newspapers have to say...[African Americans] can have his automobile, farm or whatever he wants, except social equality. ${ }^{46}$ Acknowledging that violence did happen in the South, though not necessarily condemning it, Evans reminded those assembled that "we have a lynching down there occasionally, I'll admit, but if I remember correctly, it was not so many months ago when you had one right here in Missouri. ${ }^{, 47}$

Although he did not elaborate on the specifics of the incident, those in the audience would have understood that Evans was referring to the April 1923 lynching of James T. Scott that took place in Columbia. Scott was one of fifty-eight African Americans lynched in Missouri between 1880 and 1930, but his death, along with two

\footnotetext{
45 The Patriot, 3 August 1923.

46 The Patriot, 10 August 1923.

47 The Patriot, 10 August 1923.
} 
others that will be discussed in this chapter, Roosevelt Grigsby and Walter Mitchell, was a grizzly "spectacle" that haunted the state of Missouri during the 1920s. ${ }^{48}$ As historian Amy Louis Wood argues "the cultural power of lynching - indeed, the cultural power of white supremacy itself - rested on spectacle: the crowds, the rituals and performances, and their sensational representations in narratives, photographs, and films...even one lynching reverberated, traveling with sinister force, down city streets and through rural farms, across roads and rivers."49

In order to understand what precipitated these lynchings and their influence on the Klan, it is important to survey the communities and regions of the state in which they are situated. Writing in 1938, Audrey Nell Kittel noted the economic, educational, and cultural qualities that defined James T. Scott's adopted hometown of Columbia, but she also saw that "its ideal qualities are almost wholly restricted to members of the white race...the disadvantages are reserved for its Negro citizens whose lives are characterized by physical ugliness and limited opportunities." ${ }^{\circ 0}$ Following Kittel's lead, scholar Doug Hunt describes 1920s Columbia in segregated terms:

If you were black, you stepped off the sidewalk when whites approached, and if you were male, you removed your hat. Law-abiding whites seldom ventured into a black neighborhood, unless they were 'friendly visitors' with Professor Ellwood's Public Welfare Society. In theory, blacks and women could hold public office and serve on juries, but in practice they didn't. A small set of

\footnotetext{
${ }^{48}$ Frazier, Lynchings in Missouri, 189-206. For a closer examination of the triple lynching in Springfield, Missouri in 1906 see Kimberly Harper, White Man's Heaven: The Lynching and Expulsion of Blacks in the Southern Ozarks, $1894-1909$ (Fayetteville: University of Arkansas Press, 2010).

${ }^{49}$ Amy Louis Wood, Lynching and Spectacle: Witnessing Racial Violence in America, 1890-1940 (Chapel Hill: University of North Carolina Press, 2009), 1-3.

${ }^{50}$ Audrey Nell Kittel, The Negro Community of Columbia, Missouri (Master's thesis, University of Missouri-Columbia, 1938), 10-13.
} 
prosperous white men dominated public life, and most others bore this dominance meekly. ${ }^{51}$

Historian Patrick Huber, in acknowledging the separation between whites and blacks, has also drawn a connection between the town's roots in Missouri's "Little Dixie" and race relations around the time of the lynching. As other scholars have noted, Little Dixie was historically the state's largest slaveholding region. It was an area that also consciously maintained southern traditions, including southern attitudes on race. ${ }^{52}$ In Huber's view, then, some members of Columbia's white population grew alarmed by local blacks' growing prosperity and assertiveness in the early 1920s. Scott came to represent black economic aspirations and the lynch mob stood in place for a community threatened by black mobility. ${ }^{53}$

The events that led to James T. Scott's lynching began on the afternoon of April 20, 1923, when Regina Almstedt, the fourteen year old daughter of university professor Hermann Almstedt, was attacked near the Stewart Bridge. On her way home, Regina

${ }^{51}$ Doug Hunt, Summary Justice: The Lynching of James Scott and the Trial of George Barkwell in Columbia, Missouri, 1923 (Charleston: n.p., 2010), 6-7.

52 The "Little Dixie" region encompasses land that resides on both sides of the Missouri River as it travels through the state. The total number of counties within Little Dixie varies in historical scholarship. But most scholars agree that the total number ranges from 7 to 17 . For resources that discuss the origins and history of Little Dixie see Perry McCandless, A History of Missouri: Volume II, 1820-1860 (Columbia: University of Missouri Press, 1972); Douglas R. Hurt, Agriculture and Slavery in Missouri's Little Dixie (Columbia: University of Missouri Press, 1992); Lorenzo J. Greene, Gary R. Kremer, and Antonio F. Holland, Missouri's Black Heritage: Revised Edition (Columbia: University of Missouri Press, 1993); Diane Mutti Burke, On Slavery's Border: Missouri's Small Slaveholding Households, 1815-1865 (Athens: University of Georgia Press, 2010); Aaron Astor, Rebels on the Border: Civil War, Emancipation, and the Reconstruction of Kentucky and Missouri (Baton Rouge: Louisiana State University Press, 2012); Kristen Epps, Slavery on the Periphery: The Kansas-Missouri Border in the Antebellum and Civil War Eras (Athens: University of Georgia Press, 2016).

${ }^{53}$ Patrick Huber, "The Lynching of James T. Scott: The Underside of a College Town," Gateway Heritage 12 no. 1 (1991), 1-15. 
passed by the perimeter of the University of Missouri campus and headed to the edge of the bridge by the urging of an African American man who informed her of a young child stuck in the ravine below. Regina followed the man into the ravine, as her testimony later indicated, where he attempted to rob the girl. Despite having a belt wrapped around her neck, Regina's attempts to fight off the man with her umbrella scared him and he fled. ${ }^{54}$ According to Patrick Huber, after news spread about the attack, "hysteria clutched the white community" and local press coverage, especially the from the Columbia Daily Tribune, "stoked the combustible situation with inflammatory coverage of the assault." ${ }^{55}$ Fanning the flames of outrage over recent attacks upon women in Columbia, including Regina Almstedt, Tribune editor E.M. Watson declared:

These brutes and super-criminals should be dealt swift justice by the courts, of course. There can be no extenuation of their crimes. Murder and homicide can be committed under stress of anger or insult, but the rapist is guilty of premeditation, malice - in fact every degrading and criminal act. A man killer is a mild mannered and desirable citizens compared with a despoiler and ravisher of innocent girlhood. An attempt at the crime above mentioned is just as heinous and culpable as an accomplishment. ${ }^{56}$

While local police rounded up African American men from Columbia and neighboring Boone County communities for questioning, Regina's description of her attacker soon led investigators to James T. Scott, a janitor for the university's medical school. Scott was a notable figure in Columbia because his position at the university paid

\footnotetext{
${ }^{54}$ Hunt, Summary Justice, 8-9; Huber, "The Lynching of James T. Scott," 3.

${ }^{55}$ Huber, "The Lynching of James T. Scott," 2.

${ }^{56}$ Columbia Daily Tribune, 28 April 1923.
} 
him the equivalent of white male janitors and he owned an automobile which was a distinction that few working class members of Columbia society, white or black, could claim. Yet police were not concerned about Scott's standing as "an honest and industrious father" in Columbia's black community; instead, they focused in on his appearance. ${ }^{57}$ Unfortunately, Scott matched all three key features that Regina Almstedt claimed of her attacker: 1) He was a black man in his thirties; 2) He had a Charlie Chaplin-style mustache; 3) His work at the medical school left him with the strong smell of chemicals at the end of his shift. ${ }^{58}$

As soon as Scott's name appeared in the press as the possible attacker, rumors of a lynch mob began to circulate in Boone County. Instead of moving Scott to a neighboring county, local officials felt confident that the jail could repel any attack. However, using hammers, chisels, and ultimately an acetylene torch, a mob broke into the jail and forcefully removed Scott from his cell. Pleading his innocence as he was forcefully marched to the nearby Stewart Bridge, Scott soon found himself surrounded by a crowd numbering in the thousands. As Scott prepared for his final moments of life, Hermann Almstedt appeared at the bridge and demanded that the mob disperse so that the courts could handle the punishment. After threatening Almstedt with violence, and ignoring Scott's final pleas, the mob placed a noose around Scott's neck and threw his body over the bridge. ${ }^{59}$ The rope went tight. A snap echoed through the ravine. And the “spectacle” was over.

${ }^{57}$ Hunt, Summary Justice, 8-9; Huber, "The Lynching of James T. Scott," 3; The quote describing Scott as honest and industrious comes from the Chicago Defender, 12 May 1923.

${ }^{58}$ Hunt, Summary Justice, 8-9.

${ }^{59}$ Hunt, Summary Justice, 20-36; Huber, "The Lynching of James T. Scott," 4-6. 
Even before Scott's death, his arrest had attracted enough attention that the NAACP opted to send representatives to Columbia to participate in the impending court case. ${ }^{60}$ Due to his prior work with the St. Louis NAACP, particularly its anti-Klan campaign, attorney George L. Vaughn was called upon to aid Scott. While Vaughn was unable to defend Scott in a court of law, his eyewitness retelling of the lynching was soon splashed across the pages of newspapers in the United States, Canada, and England, including the New York Times, Chicago Daily Tribune, Kitchener (Ontario) Daily News Record, and London Times. ${ }^{61}$ The Chicago Defender even went so far as to compare the celebration of black athletes at one college to the lynching of a black man at the seat of Missouri's state institution. ${ }^{62}$ Executive Secretary of the NAACP, James Weldon Johnson, issued an op-ed to newspapers nationwide declaring that "this outrage...is one of the best concrete arguments for passage of a Federal antilynching bill that could possibly be adduced." ${ }^{\circ 3}$ Writing for the The Crisis, W.E.B. DuBois mocked Columbia in a sharp critique:

We are glad to note that the University of Missouri has opened a course in Applied Lynching... We are very much in favor of this method of teaching 100 per cent Americanism; as long as mob murder is an approved institution in the United States, students at the universities

${ }^{60}$ Doug Hunt, Summary Justice: The Lynching of James Scott and the Trial of George Barkwell in Columbia, Missouri, 1923 (Charleston: n.p., 2010), 16-17.

${ }^{61}$ New York Times, 30 April 1923; Chicago Daily Tribune, 30 April 1923; London Times, 1 May 1923; Kitchener Daily News Record, 1 May 1923. A copy of the Kitchener Daily News Record can be found in Folder 9, Box C-361, NAACP, LOC.

${ }^{62}$ Chicago Defender, 5 May 1923, 12 May 1923.

${ }^{63}$ For a list of newspapers that received Johnson's editorial see "The Scott Lynching," James Weldon Johnson Editorial, 2 May 1923, Folder 9, Box C: 361, NAACP, LOC. 
should have a firsthand chance to judge exactly what a lynching is. ${ }^{64}$

Following Scott's death, the NAACP, along with several state-wide interracial organizations, pressured public officials, particularly Governor Hyde, into devoting their full attention to the lynching. ${ }^{65}$ "We are acting upon the principle of holding the state and local authorities strictly to account for vigorous action in the matter," John L. Love of the Kansas City NAACP wrote to Walter White, "[and] sentiment in the state is unanimous for such action and the authorities seem to realize it." 66 Within hours of Scott's death, the Kansas City NAACP called a mass meeting to demand that state officials punish those involved in the lynching. ${ }^{67}$ Local members advised Governor Hyde that "a hasty

${ }^{64}$ W.E.B. Du Bois, “A University Course in Lynching," The Crisis 26, no. 2 (June 1923), 55.

65 J.W. Hurse to Arthur Hyde, 30 April 1923, Folder 107, AMH, SHS-MO; Charles W. Tadlock to Arthur Hyde, 30 April 1923, Folder 107, AMH, SHS-MO; W.D. Wilkins to Arthur Hyde, 30 April 1923, Folder 107, AMH, SHS-MO; Elbert B. Hamlin to Arthur Hyde, 30 April 1923, Folder 107, AMH, SHS-MO; Ida M. Becks to Arthur Hyde, 30 April 1923, Folder 107, AMH, SHS-MO; Lillian Campbell to Arthur Hyde, n.d., Folder 107, AMH, SHS-MO; C.A. Franklin to Arthur Hyde, 30 April 1923, Collection 7, AMH, SHS-MO; Benevolent Order of Peerless Knights to Arthur Hyde, 1 May 1923, Folder 108, AMH, SHS-MO; Mrs. Russell Fields to Arthur Hyde, 2 May 1923, Folder 108, AMH, SHS-MO; Mrs. T.A. Witten to Arthur Hyde, 2 May 1923, Folder 108, AMH, SHS-MO; Mrs. Edward Cushing to Arthur Hyde, 3 May 1923, Folder 108, AMH, SHS-MO; Floyd S. Webb to Arthur Hyde, 8 May 1923, Folder 108, AMH, SHS-MO; The City Federation of Colored Women's Club to Arthur Hyde, 11 May 1923, Folder 108, AMH, SHS-MO; A.W. Lloyd to Arthur Hyde, Western Union Telegram, 3 May 1923, Folder 108, AMH, SHS-MO; Arthur Armstrong to Arthur Hyde, 10 May 1923, Folder 108, AMH, SHS-MO; Nick Chiles to Arthur Hyde, 31 May 1923, Folder 108, AMH, SHS-MO; Governor's Secretary to C.A. Franklin, 3 May 1923, Folder 108, AMH, SHS-MO; Governor's Secretary to Edward F. Cushing, 4 May 1923, Folder 108, AMH, SHS-MO; Governor's Secretary to Elbert Hamlin, 4 May 1923, Folder 108, AMH, SHS-MO; Arthur Hyde to Floyd S. Webb, 9 May 1923, Folder 108, AMH, SHS-MO; Arthur Hyde to Floyd S. Webb, 9 May 1923, Folder 108, AMH, SHS-MO; Arthur Hyde to Elbert Hamlin, 8 May 1923, Folder 108, AMH, SHS-MO; Arthur Hyde to Lillian Campbell, 15 May 1923, Folder 108, AMH, SHS-MO; Arthur Hyde to Arthur Armstrong, 8 May 1923, Folder 108, AMH, SHSMO; Columbia Missourian, 1 May 1923; St. Louis Argus, 4 May 1923, 11 May 1923; Kansas City Call, 4 May 1923.

${ }^{66}$ John L. Love to Walter White, 17 May 1923, Folder 23, Box G: 107, NAACP, LOC.

${ }^{67}$ John L. Love to Arthur Hyde, 29 April 1923, Western Union Telegram, Folder 107, AMH, SHSMO; John L. Love to Walter White, 30 April 1923, Western Union Telegram, Folder 9, Box C: 361, NAACP, LOC. 
reformation may be made in the governmental affairs of our state." ${ }^{68}$ In St. Louis, the NAACP expressed concerns about the inability to identify mob members despite the fact that "wealthy and influential citizens" were seen near the jail. ${ }^{69}$ Writing from New York, James Weldon Johnson warned Hyde that "the eyes of the nation are upon Missouri to be shown whether anarchy or law will prevail."70 The governor denied accusations made by Johnson and others that law enforcement officials refused to stop the attack because they were actually in the lynch mob, but he did subsequently order an investigation into the actions of the National Guard. ${ }^{71}$

With its call for accountability among state officials, the NAACP also used the Scott lynching as a recruiting tool in Missouri. "We all have seen and now know that our salvation as a race lies in our ability to organize... we must hang-to-gether [sic] for our own protection, or we will hang separate as James Scott did at Columbia," the St. Louis Argus warned its readers, "[t]he National Association for the Advancement of Colored People has the machinery, all you have to do is to join."72 By mid-May, Dr. William J. Thompkins of Kansas City sent a list of twenty African American leaders and their respective home communities to the NAACP in the hopes of establishing new branches.

${ }^{68}$ Ida M. Becks to Arthur Hyde, 16 May 1923, Folder 108, AMH, SHS-MO.

${ }^{69}$ George L. Vaughn to Arthur Hyde, 30 April 1923, Folder 107, AMH, SHS-MO; George L. Vaughn to Walter White, 2 May 1923, Folder 9, Box C: 361, NAACP, LOC; James H. Tanter to Walter White, 2 May 1923, Folder 9, Box C: 361, NAACP, LOC.

70 James Weldon Johnson to Arthur Hyde, 30 April 1923, Western Union Telegram, Folder 107, AMH, SHS-MO.

71 James Weldon Johnson to Arthur Hyde, 7 May 1923, Folder 108, AMH, SHS-MO; James Weldon John to Arthur Hyde, 7 May 1923, Folder 9, Box C: 361, NAACP, LOC; Arthur Hyde to James Weldon Johnson, 9 May 1923, Folder 108, AMH, SHS-MO; Arthur Hyde to James Weldon Johnson, 9 May 1923, Folder 9, Box C: 361, NAACP, LOC; St. Louis Argus, 4 May 1923; 20 July 1923.

72 St. Louis Argus, 4 May 1923. 
The idea passed between Robert Bagnall, Walter White, and James Weldon Johnson before Bagnall sent out inquiries to the individuals on the list. However, it is unclear how many of these communities immediately rallied to organize a branch. ${ }^{73}$ Even Columbia, still simmering with racial tension, had trouble forming a branch. When a town resident wrote to Walter White in 1928 about establishing a branch at Columbia, White reminded him that NAACP activity had ceased in the community at some point in the mid-1920s. ${ }^{74}$ In addition to the NAACP, the Urban League was also concerned about the fallout over the Scott lynching. Writing on behalf of the Columbia chapter, Charles Ellwood, Professor of Sociology at the University of Missouri, informed National Urban League officials that "conditions are very bad here in Columbia... [and] if I did very much, a certain element here would run me out of town."75 Ellwood's concerns about the town were very much justified. His stances on issues like evolution, religion, race relations, law enforcement, and the Klan made him a controversial figure in Columbia, and he had already received intense scrutiny for critical remarks he made to the St. Louis Star about the town's morality in the wake of the lynching. ${ }^{76}$ Yet, as he later told Frederick Libby

\footnotetext{
73 Walter White to Robert Bagnall, 15 May 1923, Folder 11, Box G: 222, NAACP, LOC; Walter White to James Weldon Johnson, 15 May 1923, Folder 11, Box G: 222, NAACP, LOC; Robert Bagnall to A.E. Moore, 26 May 1923, Folder 11, Box G: 222, NAACP, LOC. Only one letter from Robert Bagnall to an individual on the list was found by the author. Jefferson City was included on the list as a possible community, but by that time it already had a branch.

74 Jas. H. Jackson to Walter White, 22 February 1928, Folder 10, Box G: 107, NAACP, LOC; Director of Branches to Jas. H. Jackson, 28 February 1928, Folder 10, Box G: 107, NAACP, LOC.

${ }^{75}$ Charles A. Ellwood to Eugene K. Jones, 5 May 1923, Folder: Correspondence 1923, Box 1, CAE, RL, DUKE-NC.

${ }^{76}$ Charles A. Ellwood, "A History of the Department of Sociology in the University of Missouri," Folder 10, Box 1, Luther Lee Bernard Papers, Special Collections Research Center, University of Chicago Library, Chicago, Illinois; St. Louis Star, 30 April 1923, 1 May 1923; Columbia Daily Tribune, 1 May 1923,2 May 1923; Hunt, Summary Justice, 38-39.
} 
of the National Council for Prevention of War, the death of James T. Scott had a major impact on his life."77 Ellwood had tried, but failed, to prevent violence when he warned town officials to move Scott out of Columbia and advised Governor Hyde to call up the National Guard to suppress the mob. ${ }^{78}$ He later allegedly told one of his sociology classes that "you cannot have a lynching... unless a lot of people in the community believe in lynching."79 Despite intense opposition to his comments in the local press, Ellwood did receive letters of support from Governor Hyde and acting university president Isidor Loeb. ${ }^{80}$

Though there was intense national and state-wide pressure to identify mob members and bring them to justice, Boone County residents quickly developed an acute sense of amnesia. ${ }^{81}$ Prosecuting Attorney Ruby Hulen had trouble collecting information, but was eventually able to bring evidence related to five men, including prominent Columbia resident George Barkwell, before a grand jury. ${ }^{82}$ By the time of the trial, evidence had also surfaced to suggest that James T. Scott was innocent. Many in

\footnotetext{
${ }^{77}$ Charles Ellwood to Frederick J. Libby, 10 November 1944, Folder: Correspondence 1941-1944, Box 4, CAE, RL, DUKE-NC.

${ }^{78}$ St. Louis Star, 1 May 1923.

${ }^{79}$ St. Louis Star, 30 April 1923, 1 May 1923; Columbia Daily Tribune, 1 May 1923, 2 May 1923; Hunt, Summary Justice, 38-39.

${ }^{80}$ Arthur Hyde to Charles Ellwood, 7 May 1923, Folder 108, AMH, SHS-MO; Arthur Hyde to Charles Ellwood, 7 May 1923, Folder: Correspondence 1923, Box 1, CAE, RL, DUKE-NC; Isidor Loeb to Charles Ellwood, 12 May 1923, Folder: Correspondence 1923, Box 1, CAE, RL, DUKE-NC. Ellwood also received a letter of support from former Missouri governor Herbert Hadley. Herbert Hadley to Charles Ellwood, 2 June 1923, Folder: Correspondence 1923, Box 1, CAE, RL, DUKE-NC.

81 Jefferson City Daily Capital News, 1 May 1923; Auxvasse Review, 2 May 1923; Ashland Bugle, 3 May 1923.

82 Petitions from several Boone County communities asking Ruby Hulen to drop all charges against the indicted mob members were so numerous that they had to be collected in local banks. Columbia Missourian, 13 July 1923, 16 July 1923.
} 
the African American community felt that Ollie Watson, not Scott, was Regina Amnstedt's attacker because Watson, who had recently shaved his Charlie Chaplin-style mustache, had been in prior legal trouble, including an arrest in a neighboring community on a charge of attempted rape ${ }^{83}$ However, despite growing claims of Scott's innocence, and testimony from University of Missouri student Charles Nutter that he could identify the main mob members, George Barkwell was found not guilty at his trial. The other cases were soon dropped. The cheering reaction of the crowd and the jury's short deliberation time of thirty minutes left the Chicago Defender to lament that "[you] can't jail a white man in Columbia." ${ }^{84}$ The Columbia Missourian condemned the lack of prosecution in the case and argued that "the stain remains." 85

As residents of central Missouri withstood the fallout over the lynching of James T. Scott, recruiters for the Ku Klux Klan spread out across Little Dixie. During the spring and summer of 1923, kleagles preached the message of one hundred percent Americanism to potential members throughout the region. Yet, despite prior gains in communities like St. Joseph and Joplin, Little Dixie proved to be problematic for the hooded order. When recruiters showed up in Columbia, Tribune editor E.M. Watson warned that "if there are agitators of this miserable ilk in Columbia, they had best desist at once from any attempt to terrorize this community with their highhanded, unlawful and

83 T.A. Curtis to Arthur Hyde, 7 July 1923, Folder 108, AMH, SHS-MO; Hunt, Summary Justice, 8687; St. Louis Argus, 6 July 1923. Ollie Watson was later found guilty of rape and given a lengthy prison sentence in a separate case.

${ }^{84}$ Chicago Defender, 21 July 1923.

${ }^{85}$ Columbia Missourian, 13 July 1923. 
anarchistic methods." 86 The Tribune was joined in its denouncement of the hooded order by the Columbia Missourian which declared that the town had "little of the crime which the Klan spokesman say they will eradicate... we have few criminals and no racial or religious trouble." ${ }^{87}$ While recruiters may have faced early opposition in Columbia, there was slightly more promise in nearby Centralia where the local Courier claimed that early membership totals topped out at ten, though the newspaper was also quick to point out anti-Klan sentiments that existed throughout Boone County. ${ }^{88}$ For 1923, at least, it seemed that E.M. Watson's words would come true and that the county would be an "arid field indeed for the slimy, filthy head of the 'invisible empire'." 89

The Klan initially found similar opposition in nearby Jefferson City. Located roughly thirty miles from Columbia, Jefferson City was the state's capitol and stood as a key prize for the Invisible Empire. Yet, Cole County proved to be just as anti-Klan as neighboring Boone County. After Klansmen set fiery crosses at locations throughout the city and rumors circulated about a planned Klan parade, Jefferson City mayor C.W. Thomas appointed extra deputies to keep the peace. ${ }^{90}$ The Patriot later claimed that Thomas named mostly Catholic deputies to serve as a deterrent to Klan activity. ${ }^{91}$ Klansmen also felt pressure from local editor Joseph Goldman who wrote in the Jefferson City Democrat Tribune that "I am against this organization, not because I am a Jew, but

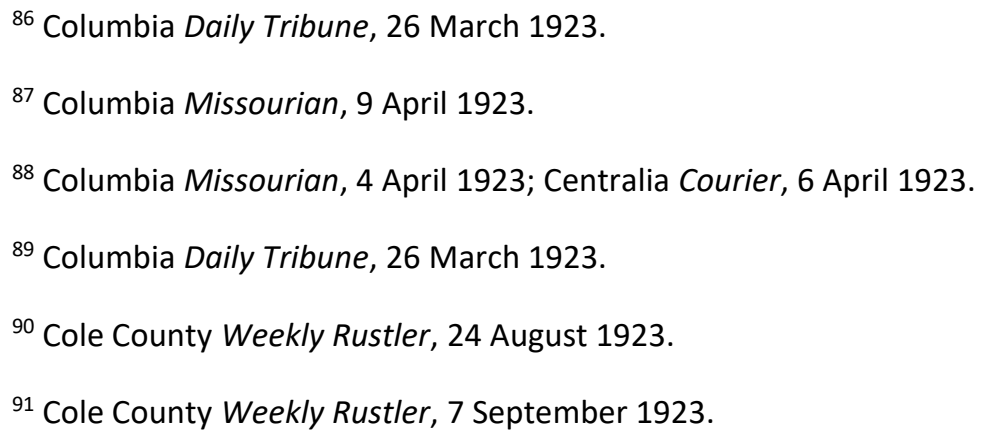


because I believe first in the government of the United States."92 Goldman's warning against "masked malcontents" drew the ire of the Patriot which referred to the editor as "Jew Joe."93 While Thomas and Goldman utilized public venues to show their opposition, some county residents did so under cover of darkness. In a manner very similar to the Klan's night-riding that drew public condemnation, a group of unidentified men loaded up in a dark-colored Ford touring car and fired upon properties allegedly owned by Klansmen, including the offices of the Daily Post which was edited by Exalted Cyclops Heber Nations. Local opinion suggested that the bullets were a response to the crosses, but at least four of the victims denied having any involvement with the Klan. ${ }^{94}$ The men in the mysterious automobile were never identified.

As townspeople swept up broken glass and discarded the charred remains of crosses, Jefferson City residents spoke out against the violence. Rev. W. Hooper Adams of First Presbyterian Church denounced the nighttime shootings in a Sunday sermon. ${ }^{95}$ Sam B. Cook, a former state senator and president of Central Missouri Trust Company, shared Adams' sentiments and called on local law enforcement to solve the crimes before Jefferson City became a "wild west town."96 Looking to aid local police, community

\footnotetext{
92 Jefferson City Democrat-Tribune, 18 September 1923

93 Jefferson City Democrat-Tribune, 24 August 1923.

94 Jefferson City Daily Capital News, 24 August 1923, 2 October 1923; Jefferson City Democrat-
} Tribune, 1 October 1923. Despite their denial of any ties to the Klan, two of the individuals targeted, Paul Radke and Claud Bartlett, were later found to be Klansmen.

${ }^{95}$ Rev. W. Hooper Adams' comments are significant because he was later accused of being sympathetic to the Klan. This charge was strengthened when the Klan presented Adams with a donation following his final sermon before retiring for health reasons. For information on Adams and the Klan see Jefferson City Democrat Tribune, 17 November 1924, 15 December 1924.

96 Jefferson City Daily Capital News, 3 October 1923. 
members contributed close to $\$ 1000$ towards a reward for information leading to the arrests of those responsible for the shootings. ${ }^{97}$ In a published address, mayor C.W. Thomas warned local residents that the "burning of fiery crosses and shooting into homes and business places have given our city a reputation it does not deserve...lawlessness and intimidation are the weapons of cowards and the perpetrators should be punished to the full extent of the law." "If Jefferson City is to continue its steps forward," Thomas declared, "we must all join together, Protestant, Catholic and Jew...we must know no creed or no color but work for the common good of the community."98 The Daily Capital News issued a "call to citizenship" declaring:

Jefferson City cannot permit its citizenship to be split and its future impaired because of the actions of hot heads and it behooves every safe and sane resident of the city to see that the fanatics do not tear down what it has taken generations to construct... We must not be torn asunder like other places have been, but instead, must stand as one for good citizenship and for Jefferson City...If there be $\mathrm{a} \mathrm{Ku}$ Klux Klan here, and we believe there is, it behooves the leaders to live up to their claim of 100 per cent Americanism, which does not mean arraying friend against friend or sect against sect...The government of the United States was founded upon the principle of religious liberties, which guarantee to every person the right to worship God according to his or her own conscience, and that should be the guide post for us all...The Capital News takes its hat off to no one in its devotion to the principles of Americanism and it stands for everything that is good for Jefferson City and its future, but we can see no reason for the people of the city being split into small groups and the town being allowed to die of dry rot. ${ }^{99}$

97 Jefferson City Democrat-Tribune, 2 October 1923, 3 October 1923; Jefferson City Daily Capital News, 3 October 1923, 4 October 1923.

98 Jefferson City Daily Capital News, 3 October 1923; Jefferson City Democrat-Tribune, 3 October 1923.

99 Jefferson City Daily Capital News, 24 August 1923. 
Despite the high level of opposition in Jefferson City - including comments by the Democrat-Tribune that "the once peaceful and progressive city has been torn asunder and business is slowly but surely becoming paralyzed" due to the organization of the Klan Cole County residents still joined the Invisible Empire. ${ }^{100}$ The Patriot proudly announced that Missouri's capitol city was "swarming with citizen-Klansmen."101 The Fulton Daily Sun estimated that the Cole County hooded population stood at between three hundred and five hundred. ${ }^{102}$ By the start of 1924, the Jefferson City Klan had spread its influence throughout Cole County and had begun to make headways in neighboring Callaway County where hooded members lacked a unified organization. It would be several months before the first cross burning occurred in the county seat of Fulton, but Klan activity increased in the area in 1924 due to the growth of the hooded order in New Bloomfield, Mokane, and Jefferson City. ${ }^{103}$ Nevertheless, the Fulton Daily Sun was quick to point out that sentiments within the northern half of Callaway County still leaned towards opposition to the Klan. ${ }^{104}$

While portions of Cole and Callaway counties had fallen under the sway of the Invisible Empire, the Klan failed to spread its message publicly in neighboring Boone County until nearly a year after the Scott lynching. Besides the initial growth in Centralia

100 Jefferson City Democrat-Tribune, 1 October 1923.

101 The Patriot, 12 July 1923.

102 Fulton Daily Sun, 18 August 1923.

103 Fulton Daily Sun, 21 August 1923, 23 August 1923, 12 May 1924; Fulton Gazette, 23 August 1923, 20 September 1923, 8 November 1923, 29 November 1923, 27 December 1923, 15 May 1924; Fulton Missouri Telegraph, 15 May 1924; Mokane Missourian, 30 November 1923, 28 December 1923.

${ }^{104}$ Fulton Daily Sun, 20 August 1923. 
where the Courier suspected that "several [people] have dug down for the ten dollar initiation fee," newspapers in Little Dixie took notice of the lack of Klan support in Boone County. ${ }^{105}$ This is not to say, however, that there was little interest in the Klan in Columbia. A large crowd gathered at Lover's Leap when rumors circulated of a Klan appearance, but they disbanded in the early morning hours when no robed figures arrived. ${ }^{106}$ After the incident, the Missourian declared that the "burning cross had not burned; the white hooded figures had not appeared, and Columbia was still without the Klan."107 If Columbia residents were eager for the Klan to arrive, the organization finally did so in a display of fiery crosses and other activities throughout the town in early 1924. ${ }^{108}$ Yet despite the appearance of burning crosses, the Tribune assured its readers that it felt "secure in the knowledge that secret rituals and devices, accompanied by violence and disregard of the law and the infringement of rights of individuals cannot survive in a free, fine, liberty loving country, such as ours." 109

As Klansmen made their way through Little Dixie in search of recruits, their brethren in southeast Missouri were doing the same in the state's cotton belt. Despite predictions of a large crop, and confidence from the Cape Girardeau Southeast Missourian that cotton would ensure that the region was "destined to become the richest agricultural district of the United States," Klan recruiters found uneasiness throughout the

${ }^{105}$ Centralia Courier, 6 April 1923, 17 July 1923; Fulton Gazette, 19 July 1923.

${ }^{106}$ Columbia Herald Statesman, 2 August 1923.

${ }^{107}$ Columbia Missourian, 31 July 1923.

108 Columbia Herald Statesman, 21 January 1924, 11 February 1924; Columbia Daily Tribune, 28 January 1924; Missouri Fiery Cross, 7 February 1924.

${ }^{109}$ Columbia Daily Tribune, 12 February 1924. 
region. Tensions between white and black agricultural laborers lingered after African American voters had been warned to stay away from the polls during the prior election and pamphlets bearing skulls and crossbones and signed "K-K-K" were distributed in Pemiscot County."110 The threat of violence was not new for the region as six black men had been lynched in the cotton belt since 1902. Additionally, when wealthy landowners attempted to bring in blacks for agricultural work prior to 1920, white tenant farmers responded with vigilantism to drive out the competing laborers. In fact, Missouri's entire southern border experienced an intense period of racial violence between 1890 and 1920, punctuated by two triple lynchings in Lawrence County and Greene County. ${ }^{111}$ At the start of the 1920s, Missouri's "bootheel" was known more for its wheat and corn than its cotton. In fact, large-scale agricultural production in the region was relatively new following the successful draining of swamp land in the early $20^{\text {th }}$ century. ${ }^{112}$ What little cotton that was produced struggled on the open market after the nation's economy experienced a depression following World War I and an intense boll weevil infestation in the American South left many to wonder if cotton was still a premier crop. By 1922, however, cotton became the crop of southeast Missouri and emerged as the savior of the region thanks to its hardy nature in the reclaimed swamp land. The

\footnotetext{
110 Southeast Missourian, 12 January 1923, 18 January 1923; St. Louis Post-Dispatch, 29 October 1922; James L. Jackson to Arthur Hyde, 6 November 1922, Folder 366, AMH, SHS-MO; Arthur Hyde to James L. Jackson, 9 November 1922, Folder 366, AMH, SHS-MO; Paul Burton to Arthur Hyde, 8 November 1922, Folder 366, AMH, SHS-MO.

${ }^{111}$ Harper, White Man's Heaven, 1-234; Thelen, Paths of Resistance, 92-99; Bonnie Stepenoff, Thad Snow: A Life of Social Reform in the Missouri Bootheel (Columbia: University of Missouri Press, 2003), 21; Frazier, Lynchings in Missouri, 105-162.

112 Roll, Spirit of Rebellion, 52, 56-58; Joel P. Rhodes, A Missouri Railroad Pioneer: The Life of Louis Houck (Columbia: University of Missouri Press, 2008), 254-273; Stepenoff, Thad Snow, 9-22.
} 
state's cotton would never rival its sister crop farther south, but the bootheel's agricultural potential led to increased interest in the region. ${ }^{113}$

As the cotton crop moved north, so too did thousands of African Americans. Seeking a way out of economic limitations, racial violence, and the hardening of Jim Crow, most African Americans relocated to urban locations in the North and West. ${ }^{114}$ Some, however, kept their agricultural roots and moved to farming communities on the outskirts of the South. ${ }^{115}$ Despite its place along the lower half of the Mississippi River Valley, Missouri's cotton belt did not completely replicate the South. Reflecting on his life in southeast Missouri, wealthy planter Thad Snow noted that "the people of the Delta thought and behaved like people of the North rather than like people of the Cotton South." 116 However, though the state lacked an official system of de-jure style Jim Crow segregation, Snow acknowledged an "overlordship [sic] that was mildly intoxicating" when it came to relations between white planters and black laborers. ${ }^{117}$

While cultural segregation, discriminatory practices, and overt racism were still quite evident, Missouri differed from other cotton-producing states in that African

${ }^{113}$ Roll, Spirit of Rebellion, 52, 56-58; Stepenoff, Thad Snow, 53-60.

${ }^{114}$ Isabel Wilkerson, The Warmth of Other Suns: The Epic Story of America's Great Migration (New York: Random House, 2010), 8-15; Carol Anderson, White Rage: The Unspoken Truth of Our Racial Divide (New York: Bloomsbury Publishing, 2016), 39-66; Leon F. Litwack, Trouble in Mind: Black Southerners in the Age of Jim Crow (New York: Alfred A. Knopf, 1998), 481-496; Steven Hahn, A Nation Under Our Feet: Black Political Struggles in the Rural South from Slavery to the Great Migration (Cambridge: Harvard University Press, 2003), 455-468.

${ }^{115}$ Roll, Spirit of Rebellion, 53; Hahn, A Nation Under Our Feet, 468-476.

116 Thad Snow, From Missouri: An American Farmer Looks Back, ed. Bonnie Stepenoff (Columbia: University of Missouri Press, 2012), 123.

117 Snow, From Missouri, 123. 
Americans had voting rights and held positions of power in state politics. ${ }^{118}$ The promise of a better life and better opportunities brought roughly fifteen thousand African Americans into the Missouri cotton belt counties of Butler, Scott, Stoddard, Pemiscot, Mississippi, Dunklin, and New Madrid between 1910 and 1930. ${ }^{119}$ They quickly found landowners ready to employ them and organizations like the UNIA and NAACP ready to aid them, but they also discovered resistance among the large class of white tenant farmers. Black and white laborers shared a lot in common in the cotton belt, but as the increasing African American population began to compete for jobs, and landowners expressed a preference for black workers over white workers, violence escalated. ${ }^{120}$

After additional reports of black intimidation in southeast Missouri, including notes allegedly tacked onto homes proclaiming "get out...this is a white man's country," filtered into his Jefferson City office, Governor Arthur Hyde demanded answers. ${ }^{121} \mathrm{He}$ wired the sheriffs of Pemiscot, Dunklin, Mississippi, and Scott counties to inquire about the validity of such claims. He reminded the men that it was their duty to maintain order and protect the citizens of their counties. ${ }^{122}$ Hyde also forwarded information, including

118 Greene, Kremer, Holland, Missouri's Black Heritage, 140-151.

119 U.S. Bureau of the Census, Thirteenth Census of the United States: 1910, vol. 2: Population, 1101-1120; U.S. Bureau of the Census, Fourteenth Census of the United States: 1920, vol. 2: Population, 551-561; U.S. Bureau of the Census, Fifteenth Census of the United States: 1930, vol. 2: Population, 13391346.

${ }^{120}$ Roll, Spirit of Rebellion, 52-75.

${ }^{121}$ Southeast Missourian, 18 January 1923, 6 February 1923, 14 February 1924; St. Louis Argus, 2 February 1923, 2 March 1923; Kansas City Call, 9 February 1923, 2 March 1923; St. Louis Star, 1 March 1923, 2 March 1923.

122 Arthur Hyde to W.P. Robertson, 28 February 1923, Western Union Telegram, Folder 107, AMH, SHS-MO; Arthur Hyde to J.W. Timberman, 28 February 1923, Western Union Telegram, Folder 107, AMH, SHS-MO; Arthur Hyde to C.D. Jackson, 28 February 1923, Western Union Telegram, Folder 107, 
a copy of one of the "K-K-K" election flyers, on to United States Attorney General Harry Daugherty and the Department of Justice. ${ }^{123}$ Hyde felt pressure to act on the threats after the United States District Attorney's office in St. Louis went public with numerous complaints of assaults and intimidation it had received from black tenant farmers and white landowners in Dunklin and Pemiscot counties. ${ }^{124}$ Hyde's inquiries were met with hostility from local residents who disputed the charges. The Caruthersville Chamber of Commerce and Kennett Lions Club, along with several cotton belt newspapers, protested against the accusations of African American intimidation published in the St. Louis press. ${ }^{125}$ Most of the sheriffs told Hyde that the press coverage of the supposed violence was greatly exaggerated and that "peace and quiet prevails here."126

In light of the reports received by the Justice Department, and concerns about the response from county sheriffs, Hyde sent additional messages to allies in southeast Missouri inquiring about the facts of the situation. ${ }^{127}$ Some correspondents corroborated AMH, SHS-MO; Arthur Hyde to W.E. Kirkendall, 28 February 1923, Western Union Telegram, Folder 107, AMH, SHS-MO.

${ }^{123}$ Arthur Hyde to Edward Hays, 23 September 1923, Folder 367, AMH, SHS-MO; Edward Hays to Arthur Hyde, 26 September 1923, Folder 367, AMH, SHS-MO; Arthur Hyde to Harry Daugherty, 28 September 1923, Folder 367, AMH, SHS-MO; Assistant Attorney General to Arthur Hyde, 28 October 1923, Folder 367, AMH, SHS-MO.

${ }^{124}$ St. Louis Post-Dispatch, 28 February 1923.

125 Southeast Missourian, 14 March 1923; Hayti Missouri Herald, 9 March 1923; Dunklin County News, 9 March 1923; New Madrid Weekly Record, 16 March 1923; Charleston Enterprise-Courier, 22 March 1923; St. Louis Star, 15 March 1923.

126 J.W. Timberman to Arthur Hyde, 2 March 1923, Western Union Telegram, Folder 107, AMH, SHS-MO; W.E. Kirkendall to Arthur Hyde, 1 March 1923, Western Union Telegram, Folder 107, AMH, SHSMO; C.D. Jackson to Arthur Hyde, 1 March 1923, Western Union Telegram, Folder 107, AMH, SHS-MO; W.P. Robertson to Arthur Hyde, 2 March 1923, Western Union Telegram, Folder 107, AMH, SHS-MO.

${ }^{127}$ Arthur Hyde to Carl Bloker, 28 February 1923, Western Union Telegram, Folder 107, AMH, SHS-MO; Arthur Hyde to Joe Cash, 28 February 1923, Western Union Telegram, Folder 107, AMH, SHS- 
law enforcement accounts and found that "peace and quiet prevails." 128 C.F. Bloker of Caruthersville, however, offered a different opinion. Bloker acknowledged the intimidation of African Americans in the region and admitted that many people had left Pemiscot County, especially after shootings at several local cabins. "The foundation of the trouble is politics," Bloker told Hyde, "and the situation was created in the last election by getting out KKK notices notifying the negroes that they would not be permitted to vote." It was the "trifling white land tenants," Bloker asserted, that were the driving force behind the violence. ${ }^{129}$ Bloker's claims were supported by Pemiscot County Prosecuting Attorney Shelley Stiles who told the St. Louis Post-Dispatch that white laborers in several cotton belt counties had threatened and assaulted newly arriving African American workers. ${ }^{130}$

Despite assurances from Shelley Stiles that southeast Missouri would not descend into chaos, attacks against African American laborers escalated to the point that Governor Hyde sent members of the state National Guard to New Madrid and Stoddard counties. ${ }^{131}$ Once there, the National Guard found that conditions "warrant temporary protection of a

MO; Arthur Hyde to Simon Loebe, 28 February 1923, Western Union Telegram, Folder 107, AMH, SHSMO; Arthur Hyde to C.F. Bloker, 2 March 1923, Folder 107, AMH, SHS-MO.

128 H.P. Loebe to Arthur Hyde, 1 March 1923, Western Union Telegram, Folder 107, AMH, SHSMO; Joe Cash to Arthur Hyde, 1 March 1923, Western Union Telegram, Folder 107, AMH, SHS-MO.

${ }^{129}$ C.F. Bloker to Arthur Hyde, 1 March 1923, Western Union Telegram, Folder 107, AMH, SHSMO; C.F. Bloker to Arthur Hyde, 1 March 1923, Folder 107, AMH, SHS-MO.

${ }^{130}$ St. Louis Post-Dispatch, 2 March 1923, 3 March 1923.

${ }^{131}$ St. Louis Post-Dispatch, 2 March 1923, 3 March 1923, 23 April 1923; St. Louis Argus, 2 March 1923; Hayti Missouri Herald, 16 March 1923; Stoddard Tribune, 26 April 1923. 
colony of negroes." 132 Tensions were especially high in the towns of Bernie and Parma after Tom Keaton, a local black laborer, was shot to death while asleep in bed. As the National Guard patrolled county roads to dissuade further intimidation and assaults, Herbert Bleese, a former Stoddard County Justice of the Peace, as well as two other men were arrested in connection with Keaton's death. ${ }^{133}$ In a speedy trial, all three were acquitted and the courtroom crowd erupted in cheers upon the reading of the verdict. ${ }^{134}$

As the search for guilty parties continued in the midst of the violence, an alleged sighting of men in black hoods near the site of one of the attacks turned attention towards the Ku Klux Klan. Such accusations were justified considering the earlier "K-K-K" flyers and the Klan's own history of night-riding and intimidation, but the organization, which was just starting to make in-roads around the cotton belt, denied any involvement. The Klan tried to stop the intimidation of black laborers in the cotton belt for two main reasons. First, the organization feared that intimidation would drive out black laborers and negatively impact the local economy. Second, the Klan was trying to repair its image both locally and nationwide. In an effort to separate the organization from the violence, Klansmen from several cotton belt towns warned possible intimidators that "if baiting continues...the klan [sic] will throw back of the law's enforcement the full power of its secret service and extend itself to bring the guilty to justice." ${ }^{" 135}$ With an estimated cotton belt population of close to four thousand, Klansmen certainly felt that they could

132 J.S. Gossom to Arthur Hyde, 24 March 1923, Folder 107, AMH, SHS-MO; A.C. Thrower to Arthur Hyde, 24 April 1923, Folder 107, AMH, SHS-MO; St. Louis Post-Dispatch, 23 April 1923.

${ }^{133}$ St. Louis Post-Dispatch, 24 April 1923.

${ }^{134}$ St. Louis Post-Dispatch, 11 May 1923; Bloomfield Vindicator, 11 May 1923.

${ }^{135}$ St. Louis Post-Dispatch, 10 May 1923. 
influence local residents and stem the tide of violence. ${ }^{136}$ After all, the cotton belt press tended to publish favorable stories about the Klan's philanthropic activities. ${ }^{137}$ Yet despite agreeing with the Klan that intimidation had to stop, the local press, particularly the Charleston Enterprise-Courier and Hayti Missouri Herald, also felt that a close eye needed to be kept on the ever-growing black population.

By all accounts, the violence that plagued southeast Missouri in the spring of 1923 subsided by the summer. While tensions continued, large-scale violence did not return during the fall harvest or the start of the 1924 planting season. For a time, it really seemed that peace and quiet would truly prevail in the region, but political activism and the upcoming 1924 General Election soon brought many issues back to the surface. The fear centered on the idea of "negro supremacy," a term bandied about by the local press suggesting that the large influx of African Americans into the cotton belt would challenge the Democratic Party's stranglehold on the region. While continually questioning the intelligence and mental capacities of the black population, the newspapers stopped short of calling for their disenfranchisement. Nevertheless, the press repeatedly warned white residents of attempts by Republican politicians, federal investigators, and black activists

\footnotetext{
136 St. Louis Post-Dispatch, 11 May 1923; Southeast Missourian, 10 February 1923; C.D. Unsell told the Southeast Missourian that while the Klan was not organized in Cape Girardeau, it did have members in Poplar Bluff, Neelysville, Harviell, Doniphan, Naylor, Piedmont, Williamsville, Puxico, Dexter, Bernie, Bloomfield, Illmo, Fornfelt, Chaffee, Sikeston, Morley, Charleston, Morehouse, Lilbourn, Marston, Parma, New Madrid, Portageville, Gideon, Caruthersville, Hayti, Steele, Campbell, Malden, Kennett, and Senath.

137 Dexter Statesman, 9 February 1923, 23 February 1923, 9 March 1923, 23 March 1923; East Prairie Eagle, 23 February 1923; Malden Merit, 23 March 1923; Charleston Enterprise-Courier, 4 October 1923.
} 
with the UNIA and NAACP to court African American voters and push for social equality. ${ }^{138}$

When questioned on its opposition to black office holding and political activism, the Charleston Enterprise-Courier acknowledged it was a "mercenary in its fight for white supremacy... [because] we must confess a feeling of nausea when we see a white man humbling himself before a negro." ${ }^{139}$ Noting that incoming black laborers deserved adequate accommodations and protection from intimidation, the Enterprise-Courier also warned that "political and social equality must be denied and should not be expected."140 Farther south, the Caruthersville Democrat-Argus called on its readers to monitor the polls because previous elections had been "stolen" by Republicans and illegal black voters. ${ }^{141}$ The Hayti Missouri Herald stoked political fires by alleging that the Republican Party favored "negro equality." 142 The Missouri Herald also lashed out at black voters by implying that they had about as much of a right to vote as "cattle."143 Less than two months after the November 1924 General Election, Roosevelt Grigsby died at the hands of a lynch mob in the cotton belt town of Charleston, Missouri. He had allegedly attacked Elizabeth McFadden, the fifteen year old daughter of

138 Charleston Enterprise-Courier, 18 October 1923, 25 October 1923, 1 November 1923, 29 November 1923, 29 November 1923, 30 October 1924, 6 November 1924, 20 November 1924, 4 December 1924; Caruthersville Democrat-Argus, 31 October 1924, 7 November 1924; Hayti Missouri Herald, 31 October 1924, 14 November 1924, 21 November 1924.

${ }^{139}$ Charleston Enterprise-Courier, 4 December 1924

${ }^{140}$ Charleston Enterprise-Courier, 18 October 1923.

${ }^{141}$ Caruthersville Democrat-Argus, 31 October 1924

142 Hayti Missouri Herald, 31 October 1924.

${ }^{143}$ Hayti Missouri Herald, 7 November 1924. 
prominent local politician George McFadden, during an early evening walk. McFadden asserted that her attacker fled quickly at the sight of an approaching automobile, but locals portrayed the event as more than just a terrifying few moments. ${ }^{144}$ In the face of widespread condemnation, residents of Charleston defensively argued that the lynching was a response to recent violent acts allegedly committed by African Americans, including Grigsby's own history of crimes against women. ${ }^{145}$ "These dastardly crimes," the Enterprise-Courier wrote of the attacks leading up to the lynching, "were indirectly encouraged by white men approaching negroes on terms of equality for their votes."146 The Hayti Missouri Herald compared Grigsby to "the very satanic embodiment of animal lust...[who] had his eyes out for white girls" and felt the lynching justified because "mothers, sisters, wives, daughters and sweethearts [now] were safer."147 When pressed by state officials to conduct a thorough investigation into the lynching, Charleston Mayor C.L. Joslyn told state Attorney General Jesse W. Barrett to "go to hell."148 Though Grigsby died at the hands of "persons unknown to us," some local residents felt his apparent confession was evidence enough for his execution. ${ }^{149}$

\footnotetext{
144 Jefferson City Post-Tribune, 19 December 1924; St. Louis Star, 19 December 1924; St. Louis Post-Dispatch, 19 December 1924; Cape Girardeau Southeast Missourian, 19 December 1924; Sikeston Standard, 23 December 1924; Caruthersville Democrat-Argus, 23 December 1924; Charleston EnterpriseCourier, 25 December 1924; St. Louis Argus, 26 December 1924; Kansas City Call, 26 December 1924; East Prairie Eagle, 26 December 1924; Dexter Statesman, 26 December 1924; Campbell Citizen, 26 December 1924; Bloomfield Vindicator, 26 December 1924; Hayti Missouri Herald, 26 December 1924; Dunklin County News, 26 December 1924.

145 St. Louis Star, 19 December 1924; Sikeston Standard, 23 December 1924.

${ }^{146}$ Charleston Enterprise-Courier, 20 November 1924.

${ }^{147}$ Hayti Missouri Herald, 26 December 1924.

148 St. Louis Star, 30 December 1924.

${ }^{149}$ Sikeston Standard, 23 December 1924.
} 
Grigsby's confession, however, soon turned the events in Charleston into a national story. Many newspapers noted that while police were questioning Grigsby, a piece of paper allegedly containing his confession slipped out of an upstairs window of the courthouse and fell into the hands of mob members. Read aloud, this paper sent the mob into a fury and they soon stormed the courthouse and forcefully removed Grigsby from police custody. ${ }^{150}$ Though mob members did not wear masks, and some even tied up police officers to prevent them from stopping the lynching, law enforcement officials claimed that they could not identify a single person that took Grigsby. ${ }^{151}$ Even the prosecuting attorney, J.C. McDowell, who was in the interrogation room at the time of the mob's entry, told the press that it would be difficult to find the guilty individuals. ${ }^{152}$

Outside of the cotton belt, doubt quickly spread over local officials retelling of events. The New York Age told its readers that local authorities did little to "prevent the action of the mob [or] protect the accused from its violence." ${ }^{153}$ The Pittsburgh Courier called Grigsby the “victim of a mysterious 'confession,' dropped conveniently...to members of the mob." ${ }^{154}$ In Kansas City, Rev. T.J. Moppins declared that "mob murder is now the birth-mark of white America, generations yet unborn will carry this mark of savage brutality upon their brows." ${ }^{155}$ Noting that Grigsby was removed from the

150 Jefferson City Post-Tribune, 19 December 1924; St. Louis Post-Dispatch, 19 December 1924; Pittsburgh Courier, 27 December 1924.

${ }^{151}$ Southeast Missourian, 20 December 1924; St. Louis Star, 19 December 1924.

${ }^{152}$ Sikeston Standard, 23 December 1924.

${ }^{153}$ New York Age, 27 December 1924.

${ }^{154}$ Pittsburgh Courier, 27 December 1924.

${ }^{155}$ Kansas City Call, 26 December 1924. 
courthouse without a shot fired by law enforcement in his protection, the St. Louis Argus condemned Sheriff Jackson for failing to do his duty and wondered aloud if "the State [will] act when the county fails." "If the State fails," the Argus continued, "we must appeal to the United States. If Uncle Sam says his arms are too short, then we wonder what does our allegiance to the flag, the stars and stripes, mean? What does our citizenship mean? To what source shall we look for protection?"156

Governor Hyde soon heard the cry of injustice from the press and the African American community. "12 million Negroes in the United States are praying that you go the fullest extent in the investigation of this lynching," E.C. Branch of New York wrote the governor. ${ }^{157}$ With new governor Sam Baker set to take office in early 1925, however, Hyde was limited in the action he could pursue. He called upon state Attorney General Jesse Barrett to investigate the lynching and offered a \$300 reward for information related to the guilty parties. ${ }^{158}$ It appears that Baker's administration was also aware of the lynching and supportive of Hyde's actions, but with little surviving archival records, it is hard to say how involved Baker was in the impending trial. ${ }^{159}$ Following the state's lead, newly elected Mississippi County Prosecuting Attorney, Lester Cain, promised to aid in the lynching investigation and bring the case to trial. ${ }^{160}$ Yet in the end, the grand

${ }^{156}$ St. Louis Argus, 26 December 1924.

${ }^{157}$ E.C. Branch to Arthur Hyde, 19 December 1924, Folder 109, AMH, SHS-MO; Arthur Hyde to E.C. Branch, 23 December 1924, Folder 109, AMH, SHS-MO.

158 St. Louis Post-Dispatch, 19 December 1924; St. Louis Star, 19 December 1924.

159 Orren Wilson to Arthur Hyde, 22 December 1924, Folder 109, AMH, SHS-MO; Arthur Hyde to Orren Wilson, 24 December 1924, Folder 109, AMH, SHS-MO.

${ }^{160}$ St. Louis Star, 7 January 1925. 
jury called Grigsby’s death “deplorable," but after reviewing the incident, decided not to indict a single person for their role in the lynching. ${ }^{161}$

Lynchings like those of James T. Scott and Roosevelt Grigsby weighed heavily on the minds of African Americans as they left their rural homes for better and seemingly safer opportunities in the North and West. The movement of African Americans out of the South during the Great Migration brought many new inhabitants to Missouri's two principal cities, Kansas City and St. Louis. Between 1910 and 1920, the state's black population increased by $13 \%$ while the cities saw an increase of $30 \%$ and $59 \%$ respectively. ${ }^{162}$ The arrival of increasing numbers of African Americans brought a surge in demand for housing, employment, education, and healthcare. In Kansas City and St. Louis, a residential boom led to an overcrowding in the cities' predominantly African American neighborhoods. To escape these miserable conditions, middle class blacks sought out new accommodations in neighboring white communities. Through the work of local realtors, many using scare tactics such as lower property value and the inability to sell, entire blocks were "busted" to accommodate this movement. The end result was an expansion of black neighborhoods to ease overcrowding, but home ownership came with an inflated price tag. Additionally, the newly opened neighborhoods quickly resegregated as whites moved out. ${ }^{163}$

${ }^{161}$ Southeast Missourian, 27 February 1925.

162 U.S. Bureau of the Census, Thirteenth Census of the United States: 1910, vol. 2: Population, 1101-1122; U.S. Bureau of the Census, Fourteenth Census of the United States: 1920, vol. 2: Population, 551-562.

163 Schirmer, A City Divided, 99-101. 
To combat a "Negro invasion" into predominately white neighborhoods, white residents of Kansas City and St. Louis formed "improvement" or "protective" associations. With names like the Southeast Home Protective Association, Linwood Improvement Association, Finney and Cook Improvement Association, Wagoner Place Improvement Association, Marcus Avenue Improvement Association, and United Welfare Association, these groups concealed their true goal - keeping undesirable homeowners out - behind a call for community betterment. ${ }^{164}$ Backed by these improvement associations, the St. Louis Real Estate Exchange had successfully pushed for a zoning ordinance banning blacks from purchasing homes in blocks or neighborhoods that were more than seventy-five percent white. Passed by popular vote over the opposition of Mayor Henry Kiel, Congressman L.C. Dyer, and the NAACP, the new ordinance eventually was struck down after the United States Supreme Court declared a similar Louisville, Kentucky, law unconstitutional in Buchanan v. Warley (1917). ${ }^{165}$

In addition to improvement associations, local white neighborhoods also used race-restrictive covenants to prevent integration. Generally, these restrictive covenants bound homeowners to a specific set of rules regarding home construction, neighborhood development, and sale/rental options. By stressing uniformity, these restrictive covenants allowed developers to predetermine what characteristics the homeowners would embody.

\footnotetext{
164 Schirmer, A City Divided, 109-121; Colin Gordon, Mapping Decline: St. Louis and the Fate of the American City (Philadelphia: University of Pennsylvania Press, 2008), 69-83.

165 Gordon, Mapping Decline, 70-71; Primm, Lion of the Valley, 410-414; Eric Sandweiss, St. Louis: The Evolution of an American Urban Landscape (Philadelphia: Temple University Press, 2001), 210-212; Priscilla A. Dowden-White, Groping Toward Democracy: African American Social Welfare Reform in St. Louis, 1910-1949 (Columbia: University of Missouri Press, 2011), 3-7, 33-35.
} 
As historian Colin Gordon has noted, the defeat of the 1916 segregation ordinance brought about a dramatic increase in restrictive covenants in St. Louis. ${ }^{166}$ Over in Kansas City, two of the city's largest developers, E.H. Bouton and J.C. Nichols, included racerestrictive covenants in many of their planned neighborhoods. Bouton and Nichols were also among a group of developers who initially opposed selling homes to Jews, though this position lessened through the 1920s. ${ }^{167}$ Though not always successful, especially when homeowners did not abide by the deed and zoning restrictions, restrictive covenants proved to be a longstanding deterrent to neighborhood integration. In 1948, the United States Supreme Court ruled in the St. Louis-based Shelley v. Kraemer decision that state courts could not enforce race-restrictive covenants. As this allowed many covenants to remain in place, the ruling slowed, but did not end, the push for similar restrictive covenants, and realtors and homeowners continued the practice into the late $20^{\text {th }}$ century. ${ }^{168}$

With improvement associations and restrictive covenants came more malicious attempts to prevent neighborhood integration. Between the end of World War I and the start of the Great Depression, Kansas City witnessed a series of bombings aimed at African American home owners. After three homes were bombed in the first two months of 1923, the Kansas City Call reminded its readers that "foxes have their holes and the birds their nests, but wherever the Negroes of Kansas City try to get a home, they are met

166 Gordon, Mapping Decline, 71-83.

${ }^{167}$ William S. Worley, J.C. Nichols and the Shaping of Kansas City: Innovation in Planned Residential Communities (Columbia: University of Missouri Press, 1990), 144-155; Schirmer, A City Divided, 107-109.

168 Gordon, Mapping Decline, 81-84. 
with resistance."169 A black World War I veteran compared living in his home to "a repetition of what he went through in No Man's Land."170 Following a bombing in the College Hill neighborhood, the Call lamented that "Improvement Associations and bombing $[\mathrm{s}]$ arrived together...they are anti-Negro far more than they are proanything."171 This sentiment was shared by members of the local branch of the NAACP who wrote to Robert Bagnall in New York City to discuss how improvement associations and recent bombings had impeded the expansion of black home ownership. ${ }^{172}$ While it seemed that these bombings were directed at blacks who were the first to breach the walls of white suburbia, Sherry Lamb Schirmer argues that African Americans "had lived in the troubled areas undisturbed for a number of years before the trouble began."173 Thanks to a construction boom after World War I, Kansas City did not witness the level of racial violence as cities dealing with housing shortages during the 1920s. Instead, threats and bombings occurred in areas where whites experienced apprehension over their new neighbors and concern about the possible "transient" reputation of their neighborhoods. ${ }^{174}$

${ }^{169}$ Kansas City Call, 23 February 1923.

${ }^{170}$ Kansas City Call, 29 April 1922.

${ }^{171}$ Kansas City Call, 19 January 1923.

172 Myrtle Cook to Robert Bagnall, 23 February 1923, Folder 23, Box 1: G107, NAACP, LOC. The Kansas City Branch of the NAACP and the National Branch in New York City kept up a steady correspondence regarding home bombings and segregation throughout the 1920s. For documents on these subjects see Myrtle Cook to Robert Bagnall, 19 June 1924, Folder 24, Box 1: G107, NAACP, LOC; John Love to Walter White, 14 May 1925, Folder 25, Box 1: G107, NAACP, LOC; N.A.A.C.P. Press Release, 27 August 1926, Folder 29, Box 1: G107, NAACP, LOC; Clipping of Kansas City Times, 23 September 1927, Folder 30, Box 1: G107, NAACP, LOC; John Love to James Weldon Johnson, 18 March 1928, Folder 30, Box 1: G107, NAACP, LOC.

${ }^{173}$ Schirmer, A City Divided, 106.

${ }^{174}$ Schirmer, A City Divided, 105-107. 
Nevertheless, the proximity of Ku Klux Klan activity influenced and emboldened the explosive nature of Kansas City's racial geography. As has been shown in previous chapters, the Klan claimed high membership numbers in the city and claimed to hold some sway over the local Republican Party. Kansas City was also the site of the Klan's national klonvokation in 1924. ${ }^{175}$ While not every Klansmen participated in home bombings nor every protective association served as a front for the Invisible Empire, there is some possible overlap between them. When George McClellan sold a property to a local black woman, the real estate agent received a letter, allegedly signed "K.K.K.," threatening to dynamite his office and warning him that "you are on the list for a tarring and feathering on account of your action of locating colored people in white neighborhoods." 176

While not experiencing the same level of violence as their urban neighbors, residents of Clay, Ray, and Lafayette counties, which all bordered Kansas City and Jackson County, also were aware of local Klan activity. Like their fellow members in Little Dixie and the Cotton Belt, Klansmen scoured Kansas City and neighboring counties in the spring and summer of 1923 in search of new recruits. As a young eastern district judge in Jackson County, Harry S. Truman learned early in his political career just how potent the Klan was in the region. Initially flirting with the hooded order in 1922 , Truman ultimately rejected the Klan in favor of Tom Pendergast and won in his first election. Rallying against Truman despite his clean record, the Klan returned in 1924 and

\footnotetext{
175 Knights of the Ku Klux Klan, Inc., Proceedings of the Second Imperial Klonvokation: Held in Kansas City, Missouri, Sept. 23, 24, 25 and 26, 1924 (n.p., n.d.).

${ }^{176}$ Kansas City Call, 17 June 1922.
} 
helped defeat him in his re-election bid. When Truman ran once more in 1926, the Klan offered little resistance and the future president easily won election as presiding judge. ${ }^{177}$ Despite its success in giving hell to Harry Truman, the Klan found itself attached once more to violence in western Missouri. In August 1925, Walter Mitchell, a young African American laborer, was lynched near Excelsior Springs in Clay County, roughly thirty miles northeast of Kansas City. Mitchell had been arrested only hours prior for his alleged involvement in the assault of a white couple while they rode in an automobile. After encircling the jail and awaiting word on Mitchell's confession, a large mob broke into the complex and grabbed him. The mob marched Mitchell through the resort town before being led to a large tree near the edge of town. The mob and a group of onlookers grew so large that they caused a passing train to stop, thus forcing all onboard to witness Mitchell's lynching. ${ }^{178}$ Norman E. Cresswell, a journalist for the Kansas City JournalPost, managed to snap a photograph of Mitchell's last moments as the mob watched him struggle for life. Mitchell died soon after. ${ }^{179}$

When asked by the press about the prospects of an investigation of the lynching, Prosecutor Ray Cummins dismissed the need for such proceedings and noted that justice had been served. ${ }^{180}$ Cummins' words, along with the inaction of other local officials,

177 David McCullough, Truman (New York: Simon \& Schuster, 1992), 141-173; Alfred Steinberg, The Man from Missouri: the Life and Times of Harry S. Truman (New York: Putnam, 1962), 59-64; Roy Jenkins, Truman (New York: Harper \& Row, 1986), 20-21; Robert H. Ferrell, Harry S. Truman: A Life (Columbia: University of Missouri Press, 1994), 95-97.

${ }^{178}$ Kansas City Star, 8 August 1925; Kansas City Journal, 8 August 1925; St. Louis Post-Dispatch, 8 August 1925; St. Louis Star, 8 August 1925.

${ }^{179}$ Kansas City Journal, 8 August 1925.

180 Kansas City Star, 8 August 1925; Kansas City Journal, 8 August 1925; St. Louis Post-Dispatch, 8 August 1925; St. Louis Star, 8 August 1925. 
caused outrage, particularly in the African Americans community of nearby Kansas City. The Kansas City Call expressed utter disgust over the lynching, and proclaimed that "Christ was given a legal trial before crucifixion, but Christians in Missouri will not give a legal trial to a Negro accused of rape."181 The newspaper argued that Mitchell's death was not from rape allegations, but because he had a feud with the man in the automobile over his role in recent cattle thefts. ${ }^{182}$ Robert Cobb of the Missouri Negro Industrial Commission called for the creation of a state-wide inter-racial commission aimed at preventing anti-black violence. ${ }^{183}$ Letters soon flowed into Governor Sam Baker's Jefferson City office, particularly from NAACP members, demanding action by him to bring mob members to justice. ${ }^{184}$ The NAACP followed this up with a national campaign aimed at drawing attention to the lynching. ${ }^{185}$ Baker eventually stepped in and ordered Attorney General Robert Otto to aid Clay County law enforcement in the investigation. ${ }^{186}$ The state's involvement in the matter did little to procure indictments. Less than two weeks after Walter Mitchell's death, a local grand jury was dismissed after it was unable to identify a single mob member. ${ }^{187}$

\footnotetext{
${ }^{181}$ Kansas City Call, 14 August 1925.

182 Kansas City Call, 14 August 1925.

183 Jefferson City Daily Capital News, 20 August 1925.

${ }^{184}$ St. Louis Post-Dispatch, 8 August 1925; St. Louis Star, 8 August 1925.

${ }^{185}$ For information on the NAACP's campaign to bring awareness to the Mitchell lynching see

186 Kansas City Star, 9 August 1925, 10 August 1925; Kansas City Journal, 9 August 1925, 10 August 1925; St. Louis Post-Dispatch, 9 August 1925, 10 August 1925; St. Louis Star, 10 August 1925.

${ }^{187}$ Kansas City Journal, 16 August 1925; Kansas City Call, 21 August 1925; St. Louis Post-Dispatch,
} Folders 16-18, Box C-361, NAACP, LOC. 21 August 1925. 
While the Call ran a minor headline suggesting that Klansmen were involved with the lynching, and later compared the mob's actions to those of Klan atrocities in Texas, there is no clear evidence that the hooded order sanctioned or participated in Mitchell's death. ${ }^{188}$ However, the specter of the Klan hung over the incident largely because articles on the Mitchell lynching shared the pages of newspaper with stories about the organization's well publicized parade in Washington D.C. ${ }^{189}$ As such, it was easy to link the two events. Additionally, the Klan had experienced recruiting and political success in Excelsior Springs prior to the lynching. ${ }^{190}$ As early as 1923, the Missouri Valley Independent noted that the hooded order was quite active in Clay County, especially Excelsior Springs. ${ }^{191}$ Less than a year after the Mitchell's death, Klan officials, perhaps not concerned about any attachment to the incident, selected the small resort town as one of the locations for a series of statewide provincial meetings. ${ }^{192}$ Yet, as will be noted in Chapter 6, the Klan was a shell of its former self in the state by the time of the Mitchell lynching. Plagued by scandals separate from accusations of vigilantism, the hooded order struggled to successfully recruit new members and retain old ones. Just like the lynchings and violence surrounding the deaths of James T. Scott and Roosevelt Grigsby, the Klan garnered only negative attention for its proximity to Walter Mitchell's death.

\footnotetext{
188 Kansas City Call, 14 August 1925.

189 Kansas City Star, 8 August 1925; Kansas City Journal, 9 August 1925.

190 Kansas City Times, 2 April 1924; Missouri Valley Independent, 23 April 1925.

${ }^{191}$ Missouri Valley Independent, 13 February 1923.

192 Missouri Valley Independent, 17 June 1926.
} 
Despite repeated attempts to distance the organization from the violence that swept Missouri during the 1920s, the Ku Klux Klan found that any and all acts of localized terrorism were immediately attached to it. Nevertheless, the Klan still proudly claimed that nearly all of Missouri was now part of the Invisible Empire by the middle point of the decade. Such a declaration was not entirely accurate, as quite a few communities still actively worked to prevent Klan events within their city limits. However, the organization had grown substantially since it first arrived in the state in 1921. In championing the continued need for law and order, community reform, and One Hundred Percent Americanism, Klan officials, under the guidance of new Imperial Wizard Hiram Evans, made it clear that the future of the order lay in politics, not moral vigilantism. Yet, as Missouri Klansmen weighed the benefits of political activism with the negative reputation given the organization during the state's wave of violence; the St. Louis Post-Dispatch warned its readers that "it will be well for Missourians to take seriously the announced intention of the leaders of the Ku Klux Klan to enter state politics." With the Election of 1924 only months away, the voters of Missouri had an important decision to make. Would the state be run by honest and "visible" government, or would the assumed strength of anti-Klanism be trumped by a growing demand for the Invisible Empire. 


\section{Chapter 5: "Vote for Visible Government"}

With two weeks to go until Election Day, W.F. Phares, chairman of the Missouri Republican State Committee, went public with incriminating evidence against Democratic gubernatorial candidate A.W. Nelson. According to Phares, Nelson had allegedly joined the Ku Klux Klan in June 1923 and was hiding his membership to dupe voters. To verify his statement, Phares presented two affidavits to the St. Louis GlobeDemocrat. The first affidavit, signed by B.L. Morris and F.A. Collins, claimed that Nelson's name appeared in a Klan record book in Tipton, Missouri. The second affidavit, signed by C.S. Burns, alleged that Burns had seen Nelson at a Klan event in California, Missouri, and watched as the candidate was initiated into the Invisible Empire. ${ }^{1}$ In laying the affidavits before the eyes of Missouri voters, Phares sent shockwaves through the state and the Democratic Party. His statement reminded voters that "both the Republican and Democratic state convention[s] of Missouri have incorporated in their platform a declaration denouncing the Ku Klux Klan as unAmerican, unpatriotic, and opposed to the constitution.",2

With his campaign thrown into shambles, A.W. Nelson and his advisors offered a quick rebuttal to Phares' claims. While on a campaign stop, Nelson issued a statement denying any affiliation with the Ku Klux Klan. The affidavits, Nelson asserted, were the culmination of a whispering campaign aimed at discrediting him. "I know that I have never received any communication from the klan [sic], never have joined it, never made

\footnotetext{
${ }^{1}$ St. Louis Globe-Democrat, 21 October 1924; St. Louis Post-Dispatch, 21 October 1924.

2 Jefferson City Daily Capital News, October 21, 1924.
} 
application to join it and never paid any initiation fee, dues or anything of the kind," Nelson told the press. Yet in trying to defend himself, Nelson revealed information that would haunt him until Election Day. While brushing aside the comment that his name appeared in a Klan book, Nelson did admit meeting C.S. Burns during a business trip to California in 1923, though he felt that Burns was "honestly mistaken or is maliciously making a misstatement" in his affidavit. According to the candidate, he had only signed a card to gain admittance to the Klan event and left the rally before any official ceremonies took place. He had simply been a "curious and interested spectator."3

The Klan "issue" was the most important element in Missouri politics in 1924. In fact, no other issue dominated the attention of politicians, the press, and voters like the Ku Klux Klan. Despite attempts by political candidates, and some newspaper editors, to shift the focus to subjects like taxation, corruption, agriculture, and the legacy of outgoing governor Arthur Hyde's administration, the Klan issue always returned, time and again, to the forefront. At its core, the Klan issue centered on political candidates and their relationship or affiliation with the Invisible Empire. For some, just being a "preferred" candidate of the Klan was enough to boost a campaign at the local level. For others, even the smallest rumors of Klan support had to be squelched through public denunciations of the hooded order. Still others gave only passing reference to the Invisible Empire in the hopes that both Klan and anti-Klan voters would carry them

\footnotetext{
${ }^{3}$ Kansas City Post-Journal, October 22, 1924; Kansas City Star, October 22, 1924; St. Louis PostDispatch, October 21, 1924; St. Louis Globe Democrat, October 22, 1924. In addition to being at the California Klan rally, Nelson also admitted that he had been at the 1923 Southwest Missouri Fair in Jasper County when "several automobiles containing persons in klan [sic] costumes drive [sic] around the racetrack and then drove on out."
} 
through on Election Day. With the Ku Klux Klan publicly announcing the candidates it supported, and the anti-Klan press ratcheting up its attention on the hooded sentiments of select politicians, candidates, from the municipal to the state level, quickly realized that their campaigns needed to address the subject of the Invisible Empire. To win, prospective candidates for political office had to answer a simple, yet fundamentally difficult, question posed to them by voters, newspaper editors, Klansmen and - women, anti-Klan activists, and even their own fellow politicians: Do you support "visible" government or the Invisible Empire?

This chapter follows the trajectory of the Klan issue from municipal contests in Buchanan and Jasper counties - two strongholds of the hooded order - through the primary and general elections of 1924. In examining the Klan's involvement in state politics, I argue that anti-Klan activists tried to turn voters against the hooded order by casting the year's elections as a conflict between visible/honest (anti-Klan) governments and invisible/corrupt (Klan) governments. Such attempts met with mixed success as communities like Joplin, Carthage, and St. Joseph still voted overwhelmingly for Klanbacked candidates, and both the state Republican and Democratic parties refused to openly condemn the hooded order in their conventions. However, Klan-backed candidates experienced rejection by voters in many state-level races, particularly the gubernatorial campaign between Sam A. Baker and A.W. Nelson. In what would become an especially heated race, a series of affidavits released by Republicans claiming he was a secret member of the Klan ultimately doomed the campaign of Democrat A.W. Nelson. Though he denied these claims, Nelson was unable to convince voters that he had no white robes in his political closet. 
In addition to analyzing the Klan issue in Missouri politics in 1924, I also argue that the hooded order emerged from the year's elections fractured. While the Klan would not decline nationwide until 1925, this deterioration developed out of the organization's results at the ballot box in 1924. As scholars such as Thomas Pegram, Rory McVeigh, David Chalmers, and Nancy MacLean argue, the Klan's electoral failures in 1924, combined with its lackluster handling of governmental affairs in the communities it already controlled, produced resentment among frustrated members. ${ }^{4}$ These failures also contributed to a growing resurgence of anti-Klan strength, particularly in southwestern Missouri communities like Joplin and Carthage where the Klan had grown especially robust by the mid-1920s. The eventual decline of the Klan is the focus of Chapter 6, but it is important to note the growing dissatisfaction among Missouri Klan members during and immediately after the 1924 elections. Not only was the state Klan unable to convince voters that the organization's ideologies and reform goals were essential for the management of local government, but its heavy handed approach in recommending that members back specific candidates brought resentment from Klansmen and -women who felt a loss of individual autonomy under politically motivated state and national leadership.

In Missouri, the question of "visible" versus "invisible" government first emerged in Jasper County. While the Jasper County Bar Association had been somewhat successful in denouncing the Klan in 1923, local sentiment still leaned favorably towards the Invisible Empire, especially within the administration of Joplin mayor Taylor Snapp.

\footnotetext{
${ }^{4}$ Pegram, One Hundred Percent American, 185-216; Rory McVeigh, The Rise of the Ku Klux Klan: Right-Wing Movements and National Politics (Minneapolis: University of Minnesota Press, 2009), 180193; Chalmers, Hooded Americanism, 291-299; MacLean, Behind the Mask of Chivalry, 177-188.
} 
With municipal elections approaching in the spring of 1924, Jasper County's anti-Klan supporters felt it necessary to alert the voting public to the dangers of hooded rule. Under the guidance of local attorney George Grayston, the Joplin Anti-Klan Organization (JAKO) quickly formed with the intention of supporting candidates in the municipal election, particularly for Public Property and Public Utilities Commissioner, Health and Sanitation Commissioner, and local school boards. ${ }^{5}$ Though members of JAKO did not specify why they targeted these commissioner positions, their reasoning is quite clear as both incumbents, J.M. Lane and Dr. M.B. Harutun, were rumored to be Klansmen because of their prior comments supporting the organization's reform goals. ${ }^{6}$ If it could not get either man to admit their Klan-ties, JAKO hoped to at least pressure other municipal and county candidates into making statements regarding the Invisible Empire.

The chief concern of the Joplin Anti-Klan Organization was that voters were unknowingly casting ballots for candidates who were sympathetic to the Klan. By making these possible ties visible, the organization hoped that local voters would repudiate the Invisible Empire. JAKO soon launched an advertising campaign in the Joplin Globe and Joplin News-Herald to make local residents aware of the secrecy of the Klan and imploring them to register to vote. The group reminded voters that the "AntiKlan Organization wants not only good men to govern our city, but wants free men, men who will counsel with all good citizens irrespective of race, creed or color..." "Men," the statement continued, "whose course will not be determined by the prejudiced edict... of some secret organization, who meet in the dark hours of the night and who

\footnotetext{
${ }^{5}$ Joplin Globe, 15 March 1924, 18 March 1924.

${ }^{6}$ Joplin News-Herald, 18 October 1921.
} 
attempt to hide their identity during the day."7 In its other ads, JAKO discussed "atrocities," "criminal Klan leaders," and how the "Cross of Jesus Christ Is Not a Fiery

Cross." 8 In placing before potential voters a long list of accusations against the Klan, the goal was simple. As one JAKO member put it, "We will tear off this mask of secrecy and make candidates come out in the open and state their stand."9

With municipal primaries fast approaching, George Grayston, with the support of JAKO, publicly released a list of preferred candidates. To counter J.M. Lane as Commissioner of Public Property and Public Utilities, JAKO backed L.L. Travis and R.P. Brown. In the race for Commissioner of Health and Sanitation, Dr. W.H. Lanyon and W.E. Pierson received JAKO support. ${ }^{10}$ JAKO's backing of two candidates for each commissioner position was an interesting choice, though it is likely that the relatively new group did not want to alienate potential supporters. George Grayston indicated as much when he argued that JAKO did not center votes on a particularly anti-Klan candidate because "it would have been unfair to have discriminated between good men who had the courage... to challenge the klan's [sic] control of the city." "11 Yet, it seems obvious that JAKO hoped that one of its candidates would have a strong enough showing to earn a place on the April ballot. With a heavier than usual vote expected, there was much to be won by the up-and-coming JAKO.

\footnotetext{
7 Joplin Globe, 25 March 1924.

8 Joplin Globe, 20 March 1924, 21 March 1924, 23 March 1924, 26 March 1924, 28 March 1924, 29 March 1924, 30 March 1924; Joplin News-Herald, 20 March 1924, 26 March 1924, 29 March 1924.

${ }^{9}$ Joplin Globe, 15 March 1924.

10 Joplin Globe, 18 March 1924; Joplin News-Herald, 18 March 1924.

11 Joplin Globe, 19 March 1924.
} 
As the primary results came in for both parties, it quickly became obvious that Lane and Harutun had sizable leads in their respective races. But, JAKO still claimed victory after Travis and Lanyon finished second in their races guaranteeing them a spot on the final ballot. Interestingly, in a public statement after the election, George Grayston indicated that JAKO would back Travis for Commissioner of Public Property and Public Utilities over Lane, but the organization had no preference between Harutun and Lanyon. Despite allegations of Klan ties with Harutun, JAKO felt confident that he was not a Klansman. ${ }^{12}$ As for the race between J.M. Lane and L.L. Travis, Grayston did not mince words:

An analysis of the vote gives every reason for encouragement to those opposed to secret government. Three out of the four men nominated are positively not Klansmen. Mr. Lane got the klan [sic] vote...As to Mr. Travis, he makes no concealment of the fact that he is not a member of the Ku Klux Klan. For this reason, in the coming election, Mr. Travis will receive the almost unanimous support of Joplin citizens actively opposed to the klan [sic]. Not only will he receive strong support because he is not a member of the klan [sic], but also because he is a strong man of high character, a resident of Joplin for twenty-nine years and well-fitted to fill the office of commissioner of public property and public utilities...Many citizens believe that his election will do much to abolish secret government in our city and tend to remove the distrust and bitterness that the klan [sic] movement has engendered in our churches, our schools, our lodges and our civic organizations and even our business life. A vote for Mr. Travis means a vote for harmony among our citizens; a vote for him means lighted streets all night; a vote for him means a vote for city government

\footnotetext{
12 Joplin Globe, 19 March 1924. A few days before the municipal election, M.B. Harutun issued a public statement in both the Joplin Globe and Joplin News-Herald denying that he was a Klansman or that he had been solicited by the Klan. Harutun cited that even if he wanted to join the Klan he could not because of his foreign birth. For Harutun's official statement see Joplin Globe, 30 March 1924, and Joplin News-Herald, 31 March 1924. For a letter inquiring about Harutun's stance on the Klan see George Grayston to M.B. Harutun, 25 March 1924, Folder 15, Perl D. Decker Papers, State Historical Society of Missouri, Columbia, Missouri.
} 
conducted in the open light of the council chambers and not in a klavern. ${ }^{13}$

Joplin was not the only Jasper County community engulfed in the Klan/anti-Klan war. In nearby Carthage, Klan support from both Democrats and Republicans led antiKlan backers to hastily consider forming a third party group. Led by Judge Howard Gray, Allen McReynolds, and former Klansman Harry Mead, the Carthage Anti-Klan Association (CAKA) formed soon after JAKO. Though both groups were not directly connected, they did share a common concern: if Klansmen or their sympathizers are on the ballot, they must be defeated. Due to its late formation, CAKA was unable to place candidates on the ballot for the municipal election. Instead, the organization endorsed an unofficial ticket comprised of candidates from both parties. The most prominent name on the list was Charles Drake, Carthage's Democrat mayor. ${ }^{14}$

By the end of March, the respective anti-Klan groups in Joplin and Carthage moved towards becoming a truly county-wide organization. Only days before the municipal elections in both towns, the organizations decided to hold mass rallies in each community. To build towards both events, JAKO and CAKA inundated the Joplin Globe, Joplin New-Herald, and Carthage Evening Press with daily reminders of the threat posed by a Klan government. ${ }^{15}$ "We charge that our liberties are endangered, our

\footnotetext{
13 Joplin Globe, 19 March 1924.

14 Joplin Globe, 18 March 1924, 19 March 1924, 21 March 1924, 25 March 1924, 26 March 1924; Joplin News-Herald, 19 March 1924, 26 March 1924; Carthage Evening Press, 18 March 1924, 24 March 1924, 27 March 1924; Jasper County Democrat, 21 March 1924.

15 Joplin Globe, 20 March 1924, 21 March 1924, 23 March 1924, 25 March 1924, 26 March 1924, 28 March 1924, 29 March 1924, 30 March 1924; Joplin News-Herald, 20 March 1924, 26 March 1924, 29 March 1924; Carthage Evening Press, 28 March 1924, 29 March 1924, 31 March 1924.
} 
institutions are threatened, our citizens are intimidated," JAKO warned potential voters, "there is no longer an open and free discussion of the affairs of our City Government or of the conduct of the administration of our public schools." ${ }^{16}$ If residents were concerned about these issues, JAKO advised them to attend an upcoming meeting at the New Joplin Theater. This meeting was opened to all residents to ensure "that there may be an intelligent decision by the voters of this city in the coming city election as to whether you prefer to have your city governed from the city hall or from the cave (Klavern) in Belleville."17

When the night of the big anti-Klan rally arrived, a large overflow crowd filled the theater. "I thank you for coming here, members of Ozark Klan No. 3," Perl Decker told the occupants of the front row as he opened his JAKO speech, "I much prefer to address you here than at your cave at Belleville." ${ }^{18}$ Decker, and the other speakers, knew the Klan had not-so-secretly infiltrated the meeting, but they cared little as each man took his turn denouncing the Klan and ridiculing those that wore "sheets over their bodies and pillowslips over their heads." ${ }^{19}$ Though the list of speakers featured prominent men from throughout Jasper County, the main draw was Perl Decker. Decker, an ardent Prohibitionist and former United States Representative from Missouri, had lived most of his life in Joplin and watched as the city slowly descended into the Invisible Empire. He was aware of the activities of JAKO, and his personal records indicate that he worked

\footnotetext{
${ }^{16}$ Joplin Globe, 28 March 1924.

${ }^{17}$ Joplin Globe, 21 March 1924.

18 Joplin Globe, 27 March 1924.

${ }^{19}$ Joplin Globe, 27 March 1924.
} 
behind the scenes for the organization. ${ }^{20}$ Now on stage in front of eighteen hundred Jasper County residents, Decker tore the Klan apart.

The central theme of Decker's speech was the role of the American citizen in denouncing religious intolerance. But time and again, Decker came back to the subject of secrecy. "Secret lobbies, secret organizations, secret influences have always been the cause of debauchery and corruption in American politics," Decker told the audience, "[i]f [the Klan] had their way the real course of our national congress and our state legislature and our school managers would be guided by the prejudiced edict of the head of their secret organization." ${ }^{21}$ He presented dark scenarios to his listeners where Joplin's affairs were discussed and decided upon not in city hall, but at the Klan's cave at Belleville - an example not too far off from reality in Jasper County. "Why should high-minded citizens of Joplin... appear before our city commission or before our school board," Decker pondered, "if the course has already been shaped and determined by the meeting of a secret organization." 22

After warning the crowd about the dangers of hooded politics, Decker next discussed the Klan's violent legacy. From Mer Rouge to Herrin, Decker laid out examples of moral vigilantism tied to the Klan. Perhaps, Decker argued, Klansmen had not undertaken these actions, but with such secrecy surrounding the organization there was no way to know for sure. Finally, Decker gave the audience and the Klansmen in

${ }^{20}$ Decker's personal papers contain a folder consisting of undated and untitled drafts of anti-Klan speeches and JAKO advertisements submitted to local newspapers. For this information see Folder 15, Perl D. Decker Papers, State Historical Society of Missouri, Columbia, Missouri.

${ }^{21}$ Joplin Globe, 27 March 1924.

22 Joplin Globe, 27 March 1924. 
attendance a history lesson. He told his listeners of the American presidents who had denounced religious intolerance. He spoke of the Catholic and Jewish soldiers of long forgotten wars who defended their country despite bigotry against them. He closed with a reminder about the price paid by all Americans to ensure liberty and freedom for their fellow citizens:

If these boys, Jew and gentile and Protestant and Catholic could fight and die in time of war for that flag we love, can not we who are Protestants stand up like men, even at the risk of losing a little business, even at the risk of losing a little popularity, can we not stand up to fight to see that these Jewish boys and these Catholic boys and their fathers and their mothers, and their sisters and their brothers have the full enjoyment of the blessings and privileges emblemized by that flag for which they fought and died? ${ }^{23}$

With the meeting concluded, the message was as clear as the banners hanging in the New Joplin Theater: "Vote for Visible Government". While the residents of Joplin considered JAKO's warning regarding the role of the Invisible Empire in their civic affairs, CAKA held its own rally in nearby Carthage. Smaller in size than the one in Joplin, the Carthage meeting, featuring Allen McReynolds and Howard Gray as the main speakers, filled every available space in the city's circuit court with the crowd crammed into adjacent hallways. McReynolds, a native of Carthage, denounced recent attempts by the Klan to donate Bibles to area public schools. Speaking on religious intolerance, he reminded the audience of the anti-Catholicism of past generations where "I was taught to believe the basement of every Catholic church in this country was filled with guns and ammunition and that at the word of the pope the Catholics would take up arms against

\footnotetext{
${ }^{23}$ Joplin Globe, 27 March 1924.
} 
this country." 24 The theme of past intolerance continued with Howard Gray who told the audience that the Klan reminded him of the American Protective Association. He assured those in attendance that the Klan would meet a similar fate as the A.P.A. because it was “organized for personal gain" with a membership comprised of people "duped into believing it an organization of Americans."25

After nearly two weeks' worth of charges and attacks directed at it, Ozark Klan No. 3 took out ads in the Joplin Globe and Joplin News-Herald to defend the Invisible Empire. "Be Not Deceived," the local order warned voters, "any statement to the effect that the Ku Klux Klan controls or dominates the Joplin city administration, or that it is attempting to do so, is an absolute lie!"26 To charges that it met in darkness and secrecy, the Klan pointed out that the Knights of Columbus, B’Nai B'Rith, Odd Fellows, Masons, and even the city's own Anti-Klan Organization held similar secret meetings. According to the Klan, the real question surrounding the election was simple: "Do you want clean, efficient government by clean officials, qualified by ability to perform their duties to all the people, or a government by officials put forward through swapping of political favors and pre-election promises, or by those whose qualifications are that they need the money?"27

24 Joplin Globe, 29 March 1924; Joplin News-Herald, 29 March 1924; Carthage Evening Press, 29 March 1924.

25 Joplin Globe, 29 March 1924; Joplin News-Herald, 29 March 1924; Carthage Evening Press, 29 March 1924.

${ }^{26}$ Joplin Globe, 30 March 1924; Joplin News-Herald, 31 March 1924.

27 Joplin Globe, 30 March 1924; Joplin News-Herald, 31 March 1924. 
The growing tension between Klan/anti-Klan factions was not lost on the editors of the Carthage Evening Press and the Joplin Globe who feared that party allegiance and straight ticket politics would dissolve in the fray. The Evening Press, though an ardent opponent of the Klan, felt that "there are bigger things than the Ku Klux Klan...[and] the Republican party is one of them." Warning its readers against joining any third party organized by anti-Klan supporters, the Evening Press instead advised Republicans to support the party's candidates based on their personal merits "regardless of their Klan or anti-Klan affiliations." 28 Though not as partisan in its response as the Evening Press, the Globe hoped for a positive outcome in the election. Amidst ads for both the Ku Klux Klan and JAKO in its March $30^{\text {th }}$ edition, the Globe posited that "if the fight for and against the Ku Klux Klan in Joplin results in getting a good vote out at the annual city election day after tomorrow it will at least have accomplished some good."29

April $1^{\text {st }}$, Election Day, saw a heavy turnout throughout Jasper County. Though it had existed for only a short time, JAKO was confident in its campaign and felt sure that voters would prefer "visible" government to the Invisible Empire. Yet, when the returns came in, it soon became clear that the Ku Klux Klan still controlled large portions of Jasper County. In Joplin, Klan-backed candidates swept the municipal election. Up in Carthage, the preferred candidates of CAKA were defeated as well. ${ }^{30}$ Though they had championed a message of liberty, tolerance, and uncorrupted government, the failure of both anti-Klan groups lay in their organization. While their membership included

${ }^{28}$ Carthage Evening Press, 18 March 1924.

${ }^{29}$ Joplin Globe, 30 March 1924.

${ }^{30}$ Joplin Globe, 2 April 1924; Joplin News-Herald, 2 April 1924; Carthage Evening Press, 2 April 1924. 
individuals who had denounced the Klan at the January 1923 Jasper County Bar Association meeting, there was no clear attempt to build upon this sentiment and establish an official anti-Klan organization until 1924. By the time JAKO and CAKA went public, there was less than a month until Election Day, insufficient time to mount a serious challenge to a well-entrenched Klan operation.

However, while events looked grim in Joplin and Carthage, other parts of southern Missouri leaned towards anti-Klan sentiments. Webb City, located between Joplin and Carthage, experienced no major factionalism over the Klan in its municipal election. ${ }^{31}$ The residents of Waco, a tiny community in northwestern Jasper County, elected all anti-Klan candidates. ${ }^{32}$ In neighboring Barry County, the new mayor of Monett had campaigned and won with an anti-Klan stance. Likewise, residents of Anderson, in McDonald County, elected an anti-Klan mayor, city collector, and two aldermen. Even Poplar Bluff, a haven for hooded activity on the edge of Missouri's cotton belt, saw Klan-backed candidates repudiated at the polls. ${ }^{33}$ If it could be done in these small communities, it could be done in Joplin and Carthage, but it would take time.

The need for continued activism from Jasper County anti-Klan supporters in the wake of the municipal elections was not lost on Howard Gray. As president of the Carthage Anti-Klan Association, Gray had been one of the first Jasper County residents to publicly denounce the Klan. Working alongside Allen McReynolds, George Grayston, and Perl Decker, Gray served as one of the chief opponents of the Invisible Empire in

\footnotetext{
${ }^{31}$ Joplin News-Herald, 31 March 1924.

32 Jasper County Democrat, 4 April 1924.

33 Joplin Globe, 2 April 1924.
} 
Jasper County. But more than anyone else, the municipal election campaigns of JAKO and CAKA took a personal toll on Gray. During one of his public speeches, his wife received two anonymous phone calls at the family's home warning of an attack on her husband at a meeting. Frightened by the revelation, Mrs. Gray headed to the meeting location with a few family members where they found Howard Gray unharmed and unaware of the threats. Upon leaving the venue, Gray received a police escort back to his residence. The ordeal sent Mrs. Gray into a state of shock, and she spent several days recovering. ${ }^{34}$ Nevertheless, Jasper County's anti-Klan supporters continued on despite the threats. Only days after the municipal elections, George Grayston announced that:

The leaders of the anti-klan [sic] movement were not discouraged over the showing made by the new organization, which accomplished a great deal in its brief two weeks preceding the primary and election. It is the intention to perfect and enlarge our organization...we will carry on the battle for free government in city, state and nation as provided for in the constitution of the United States. ${ }^{35}$

As news of the Klan's victory in Joplin and Carthage reached St. Joseph, the city was preparing for its own municipal election. Similar to what had happened in Jasper County, and points throughout Missouri, the St. Joseph municipal election was an intense fight between Klan and anti-Klan factions. However, compared to Jasper County, Buchanan County lacked a unified anti-Klan organization. The city did have a chapter of the American Unity League, but following a wave of activity around the time of its founding in 1922, the local AUL had grown relatively benign in its targeting of the Klan.

\footnotetext{
${ }^{34}$ Joplin Globe, 1 April 1924; Joplin News-Herald, 1 April 1924.

${ }^{35}$ Jasper County Democrat, 4 April 1924.
} 
Though lacking a unified front, St. Joseph's anti-Klan supporters prepared to use their votes in the municipal election to cast a major blow to the Invisible Empire.

In the weeks leading up to the election, early indications suggested that St. Joseph Klan No. 4 favored the local Republican Party. ${ }^{36}$ In the three-way mayoral race between Republican Alva F. Lindsey, Democrat Henry Grosser, and Independent George Birt, Klan officials made it known that they wanted Lindsey. Beyond the coveted mayor's seat, the Klan held a slight preference for Republicans at Auditor and on the School Board, but the order split the remaining positions of Treasurer, Police Judge, and City Council between both parties. ${ }^{37}$ Noting the non-partisan position of the local Klan, the Missouri Valley Independent informed its readers that the Klan was a "movement" and did not back any singular political party. ${ }^{38}$ However, the local Klan held tightly to its support of Alva Lindsey, with Exalted Cyclops William Campbell going so far as to order Klansmen to either back Klan supported candidates like Lindsey or leave the hooded order. ${ }^{39}$

To the casual observer, it would seem that the Klan's backing of Alva Lindsey in the mayoral race set the basis for a classic Klan versus anti-Klan fight in St. Joseph. In fact, both the St. Joseph Gazette and St. Joseph News-Press tried to pitch the election as a Republican-Klan/Democrat-anti-Klan battle royal. But the spring campaigns were far less cut and dry. For starters, Alva Lindsey was not completely sure he wanted the

\footnotetext{
${ }^{36}$ St. Joseph Gazette, 24 March 1924.

${ }^{37}$ St. Joseph Gazette, 1 April 1924; St. Joseph News-Press, 1 April 1924, 2 April 1924.

${ }^{38}$ Missouri Valley Independent, 27 March 1924.

${ }^{39}$ St. Joseph News-Press, 8 April 1924
} 
Klan's support. At a Republican political rally, Lindsey concluded his speech by informing the audience that he had not solicited the Klan's endorsement, nor was he a member of the Invisible Empire. Instead, Lindsey advised potential voters, Klansmen or other, to review his platform before casting a vote. ${ }^{40}$ Lindsey's decision to take the middle road on the Klan situation left his Democratic challenger, Henry Grosser, with an opening to denounce the Invisible Empire and firmly attach Lindsey to the endorsement. Grosser took neither path. Instead, Grosser told the audience at a Democratic rally that the Klan had not endorsed him, but he would accept the vote of anyone who felt that he was a better candidate than Lindsey, including Klansmen. ${ }^{41}$

With both candidates seemingly appealing to potential Klan voters, St. Joseph's African American leaders soon came together to discuss the hooded specter surrounding the mayoral campaign. In a three hour meeting at the courthouse, a crowd of roughly one hundred hotly debated the merits of Alva Lindsey and Henry Grosser. Taking up the cause of Lindsey was W.A. Hill, editor of St. Joseph's African American newspaper The National Protest. Hill, though concerned about the Klan's endorsement of Lindsey, called on those assembled to back the entire Republican ticket, with the exception of school board candidate A.J. Clark, who Hill thought was a Klansman. Hill's support for Lindsey found a fierce detraction from Rev. N.T. Walker. Over objections from Hill that Lindsey never requested the Klan's endorsement, Walker reminded the crowd that "there is precious little difference between a man indorsed by the klan [sic] and a klansman [sic]... and I refuse to vote for a candidate who seems to be in league with that society."

\footnotetext{
${ }^{40}$ St. Joseph Gazette, 1 April 1924; St. Joseph News-Press, 1 April 1924.

${ }^{41}$ St. Joseph News-Press, 2 April 1924.
} 
Though attendees leaned towards issuing a resolution supporting Lindsey and the Republicans, especially after W.A. Hill suggested that Grosser would not denounce a Klan endorsement if it were extended to him, the tumultuous meeting adjourned with little action or plan for unity. ${ }^{42}$

While voters discussed if they would vote along Klan/anti-Klan lines or keep their political party allegiance, the local Klan used the pages of the Missouri Valley Independent to make a case for its preferred candidates. When it came time to champion Alva Lindsey, the newspaper laid out his solid record as the City Counsellor where he aided in the negotiations of several community improvement projects and rarely lost a case. ${ }^{43}$ His record of efficiency indicated to the Independent that it was "no time for change." Turning its attention to Henry Grosser, the newspaper continually brought up that he had few accomplishments as a public servant, including his time on the city council. Instead, the Independent felt that Grosser would staff city hall with a long list of his "good friends" with questionable backgrounds. ${ }^{44}$

Henry Grosser may have felt the bite of the Missouri Valley Independent, but its accusations directed at him were relatively minor compared to the comments leveled at William T. Gray. A Republican incumbent running to retain his position as a Police Judge, Gray was one of the prime targets of the local Klan because, as the Independent claimed, he preferred to "serve the interests of the underworld." Considering his neglect for the "spirit and letter of the law," the newspaper called on Gray to retire rather than

\footnotetext{
${ }^{42}$ St. Joseph Gazette, 1 April 1924; St. Joseph News-Press, 1 April 1924.

${ }^{43}$ Missouri Valley Independent, 27 March 1924, 3 April 1924.

${ }^{44}$ Missouri Valley Independent, 27 March 1924, 3 April 1924.
} 
seek re-election. The Independent also circulated allegations that Otto Theisen had been selected to run for Police Judge in the Democratic primary so that he could be a sacrificial lamb for Gray in the municipal election. When Klan-backed W.E. Reese won election as the Democratic challenger to Gray, the Independent felt confident that the incumbent's remaining time in office would be short. ${ }^{45}$

In addition to waging war against unfavorable candidates, the local Klan also held a major rally just before Election Day. Labeled by the Missouri Valley Independent as the "greatest ceremonial which the Klan has ever had locally," the event drew thousands of Klansmen and -women from Missouri, Kansas, Nebraska, and Iowa. ${ }^{46}$ While the Klan's auditorium filled with anxious members concerned about the possible outcomes of the upcoming election, the majority of those in attendance were there to see the Imperial Kloncilium. Headed by Hiram Evans, the Imperial Kloncilium was the sixteen member national governing body of the Invisible Empire. Evans, and other members of the Kloncilium, told the crowd of the hooded order's progress around the country. ${ }^{47}$ Exalted Cyclops William Campbell used his time on stage to discuss the "great influence for good that the local organization is exercising in every branch of civic affairs." ${ }^{48}$ When the rally ended, the Independent expressed confidence that all in attendance went home

\footnotetext{
${ }^{45}$ Missouri Valley Independent, 3 April 1924.

${ }^{46}$ Missouri Valley Independent, 3 April 1924.

${ }^{47}$ Missouri Valley Independent, 3 April 1924; St. Joseph Gazette, 30 March 1924.

${ }^{48}$ Missouri Valley Independent, 3 April 1924.
} 
"satisfied in the realization that the force of the Klan, along with its good influence in the country, is constantly growing." ${ }^{49}$

The Independent may have felt confident in the "good influence" of the Klan, but St. Joseph voters had a different opinion. When the dust settled on Election Day, St. Joseph Klan No. 4 was in shock. The constant drum beat of Alva Lindsey's predictable landslide victory was silenced when Henry Grosser won by 109 votes. Even a late evening voter surge from Lindsey supporters could not topple Grosser. The day was not a complete loss for the Klan as all of the remaining candidates on the preferred ticket were victorious, including W.E. Reese's defeat of William Gray, but the Missouri Valley Independent did not note an "election triumph" for the Klan in St. Joseph as it did in its coverage of other communities because of Alva Lindsey's loss. ${ }^{50}$ To brighten the spirits of the community following the intense election, and to revel in its victory, the local Democratic Party hired a band to march around St. Joseph playing lively tunes. On its way to a victory party for Grosser at the St. Francis Hotel, the band made sure to stop by the offices of local Klansmen to play dirges. ${ }^{51}$

While Henry Grosser's election as St. Joseph's mayor certainly stung the local Klan, not all was lost in Lindsey's defeat. The Invisible Empire, by way of the sympathetic Missouri Valley Independent, could still claim strong membership numbers in several communities throughout northwestern Missouri thanks to the recruiting efforts of St. Joseph Klan No. 4. Under the tutelage of Exalted Cyclops William Campbell, St.

\footnotetext{
${ }^{49}$ Missouri Valley Independent, 3 April 1924.

50 St. Joseph News-Press, 9 April 1924; Missouri Valley Independent, 10 April 1924.

${ }^{51}$ St. Joseph News-Press, 9 April 1924.
} 
Joseph Klan No. 4 became one of the strongest Klan chapters in the state. Campbell, himself, served as the de facto leader of the Missouri Klan, answering only to Imperial Klan Representative George McCarron and senior Klan officials in Atlanta. Yet, Missouri's Grand Dragon had much bigger plans than just political success at the municipal and county level. In what would become a common theme for Klan officials throughout the United States, Missouri's hooded order attempted to mobilize as a political organization with power throughout the entire state. However, the state Klan was never able to wield considerable influence within either political party outside of the county-level. As such, the organization failed to unite with one party over the other in major campaigns. Instead, the preference of leaders like William Campbell to back Republicans such as Calvin Coolidge for national office while favoring Democrats like A.W. Nelson for governor divided rather than united the state's hooded members because they felt a loss of autonomy when advised on how to vote. For many, it seemed that the Klan had abandoned its non-partisan stance in favor of currying favor with whichever political party held strength in a particular locality.

The municipal elections in Joplin, Carthage, St. Joseph, and points throughout Missouri indicated the ebb and flow of the Invisible Empire's political strength at the local level, but the state conventions turned April into an intense month for both Republicans and Democrats as divisive battles for control between Klan and anti-Klan factions threatened to tear the respective parties apart. The Democrats met first in Springfield and their convention quickly devolved into rural versus urban factions. Even before the convention, rural delegates made it clear that they had no intention of approving an anti-Klan plank because they feared that any action taken against the Klan 
would be "political suicide." They also worried that such an action would lead to Klansmen actively using their influence in the state to defeat Democratic candidates. ${ }^{52}$

Despite rural pushback against an anti-Klan plank, urban delegates felt confident that a vote on such a measure would eventually reach the convention floor. To assuage both sides, the writers of the possible anti-Klan plank used vague language advocating for religious liberty and strict enforcement of the law through legal means. The document still emphasized anti-Klan sentiments, but it was crafted with the hope of not alienating possible Klan-leaning delegates. In addition to addressing an anti-Klan plank, state Democrats arrived at the convention with the intention of attacking Republicans on the trade and tax policies of the Hyde administration which were seen as detrimental to Missouri's agricultural interests. ${ }^{53}$ The Democrats also planned to hit Republicans on the scandals surrounding state officials, including State Pure Food and Drug Commissioner Charles Prather and State Labor Commissioner Heber Nations (see Chapter 6). ${ }^{54}$ Finally, the convention paid homage to Woodrow Wilson who passed away in February. ${ }^{55}$

Foreseeing that the Democrats were trying to avoid the Klan issue with an innocuous plank on intolerance, the St. Louis Post-Dispatch alleged that Democrats were "expected to yield to the persuasion that it is better to be successful than to be right." 56 After all, the Post-Dispatch claimed, wouldn't the Democrats be in a stronger position on

\footnotetext{
52 St. Louis Post-Dispatch, 14 April 1924; Kansas City Star, 15 April 1924, 16 April 1924.

${ }^{53}$ St. Louis Post-Dispatch, 14 April 1924; Kansas City Star, 15 April 1924, 16 April 1924.

${ }^{54}$ St. Louis Post-Dispatch, 14 April 1924; Kansas City Star, 15 April 1924, 16 April 1924.

${ }^{55}$ St. Louis Post-Dispatch, 14 April 1924; Kansas City Star, 15 April 1924, 16 April 1924.

${ }^{56}$ St. Louis Post-Dispatch, 15 April 1924.
} 
the Klan issue if they denounced the Invisible Empire and the Republicans did not? Likewise, the newspaper posited that if both parties denounced the Klan, and actively fought against its influence, there would be no need to worry about any repercussions from promoting an anti-Klan plank. By pushing such an "innocuous platform," the PostDispatch condemned state Democrats for the "offering of pacifiers to offend nobody."

Though the Klan issue was the elephant, or rather donkey, in the room at the opening of the convention, state Democrats tried to stave off internal dissension by avoiding an open discussion of the possible anti-Klan plank. By the middle of the relatively harmonious convention, however, urban delegates had had enough. They wanted the anti-Klan plank brought to the floor of the convention for a vote. Such a move by the urbanites grew out of the anger over the decision of the Resolutions Committee to bypass the Klan issue. It was in that committee meeting that an anti-Klan plank proclaiming that "we denounce any organization whose purposes, whatever they may be, are based upon race hatreds or religious prejudices..." was voted down by a 2-to1 margin. Committee members, including some that admitted to holding personal opposition to the Klan, then issued a consensus opinion that the Democrats should not pick a fight with the Invisible Empire. ${ }^{58}$

As the announcement of the Resolutions Committee's decision circulated through the convention floor, urban Democrats pushed for a roll call on their anti-Klan resolution. Pandemonium ensued. The aisles of the convention hall filled with Klan and anti-Klan supporters who pushed their way to the front podium to plead their respective cases. The

\footnotetext{
57 St. Louis Post-Dispatch, 15 April 1924.

${ }^{58}$ St. Louis Post-Dispatch, 16 April 1924; Kansas City Star, 16 April 1924.
} 
repeated demands for a roll call on the anti-Klan resolution were met with a swift rebuke from the chairman's platform. Given a chance to speak, anti-Klan delegates asked their fellow convention attendees if they were going to allow the party to evade the issue. John Taylor of Keytesville wondered aloud if the United States Capitol would remain in Washington D.C. or move to the Klan's headquarters in Atlanta. As the convention teetered on all-out war, David A. Ball, a once "powerful leader in the party" from the northeastern Missouri town of Louisiana, rose to speak. "You are trying to lug in here things that don't belong here," he told anti-Klan delegates. Turning to the entire convention crowd, Ball offered a strong defense of the Invisible Empire. "They are good sincere citizens," he advised the crowd, "They believe in civil and religious liberty." As a round of hisses sounded from portions of the convention floor, Ball argued that "if you had continued Ku Klux Klans [sic] in St. Louis with masks on you'd have fewer bootleggers than you've got...[t]he best men in Missouri advocate what I'm talking about here." $" 60$

To counter Ball's claims, George M. Coombs Jr., Assistant Prosecuting Attorney of Jackson County, took to the podium to give the anti-Klan response. Outraged over Ball's comments, Coombs directed his words at the Klan sympathizers in the crowd. "Two years ago the Democratic Party declared against the Klan," he reminded the crowd, "[b]ut now out of the mists of yesterday rides a white and ghastly specter. Faster and faster thud the hoofbeats of horses that you ride in the dary [sic] system of hatred. Before

\footnotetext{
${ }^{59}$ St. Louis Post-Dispatch, 16 April 1924; Kansas City Star, 16 April 1924; Joplin Globe, 17 April 1924.

${ }^{60}$ St. Louis Post-Dispatch, 16 April 1924; Kansas City Star, 16 April 1924; Joplin Globe, 17 April 1924.
} 
you lie the bodies of persons unborn into which crash the hoofs of your narrow fanaticism. You are robed in cowardice and you bear upon your breasts fiery crosses symbolical of brutality, intolerance and cruelty." ${ }^{\prime 1}$ At the end of Coombs' attack, and as the grumbling of opposition reverberated in the hall, delegates from Kansas City, including members of Joe Shannon and Tom Pendergast's "rabbit" and "goat" factions, descended upon the chairman's table. After several heated discussions, the group of delegates agreed upon a plank promoting civil and religious liberty and freedom of the press against "assaults from any source." The state Democrats finally passed an antiKlan plank, but it was extremely vague and weak. ${ }^{62}$

With Springfield still simmering from the Klan/anti-Klan fight that enveloped the Democratic convention, the state Republicans met in the same town a few weeks later to hash out a number of electoral issues - including the Invisible Empire. However, since the Democrats refused to give an overall denouncement of the Klan, indications pointed to Republicans reaching a similar decision. This point was not lost on the St. Louis PostDispatch which argued that if the Catholic-backed Democrats could avoid the Klan issue without major voter abandonment, then the African American-backed Republicans could likely do the same. At least one unnamed delegate who assured his fellow Republicans that Missouri Klansmen would overwhelmingly favor the party because of the Catholic ties of the Democrat-Pendergast Machine shared this sentiment in the press. There was also a feeling that urban Republicans would not be as strongly anti-Klan as their Democratic counterparts, particularly since the Klan had allegedly aided the Republican

\footnotetext{
${ }^{61}$ St. Louis Post-Dispatch, 16 April 1924.

62 St. Louis Post-Dispatch, 16 April 1924; Kansas City Star, 16 April 1924.
} 
Party in Kansas City ${ }^{63}$ All the convention delegates had to do was pass a "religious liberty" plank similar to the Democrats, and ensure that the Klan issue did not engulf the convention in controversy. Yet, as delegates arrived, many wondered if the St. Louis contingent would wage a solo war against the Invisible Empire.

If Republicans assumed that they could avoid the Klan issue and still retain a high level of voter support from African Americans, they were mistaken. Already uneasy over the party's lack of motivation to denounce the Klan, black Republicans also worried that party officials were not keeping their promises on issues like civil rights and patronage, particularly delegate appointment. Many hoped that Walthall Moore, the first African American member of the state legislature, would be a serious contender for a delegate spot at the national party convention. When Moore was stricken from consideration by backers of Governor Hyde, resentment bellowed from the African American press. This objection was somewhat tempered when Moore and W.L. McKee of Poplar Bluff were eventually made alternate delegates, but concerns continued to bubble under the surface. ${ }^{64}$ For 1924, at least, Republicans put the issue of African American support to rest by strengthening the bite of the proposed anti-Klan plank. Adopted over few objections, as much of the rest of the planks of the Hyde-dominated convention were as well, the anti-Klan resolution stated that the Republican Party had "no sympathy with any movement that fosters religious or racial hatreds" and "we...express our unalterable

\footnotetext{
${ }^{63}$ St. Louis Post-Dispatch, 18 April 1924, 27 April 1924; Kansas City Star, 28 April 1924, 29 April 1924.

${ }^{64}$ St. Louis Argus, 16 May 1924; St. Louis Post-Dispatch, 29 April 1924, 11 May 1924.
} 
opposition to any organization or movement which proscribes any class of citizen because of birth, religion, race or color." ${ }^{, 65}$

The Republicans' anti-Klan resolution, as the Democrats before them, made no specific reference to the Klan, nor mentioned the name of the organization. While Republicans felt comfortable with the relative safety of their "stronger," but still vague, plank, the Ku Klux Klan overwhelmingly supported it. In a statement issued by Imperial Representative George C. McCarron, and sent from the hotel room of Jefferson City Exalted Cyclops Heber Nations, the Klan stated its agreement with the resolution because it was "in harmony with all of the fundamental principles of the Ku Klux Klan."66 Despite the sudden hooded approval of an alleged anti-Klan plank, delegates did not feel that it was necessary to amend the wording. This did not sit well with the editors of the St. Louis Post-Dispatch who, despite agreeing that the Republicans' plan was stronger than the Democrats, criticized the party for not mentioning the Klan by name. Since both parties had exhibited cowardice and avoided the issue, the Post-Dispatch notified voters that it was their responsibility to "take the matter in hand and reject the candidates of any party who do not clearly and specifically condemn and repudiate the klan [sic] organization." $" 67$

While it faced criticism in the press, Louis Aloe, a Jewish businessman from St. Louis, supported the Republican's anti-Klan plank. Aloe, who had dealt with antiSemitism and the Klan as a member of the city's Board of Aldermen, felt it necessary to

${ }^{65}$ St. Louis Post-Dispatch, 29 April 1924, 30 April 1924; Kansas City Star, 29 April 1924, 30 April 1924.

${ }^{66}$ St. Louis Post-Dispatch, 30 April 1924; Joplin Globe, 30 April 1924.

${ }^{67}$ St. Louis Post-Dispatch, 30 April 1924. 
speak out on the Invisible Empire and called out those who were not making a "real man's fight" against the Klan, particularly Louis Marshall of the American Jewish Committee. Marshall, one of the most prominent Jews in the United States, publicly denounced attempts by various state conventions to adopt anti-Klan planks because "if left alone, the Klan will die a natural death." In response, Aloe expressed concerns that Marshall was "not familiar with the situation of the Klan in the Middle West, in the South, or in the Southwest." ${ }^{98}$ In a letter to J.A. Harzfield of Kansas City, reprinted in The Modern View, Aloe made it clear that he was not "lacking in backbone, courage, and real manhood." "Decent men hate a coward, and I shall raise my voice in "political denunciation' of the Klan whenever the occasion is appropriate," he told Harzfield, because "the quickest way to destroy the Klan is to demonstrate to the Klan merchant and Klan politician that the anti-Klan is stronger than the Klan." ${ }^{, 69}$

Louis Aloe's fiery rhetoric may not have been shared by all anti-Klan politicians in Missouri, but many hoped that delegates to the national party conventions would adopted the tactics of some at the state level and attach resolutions denouncing the Invisible Empire to the party platforms. When the respective conventions concluded, however, anti-Klan activists left for their homes states disappointed. Though prominent party leaders, including Senator James A. Reed, former Missouri governor Herbert Hadley, and current governor Arthur Hyde, expressed support for an anti-Klan plank if it were presented, the Democrats and Republicans decided to offer only vague rebukes of

\footnotetext{
68 The Modern View, 30 May 1924, 20 March 1925.

69 The Modern View, 30 May 1924. For Louis Marshall's views on the Ku Klux Klan see M.M. Silver, Louis Marshall and the Rise of Jewish Ethnicity in American: A Biography (Syracuse: Syracuse
} University Press, 2013), 462-466. 
the Invisible Empire. As the state conventions had done before them, both parties decided to denounce attacks on civil and religious liberty, but they refused to denounce the Klan by name. ${ }^{70}$ After trumpeting the need of the Democratic delegates to denounce the Klan by name throughout the convention, the St. Louis Post-Dispatch felt that the party had given in to "cowardice." "With the two major parties afraid to point a finger at the klan [sic], why should not brighter dreams enthrall Emperors and Dragons and Kleagles and inspire them to new aggressions and larger conquests..." the newspaper lamented. ${ }^{71}$

The label of "cowardice" in regards to the Klan issue stung many Missouri politicians. While some were relieved that the so called anti-Klan planks of the state and national parties had been vague enough to placate both Klan and anti-Klan supporters, others realized that the summer before the August primary was going to be another bloody battleground for both parties with the hooded order at its center. With the Klan undertaking a recruiting campaign aimed at increasing membership and electing sympathetic candidates for public office, anti-Klan activists understood that weakness against white robed forces showed complacency, or worse, quasi-support. Emboldened by the mixed success in municipal elections around the state, Klan officials hoped that

\footnotetext{
${ }^{70}$ For information on the national party conventions see Chalmers, Hooded Americanism, 202212; McVeigh, The Rise of the Ku Klux Klan, 27-28, 184-187; Pegram, One Hundred Percent American, 212216. At one point during the Democratic National Convention, John Keegan, a delegate from St. Louis, grabbed the Missouri placard pole with the intention of marching with it in an anti-Klan demonstration parade on the convention floor. Frank $\mathrm{H}$. Farris, a delegate from Rolla, along with some fellow delegates wrestled the placard away from Keegan. After police officers arrived on the scene, a truce prevented further fighting. Farris, a supporter of William McAdoo, later claimed that he was not opposed to antiKlan sentiments, but he felt that it was not the right time for the placard to be included in the parade. St. Louis Post-Dispatch, 26 June 1924.

${ }^{71}$ St. Louis Post-Dispatch, 30 June 1924.
} 
reaching out to potential voters throughout the summer and fall would lead to a triumph at the polls in November. Seeking to unify Missouri Klansmen behind a select group of candidates, the organization held a Klonvokation in the House of Representatives chamber of the state capitol building in Jefferson City in mid-July. Using the Klan's Klonvokation as the center of its attack, the state's anti-Klan forces mounted a public pressure counter-strike in an attempt to thwart the gains made by the Klan through its political activism.

The Klan's July Klonvokation was not the first time the hooded order had used the House chamber for a meeting. In February 1924, Reverend Z.A. Harris of Oklahoma gave a speech on One Hundred Percent Americanism and the Ku Klux Klan before a large audience. Harris' "evangelical meeting," along with the Jefferson City Klan's decision to post fliers for the event throughout the community, including on the front door of the nearby St. Peter's Catholic Church, drew state-wide outrage from anti-Klan supporters. Those attacking the Klan's use of the capitol grilled Governor Hyde over why he allowed an intolerant organization such as the Klan to have access to the legislative chambers. ${ }^{72}$ In response to the criticism, Hyde reiterated his stance of opposition to the Klan while claiming to be unaware of Harris' speech until the press published the story. The blame was ultimately passed between Harry Woodruff (the superintendent of the Permanent Seat of Government, which controlled use of the Capitol

\footnotetext{
72 W.S. O'Brien to Arthur Hyde, 15 February 1924, Folder 368, Collection 7, AMH, SHS-MO; Vincent M. Carroll to Arthur Hyde, Western Union Telegram, 14 February 1924, Folder 368, Collection 7, AMH, SHS-MO; Fred E. Kies to Hiram Lloyd, Western Union Telegram, 16 February 1924, Folder 368, Collection 7, AMH, SHS-MO; St. Louis Post-Dispatch, 14 February 1924, 15 February 1924, 16 February 1924, 22 February 1924. For letters supporting the Klan's use of the capitol see Sam J. Corbett to Arthur Hyde, 23 February 1924, Folder 368, Collection 7, AMH, SHS-MO; Harry Houck to Arthur Hyde, 25 February 1924, Folder 368, Collection 7, AMH, SHS-MO; Guy Davis to Arthur Hyde, 26 February 1924, Folder 368, Collection 7, AMH, SHS-MO.
} 
building); Heber Nations (State Labor Commissioner and Exalted Cyclops of the Jefferson City Klan chapter); and Fred Hueller (a watchman for the Permanent Seat of Government who allegedly first asked for use of the legislative hall). ${ }^{73}$

Still reeling from the significant criticism he received from both Klan and antiKlan supporters regarding his stance on the Invisible Empire after Z.A. Harris' lecture as well as the fight in the state and national Republican conventions over the anti-Klan plank, Governor Hyde took a much more heavy handed approach to the Klan's Klonvokation in July. ${ }^{74}$ Upon learning that the Klan was not only meeting in the legislative chambers for the Klonvokation, but that its officials had locked the doors to prevent unwanted visitors, Hyde ordered the Klan to either open the chamber doors to curious citizens or leave the capitol building. The Klan complied with Hyde's request, but before reporters could properly situate themselves in the upper gallery to observe the festivities, Klan officials decided to move the Klonvokation to the nearby headquarters of the Jefferson City Klan at the Merchants Bank Building. While hooded officials told the press that the Klonvokation was arranged so that the order could discuss how best to aid law enforcement in the future, it information circulated that portions of the meeting were

\footnotetext{
73 Jefferson City Democrat-Tribune, 14 February 1924, 15 February 1924, 16 February 1924; Cole County Weekly Rustler, 27 November 1925; St. Louis Post-Dispatch, 14 February 1924, 15 February 1924, 16 February 1924.

${ }^{74}$ For letters criticizing the Republicans' anti-Klan plank see C.P. Covington to Arthur Hyde, 28 April 1924, Western Union Telegram, Folder 368, AMH, SHS-MO; E. Martindale to Arthur Hyde, 30 April 1924, Folder 368, AMH, SHS-MO; Yates Fishback to Arthur Hyde, 1 May 1924, Folder 368, AMH, SHS-MO; J.H. Jewett to Arthur Hyde, June 1924, Folder 368, AMH, SHS-MO; Paston Ginsey to Arthur Hyde, 27 June 1924, Folder 368, AMH, SHS-MO.
} 
dedicated to notifying Klansmen of the organization's preferred candidates for the August primary. ${ }^{75}$

Compared to the reaction after Z.A. Harris’ February Klan speech, Hyde's decision to force the Klan out of the Capitol elicited much more positive feedback. The St. Louis Post-Dispatch felt that Hyde was "right" in denying the Klan closed door use of the legislative chambers. "It is free to preach its intolerant doctrines whenever it pleases," the newspaper told its readers, "[but] its teachings are abhorrent to the principles upon which American government is founded and there might be solid ground for the objection to the use of the Capitol building." 76 Some Missourians wrote to Hyde and expressed the sentiment that "it is high time for all good american [sic] people to place their stamp of disaproval [sic] on all such un-american organizations."77 Yet, others explained their disappointment at the governor's decision: “[y]ou may yet reach the place where you will be proud of the Klan in Missouri."78

In response to the increase in Klan activity, particularly the move towards more overt political activism through the Klonvokation, the anti-Klan press critiqued attempts by the hooded order to sway voters in the upcoming election. Noting the Klan's political

75 Jefferson City Democrat-Tribune, 12 July 1924, 14 July 1924, 15 July 1924; Jefferson City Daily Capital News, 13 July 1924, 15 July 1924; Jerry Butcher, Ku Klux Klan: The "Invisible Empire" in the Missouri Capital, Governor Arthur M. Hyde Versus the Ku Klux Klan (1966).

${ }^{76}$ St. Louis Post-Dispatch, 14 July 1924.

77 Robert McCoy to Arthur Hyde, 14 July 1924, Folder 368, Collection 7, AMH, SHS-MO. For other letters regarding Hyde's stance on the Klan Klonvokation see Joseph H. Dusenberry to Arthur Hyde, 14 July 1924, AMH, SHS-MO; Hugh W. Maxey to Arthur Hyde, 14 July 1924, AMH, SHS-MO; T.C. Owen to Arthur Hyde, 14 July 1924, AMH, SHS-MO; Jas. Lieber to Arthur Hyde, 15 July 1924, AMH, SHS-MO; E.A. Favier to Arthur Hyde, 15 July 1924, AMH, SHS-MO; J.W. Vincent to Arthur Hyde, 16 July 1924, AMH, SHSMO; J.D. Whitman to Arthur Hyde, 16 July 1924, AMH, SHS-MO; Al Covin to Arthur Hyde, 28 July 1924, AMH, SHS-MO.

${ }^{78}$ Hugh Q. Miller to Arthur Hyde, 13 July 1924, Folder 368, Collection 7, AMH, SHS-MO. 
influence in the states of Indiana, Georgia, and Texas, the St. Louis Post-Dispatch advised its readers that "the only safety for the opponents of secret invisible government through a masked organization is to make the issue open to defeat the klan's [sic] plans to control nominations and to condemn the organization unequivocally by name." ${ }^{, 79}$ Also casting a careful eye upon elections involving the Klan out of state, the Kansas City Jewish Chronicle warned that Indiana's governor's race would "prove a barometer of the strength that can be mustered in a typically American community of average intelligence by the forces of darkness, malevolence, and class hatred." 80

One prime example of the anti-Klan critique of the hooded order's courting of voters centered on four controversial donations the Klan made in Jefferson City. While the main news coming out of Jefferson City that summer focused on Governor Hyde expulsion of the Klan from the capitol building, the organization sought to improve its image by rallying support through local donations. In doing so, though, it added fuel to the fire of growing opposition. The controversy started when the Jefferson City Klan decided to donate twenty-five dollars to four local Protestant churches. ${ }^{81}$ This was not unusual for the Klan in Missouri or even nationwide. In seeking to tie in the group's Protestantism as well as its role in local philanthropy, Klan chapters throughout the state often donated large sums of money to churches and local causes. ${ }^{82}$ In Jefferson City, the

\footnotetext{
${ }^{79}$ St. Louis Post-Dispatch, 8 May 1924.

${ }^{80}$ Kansas City Jewish Chronicle, 30 May 1924.

81 Jefferson City Democrat-Tribune, 21 July 1924.

82 Pegram, One Hundred Percent American, 38-39
} 
Klan donated over $\$ 1000$ each to the Boy Scouts and the Salvation Army. ${ }^{83}$ It also donated money to several churches in rural Cole County and to Reverend W. Hooper Adams upon his retirement from the First Presbyterian Church. In most instances, the Klan handed out the donations in full regalia. ${ }^{84}$ These new donations, however, were quite different.

As the spiritual voices of Jefferson City's Sunday church services filled the hot, July air with hymns of praise, an African American messenger quietly stepped through the doors of the city's four black congregations. ${ }^{85}$ If not for the letters being carried, the messenger might have seemed like a traditional Sunday worshipper. Upon opening each letter, the congregants read that "all good Negroes are 100 per cent American.” Signed by the local chapter of the Ku Klux Klan, each letter praised African Americans for their patriotism and Protestantism. "Members of the Klan are glad to make public acknowledgment of the patriotism of thousands of Negroes whose blood stains our national fields of honor along with that of our gallant white soldiers," the letter read, "[i]t is our prayer that all Christian Protestants may stand four square for law enforcement,

${ }^{83}$ Pegram, One Hundred Percent American, 39; Cole County Weekly Rustler, 15 February 1924; Gary R. Kremer, Heartland History: Volume Three (Jefferson City: City of Jefferson, 2004), 33.

84 Jefferson City Democrat-Tribune, 10 May 1924, 15 December 1924; Jefferson City Daily Capital News, 16 November 1924; Cole County Weekly Rustler, 21 November 1924, 28 November 1924; Jefferson City Daily Post, 15 December 1924.

85 The four African American congregations in Jefferson City were Second Baptist Church, Second Christian Church, African Methodist Episcopal Church, and African Methodist Episcopal Zion Church. Polk's Jefferson City Directory, 1925 (Chicago: R.L. Polk \& Co., 1925), 10-11. 
loyal Americanism and unfettered Christianity." ${ }^{\$ 66}$ Accompanying each letter was a monetary donation totaling twenty-five dollars. ${ }^{87}$

The letters did not advocate equality, nor did they extend an offer of membership in the Invisible Empire. Instead, the letters informed the city's African Americans that they had nothing to fear from the Ku Klux Klan, as long as they were "good Negroes." $" 88$ But compared to other cases of philanthropy made by the Jefferson City Klan and other hooded chapters around the state, these four donations were dramatically different. In this case, Klansmen did not publicly deliver the letter and monetary donation to any of the churches. Instead, the Klan allegedly paid a local African American man to serve as the principal messenger. While it was not customary for Klansmen to personally deliver all donations, the decision to be invisible in a donation as large as this ( $\$ 100$ distributed between four churches) was unusual.

If the Klan intended to earn some positive coverage with the church donations, the press did not perceive it that way, nor published it in that manner. Instead, since the donations appeared on July $20^{\text {th }}$, news of the Klan's philanthropy circulated throughout the state just as many political candidates were beginning to wrap up their campaigns for the August primary. Though it held close ties with the Democratic Party in Jefferson City, the Klan also ensured that a few sympathetic candidates appeared on Cole County's Republican primary ballot. It would be a tough fight as the local Republicans tended to lean anti-Klan, but the Jefferson City Democrat-Tribune foresaw what the Klan planned

${ }^{86}$ St. Louis Argus, 25 July 1924.

87 Jefferson City Democrat-Tribune, 21 July 1924; Jefferson City Daily Capital News, 23 July 1924; St. Louis Argus, 25 July 1924.

${ }^{88}$ St. Louis Argus, 25 July 1924. 
to do with the donations so close to the primary. Taking the pulse of the situation, the anti-Klan Democrat-Tribune concluded that the Invisible Empire was trying to curry favor with the city's African American population who traditionally voted Republican. ${ }^{89}$

The Klan probably could not convince local blacks to switch parties to the local Democrats, but the hooded order might just be able to convince a few African Americans to throw their votes to some closely tied Republican candidates. Since the Klan had candidates on both parties ballot, such a move could have put more sympathetic candidates on the overall ballot for the General Election. Yet, despite the organization's philanthropic efforts, only one Klan-aligned candidate won in the Republican primary. The hooded order met a similar fate in the General Election when Cole County residents overwhelmingly rejected Klan-Democrat politicians - with the exception of Sheriff L.C. Withaup - and voted for Republican anti-Klan candidates. ${ }^{90}$

After news of the Klan's July church donations reached St. Louis, the Argus made it a front page story. "Nothing has caused a greater stir among church people than has this one act of the Klansmen," the newspaper informed its readers. "Some express fear of violence if the money is returned, while others say 'we cannot use it regardless of the cost'."91 When presented with his church's portion of the donation, one congregant publicly declared that "the negroes of the Baptist Church of Jefferson City are not for sale." 92 Though its pastor was out of town at the time of the donations, parishioners of

89 Jefferson City Democrat-Tribune, 22 July 1924.

90 Jefferson City Democrat-Tribune, 6 August 1924, 6 November 1924; Jefferson City Daily Capitol News, 6 August 1924, 6 November 1924.

${ }^{91}$ St. Louis Argus, 25 July 1924.

${ }^{92}$ Cole County Weekly Rustler, 1 August 1924. 
Jefferson City's Second Baptist Church informed the press that it planned to return the "tainted" money. If they were unable to return the money to the Klan, some residents suggested that ads denouncing the Invisible Empire be placed in local newspapers using the donations to cover the cost. ${ }^{93}$ As the churches debated what to do with the money, another major donation arrived at the home of Rev. H.P. Greenlee. This new letter, written by George Grayston of the Joplin Anti-Klan Organization, complimented Greenlee's congregation for its handling of the situation and offered $\$ 100$ for refusing the Klan's initial donation. ${ }^{94}$

With two churches still holding on to the Klan's donation, the Argus issued a stern warning about "blood money." While quick to condemn the Klan for its brazen and "unscrupulous attempt at bribery," the newspaper also advised the churches to reject the donations because acceptance was akin to showing "your approval on the acts of the Klan." Turning to the ministers of each church, the Argus warned that "if a preacher is so ungodly as to be willing to accept money from the Klan, then we appeal to the officers of the church to act and act speedily, for such a preacher may be properly called a traitor and a disgrace to the high calling of the christian [sic] ministry." If any of the ministers took a penny from the Klan, the newspaper called on the respective congregations to "rise in its righteous indignation and have a house cleaning." 95

${ }^{93}$ St. Louis Argus, 25 July 1924.

94 Jefferson City Daily Capital News, 27 July 1924; Jefferson City Democrat-Tribune, 28 July 1924; St. Louis Argus, 1 August 1924.

95 St. Louis Argus, 25 July 1924. 
When a week passed and Jefferson City's Second Christian Church still held the Klan's "blood money," the Argus decided to single out the church's pastor, J.W. Damel. ${ }^{96}$ Damel, who split his time between his pastorate and teaching courses at the nearby allblack Lincoln University, had been a major figure in Jefferson City's African American community since taking an appointment at Lincoln in $1890 .{ }^{97}$ In its attack on Damel, the Argus targeted his dual role in the community as preacher and teacher. Seeing his acceptance of the Klan's donation as a way to line his own pockets, the newspaper declared that Damel should be "unfrocked as a minister" because he was "wholly unfit for leadership". 98 If his congregation decided not to remove him, the Argus felt that the "blood of the victim of the Klan be upon their hands.",99

While it brought up Damel's acceptance of Klan money for his own church treasury, the bigger issue for the Argus was his continuation as an instructor at Lincoln University. By taking Klan money, the newspaper argued Damel had "forfeited his right as a teacher of Negro youth." "We would like to know," the Argus openly pondered, "is there a mother, father, or guardian in the State, who would willingly send his or her child to any school where he or she thought it would be compelled to sit under the influence of the Ku Klux Klan?"100 In the eyes of the Argus, the duty of the university was clear: it

${ }^{96}$ St. Louis Argus, 1 August 1924.

97 W. Sherman Savage, The History of Lincoln University (Jefferson City: The New Day Press, 1939), 276-278.

${ }^{98}$ St. Louis Argus, 1 August 1924.

${ }^{99}$ St. Louis Argus, 22 August 1924.

100 St. Louis Argus, 26 September 1924. 
needed to fire J.W. Damel. ${ }^{101}$ Though there are few records to show how Lincoln's administration and Board of Curators dealt with the fall-out over Damel, the press' eventual silence over Damel suggests that he survived the ordeal relatively unscathed. Despite having his name splashed across the editorial section of the St. Louis Argus for over two months, J.W. Damel served at Lincoln University for more than forty years and eventually had an industrial arts building, which still stands on campus, named after him. ${ }^{102}$

The reaction of anti-Klan supporters to the Klonvokation and the Jefferson City donation scandal shows that the press played a major role in shaping public opinion on the Invisible Empire. As it had done earlier in the 1920s, the press used this influence to pressure candidates into making public statements regarding their stance on the Ku Klux Klan during both the primaries and general election. Newspapers like the St. Louis Argus and Kansas City Call worked alongside the NAACP to distribute questionnaires to prospective candidates inquiring about their position on key issues important to the African American community, including the Dyer Anti-Lynching Bill, enforcement provisions within the $14^{\text {th }}$ and $15^{\text {th }}$ Amendments, residential segregation, equal educational opportunities, and the Ku Klux Klan. Not surprisingly, the Call found that several candidates were "unsatisfactory," while many more, including A.W. Nelson, failed to respond to the questionnaire. However, a few Republicans running for state

${ }^{101}$ St. Louis Argus, 22 August 1924, 12 September 1924, 26 September 1924.

${ }^{102}$ Savage, The History of Lincoln University, 276-278; Antonio F. Holland, Nathan B. Young and the Struggle over Black Higher Education (Columbia: University of Missouri Press, 2006), 152-155. According to Antonio Holland, soon after the Klan donation controversy, Damel was demoted to a faculty position at the high school affiliated with Lincoln University. As a former acting president of Lincoln University, Damel was not pleased with the demotion and lobbied for a return to the college faculty. 
office, particularly Sam A. Baker, gained a favorable "recommended" status for their answers. $^{103}$

While this direct questioning was aimed at candidates in all levels of government, the most highly publicized discussion of the Klan issue took place in the state's gubernatorial campaign. Though the list of major party candidates running for governor eventually was whittled down to two, Sam Baker and Arthur Nelson, the campaign to reach their respective party's nomination was far from easy. On the Republican side, Baker competed against Lieutenant Governor Hiram Lloyd and former St. Louis Police Commissioner Victor Miller. For the Democrats, it was a four-way race between Nelson, St. Louis lawyer George Moore, Jackson County public administrator Floyd Jacobs, and former federal judge Henry Priest. ${ }^{104}$ Though each man preferred to stick with key issues like agriculture, law enforcement, and taxation as the main talking points of the primary, the Klan issue soon took a central role. Nelson, who portrayed himself as a simple "dirt farmer" despite being one of the largest landowners in Cooper County, faced accusations from George Moore that he was secretly a member of the Klan. Nelson quickly

103 St. Louis Argus, 27 June 1924, 31 October 1924; Kansas City Call, 25 July 1924, 31 October 1924. For examples of the NAACP questionnaire and other inquiries about a candidate's stance on the Klan see NAACP Committee to Frank E. Atwood, July 1924, Folder 97, Frank Ely Atwood Papers, SHS-MO; Vincent M. Carroll to Frank E. Atwood, 22 July 1924, Western Union Telegram, Folder 101, Frank Ely Atwood Papers, SHS-MO; St. Louis Post-Dispatch to Frank Atwood, 24 July 1924, Western Union Telegram, Folder 101, Frank Ely Atwood Papers, SHS-MO; Frank Atwood to St. Louis Post-Dispatch, 24 July 1924, Western Union Telegram, Folder 101, Frank Ely Atwood Papers, SHS-MO; George Grayston to Frank Atwood, 24 May 1924, Folder 103, Frank Ely Atwood Papers, SHS-MO; A.E. Spencer to Frank Atwood, 29 July 1924, Folder 103, Frank Ely Atwood Papers, SHS-MO; Frank Atwood to A.E. Spencer, 31 July 1924, Folder 103, Frank Ely Atwood Papers, SHS-MO; Frank Atwood to George Grayston, 31 July 1924, Folder 103, Frank Ely Atwood Papers, SHS-MO; Frank Atwood to W.N. Andrews, 31 July 1924, Folder 103, Frank Ely Atwood Papers, SHS-MO; A.E. Spencer to Frank Atwood, 6 August 1924, Folder 103, Frank Ely Atwood Papers, SHS-MO; Frank Atwood to B.K. Blair, 2 September 1924, Folder 106, Frank Ely Atwood Papers, SHS-MO.

${ }^{104}$ Large, The "Invisible Empire" and Missouri Politics, 7-8. 
dismissed this claim, but his vague remarks in defense of his record left the door open for further attacks from Democrats and Republicans. ${ }^{105}$

A.W. Nelson, however, was not the only candidate mired in Klan rumors. Citing a "whispering campaign" aimed at tarnishing his own record, Victor Miller felt compelled to compose a letter to the St. Louis Post-Dispatch explaining that he had never joined the Klan. ${ }^{106}$ When rumors of his alleged Klan affiliation continued, Miller decided to include the denouncement in a few of his public addresses. ${ }^{107}$ For George Moore, there was no denying where he stood on the Klan. In fact, while leveling an attack on Floyd Jacobs for alleged Klan ties, Moore also denounced the candidacy of Henry Priest because the former judge was stealing some of his anti-Klan supporters. The PostDispatch agreed that too many anti-Klan candidates on the Democratic side would be detrimental in the primary, but it nevertheless felt that Priest had a right to campaign. ${ }^{108}$ Priest, however, had his own problems. Along with Moore, he was a regular target of the Klan press. To make matters worse, at a campaign stop in Hannibal, Klansmen infiltrated his speech and staged a mass walk out whenever he denounced the Invisible Empire. ${ }^{109}$

The two candidates who avoided most of the Klan charges were Hiram Lloyd and Sam Baker. In his work on the 1924 gubernatorial campaign, John J. Large argues that

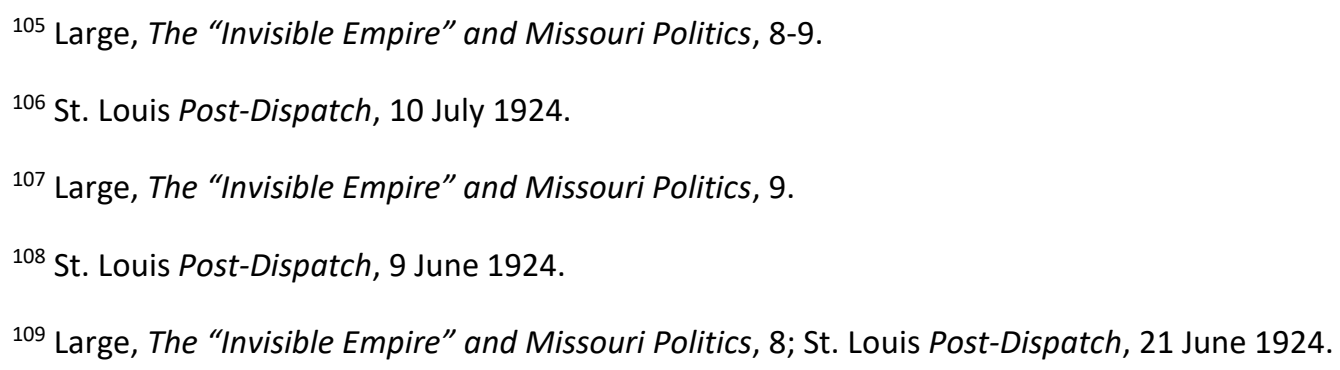


Lloyd and his supporters may have been responsible for the Klan allegations directed at Victor Miller. ${ }^{110}$ As for Baker, he brushed aside rumors that he was a member of the Jefferson City Klan by pointing out his past record on issues of intolerance while serving as the State Superintendent of Public Schools. ${ }^{111}$ However, Baker did have some questions to answer when his name appeared on the list of preferred candidates released by the Klan. Since the sample ballots listed candidates supported by the Klan for each party, Baker shared the governor's spot with Nelson. The rest of the preferred candidates for various state-level positions split between both parties. ${ }^{112}$

When the primary votes were tallied, Arthur Nelson and Sam Baker, both preferred candidates of the Klan, had won their respective party's nomination. As for other preferred candidates for state office, the Klan had some positive results as Republicans Phil A. Bennett, L.D. Thompson, Frank Atwood as well as Democrats Kate Morrow, George Middlekamp, John H. Stone, and James T. Blair were all victorious. However, William O. Stacy and Gus O. Nations were defeated. ${ }^{113}$ Nations, the brother of Klansmen Heber Nations and the son of Klan supporter and American Party presidential candidate Gilbert Nations, had the support of the Missouri Klan, but his political advertisements throughout the campaign stressed that he held no ties to the Invisible Empire. ${ }^{114}$ Surveying the carnage at the end of a bloody primary season, the Post-

\footnotetext{
${ }^{110}$ Large, The "Invisible Empire" and Missouri Politics, 9.

${ }^{111}$ Large, The "Invisible Empire" and Missouri Politics, 9.

112 Large, The "Invisible Empire" and Missouri Politics, 9-10.

${ }^{113}$ St. Louis Post-Dispatch, 5 August 1924, 6 August 1924, 7 August 1924.

${ }^{114}$ St. Louis Argus, 13 June 1924; Kansas City Call, 1 August 1924.
} 
Dispatch expressed concerns about the future. The newspaper hinted at a possible third party gubernatorial run for Henry Priest, but such a move was a folly because it would ensure Baker's victory in November. At any rate, the Post-Dispatch felt that "a liberal bolt against the domination of the Anti-Saloon League, the hooded terrorism of the Ku Klux Klan and the official lawlessness embodied in both those organizations is due in Missouri and in the nation." 115

In the brief lull between the end of the primary season and the final push towards the General Election, the Ku Klux Klan held its Second Imperial Klonvokation in Kansas City's Convention Hall. Over four days in late September, Klan officials set out "to review the Klan of yesterday, to analyze the Klan of today, to build for the Klan of tomorrow." 116 Hiram Evans, now over a year into his leadership of the Klan, also intended to use the Klonvokation to solidify the previous factionalism that emerged out of his fight with William Simmons. "The future of America, and of the white race, hangs in the balance," Evans told the assembled Klansmen, "[we] are men who see and deplore the ills of the present, and who likewise have a vision of redemption." ${ }^{117} \mathrm{He}$ did not mince words with whom or what, caused these "ills" and attempted to weaken Americanism. According to Evans, adherents to "Universalism, Sovietism [sic], Communism, Socialism, Anarchism, Judaism, and...Roman Catholicism...[are] assailing

${ }^{115}$ St. Louis Post-Dispatch, 7 August 1924.

${ }^{116}$ Knights of the Ku Klux Klan, Inc., Proceedings of the Second Imperial Klonvokation: Held in Kansas City, Missouri, Sept. 23, 24, 25 and 26, 1924 (n.p., n.d.), 54.

117 Proceedings of the Second Imperial Klonvokation, 54. 
the foundation of our civilization." "We should, we will, preserve our race purity," Evans asserted to the crowd, "we must do the work to which we are divinely called."118 In discussing its plans for the future, however, Klan officials also addressed a dark cloud on the horizon - anti-Klan activism. While singling out the "SimmonsClarke" faction by name, Evans also alluded to anti-Klan organizations and legislation, "staged" riots across the country, "vicious persecution" of Klan members, and "attempts in many States to abolish the Klan."119 Even Kansas City, the host site for the Klonvokation, had been home to similar activities. Local Klansmen explained to their hooded brethren how the city was a "hot-bed of Roman Catholicism" where anti-Klan work was "so vicious that we found it necessary to adopt measures to safeguard...the local officers here." ${ }^{120}$ Such activism had caused great unease among Klansmen while leaving "little time for the inculcation of Klan principles and the education of the millions being enrolled in our membership."121 Yet, Evans assured his followers, counteractivism, along with "the guidance of Divine Providence," allowed the Klan to continue to flourish. "We will make America a perfect nation," the Imperial Wizard told those assembled, "[thus] fulfilling the ideals of the great Statesman and Father who laid the foundation upon which to build a civilization better than the world has ever known,

118 Proceedings of the Second Imperial Klonvokation, 145-146.

${ }^{119}$ Proceedings of the Second Imperial Klonvokation, 61.

${ }^{120}$ Proceedings of the Second Imperial Klonvokation, 222.

${ }^{121}$ Proceedings of the Second Imperial Klonvokation, 63. 
wherein free men may live and rear their children in liberty, security and justice -

untainted by the blood of alien races and unhampered by mental and spiritual tyranny."122

Evans intended for such a statement to boldly inspire Klansmen who worried about the organization's long-term effectiveness, as well as serve as a trump card for those who argued that the Invisible Empire was withering under anti-Klan pressure. But even Klansmen had to admit that the empire was not as vast as Evans and others implied. The Report of the Imperial Kligrapp showed that nearly three thousand Klan chapters existed nationwide, yet these numbers were severely skewed. While over $80 \%$ of the Klan's membership lived in the Upper Midwest and the modern-day Sunbelt, less than $20 \%$ of Klansmen resided in New England, the Mid-Atlantic, and large portions of the West. ${ }^{123}$ In many ways, this uneven distribution of Klan membership would ultimately contribute to the organization's inability to mobilize as an effective player in national politics.

With the Klan issue saturating election campaigns from municipal contests to the presidential race; it is not surprising that it was the focal point of the final push towards Election Day in November. As seen earlier in this chapter, the campaign for governor was muddied during the primaries as each candidate faced accusations and rumors surrounding their possible Klan affiliation. Out of this quarrel emerged Sam Baker and

122 Proceedings of the Second Imperial Klonvokation, 79.

${ }^{123}$ Proceedings of the Second Imperial Klonvokation, 100-101. The 81.9\% of the Klan's population resided in Louisiana, Texas, New Mexico, Arizona, Arkansas, Oklahoma, Mississippi, Alabama, Georgia, Florida, South Carolina, North Carolina, Virginia, Kentucky, Tennessee, West Virginia, Illinois, Indiana, Wisconsin, Ohio, Michigan (21 states). The $18.1 \%$ of the Klan's population resided in California, Nevada, Utah, Colorado, Oregon, Washington, Idaho, Wyoming, Montana, North Dakota, South Dakota, Minnesota, lowa, Missouri, Nebraska, Kansas, Pennsylvania, Delaware, Maryland, New Jersey, New York, Connecticut, Rhode Island, Massachusetts, New Hampshire, Vermont, Maine (27 states). 
Arthur Nelson. They were bloodied by the campaign, but they soon emerged as the leaders of their respective state parties. Yet, if either man assumed that the Klan issue would go away after the primaries, they were wrong. Instead, both faced accusations of having joined Klan chapters in their home counties (Nelson in Cooper County, Baker in Cole County).

More than anything else, the Missouri governor's race felt the impact of a series of affidavits released by the state Republican Party that detailed Arthur Nelson's alleged close relationship with the Invisible Empire. "We do not believe that the people of Missouri desire their chief executive to be Janus-like," Republican State Committee Chairman William Phares told the press upon releasing the documents. ${ }^{124}$ The timing of the affidavits, combined with Phares' moral "outrage" over the allegations, was an intended guise to smear Nelson's campaign with little opportunity for an effective rebuttal before Election Day. In many ways, this tactic worked. Though rumors of Nelson's Klan affiliation had emerged during the previous summer, the new affidavits, and Nelson's admittance that he had been to at least two Klan events, cast serious doubt over the Democrat's campaign for governor. ${ }^{125}$

William Phares' decision to release affidavits attesting to A.W. Nelson's Klan status only two weeks before Election Day sent the state's Democratic Party scrambling to counter the charges. As he had done in the primaries, Nelson initially brushed the accusations aside. Soon after, Democratic State Committee Chairman Joshua Barbee

\footnotetext{
124 Jefferson City Daily Capital News, October 21, 1924.

${ }^{125}$ For a detailed overview of the 1924 gubernatorial election see John Judson Large, The "Invisible Empire" and Missouri Politics: the Influence of the Revived Ku Klux Klan in the Election Campaign of 1924 as reported in Missouri Newspapers (Master's Thesis, University of Missouri-Columbia, 1957).
} 
issued a statement denouncing Phares and the Republicans. "This is a desperate attempt of the Republicans to save what they recognize as a losing fight," Barbee told the press as he publicly questioned the validity of the claims. ${ }^{126}$ When challenged by Nelson and Barbee, William Phares defended the three men who had signed the affidavits: F.A. Collins, B.L. Morris, and C.S. Burns. Citing their membership in the Klan, Phares declared that Collins and Morris had access to the order's membership book in Tipton. Turning to Burns, Phares admitted the Morgan County resident was a former Klansman, but argued that he was a reputable farmer. Phares also claimed that a prominent Klansman told him that to gain access to the California rally, Nelson would have had to have been either a Klansman or an applicant for admission. Finally, pointing out that similar accusations made during the primary, Phares reminded voters that this was not the first time that Nelson and the Klan were linked. ${ }^{127}$

Only two days after the initial release of the affidavits, A.W. Nelson declared the Klan issue closed. His supporters and the press, however, kept the issue very much alive. Leo Felton, Dr. L.M. Gray, and Ed Patterson all signed affidavits claiming that they saw Nelson leave the grounds before a Klan initiation ceremony in California. Felton added that as a member of the Knights of Columbus he had observed many Klan gatherings around Cooper County and had never seen Nelson. Additionally, Dan Chapman, the Exalted Cyclops of the Tipton Klan, issued a statement denying that B.L. Collins and F.A. Morris were Klansmen. According to Chapman, C.S. Burns had been a member but

${ }^{126}$ St. Louis Post-Dispatch, 21 October 1924, 22 October 1924.

${ }^{127}$ St. Louis Globe Democrat, October 22, 1924; St. Louis Post-Dispatch, October 22, 1924; Jefferson City Daily Capital News, October 22, 1924. 
was dropped by the group for lack of participation. Though he claimed that Nelson was not a member of the Tipton Klan and that he had not seen him at the California rally, Chapman certainly did not help Nelson's case by implying that if Nelson had been initiated at California he would be in that chapter's membership book, not Tipton's book. $^{128}$

With affidavits and claims appearing right and left, the press and the respective political parties began to craft stories about the controversy to influence voters with only days remaining in the campaign. The Democrats portrayed the allegations against Nelson as part of a larger conspiracy. Labeled the Hyde-Phares Conspiracy in honor of Republican Governor Arthur Hyde and Republican State Committee Chairman William Phares, this alleged conspiracy was a top-down plot aimed at destroying Nelson and the Democrats on the eve of the election. To aid the "conspiracy" theory, the press quoted C.P. Anderson, a state grain inspector, who claimed that he was given paid leave by the Republican State Committee to scour Cooper County looking for people to sign affidavits against Nelson. This charge earned some merit as C.S. Burns, a lifelong Republican, signed one of the key affidavits. ${ }^{129}$ In addition to the theory of a top-down conspiracy, Democrats alleged that Joseph Thompson, Governor Hyde's personal secretary, and Sam Baker, the Republican candidate for governor, had both tried to secretly become Klansmen. ${ }^{130}$

128 Jefferson City Democrat-Tribune, October 22, 1924; Kansas City Post-Journal, October 23, 1924; St. Louis Post-Dispatch, October 22, 1924; Jefferson City Daily Capital News, October 23, 1924.

${ }^{129}$ St. Louis Post-Dispatch, October 23, 1924; Jefferson City Daily Capital News, October 26, 1924.

130 Jefferson City Daily Capital News, October 29, 1924; Jefferson City Democrat-Tribune, October 29, 1924. 
When not attacking the Republican hierarchy, Democrats reminded voters of Nelson's rural background and generous demeanor. Largely avoiding the urban areas of St. Louis and Kansas City for most of his campaign, Nelson instead devoted considerable attention to rural Missouri and played up his "dirt farmer" heritage. This agricultural appeal to rural Missourians won over many farmers who were concerned about land values, taxation, and farm relief, but it also drew the ire of Republicans who ridiculed Nelson's "common man" branding. To add to this generous, man of the people persona, a story circulated soon after the initial affidavits alleging that Nelson held no hard feelings for C.S. Burns and actually recommended that the Boonville National Bank extend Burns' mortgage as a sign of goodwill because he was in danger of foreclosure. ${ }^{131}$

To the conspiratorial allegations put forth by Democrats, the Republicans responded in full. Rumors began to spread that Nelson, in addition to seeing the Klan at the Southwest Missouri Fair, had secretly met with Imperial Wizard Hiram Evans while in Carthage. ${ }^{132}$ Another allegation stated that the headquarters of the Kansas City Klan prominently displayed a portrait of Nelson. ${ }^{133}$ Additionally, when pressed by Democrats about the secretive nature under which the original affidavits were obtained, Republicans questioned the validity of Leo Felton's affidavit by pointing out that he had not been a member of the Knights of Columbus since 1913. ${ }^{134}$ They also assured voters that numerous residents of Cooper County stood at the ready to attest to Nelson's Klan

\footnotetext{
131 St. Louis Post-Dispatch, October 24, 1924; Jefferson City Democrat-Tribune, October 24, 1924; Jefferson City Daily Capital News, October 25, 1924.

132 Jefferson City Democrat-Tribune, October 23, 1924.

${ }^{133}$ Kansas City Journal, 22 October 1924.

134 Jefferson City Democrat-Tribune, October 27, 1924.
} 
affiliation. ${ }^{135}$ Finally, as he toured the state on behalf of Republican candidates, Governor Hyde repeatedly referred to Nelson by his alleged Klan membership number, $111 . .^{136}$

As Democrats and Republicans tried to tie the other to the Invisible Empire, C.S. Burns went into hiding near his home. Outside of obituaries published after his death, little is known about Burns. His sworn affidavit shook the two political parties and his name was smeared, and celebrated, in the press. "Poor Burns!" the Jefferson City Daily Capital News declared, "he was induced by hook or crook to make an affidavit..."137 When asked to comment on his allegations, Burns simply told the press that "the affidavit speaks for itself."138 At the time that his affidavit, Burns was a forty-one year old tenant farmer from Syracuse, Missouri. He had lived in the area his entire life, was married with five children, and, as many newspapers noted, was a Republican. He joined the $\mathrm{Ku}$ Klux Klan sometime in the early 1920s, but by 1924 he was no longer in the Invisible Empire. ${ }^{139}$ Though his time in the Klan was brief, Burns no doubt learned the group's rules, regulations, and secrets while donning the robes and hood. This knowledge of the Klan may have contributed to his own fears of retaliation after his accusations against Nelson went public. When threats, including at least one letter labeled "KKK," arrived at the homes of Burns, Morris, and Collins; all three men reacted by arming themselves and

\footnotetext{
${ }^{135}$ Kansas City Star, October 22, 1924.

136 Jefferson City Democrat-Tribune, October 25, 1924.

137 Jefferson City Daily Capital News, October 29, 1924.

138 Jefferson City Democrat-Tribune, October 22, 1924.

${ }^{139}$ Kansas City Star, October 22, 1924; Versailles Statesman, November 13, 1924.
} 
seeking the assistance of friends. In the midst of these threats, Burns' wife told the press that he feared for his life and safety. ${ }^{140}$

With a little more than a week remaining until the Election, Democrats desperately tried to shift the gubernatorial campaign back to its origin focus: land values, taxation, and the Republican Party's failure to properly address both during the Hyde administration. But, Democrats and the press still managed to continually bring up the Ku Klux Klan. ${ }^{141}$ As the Jefferson City Daily Capital News, attempting to discuss the other issues of the campaign, put it: "Most decidedly, the issue is NOT whether Arthur W. Nelson, in company with friends, attended, largely out of curiosity, a meeting of the $\mathrm{Ku}$ Klux Klan, held in the open air, in California, Missouri, in June, 1923, regardless of whether one C.S. Burns makes any affidavits or not."142

Failing to move the theme of the campaign back to the original issues, the Democrats sought out Klan opponents to defend Nelson's character. Congressman Harry Hawes, who declared "I will not vote for Dr. Nelson or any other candidate for office who I believe is a klansman [sic]" when the affidavit news first broke, soon began to speak favorably of Nelson. ${ }^{143}$ Henry Priest, former Democratic gubernatorial candidate and a known anti-Klan politician, expressed his belief that Nelson was being truthful in

140 Kansas City Journal-Post, November 9, 1924; St. Louis Globe Democrat, November 9, 1924; Versailles Statesman, November 13, 1924; Kansas City Star, October 22, 1924; Large, The "Invisible Empire" and Missouri Politics, 108-109.

${ }^{141}$ St. Louis Globe Democrat, November 4, 1924; Jefferson City Daily Capital News, October 29, 1924, October 30, 1924; Kansas City Journal-Post, October 26, 1924, October 27, 1924, October 31, 1924; Large, The "Invisible Empire" and Missouri Politics, 86-128.

142 Jefferson City Daily Capital News, October 26, 1924.

143 Kansas City Star, October 21, 1924; St. Louis Post-Dispatch, October 21, 1924; Jefferson City Daily Capital News, November 2, 1924. 
the matter. ${ }^{144}$ Monsignor Timothy Dempsey, a prominent Catholic priest from St. Louis, issued a statement defending Nelson and confirming his close relationship with Nelson's family. ${ }^{145}$ H.T. Zuzak, a Jewish businessman from Cooper County, referred to Nelson as a "capable and honest official" in a letter to The Modern View. ${ }^{146}$ In reviewing the recent move by politicians and community leaders to defend Nelson, Judge A.H. Balkenbusch of Osage County told the press, "either C.S. Burns...was not telling the truth or else Ed Patterson, Dr. Gray, Senator Reed, Harry Hawes, Governor Gardner, Judge Priest, and hundreds of other prominent Missourians were lying." 147

To give the final word on the matter, the Democrats turned to the popular and fiery Senator James A. Reed to save Nelson and the Party. Reed, an outspoken opponent of the Klan, defended Nelson in a series of speeches in Kansas City, St. Louis, and Jefferson City in the final days before the Election. At each stop, he returned to the alleged Hyde-Phares Conspiracy when discussing the claims against Nelson and informed voters that he would not support Nelson if the rumors were true. ${ }^{148}$ Delivering a powerful speech at the state capitol building on the night before the election, Reed denounced the Klan and defended Nelson. "When a group of men, wrapped in sheets and pillowcases for blinders, assembled in a pasture lot under a fiery cross, Nelson went

144 Jefferson City Daily Capital News, October 30, 1924.

145 Jefferson City Daily Capital News, November 2, 1924.

146 The Modern View, 10 October 1924, 31 October 1924. Zuzak's comments in The Modern View were followed by a paid ad repeating Zuzak's defense of Nelson and co-signed by six other Jewish residents of Cooper County.

147 Jefferson City Daily Capital News, November 2, 1924.

148 St. Louis Post-Dispatch, October 29, 1924, November 2, 1924; St. Louis Globe Democrat, November 2, 1924, November 4, 1924; Jefferson City Daily Capital News, November 2, 1924. 
along with hundreds of other sight seers to witness the proceedings," Reed told the assembled crowd, "[but] when the public ceremonies were over, he went about his business...He was no more a party to that ceremony than a man that stands on the street and watches a circus parade is a member of the circus." 149

While voters and the press could question the validity of the contents of an unknown page in an unknown book in an unknown location, it was much harder to find the truth when both the accuser and the accused admitted to being at the same place at the same time. It may not have been as damning in 1924 for one to say they heard a Klan lecture. In fact, it is quite possible that a large percentage of Missouri voters heard a lecture on the Ku Klux Klan at some point between 1921 and 1924. Yet, A.W. Nelson's inability to separate fact from fiction, in the eyes of Missouri voters, contributed to his ultimate defeat in 1924. Did he really meet the Imperial Wizard in Jasper County? Was he initiated as a Klansman in 1923? Did his name really appear in the Tipton Klan ledger book? The answer to these questions may never be known, but it is nevertheless evident that the allegations that Nelson held Klan membership doomed his gubernatorial campaign and that the Klan issue significantly impacted the 1924 Election at the national, state, and local level.

The tension of the gubernatorial election continued through early November as the votes came in. In the presidential race, Calvin Coolidge easily won re-election in 1924 despite taking no specific stance on the Klan. "Silent Cal" held his tongue on the Klan issue and allowed his opponents, Democrat John W. Davis and Progressive Robert

149 Jefferson City Daily Capital News, November 4, 1924; Jefferson City Democrat-Tribune, November 4, 1924. 
LaFollette, to do all the talking for him as they made sure that the electorate knew of their opposition to the Klan. Touting Coolidge's stand on immigration reform and prohibition, hooded leaders advised their members to vote Republican for president even if individual klaverns favored Democrats at the state or local level. ${ }^{150}$ While it soon became evident that Coolidge would continue on as president, Missourians waited anxiously throughout the week to find out who would become the next governor. Though the results awaited confirmation, the St. Louis Globe Democrat quickly declared that Nelson had little chance of catching Baker. ${ }^{151}$ By November 7th, the Jefferson City Daily Capital News reported that while there were still 157 precincts still unaccounted, Nelson had won more counties than Baker and had a small lead in Kansas City. Despite claiming fewer counties, Baker overwhelmingly won St. Louis, a city that Nelson rarely bothered to visit during the campaign. In the end, Baker's margin of victory in St. Louis propelled him to the Governor's Mansion. ${ }^{152}$

On the evening of November 7, 1924, as the few remaining gubernatorial votes were tallied, the family of C.S. Burns prepared for bed. Amid the nightly routine, Raymond Burns reached for his shotgun. He closely inspected it then checked to see if it was loaded. It was during this inspection that Raymond's weapon discharged. The contents of the barrel struck his father, C.S. Burns, in the chest. The family quickly sent for a doctor, but it was too late. The elder Burns was dead. By morning, news of Burns' death had circulated around the nearby town of Syracuse, Missouri, and in to surrounding

\footnotetext{
${ }^{150}$ McVeigh, The Rise of the Ku Klux Klan, 183-188; Chalmers, Hooded Americanism, 213-215.

${ }^{151}$ St. Louis Globe Democrat, November 6, 1924.

152 Jefferson City Daily Capital News, November 7, 1924.
} 
counties. Within the span of a week, people throughout Missouri, and even parts of Arkansas, knew about the unfortunate accident that claimed Burns' life. ${ }^{153}$ "The fatality was due indirectly to the recent episode of the affidavit affecting Nelson," the St. Louis Post-Dispatch told its readers, "but for that, the gun, in all probability, would not have been in use at the Burns home." 154

The death of C.S. Burns provides perhaps the most extreme outcome of the Klan issue in the 1924 election. His death was the result of an accidental shooting, but the circumstances surrounding it, primarily Burns' fear of Klan retaliation, are nevertheless noteworthy. Though his opponents attacked the secretive nature under which his affidavit came about, Burns' story offers an important window into the circumstances surrounding the exit of a person from the Invisible Empire. At some point, whether it was philosophical or financial, Burns decided that the Klan was not for him. While others would try to tear off the robes and hoods of fellow members on their way out of the organization, Burns left relatively quietly - until 1924. Burns' decision to speak out against the Klan, as a former Klansman, was not unusual, but the significance of his words and allegations had a major impact on Missouri politics.

C.S. Burns' public affidavit provides just one example of the Klan issue, but combined with the discussion of the Invisible Empire at the municipal, county, state, and national level, it becomes obvious that the Klan issue weighed heavily on the minds of individual voters as well as members of different political parties. As much as these

153 Joplin Globe, November 9, 1924; Kansas City Journal-Post, November 9, 1924; St. Louis PostDispatch, November 9, 1924; St. Louis Globe Democrat, November 9, 1924; Jefferson City DemocratTribune, November 10, 1924; Versailles Statesman, November 13, 1924; Tipton Times, November 14, 1924; Missouri Kourier, November 21, 1924.

${ }^{154}$ St. Louis Post-Dispatch, November 9, 1924. 
political brokers wanted to shift the focus to agriculture, law enforcement, taxation, or corruption, the topic always came back to the Ku Klux Klan. In part this was the presses doing, but they were answering the demands of potential voters. While there was a multitude of issues that concerned these voters, they also cared deeply about the presumed power of the Invisible Empire, whether it was night riding vigilantism or the potential Klan-sympathies of political candidates.

Though the Klan was successful in some localities in Missouri, when Election Day arrived, the hooded order suffered a stiff repudiation at the polls in many state-level campaigns. Besides losing the governorship, the Klan's preferred candidates for Lieutenant Governor and Secretary of State were also defeated. The Klan did have some success when James T. Blair was defeated in his quest to retain his position on the State Supreme Court, but his opponent, Frank Atwood, also held anti-Klan sentiments despite earning the Klan's support. Similarly, the Klan favored both candidates in the campaigns for Auditor and Attorney General so it is difficult to judge how much advantage the hooded order had in the victories of L.D. Thompson and Robert Otto, especially since Thompson earned a "recommended" endorsement from the NAACP. ${ }^{155}$

This rejection was not the final nail in the Klan's coffin, but the organization emerged from the 1924 elections severely fractured. The commands of senior Klan officials to vote for certain candidates did not sit well with some Klansmen and -women who favored more local autonomy. This last point is extremely important for the state of Missouri. Press reports from Klan informants showed an overwhelming support among Missouri Klan officials for Democrat A.W. Nelson, especially in Kansas City and St.

${ }^{155}$ Large, The "Invisible Empire" and Missouri Politics, 154-156. 
Joseph. ${ }^{156}$ Yet despite the tremendous Klan support for Nelson, Republican Klansmen expressed concerns that the hooded order was not following its non-partisan stance.

Tensions soon arose within local chapters as Klansmen were advised which candidates to vote for in the municipal, county, state, and federal elections. ${ }^{157}$ As a result, the anger, frustration, and disillusionment of many Klansmen and -women boiled over in 1925. The hooded order may have been partially rejected nationwide as voters went to the polls in 1924, but the rollback of the Ku Klux Klan was only just beginning. With scandals involving prominent Klansmen filling the front pages of newspapers around the country, as well as little to show for in terms of political power in the wake of the 1924 election, Klan supporters, especially in Missouri, began to flee the Invisible Empire.

156 St. Louis Globe Democrat, November 4, 1924.

157 Kansas City Journal-Post, October 26, 1924, October 27, 1924; St. Louis Globe Democrat, November 4, 1924; Missouri Valley Independent, October 30, 1924; Large, The "Invisible Empire" and Missouri Politics, 154-156. 


\section{Chapter 6: "Seeds of Death"}

Dressed in a royal purple robe and flanked by a group of high-ranking Klan officials, Imperial Wizard Hiram Evans proudly marched down Washington D.C.'s Pennsylvania Avenue in August 1925. Behind him, despite the stifling summer heat, Klansmen and -women from all over the United States followed in a lengthy procession that lasted several hours. There were rumors that hundreds of thousands of members of the Invisible Empire would participate in the parade and that it would be one of the grandest events Washington D.C. had ever seen - outside of a presidential inauguration. Yet, though Klan members filled up all available lodging accommodations - some even camping on the side of the road - the masses that were supposed to show the Klan's might never arrived. Instead, while Klan members certainly made their presence felt in the nation's capital, the parade procession only numbered around forty thousand. An impressive display nonetheless, but the crowd was much smaller than expected.

Historian Thomas Pegram notes that defections and internal divisions within state Klans, particularly in Texas and Indiana, led to some states sending small delegations to Washington D.C. Even the President of the United States, Calvin Coolidge, who many Klan members felt occupied the White House thanks to their political activism, found a way to be conspicuously absent when the Invisible Empire came to town. ${ }^{1}$

In Jefferson City, Missouri, rumors swirled that John P. Gordon, an insurance salesman and former State Auditor, was on his way to the Washington D.C. event as the

\footnotetext{
${ }^{1}$ Pegram, One Hundred Percent American, 185; Chalmers, Hooded Americanism, 285-288.
} 
local klavern's designated representative. This revelation came as a suprise to Gordon, and he denied that he was on his way to the nation's capital. "I have not the remotest idea of attending the Washington conference," he confessed to reporters, "I do not intend to attend any other meeting of the Ku Klux Klan." When asked to clarify his remarks, Gordon was blunt: "I see no need for further existence of the klan [sic] as now operated." Gordon's response surprised many residents of Jefferson City. Since the Klan had first arrived in the capitol city, Gordon had never shied away from admitting his membership in the hooded order. Now, when asked about his affiliation with the Klan, Gordon informed the press that was "not a member" and would not attend the upcoming parade. When pressed by reporters to state what severed his ties to the Klan, Gordon gave a frank portrayal of life in the Invisible Empire:

Like thousands of others, I was led into the Klan by misrepresentation of its policies and purposes. Until I discovered its evil tendencies, I made no concealment of my membership in the organization. Now since I have become convinced that its practices are opposed to good citizenship and good government, I shall, with equal frankness announce that I am no longer affiliated with the $\mathrm{Ku}$ Klux Klan. Misrepresentation and misguided zeal have brought thousands of good men and women into the organization but I am constrained to believe that they will abandon it when they realize its evil trend...I will say that the klan [sic] was claimed to be founded upon the splendid principle of assisting, in a lawful way, the enforcement of the law and making communities better places in which to live and raise our families. This exalted principle has been lost sight of and the efforts of the organization turned to arousing strife and hatred, to the end that good men and women may be drawn into the organization. Assisting in law enforcement has dwindled into a mere side line, and the main efforts are devoted to playing small poltiies [sic] and dividing communities into warring factions. ${ }^{2}$

${ }^{2}$ Jefferson City Tribune, 25 July 1925. 
The Jefferson City Tribune congratulated Gordon for finally casting off the robe and hood. Approving of his comment that men and women would abandon the Klan when they realized its true intentions, the newspaper assured its readers that "the Klan is doomed in Jefferson City because it has been found out." The Tribune had never shied away from a fight with the Invisible Empire, and it took the opportunity of Gordon's exodus to disparage the Klan once more: "The men who organized it wanted $\$ 10$ and they were willing to throw a whole community into the throes of religious hatred and strife to enrich themselves... a thing like the klan [sic] couldn't live long in free America." The newspaper, however, was not yet ready to write the Klan's obituary. Instead, it reminded its readers of the late Senator Robert LaFollette's warning that the Klan had the "seeds of death within itself." "The seed," the Tribune concluded, "is sprouting." 3

In the wake of the 1924 Election, the Ku Klux Klan found itself on unstable ground. While the organization found success in communities in Indiana and Colorado, among others, states like Missouri rejected the Invisible Empire and refused to elect high profile candidates that were sympathetic to the Klan. ${ }^{4}$ Despite the sting of defeat, the Missouri Klan refused to admit that it was on the path to irrelevance. Appointed as the new Grand Dragon of Missouri, and recently re-elected as the Exalted Cyclops of St. Joseph Klan No. 4, William Campbell entered 1925 with the goal of revitalizing and

\footnotetext{
3 Jefferson City Tribune, 27 July 1925.

${ }^{4}$ Pegram, One Hundred Percent American, 186-216; Moore, Citizen Klansmen, 151-181.
} 
expanding the Invisible Empire in the state. ${ }^{5}$ Within his own community, Campbell had little to worry about the scale of the Klan. St. Joseph not only boasted one of the largest klaverns in the state, but it also held chapters of the WKKK, Kamelia, and Junior Klan. ${ }^{6}$ Additionally, the local Klan also held weekly events in St. Joseph and utilized the Missouri Valley Independent to broadcast the principles of Klankraft across Missouri, Iowa, Nebraska, and Kansas. As he singlehandedly became the highest ranking Klansman in Missouri, Campbell relied more and more on the Independent to assure fellow members that the Invisible Empire was growing by the day and that the "decline" rhetoric voiced by Klan opponents, particularly the press, was out of touch with the "real" trajectory of the hooded order. ${ }^{7}$

To counter claims of the Klan's decline, Grand Dragon William Campbell soon embarked on an ambitious "reclamation" plan to bring old and new members back to the group. The state organization was greatly aided in its quest on two fronts. First, despite assurances from some state representatives that they would push for new anti-Klan bills in the Missouri General Assembly, newly elected Governor Sam A. Baker indicated that he had no intention of backing such legislation. ${ }^{8}$ Second, Imperial Wizard Hiram Evans selected St. Louis for several Klan events, including a well-publicized, though eventually

\footnotetext{
${ }^{5}$ Missouri Valley Independent, 15 January 1925, 14 May 1925.

${ }^{6}$ Missouri Valley Independent, 12 February 1925, 28 May 1925. In most issues of the Missouri Valley Independent, a list of meeting locations and dates for various Klan groups was printed on the front page.

${ }^{7}$ Missouri Valley Independent, 13 August 1925, 4 March 1926, 3 June 1926, 17 June 1926, 8 July 1926, 15 July 1926, 22 July 1926, 29 July 1926, 5 August 1926, 12 August 1926, 19 August 1926, 9 September 1926.

${ }^{8}$ St. Louis Post-Dispatch, 8 January 1925; Jefferson City Daily Capital News, 3 February 1925; Jefferson City Daily Post, 3 February 1925; Missouri Valley Independent, 15 January 1925.
} 
cancelled, parade in 1926 and the annual meeting of the Women of the Ku Klux Klan in 1927. ${ }^{9}$ With Klan officials turning their eyes to Missouri, Campbell felt confident that his visits to klaverns across the state would galvanize support for the order. By creating a series of provincial meetings, Campbell hoped to draw attention to the Klan's work from members and non-members by setting up rallies with music, parades, and speakers. ${ }^{10}$ Though, these provincial meetings were not devoid of the Klan's usual fiery rhetoric as Campbell told those assembled that there was a "danger of our great 'melting pot' degenerating into a 'garbage can' unless American citizens keep on the alert to prevent it." 11

From an attendance standpoint, Campbell's reclamation plan was a rousing success. The provincial meetings drew thousands of Klan members from different corners of the state, and once there, they gave their unwavering support to Campbell. ${ }^{12}$ At the close of the provincial meetings and state Klorero in 1926, the Missouri Valley Independent declared that membership had increased 65\% since 1925 and that "[e]very Klansman in attendance... returned home determined to do his utmost during the coming year to erect an edifice as strong as the Rock of Gibraltar on the sturdy foundation which

\footnotetext{
${ }^{9}$ St. Louis Post-Dispatch, 19 September 1926; St. Louis Argus, 24 September 1926; St. Louis Globe-Democrat, 6 January 1927.

${ }^{10}$ Missouri Valley Independent, 3 June 1926, 17 June 1926, 8 July 1926, 15 July 1926, 22 July 1926, 29 July 1926, 5 August 1926, 12 August 1926, 9 September 1926, 5 May 1927, 12 May 1927, 21 July 1927, 4 August 1927, 11 August 1927, 18 August 1927, 13 October 1927.

${ }^{11}$ Missouri Valley Independent, 15 July 1926.

12 Missouri Valley Independent, 3 June 1926, 17 June 1926, 8 July 1926, 15 July 1926, 22 July 1926, 29 July 1926, 5 August 1926, 12 August 1926, 9 September 1926, 5 May 1927, 12 May 1927, 21 July 1927, 4 August 1927, 11 August 1927, 18 August 1927, 13 October 1927.
} 
results from the past year's efforts."13 Yet, while hooded members joined Ozark Klan No. 3, Sweet Springs Klan No. 37, New Madrid Klan No. 91, Hannibal Klan No. 111, Montgomery City Klan No. 174, and many other klaverns, the state organization proved surprisingly ineffective at mobilizing towards major social or political reform. ${ }^{14}$ Outside of a few minor victories in counties and municipalities, the Klan could claim little, if any, control over the state's governing bodies, especially the Missouri General Assembly. In fact, as the decade wore on, the Klan existed largely in name only in many communities. This point was reinforced when the Missouri Valley Independent, Campbell's Klan mouthpiece, ceased publication at the end of $1927 .{ }^{15}$ He could dismiss the rumors of the order's demise all he wanted in these years, but eventually Campbell had to concede the inevitable: internal scandals, along with electoral failures, had destroyed the Invisible Empire.

The Missouri Klan, much like the national organization, put forth a façade of strength and unity in these years, but the hooded order continued to hemorrhage members as scandals deepened during the decade. While not as damning as the accusations and admissions charged to more prominent Klansmen like D.C. Stephenson, who placed a number of politicians in key positions of power in Indiana before eventually being charged with a range of crimes including rape and murder, three notable scandals

${ }^{13}$ Missouri Valley Independent, 9 September 1926.

${ }^{14}$ Missouri Valley Independent, 23 April 1925, 12 May 1927, 30 June 1927, 25 August 1927, 13 October 1927.

15 The Fraternalist, 1 December 1927. 
involving Missouri members deeply impacted the state's hooded population. ${ }^{16}$ C.C. Crawford, local minister and editor of the St. Louis Klan-sympathetic newspaper The Patriot, defrauded subscribers in a local writing contest. The Klan, refusing to endure negative attention from the scandal, particularly in the anti-Klan press, moved to banish Crawford from the Invisible Empire. Soon after, Heber Nations, State Labor Commissioner and close advisor to Governor Arthur Hyde, found himself at the center of a graft scandal alleging that he allowed a St. Louis brewery to violate the Volstead Act. Nations endured several legal appeals in an effort to clear his name, but the scandal ruined him personally and with the Klan. Finally, Pierre Wallace, Exalted Cyclops of Ozark Klan No. 3, faced accusations of interference in municipal affairs as well as domestic violence. These revelations hurt the Klan's claims of respectability and confirmed anti-Klan fears of an "invisible government" in Jasper County.

From the periphery, the scandals involving C.C. Crawford, Heber Nations, and Pierre Wallace do not seem worthy of comparison with the crimes of D.C. Stephenson. Yet, each man found himself in situations that not only compromised his image as a respectable Klansman, but also blatantly broke the same laws that members of the Invisible Empire, as well as citizens in general, were supposed to protect, defend, and abide by. Together with allegations involving Klansmen and -women in other states, these scandals, in many ways, justified anti-Klan activists' claims that the organization was "un-American;" turned alleged hooded sympathies into political liabilities for potential candidates; and emphasized to those that had once donned the hood and robe,

\footnotetext{
${ }^{16}$ Pegram, One Hundred Percent American, 189, 201-202, 205-207; Chalmers, Hooded Americanism, 127-134, 162-174; Moore, Citizen Klansmen, 14-19, 151-183; Baker, Gospel According to the Klan, 226-231.
} 
but now were fleeing the group, that the organization was no longer the bastion of $100 \%$ Americanism that they had originally envisioned.

In Missouri, the dark clouds of scandal began with just ten words: "Let only native born American citizens enjoy the suffrage right." That short sentence won Howard K. Bowers of St. Louis a farm valued at close to $\$ 25,000$. It had all been so simple. Bowers had seen an advertisement in The Patriot, St. Louis' Klan newspaper, about a subscription contest in the fall of $1923 .{ }^{17}$ According to the ad, the author of the best slogan about Americanism would win a "beautiful Country Estate" generously donated by an "Illinois citizen who is 100 percent American every day [of] the year."18 Upon learning that he was the winner, Bowers admitted that he had little farming experience but he would rely upon his wife for agricultural advice. When asked where the farm was located, Bowers told the press that he had few specifics about the property but he believed it to be somewhere in central Illinois near Bloomington. Despite his ignorance of the rigors of agriculture, Bowers appeared ready to trade in his career in the insurance business for the life of a farmer. ${ }^{19}$ Or so it seemed.

The investigative reporters of the St. Louis Post-Dispatch, however, felt that something just did not add up about Bowers and his new farm. For starters, Bowers had recently taken a position as a clerk at a downtown office building with alleged ties to the

\footnotetext{
17 St. Louis Post-Dispatch, 15 January 1924.
}

18 The Patriot, 10 August 1923. For advertisements in The Patriot for the farm slogan contest see 10 August 1923, 17 August 1923, 24 August 1923, 6 September 1923, 21 September 1923, 28 September 1923, 5 October 1923, 11 October 1923, 17 October 1923, 25 October 1923, 1 November 1923, 8 November 1923, 15 November 1923, 6 December 1923, 12 December 1923.

${ }^{19}$ St. Louis Post-Dispatch, 15 January 1924. 
Klan. ${ }^{20}$ In further reviewing the farm story, the Post-Dispatch reported that there were at least two mortgages tied to the land in question. Mary and Lincoln Slick held these mortgages, though the Slick's admitted that a man in the "east" held another mortgage. The Slicks had owned the farm since 1912, but reporters were confused when they also found out that Lincoln Slick worked as the Circulation Manager of The Patriot. As it quickly became apparent that both the farmer owner and the farm winner were allegedly employed by the same newspaper, reporters began to dig deeper and found that the management of The Patriot had given both Lincoln Slick and Howard Bowers jobs around the same time that the farm subscription contest ended. ${ }^{21}$ When pressed for details, C.C. Crawford and Frederick Barkhurst, editors and operators of The Patriot, confessed ignorance of the entire contest. Both men initially told the press that Bowers already owned the farm. After this answer was deemed insufficient, the editors turned on each other and admitted that the other would have more information. Crawford contended that Barkhurst was in charge, while Barkhurst alleged that Crawford organized the contest. ${ }^{22}$

Despite both men pleading ignorance, the investigation soon focused on C.C. Crawford. Though he denied he ever meant to defraud anyone, Crawford's plan for the slogan contest had been a calculated money grab from the beginning. In an effort to boost subscribers and revenue for The Patriot, Crawford hired Mary and Lincoln Slick to sell subscriptions for the newspaper. Starting in August 1923, the Slicks were to employ

\footnotetext{
${ }^{20}$ St. Louis Post-Dispatch, 15 January 1924.

${ }^{21}$ St. Louis Post-Dispatch, 15 January 1924, 17 January 1924.

22 St. Louis Post-Dispatch, 15 January 1924, 17 January 1924.
} 
a group of men to scour portions of Illinois and Missouri with the goal of obtaining 100,000 new subscribers. Once they reached that goal, the Slicks would receive $\$ 100,000$ for their work with a pledge of an additional $\$ 60,000$ if they could get 200,000 subscribers. As the Patriot was conducting the slogan contest at the same time, the money the Slicks received would have easily paid off the mortgages on their farm. They could then transfer it to the contest winner. ${ }^{23}$

While Crawford and the Slicks might have envisioned a major monetary windfall from the four month slogan contest, the number of new subscribers lagged behind expectations. This failure was due in large part to the decision of postal officials to require that the contest be open to subscribers and non-subscribers. When the contest no longer had a subscription requirement, the number of new subscribers slowed to a trickle. ${ }^{24}$ By December, it became painfully obvious that the anticipated total was out of reach. With the announcement of the grand prize only weeks away, Crawford had to make a tough decision: give away the farm to the rightful winner and hope to break even financially from the fiasco, or rig the results to ensure damage control. In the end, Crawford decided to "save the klan [sic] publication." 25 He brought Lincoln Slick and Howard Bowers to his office and worked out a deal. Crawford would write out a list of possible slogans for the contest and have Bowers sign the official paperwork. Slick would then pick his favorite slogan from the list. This slogan became the official winner in the newspaper with Bowers attributed as the author. Slick and Bowers would then

\footnotetext{
${ }^{23}$ St. Louis Post-Dispatch, 15 January 1924, 17 January 1924, 7 March 1924.

${ }^{24}$ St. Louis Post-Dispatch, 7 March 1924.

${ }^{25}$ St. Louis Post-Dispatch, 7 March 1924.
} 
work out the transfer of the farm on their own, if they wanted to continue with that part of the plan. Both men, however, kept their jobs with the newspaper. ${ }^{26}$ Crawford could claim the contest was legitimate while also ensuring that the newspaper avoided financial ruin.

Everything seemed perfect until the St. Louis Post-Dispatch and officials from the Postal Service began to investigate the slogan contest. In an editorial, the Post-Dispatch declared the entire contest had been a fake and was another example of "scoundrelism cloaked under a mask of whining hypocrisy." 27 The revelation that the contest was a fraud must have been satisfying for the Post-Dispatch staff as the newspaper had been the frequent target of fiery commentaries in The Patriot. After the story broke, Crawford used nearly the entire front page of The Patriot to answer charges put forth by the PostDispatch in its "campaign of malicious propaganda." Crawford also accused the newspaper of trying "to make me out a liar" by assigning a reporter involved in the PostDispatch's coverage of the Mer Rouge Massacre to cover the story. ${ }^{28}$ The Post-Dispatch dismissed the condemnations of The Patriot, and, perhaps mocking Crawford's ministerial work, asked God to "be merciful to the deluded followers of such a cause and such a leader."29

As news about the fake contest spread, Crawford tendered his resignation as minister of the Fourth Christian Church. Despite his own admittance of lying and

\footnotetext{
${ }^{26}$ St. Louis Post-Dispatch, 7 March 1924.

27 St. Louis Post-Dispatch, 7 March 1924.

${ }^{28}$ The Patriot, 24 January 1924.

${ }^{29}$ St. Louis Post-Dispatch, 7 March 1924.
} 
defrauding potential subscribers, the church's Board of Governors refused to accept his resignation. Instead, the board passed a resolution defending Crawford and expressing confidence in his leadership. ${ }^{30}$ When reporters reminded congregants that several Klan events had taken place at the church while Crawford served as pastor, church members denied that the KKK influenced church decisions. "The attitude of the congregation is to stand by the pastor till hell freezes over, then skate around on the ice," one church member defiantly told the press. ${ }^{31}$ Given a chance to speak before his congregation, Crawford used his sermon to plead forgiveness and remind his followers that his "allegiance has always been and always will be to the Church of Christ." "If I have sinned," he told those assembled, "remember it was my eagerness to that great cause, which is second only to the cause of God." ${ }^{33}$ In spite of his connection to the scandal, Crawford's congregation forgave him and he remained the pastor of Fourth Christian Church for the rest of the 1920s. He even hosted Governor Sam Baker for the dedication of a new church building in 1926, though Baker later denied knowing about Crawford's Klan ties. ${ }^{34}$

Crawford's church may have continued to back him during and immediately after the scandal, but Klan leaders were not so eager to forgive and forget. Upon learning of the fake contest, Imperial Representative George C. McCarron began his own

\footnotetext{
${ }^{30}$ St. Louis Post-Dispatch, 8 March 1924; Missouri Fiery Cross, 13 March 1924.

${ }^{31}$ St. Louis Post-Dispatch, 8 March 1924.

${ }^{32}$ Missouri Fiery Cross, 13 March 1924.

${ }^{33}$ St. Louis Post-Dispatch, 8 March 1924.

${ }^{34}$ St. Louis Post-Dispatch, 15 November 1926.
} 
investigation into the matter. He consulted Klansman Heber Nations, and the two decided that all involved in the scandal needed a reprimand. After reviewing the statements of Bowers and Crawford, McCarron submitted information to the United States District Attorney's office about the Patriot. ${ }^{35}$ Klan members were also quick to point out that the newspaper was not an official Klan publication, though Crawford did try to sell the newspaper to the local order. ${ }^{36}$ The Klan rejected the sale and soon moved to punish Crawford. Though rumors circulated that he faced banishment from the Invisible Empire, Crawford was suspended from the Klan while the Kloncilium in Atlanta reviewed his case. ${ }^{37}$ The outcome of this hooded review is unknown, but Crawford never again served as a Klan leader in St. Louis.

C.C. Crawford's fall is important because the local Klan willingly sacrificed one of its own to save face during the scandal. Crawford was not a minor Klansmen who got into trouble. He was a well-known Protestant minister and one of the most prominent Klan supporters in St. Louis. In addition to his work with The Patriot, Crawford extensively toured Illinois and Missouri on behalf of the Klan. He was a coveted speaker who brought the message of Klankraft and Americanism to cities and small towns throughout the Mississippi River Valley. He also actively challenged Klan opponents on

\footnotetext{
${ }^{35}$ St. Louis Post-Dispatch, 7 March 1924.
}

${ }^{36}$ St. Louis Post-Dispatch, 20 March 1924, 4 May 1924; The Patriot, 27 March 1924; Klan Kourier, 1 May 1924. While trying to sell the newspaper to the Klan, Crawford temporarily changed the name from The Patriot to Missouri Fiery Cross. When the deal fell through, he changed it back to The Patriot. After the Klan sought to punish Crawford, the organization took control of the newspaper and changed its name to the Klan Kourier.

${ }^{37}$ St. Louis Post-Dispatch, 4 May 1924. 
the speaker's circuit and in the pages of The Patriot..$^{38}$ In an address nearly 2000 hooded members at St. Louis' Maxwelton Race Track, Crawford told the crowd that "I hope I will see the Ku Klux Klan march down Grand boulevard and to see the opposition press beaten to its knees." 39

It is interesting that McCarron decided to consult with Heber Nations regarding Crawford's fraud investigation because Nations faced a number of scandals of his own. In February 1924, he admitted to orchestrating the rental of the House of Representatives chamber at the Missouri State Capitol building for a Klan event. As the State Labor Commissioner, Nations' role in the incident brought denouncements from both Republicans and Democrats. ${ }^{40}$ From there, things would only get worse for Nations. Around the time of the Capitol Klan event, Heber's brother, Gus Nations, was the leader of a raid on the Griesedieck Brothers' Brewery. According to federal prohibition officials, the company brewed and sold real beer in defiance of the Volstead Act. After a series of arrests for the liquor violation, employees of the brewery admitted their crime, but also told prohibition agents that they were not the only guilty party. The brewery allegedly was part of a "protection" relationship between St. Louis brewers and state officials. Raymond Griesedieck confessed that the company had paid a state official roughly $\$ 15,000$ to ensure protection from potential raids. The brewery could produce

${ }^{38}$ The Patriot, 12 July 1923, 27 July 1923, 17 August 1923, 24 August 1923, 7 September 1923, 28 September 1923, 5 October 1923, 17 October 1923, 1 November 1923, 15 November 1923, 22 November 1923, 13 December 1923, 27 December 1923, 3 January 1924, 10 January 1924, 7 February 1924; St. Louis Post-Dispatch, 10 October 1922, 31 May 1923, 25 June 1923, 5 August 1923, 26 February 1924.

${ }^{39}$ St. Louis Post-Dispatch, 5 August 1923.

${ }^{40}$ For information on Nations' involvement with renting the House of Representatives chambers for a Klan event see St. Louis Post-Dispatch, 14 February 1924, 15 February 1924. 
real beer under the protection order, but was required to alternate between real beer and legal near beer so as not to raise suspicion. ${ }^{41}$

For the brewery and the unnamed state officials, however, their activities raised suspicion. About a month before the raid, federal agents received a tip about the brewery's real beer. After agents monitored the activities of the brewery for a short time, they realized that employees continually made phone calls to locations in Kansas City and Jefferson City. Federal investigators soon decided to wiretap buildings in both cities as well as monitor local hotels where brewery employees met with unknown individuals. News of the mysterious circumstances surrounding the Griesedieck Brothers' Brewery soon reached Washington D.C. and Assistant United States Attorney General Mabel Willebrandt. In the wake of the raid, Willebrandt ordered local officers to collect the confessions of Griesedieck employees in advance of an impending trial. ${ }^{42}$

With the Griesediecks detailing the protection plan to federal investigators, it was not long before the identities of the alleged state officials came to light. As the brewery story made headlines in Missouri, Charles Prather resigned as State Food and Drug Commissioner after a meeting with Governor Hyde and officers of the Federal Internal Revenue Department regarding the allegations that he was involved in the protection plan. Prather told the press that he resigned so he could fight the charges as a private citizen, but his departure shook the state Republican Party. Prather, according to former congressional candidate R.R. Brewster, was the "brains of the party in this State" and considered one of Hyde's most trusted advisors. A native of Advance, Prather was

\footnotetext{
${ }^{41}$ St. Louis Post-Dispatch, 9 March 1924.

42 St. Louis Post-Dispatch, 9 March 1924, 11 March 1924.
} 
appointed as Food and Drug Commissioner in 1922 by Hyde after being passed over, ironically, for a position as Missouri's Federal Prohibition Director. ${ }^{43}$

According to the St. Louis Post-Dispatch, the allegations of graft came out of nowhere like a "thundershower on a Fourth of July picnic." 44 In fact, the confessions of Griesedieck employees were so damning that Governor Hyde cancelled his planned European vacation to rush back to Missouri. Once back in Jefferson City, Hyde called on Heber Nations for some answers. After Prather's resignation, Nations' name emerged as the possible second unnamed state official connected to the protection plan. With Hyde threatening to "clear the smell of beer out of the State Capital," many expected him to fire Nations. ${ }^{45}$ Instead, Hyde kept Nations, widely considered another one of the governor's trusted advisors, as State Labor Commissioner. But, Hyde warned Nations that he would demand the commissioner's resignation if evidence connected him to the scandal. ${ }^{46}$ He did not have to wait long. In early May, Nations was indicted for his alleged role in the brewery protection plan. As Prather had done before him, Nations immediately resigned, but assured his supporters that he planned to "make vigorous war" against his accusers. ${ }^{47}$

${ }^{43}$ St. Louis Post-Dispatch, 10 March 1924, 11 March 1924; Weekly Kansas City Star, 12 March 1924.

${ }^{44}$ St. Louis Post-Dispatch, 11 March 1924.

45 St. Louis Post-Dispatch, 11 March 1924; Weekly Kansas City Star, 12 March 1924, 19 March 1924.

${ }^{46}$ St. Louis Post-Dispatch, 12 March 1924; Weekly Kansas City Star, 12 March 1924, 19 March 1924.

47 St. Louis Post-Dispatch, 7 May 1924; Weekly Kansas City Star, 14 May 1924. 
With the case headed to trial in the spring of 1925, Nations might have felt confident that Charles Prather would unite with him to fight the allegations. When Prather announced his intention to plead guilty, Nations soon realized that it would be his word against federal investigators, Griesedieck Brewery employees, and Charles Prather. ${ }^{48}$ Nations, however, was not completely alone. Gus Nations sided with his brother and agreed to serve as a possible witness for the defense. Additionally, members of the Anti-Saloon League and Woman's Christian Temperance Union initiated a letter writing campaign to pressure federal officials and President Calvin Coolidge into halting the trial. ${ }^{49}$ The press attacked such efforts on behalf of Nations. ${ }^{50}$ When the trial opened in May 1925, Charles Prather and officials of the Griesedieck Brothers’ Brewery immediately pled guilty. With members of the WCTU looking on from the gallery, Heber Nations pled not guilty. ${ }^{51}$

Having pled guilty, Charles Prather and Raymond Griesedieck became the central witnesses to the prosecution's case. Called to testify, both men discussed their encounters with Heber Nations and how the State Labor Commissioner instructed the Griesediecks to make monetary arrangements primarily with Prather because Nations was already doing a similar protection plan with another brewery. This second brewery remained anonymous, but Prather outlined how Nations received a majority of the payoff from the Griesedieck's protection arrangement. When pressed by prosecutors, the

\footnotetext{
${ }^{48}$ St. Louis Post-Dispatch, 19 April 1925.

${ }^{49}$ St. Louis Post-Dispatch, 17 May 1925, 20 May 1925, 22 May 1925.

${ }^{50}$ St. Louis Post-Dispatch, 20 May 1925, 21 May 1925, 24 May 1925; Jefferson City Tribune, 21

${ }^{51}$ St. Louis Post-Dispatch, 25 May 1925.
} May 1925. 
witnesses continually discussed how Heber Nations controlled beer protection in St. Louis due to his influence over his brother Gus, a federal prohibition agent. Perhaps trying to splinter the Nations brothers, Raymond Griesedieck testified that Heber viewed Gus as "just a kid, with no mind of his own." 52

Given a chance to cross-examine Prather and Griesedieck, Nations' defense team repeatedly inquired if either man was getting a special deal for their testimony. When the judge ruled the questioning unnecessary, Nations' attorney pressed Prather about whether Nations was ever in a meeting with the Griesediecks at the time of a money exchange. Prather acknowledged that Nations was never part of the money transactions, but he always collected his share after the meetings. ${ }^{53}$ Not getting a desired answer, and perhaps feeling the stares of WCTU members in the gallery, the defense attorney shifted the focus to Nations' dry record and asked Prather if he was aware that Nations was "as dry, if not dryer than Gus." A grin emerged on Prather's face as he replied that "Heber got dry at times." 54

With little to celebrate at the opening of the trial, the defense turned to Heber Nations to take the witness stand and clear his name. When pressed for details by both the prosecution and defense about his knowledge of the Griesedieck Brewery, Nations made a habit of slamming his hand down on the side of the witness box to punctuate his points. In his version of events, Nations was the hero seeking to keep St. Louis dry while aiding his brother Gus and other federal prohibition agents. It was not a protection plan

\footnotetext{
52 St. Louis Post-Dispatch, 26 May 1925; Kansas City Star, 26 May 1925.

${ }^{53}$ St. Louis Post-Dispatch, 26 May 1925; Kansas City Star, 26 May 1925.

${ }^{54}$ St. Louis Post-Dispatch, 26 May 1925.
} 
that he and Prather were involved in, Nations argued, but rather an organized scheme to "lay a trap" to catch the Griesedieck Brewery violating the Volstead Act. Asked about Prather's comments that he claimed a majority of the protection money, Nations flatly denied that he received bribe money. "I would say not," he loudly declared. ${ }^{55}$

In closing arguments, prosecutors compared the Nations brothers to the biblical characters Cain and Abel. Heber, serving as Cain, may not have killed his brother like his counterpart did, but he used his influence over Gus to betray him - and the law. The defense, in its own closing statement, portrayed the case as a conspiracy to ruin the Nations brothers. Both brothers visibly wept as their defense attorney accused the "enemies of law enforcement" of trying to disgrace the Nations name. ${ }^{56}$ The theory of a conspiracy against the Nations brothers put forth by the defense was not a new allegation. Heber and Gus had both made similar claims in the lead-up to, and during, the case. ${ }^{57}$ Assistant United States Attorney General Mabel Willebrandt dismissed such a charge during the trial, however, by pointing out that Raymond Griesedieck would have had every right to make a similar claim of a frame-up on the witness stand. Instead, he implicated Nations in the protection scheme..$^{58}$

Sent to their private chambers to consider the evidence of the case, the jury deliberated for nearly twenty-seven hours. Returning to the courtroom, the foreman informed the stunned gallery that the jury had found Heber Nations guilty of conspiracy

${ }^{55}$ St. Louis Post-Dispatch, 27 May 1925; Kansas City Star, 27 May 1925.

${ }^{56}$ St. Louis Post-Dispatch, 28 May 1925; Kansas City Star, 28 May 1925.

${ }^{57}$ St. Louis Post-Dispatch, 12 March 1924, 13 March 1924, 21 April 1924, 6 May 1924, 7 May 1924, 27 May 1925, 28 May 1925.

${ }^{58}$ St. Louis Post-Dispatch, 28 May 1925; Kansas City Star, 28 May 1925. 
to violate the Volstead Act. ${ }^{59}$ After analyzing the evidence of the trial and the decision of the jury, the judge sentenced Nations to eighteen months in federal prison and levied a fine of $\$ 3333 .{ }^{60}$ When asked for a statement regarding their previous show of support for the former State Labor Commissioner, the Anti-Saloon League and WCTU declined comment. ${ }^{61}$ The St. Louis Post-Dispatch, in its own review of the case, did not mince words about Nations:

Heber Nations was a bright and shining light among the leaders of the host of reformers who put over the Eighteenth Amendment and the Volstead act and who have been ardent advocates of the rigid enforcement of the prohibition laws. He was the plumed crusader of the cause of prohibition. His profession of devotion to the cause was perhaps the loudest and most insistent in the State of Missouri. His denunciation of other law breakers and of all those who opposed prohibition and the extreme methods of enforcing it was unbridled. He himself, after his indictment, is credited with 100 raids of alleged violators of the Volstead Act. He was the model of the political clergy, the pride of the Anti-Saloon League, and the pet of the W.C.T.U. His newspaper in Jefferson City was the recognized organ of high morality and law enforcement. Under Nations' cloak of righteousness, however, was the greasy hand of boodle. He had an itching palm. He used his vociferous professions of high moral purpose and civic righteousness to betray his cause and cheat the State. Under cover of zealous activity in the enforcement of the law and in the councils of prohibitionists, he entered into conspiracy to have the law violated by a brewery, and to protect the brewery in its violation of the law, for bribes. He stabbed the cause to which he professed the greatest devotion. ${ }^{62}$

\footnotetext{
${ }^{59}$ St. Louis Post-Dispatch, 30 May 1925; Kansas City Star, 29 May 1925, 1 June 1925.

${ }^{60}$ St. Louis Post-Dispatch, 1 June 1925; Kansas City Star, 1 June 1925.

${ }^{61}$ St. Louis Post-Dispatch, 30 May 1925.

62 St. Louis Post-Dispatch, 30 May 1925.
} 
Almost immediately after the guilty verdict, Nations and his defense team pushed for an appeal. ${ }^{63}$ He would get his hearing before the United States Court of Appeals in the summer of 1926, but more scandal plagued Nations in the latter half of 1925. Back in Cole County, a recently called grand jury investigated a series of controversial liquor raids undertaken by the sheriff's department and local citizens, including Heber Nations. Jefferson City residents knew of Nation's federal case and the local Tribune devoted a lengthy editorial to the active work of the Anti-Saloon League and a "certain unAmerican secret organization" in aiding Nations' defense. It was curious, the newspaper noted, that these "so-called victims," referring to the Nations brothers, were trying so hard to fight the same enforcement laws that they traditionally relied upon in their liquor raids. ${ }^{64}$ The Tribune also found it curious that Sheriff L.C. Withaup allowed Heber Nations to participate in liquor raids despite his recent conviction. Less than a month after his first trial ended, Nations accompanied Withaup and his deputies on a raid of a farm in rural Cole County. ${ }^{65}$ "To the ordinary citizen," the Tribune asserted, "it would seem that it is Nations' cue to lay low and not indulge in cleaning up until he has swept before his own door." As for his participation in the raid, the newspaper advised Withaup that "if Nations' thirst for riding is so insatiable that he cannot restrain himself...Withaup should do it for him." 66

${ }^{63}$ St. Louis Post-Dispatch, 1 June 1925, 23 September 1925.

64 Jefferson City Tribune, 22 May 1925.

65 Jefferson City Daily Capital News, 4 June 1925; Cole County Weekly Rustler, 5 June 1925; Jefferson City Tribune, 5 June 1925. For more information on Klan involvement in liquor raids see McGirr, The War on Alcohol, 132-153.

66 Jefferson City Tribune, 5 June 1925. 
Since L.C. Withaup had taken over as sheriff in 1925, area residents had voiced concerns over his use of private citizens in liquor raids. Withaup's involvement with the Klan, and his reliance upon fellow Klansmen to participate in the raids, left many to wonder who really ran the sheriff's office. This sentiment was shared by the Tribune which felt that the "loyalty of Louis to Heber is touching though strange...joined as they were by the bonds of brotherhood in the Knights of the Ku Klux Klan." ${ }^{67}$ The newspaper was concerned, however, that such a relationship threatened the enforcement of the law in Cole County. "Is the law of the klan [sic] above the law of the land?" the Tribune pondered. This question was especially pertinent after allegations surfaced that Withaup, in addition to using private citizens as part of his liquor raiding party known as the "Four Horsemen," had granted prisoners in the local jail extreme leniency when it came to their confinement. ${ }^{68}$ One prisoner later claimed that deputies allowed his to ride along on a liquor raid. ${ }^{69}$ Though the newspaper was willing to give the Withaup the benefit of the doubt when it came to these charges, it warned the sheriff that county residents had "no patience with a system which permits enforcement by a certain group of citizens...a certain secret organization." 70

While Cole County residents may have objected to Nations' participation in liquor raids, the Ku Klux Klan continued to stand behind him. At a Klan picnic on the

67 Jefferson City Tribune, 5 June 1925.

68 Jefferson City Tribune, 5 June 1925. In addition to a number of controversies surrounding his ties to the Klan and the qualifications of his deputies, Withaup was also found guilty in federal court of not properly maintaining the county jail, particularly his extreme leniency when it came to special privileges he offered prisoners. He was sentenced to a \$500 fine and probation. Jefferson City Post-Tribune, 22 November 1927, 23 November 1927, 22 December 1927.

69 Jefferson City Post-Tribune, 14 July 1927.

70 Jefferson City Tribune, 22 June 1925, 23 June 1925. 
outskirts of Jefferson City, four hundred attendees, including sheriff's department deputies, cheered as a speaker gave a rousing address expressing confidence in Heber Nations and calling upon those assembled to "do their bit toward a vindication" as he pushed for an appeal. ${ }^{71}$ Despite the show of support, however, Nations' relationship with the Invisible Empire disintegrated by the end of 1925. In November, he resigned as Exalted Cyclops of the Jefferson City klavern though he refused to clarify whether this meant he was no longer a member. ${ }^{72}$ Instead, in a public statement, Nations suggested that there was little need for a Klan in the capitol city:

There has been no quarrel between me and the Ku Klux Klan. I have only the highest respect for the men and women of Cole county who joined the organization, as I did, because we believed it the most powerful organized force for law enforcement in the community. But, the law enforcement in the community is a pretty well established fact. All of the soft drink parlors have been closed and we have elected a prosecuting attorney and sheriff who will make it hot for the law breakers. ${ }^{73}$

Out as leader of the Jefferson City Klan, Nations could now focus his sole attention on his impending appeals case. In July 1926, the United States Court of Appeals reversed Nations' conviction citing that the judge should have recused himself in the first trial because of potential bias. Though not declaring Nations innocent, the Court of Appeals left the decision to seek a new trial to federal prosecutors. ${ }^{74}$ Federal officials

${ }^{71}$ Jefferson City Tribune, 22 July 1925. Around the same time, the Jefferson City Klan also held a large outdoor memorial service for William Jennings Bryan who died in the summer of 1925 . Jefferson City Daily Capital News, 7 August 1925, 8 August 1925.

72 Jefferson City Daily Capital News, 25 November 1925; Jefferson City Tribune, 25 November 1925; Cole County Weekly Rustler, 27 November 1925.

73 Jefferson City Daily Capital News, 25 November 1925.

${ }^{74}$ St. Louis Post-Dispatch, 17 July 1926, 18 July 1926; Weekly Kansas City Star, 21 July 1926. 
pursued such an option after the United States Supreme Court ruled that it would not review the appeals court's reversal. ${ }^{75}$ When Nations' second trial came up in 1928 , prosecutors again relied on Charles Prather and Raymond Griesedieck to testify on Nations' role in the protection plan. Seeking to strengthen his defense, Heber called on his brother Gus, who was withheld as a witness originally, to testify about their efforts to suppress illegal alcohol in St. Louis. As it had done in 1925, the jury found Nations guilty of conspiracy to violate the Volstead Act. The new judge showed Nations some leniency and reduced the fine to $\$ 2000$ while still upholding the eighteen month prison sentence. ${ }^{76}$ Nations and his attorneys once more pushed for an appeal. ${ }^{77}$

In what would become a successful trend for Heber Nations, the United States Court of Appeals sided with the former State Labor Commissioner in 1929 and 1931 in his bid for a retrial. ${ }^{78}$ The Court of Appeals ruled in both hearings that evidence was withheld in 1928 and again at Nations' third trial in 1930. By 1930, the trial and the Great Depression were taking a serious toll on Nations. He admitted that he had moved from Jefferson City to Farmington since the second appeal and had a hard time finding work due to the country's economic troubles and his own damaged reputation. ${ }^{79}$ When federal prosecutors again used Charles Prather and Raymond Griesedieck to connect Nations to the beer protection plan, the former Klan leader lashed out on the witness

${ }^{75}$ St. Louis Post-Dispatch, 8 August 1926, 29 November 1926.

${ }^{76}$ St. Louis Post-Dispatch, 24 January 1928, 25 January 1928, 26 January 1928, 27 January 1928, 28 January 1928, 20 February 1928.

77 St. Louis Post-Dispatch, 20 February 1928.

${ }^{78}$ St. Louis Post-Dispatch, 22 April 1929, 6 August 1931.

${ }^{79}$ St. Louis Post-Dispatch, 22 April 1929, 11 January 1930, 12 January 1930. 
stand questioning the motives of the district attorney on why he was the target while guilty men like Prather and Griesedieck faced little punishment. ${ }^{80}$ Despite an impassioned plea for leniency, and the testimony of several current and former state officials brought in to vouch for his character, Nations was again found guilty of conspiracy to violate the Volstead Act. ${ }^{81}$

When Nations won his third appeal in 1931, federal prosecutors debated the merits of a fourth trial. Though the St. Louis Post-Dispatch demanded that the prosecution finish what it started, the decision on a fourth trial stalled as the calendar turned to $1932 .{ }^{82}$ After three successful convictions, the prosecution knew it still had a strong case, but the world was a much different place in 1932 than it had been in 1925 . By the early 1930s, sentiment against the $18^{\text {th }}$ Amendment had grown stronger as the Depression deepened. Additionally, key witness Raymond Griesedieck had died. When asked if the prosecution would pursue a fourth trial, federal officials declined. The case was not justified, prosecutors told the press, because "the eighteenth amendment is now on its last legs." ${ }^{83}$ Heber Nations was a free man, but little was left of the Invisible Empire.

${ }^{80}$ St. Louis Post-Dispatch, 8 January 1930, 9 January 1930, 11 January 1930, 12 January 1930, 13 January 1930. While Raymond Griesedieck died before his sentencing, the Griesedieck Brothers Brewery was fined $\$ 10,000$ for its role in the beer protection scandal. Federal prosecutors used Prather's guilty plea and possible sentence as leverage for his continued testimony. He was eventually fined $\$ 500$. St. Louis Post-Dispatch, 1 July 1933, 2 July 1933, 16 October 1933.

81 St. Louis Post-Dispatch, 13 January 1930, 15 January 1930, 16 January 1930. At his third trial, Nations relied on Charles M. Hay, former chairman of the Democratic State Convention; Charles Becker, Missouri Secretary of State; L.D. Thompson, State Auditor; and William C. Irwin, former State Senator, to defend his character.

82 St. Louis Post-Dispatch, 13 August 1931.

${ }^{83}$ St. Louis Post-Dispatch, 16 October 1933. 
One Klansman who also felt the sting of public pressure, but did not live long enough to see the end of Heber Nations's legal campaign was Pierre Wallace. Born in Webb City in 1887, Wallace lived his entire life in Jasper County. After completing an education in the local school system, Wallace worked in the tobacco business for close to twenty-five years, including a period as the manager of the Joplin Tobacco Company. ${ }^{84}$ In addition to his role in the business community, Wallace was also active, along with his wife Flora, in the Parent-Teacher Associations of Jasper County. Flora Wallace even served as president of the Webb City PTA and on the state board of Parent-Teacher Associations. ${ }^{85}$ When the Klan came to the county in 1921 , Wallace became one of the organization's most vocal supporters and used his standing in the community to rise to the rank of Exalted Cyclops. ${ }^{86}$

In donning the white robes, Wallace hoped to make the local Klan into both a philanthropic organization, as evident by numerous hooded donations to local schools, as well as a powerful political machine. ${ }^{87}$ Such an opportunity presented itself in the administration of Taylor Snapp. Though the Klan issue had not dominated his initial Joplin mayoral campaign in 1922, the hooded order quickly tied itself to Snapp. As a result, multiple anti-Klan organizations soon emerged in Jasper County to counter the Klan's political strength. At first, Snapp, Wallace, and Ozark Klan No. 3 kept anti-Klan

84 Joplin Globe, 16 July 1929, 27 July 1929.

85 Joplin Globe, 30 October 1921, 7 February 1923, 8 February 1923, 20 January 1924, 5 October 1924, 23 November 1924,

${ }^{86}$ Joplin Globe, 16 July 1929, 27 July 1929.

87 Joplin Globe, 18 April 1922, 17 September 1922, 22 September 1922, 5 October 1922, 12 November 1922, 3 March 1923, 12 May 1923, 12 September 1923, 13 March 1924, 15 March 1924, 4 May 1924, 15 March 1925, 13 December 1925, 21 November 1926. 
power at bay. Yet, just as the national Klan entered a period of decline following the 1924 Election, so too did Jasper County Klansmen experience a similar collapse, especially Exalted Cyclops Pierre Wallace.

As 1925 dawned in Jasper County, Pierre Wallace could claim quite a bit of power over Ozark Klan No. 3. He also continued to have influence over Jasper County. Sheriff Guy T. Humes appointed Wallace as one of his deputies in January. Though it was an unpaid position, the local press hinted that Humes answered to Wallace, and not the other way around.$^{88}$ However, soon after, Wallace mysteriously separated from the Klan. No clear explanation of his ouster was given because Jasper County newspapers did not cover the story as the press in Jefferson City did over the exodus of John P. Gordon and Heber Nations. It is unknown if he was forced out or voluntarily stepped down. The records of JAKO, CAKA, and JCAKA also offer little indication about what occurred within the rank and file of the hooded order. Nevertheless, Wallace's life took a notable turn from the moment he left the Klan. His wife later claimed that Wallace began to drink heavily following his departure from the Klan. Added to this, he lost his managerial job in 1927 when the Joplin Tobacco Company closed down. Wallace recovered slightly from economic disaster by finding work in the insurance business, but his heavy drinking did not subside as the decade wore on. ${ }^{89}$

Perhaps the biggest scandal connected to Wallace was an allegation put forth by a former police officer that the Exalted Cyclops controlled Joplin's city hall during the Snapp administration. While Snapp never openly campaigned in favor of the Klan, he

\footnotetext{
88 Joplin Globe, 14 April 1926.

89 Joplin Globe, 16 July 1929, 27 July 1929.
} 
was not one to turn down hooded support. When he ran for re-election in 1926, the newly unified Jasper County Anti-Klan Association mounted a full scale effort to elect J.F. Osborne over Snapp. A Joplin resident for over 30 years, Osborne had risen from a young local attorney to a four-time mayor of the city. ${ }^{90}$ While Osborne assured voters that the Klan would no longer influence municipal affairs, the police officer's affidavit proved to be the fatal blow to both Snapp and Wallace.

The Globe considered the mayoral race between J.F. Osborne and Taylor Snapp to be "the most bitter and strenuous campaign of [Osborne's] career."91 Though both men were well respected in the community, the campaign soured with the injection of the Klan issue. Since his election in 1922, anti-Klan supporters charged that the Klan had Snapp's ear. Such allegations gained traction as the Invisible Empire experienced its greatest period of growth and success in Joplin during Snapp's administration. The Joplin Anti-Klan Organization (JAKO) campaigned against this alleged "invisible" government during the 1924 municipal elections, but with little success. Now faced with the prospect of four more years of Snapp leadership, Joplin's anti-Klan forces sprang forth in a counter attack and approached Osborne about running for mayor. He had retired when his term concluded in 1922, but the growing influence of the Klan in Jasper County convinced Osborne to try his luck once more in $1926 .{ }^{92}$ Initially, Osborne framed his campaign as an effort to establish law and order in Joplin by reforming the corruption allegedly undertaken by the local police department. Osborne wanted Joplin to be the

\footnotetext{
90 Joplin Globe, 4 November 1926.

91 Joplin Globe, 4 November 1926.

92 Joplin Globe, 4 November 1926, 7 February 1926.
} 
“"Gateway to the Ozarks'...not the gateway to jail." ${ }^{\text {"93 }}$ Not surprisingly, Osborne's words received strong pushback from local law enforcement, particularly those associated with the Snapp administration. ${ }^{94}$

While the issue of law enforcement corruption emerged as the central theme early in the campaign, Osborne also realized that the Klan's control of Jasper County needed to emerge as a key talking point. At first, he only referenced the Klan by implying that residents wanted city hall "free from the domination of sinister influences from the outside. ${ }^{95}$ But as Snapp supporters bit back against charges of police corruption, Osborne laid the issue bare: "I am not a Klansman, never have been, and never will be...I am opposed by the Klan, and I oppose the Klan and its insidious meddling in municipal affairs." 96 Osborne went on to claim that "people know things are wrong at city hall; and they have now to say whether the bold intermeddling and dictatorship there of the Boss from Webb City is to be approved for another term."${ }^{.97}$

Osborne's comments linking the Snapp administration to the "Boss from Webb City" would have been quite clear to Joplin residents. Though the Klan was an alleged secret society, people throughout Jasper County knew that Pierre Wallace was the Exalted Cyclops of Ozark Klan No. 3. What these potential voters were not prepared for was definitive proof that Wallace controlled local affairs. Only days before the municipal

\footnotetext{
${ }^{93}$ Joplin Globe, 7 March 1926.

${ }_{94}$ Joplin Globe, 2 April 1926, 4 April 1926.

${ }^{95}$ Joplin Globe, 7 March 1926.

${ }^{96}$ Joplin Globe, 4 April 1926.

${ }^{97}$ Joplin Globe, 4 April 1926.
} 
election, a former Joplin police officer went on record with evidence alleging that Snapp and Wallace had personally reviewed a case involving him that eventually led to his dismissal from the police force. ${ }^{98}$ While Snapp had a right to investigate the case, Wallace's attendance would have raised eyebrows as he was not a member of the local police department or city government. The officer's allegations, signed by a notary public, placed the head of the local Klan and the mayor in the same room reviewing city affairs. Ultimately, the officer implied that the mayor fired him for doing his job: enforcing prohibition laws. ${ }^{99}$

The publication of the affidavit left Snapp supporters and Ozark Klan No. 3 with little time to respond. Instead, voters went to the polls with an image in their minds of Snapp and Wallace side-by-side. In the end, the allegations of police corruption and Klan ties in the Snapp administration, combined with Osborne's own political record, produced a victory for the former mayor. But, it was not just Osborne that won on Election Day. The Joplin press noted a decided repudiation of the Klan in the outcome of the municipal election, particularly the mayoral race and the school board campaigns. Only one Klan-backed candidate won, and even he was deemed "acceptable" by antiKlan supporters. ${ }^{100}$

Soon after his victory, Osborne moved quickly to cleanse Joplin of the Klan. He expressed the expectation that city workers would show loyalty to the new

98 Joplin Globe, 6 April 1926. According to Glenn Skoggman, his firing related to leaving his beat to visit a local rooming house. In his defense, Skoggman claimed that fellow officers ordered him to stop at the rooming house. When he arrived, three other officers corned him and told him to stop investigating alcohol-related offenses at local drug stores.

99 Joplin Globe, 6 April 1926.

100 Joplin Globe, 7 April 1926. 
administration, but Osborne explicitly demanded that anyone who sided with the Klan in the municipal election should resign. He also filled open city positions with bipartisan allies, including a few who had ties to the Jasper County Anti-Klan Association. ${ }^{101}$ However, Osborne's moves faced opposition in the city council as well as the fire department. When Osborne opted to demote Fire Chief Henry Wondell because of his close ties to the Klan, the city council investigated the matter and local firemen threatened a walkout. Not satisfied with the council's handling of the situation, Osborne demoted the Fire Chief citing that "Mr. Wondell's membership and active participation in klan [sic] activities precluded me from considering him as a member of my cabinet." Soon after, twenty-nine firemen and five police officers resigned in protest. ${ }^{103}$ While not all of them held ties to the Invisible Empire, Osborne, and his anti-Klan supporters, never forgot the walkout and continued to purge city officials tied to the former administration citing that "no man could hold office under Snapp who did not belong to the Ku Klux Klan."104

Osbourne's victory in the mayoral campaign galvanized anti-Klan sentiments throughout Jasper County. Pressed by concerned citizens, many political candidates began to speak out against the hooded order as the 1926 general election drew near. By November, roughly twenty candidates campaigning for offices ranging from Constable to

101 Joplin Globe, 10 April 1926, 11 April 1926.

102 Joplin Globe, 11 April 1926, 13 April 1926, 14 April 1926, 15 April 1926, 17 April 1926, 18 April 1926, 20 April 1926.

103 Joplin Globe, 11 April 1926, 13 April 1926, 14 April 1926, 15 April 1926, 17 April 1926, 18 April 1926, 20 April 1926.

104 Joplin Globe, 3 July 1926. 
Congressman publicly denounced the Klan or confirmed that they were not members. ${ }^{105}$

In an editorial entitled "Frankness on the Klan," the Globe told its readers that "recent announcements by county candidates concerning their stand on the Ku Klux Klan is a development of the campaign that will be appreciated by voters." "Candidates who do not state their position against the Klan are taking chances on being accepted as klansmen [sic]," the newspaper warned. ${ }^{106}$ However, despite active attempts to turn voters against candidates with Klan ties, the Jasper County Anti-Klan Association experienced mixed success on Election Day. ${ }^{107}$ Yet, though the JCAKA could not tout a rout of Klan forces in the county, it was nevertheless apparent that the wave of anti-Klan sentiment had continued from the spring mayoral election through the general election. Added to this, the Klan was rejected once more in December 1926 when Charles Patterson defeated Dr. A.B. Clark in a special mayoral election following Osborne's unexpected death. ${ }^{108}$ With an anti-Klan mayor now occupying Joplin's city hall and his own ties with the Invisible Empire severed, Pierre Wallace lived out the rest of his life in a drunken stupor. His family tried to quell Wallace's drinking, but their efforts brought physical

105 Joplin Globe, 15 July 1926, 17 July 1926, 21 July 1926, 23 July 1926, 25 July 1926, 27 July 1926, 28 July 1926, 29 July 1926, 31 July 1926, 1 August 1926, 29 October 1926, 31 October 1926. Some of the candidates who spoke on the Klan were John H. Flanigan, P.E. Donnell, Henry C. Johns, Robert W. Moore, Waldo Hatler, Frank Birkhead, A.H. Garner, Frank B. Davis, A.J. Edwards, Thomas Thoutman, J.W. Page, Joseph E. Turner, Glenn Skogman, A.M. Baird, Uriah Smith, Mrs. S.L. Bradley, Earnest A. Hart, and Grant Emerson.

106 Joplin Globe, 18 July 1926.

107 Joplin Globe, 4 August 1926, 29 October 1926, 31 October 1926, 3 November 1926, 4 November 1926. The Jasper County Anti-Klan Association mounted a particularly strong and successful challenge to the campaign of Roy Bond for Circuit Court Judge.

${ }^{108}$ For information on the Joplin special election see Joplin Globe, 7 November 1926, 9 November 1926, 11 November 1926, 16 November 1926, 23 November 1926, 3 December 1926, 5 December 1926, 8 December 1926, 9 December 1926, 11 December 1926, 12 December 1926, 14 December 1926, 16 December 1926, 17 December 1926. 
resistance. On more than one occasion, Wallace allegedly assaulted and verbally berated his wife. Wallace's son later claimed that his father "came home drunk nearly every night, except on Sundays."109 This toxic turn brought about a final clash between Wallace and his wife. In 1929, in the midst of an argument with his son, Pierre Wallace's wife gunned him down in their home. His wife claimed self-defense and argued that she feared for her son's safety. ${ }^{110}$ A coroner's jury agreed and decided to withhold charges against Flora Wallace citing that the shooting was justified. ${ }^{111}$ Wallace family attorneys concluded that “it wasn't Pierre Wallace who was killed but a man possessed by the demon, Rum."112

For men who originally donned the white robes to stamp out liquor violations, protect the home, defend white womanhood, and end government corruption, C.C. Crawford, Heber Nations, and Pierre Wallace all met their end in defiance of the very laws they swore to promote. While most of the previously highlighted incidents involved Missouri Klansmen, arguably the biggest scandal to rock the Klan nationwide involved D.C. Stephenson of Indiana. Stephenson's rise and fall is important not only because he violated laws that fellow Klansmen like Crawford, Nations, and Wallace were supposed to defend, but also because the state's anti-Klan pressed tied all of these scandals together to demonstrate the order's hooded hypocrisy. Additionally, few scholars have offered analysis about Missouri's anti-Klan Senator James A. Reed's role in investigating

\footnotetext{
109 Joplin Globe, 27 July 1929.

110 Joplin Globe, 16 July 1929.

111 Joplin Globe, 27 July 1929.

112 Joplin Globe, 27 July 1929.
} 
Stephenson and the Klan. In the end, the hearings and trials connected to Stephenson and the Klan doomed the Invisible Empire and gave further rise to Reed's political career.

One of the most powerful Klansmen in the United States, D.C. Stephenson was the unofficial leader of the Klan in Indiana. He had brought the state into the Invisible Empire in the early 1920s and made his home territory into one of the strongest regions for Klanism. His ambition greatly expanded the Klan Empire, yet his desire for power brought him at odds with Imperial Wizard Hiram Evans. Stephenson had been instrumental in removing previous Imperial Wizard William Simmons as the leader of the Klan and replacing him with Evans, but Evans and Stephenson could not co-exist in the Invisible Empire. A series of clashes between the two resulted in Stephenson's removal as Grand Dragon of the Indiana Klan, but while Walter Bossert became Indiana's new leader, Stephenson was the "law" in the state. ${ }^{113}$

As a result of Stephenson's ouster, the Indiana Klan divisively split into Bossert and Stephenson factions. The Klan still controlled the state; however the leadership divide created significant problems. While Bossert navigated the Klan towards upcoming elections, Stephenson eyed his own political career. It was in the midst of this period of maneuvering towards politics that Stephenson decided to take a group of associates, including Madge Oberholtzer, a twenty-eight year old office clerk who had recently caught his eye, to Chicago. ${ }^{114}$ On the train ride, Stephenson drank heavily and repeatedly

\footnotetext{
113 Pegram, One Hundred Percent American, 189, 201-202; Chalmers, Hooded Americanism, 162171; Moore, Citizen Klansmen, 14-19, 151-179; Baker, Gospel According to the Klan, 226-227; Blee, Women of the Klan, 94-95.

114 Pegram, One Hundred Percent American, 206; Chalmers, Hooded Americanism, 162-172; Moore, Citizen Klansmen, 151-182; Baker, Gospel According to the Klan, 226-228; Blee, Women of the Klan, 94-96.
} 
sexually assaulted Oberholtzer. Unsure about what to do with Oberholtzer, Stephenson kept her under close surveillance before relenting and allowing her to buy medical supplies. Out of Stephenson's sight, Oberholtzer bought poison, consumed it, and waited for death. ${ }^{115}$ After initially withholding medical treatment from her, Stephenson took Oberholtzer back to Indianapolis and had his lieutenants dump her lifeless body at the home of her parents. She languished in agony for a few weeks before eventually dying. Unable to testify against Stephenson in a criminal trial, Oberholtzer's deathbed confession nevertheless served as the chief piece of evidence to convict the former Grand Dragon. In November 1925, Stephenson was found guilty of murder and sentenced to life in prison. ${ }^{116}$

From his jail cell, Stephenson waited for his political allies to come to his rescue. Despite many politicians owing their electoral success to Stephenson, many state Republicans distanced themselves from him in the wake of the scandal and trial. Even Ed Jackson, whose election as governor was due in large part to Stephenson, refused to offer any significant help. When it became obvious that he would not receive the pardon he felt he deserved, Stephenson began to leak incriminating information to prominent state newspaper editors who then pushed Governor Jackson to launch an investigation. ${ }^{117}$ In response, Jackson tried to hold back the tide of allegations and control the release of

\footnotetext{
115 Pegram, One Hundred Percent American, 206; Chalmers, Hooded Americanism, 171-172; Moore, Citizen Klansmen, 181-182; Baker, Gospel According to the Klan, 226-229; Blee, Women of the Klan, 95-96.

116 Pegram, One Hundred Percent American, 206-207; Chalmers, Hooded Americanism, 171-172; Moore, Citizen Klansmen, 181-182; Baker, Gospel According to the Klan, 226-229; Blee, Women of the Klan, 95-96.

117 Pegram, One Hundred Percent American, 206-207; Chalmers, Hooded Americanism, 172-174; Moore, Citizen Klansmen, 181-183; St. Louis Post-Dispatch, 10 October 1926, 11 October 1926.
} 
possible damaging information. Fearing that Jackson's plan for committee hearings would bring a biased conclusion, advocates pushed for a congressional investigation. Since part of Stephenson's claims centered on the state's recent senatorial campaigns of James E. Watson and Arthur Robinson, the focus soon shifted to Missouri Senator James A. Reed. ${ }^{118}$

James A. Reed was nearing the end of his Senate career when the press began to call for him to investigate corruption in Indiana. At the time of the Stephenson allegations, Reed was the chairman of the Senate Campaign Fund Investigating Committee. The committee's main job was to investigate irregularities and corruption in political campaigns involving current or potential US Senators. ${ }^{119}$ Initially, Reed told the press that he was hesitant to look into the claims of graft in the Indiana Republican Party. With the general election looming in less than a month, Reed admitted that it would be difficult for all of the committee's members to meet in a set location for an extended period of time. Additionally, the election might also impact the availability of witnesses to testify. Finally, and most importantly, Reed indicated that there might not be enough available evidence to warrant a congressional investigation. ${ }^{120}$

The mere possibility of Reed probing Indiana politics sent a shockwave through the Republican Party. Even if no substantial evidence was uncovered, party leaders worried about the damage daily press updates of the investigation would do to them in

118 Pegram, One Hundred Percent American, 206-207; Chalmers, Hooded Americanism, 172-174; Moore, Citizen Klansmen, 181-183; St. Louis Post-Dispatch, 9 October 1926, 10 October 1926, 11 October 1926.

${ }^{119}$ St. Louis Post-Dispatch, 9 October 1926.

${ }^{120}$ St. Louis Post-Dispatch, 12 October 1926, 17 October 1926. 
the 1926 general election. Added to this, Reed's reputation as a fiery opponent of the Klan who frequently denounced the Invisible Empire no doubt concerned many members of the hooded order. ${ }^{121}$ However, as his name circulated in connection to a possible investigation, Reed kept quiet about the Klan. Knowing the damage his committee could do to the Republican Party and the Ku Klux Klan, Reed gave little indication of his plans for an inquiry. ${ }^{122}$ But by mid-October, Reed called his fellow committee members to a meeting in Chicago and prepared for a hearing. ${ }^{123}$

Once in Chicago, Reed's earlier concerns about election conflicts proved true. Several committee members, including William King of Utah, Robert LaFollette Jr. of Wisconsin, Charles McNary of Oregon, and Guy Goff of West Viriginia, indicated that they would be limited in participation due to their campaign schedules. ${ }^{124}$ Even without his fellow Senators, Reed immediately pushed on with the hearings alone. He called high ranking officials from both the Indiana Republican and Democratic parties to testify regarding the recent Senate primaries. There was substantial evidence to suggest that the Klan had thrown its overwhelming support behind James E. Watson and Arthur Robinson. While Watson had served in the Senate since 1917, Governor Jackson recently appointed Robinson to Congress following the death of Senator Samuel Ralston. $^{125}$

${ }^{121}$ St. Louis Post-Dispatch, 15 October 1926, 17 October 1926.

${ }^{122}$ St. Louis Post-Dispatch, 12 October 1926.

${ }^{123}$ St. Louis Post-Dispatch, 17 October 1926, 19 October 1926; Kansas City Star, 14 October 1926, 19 October 1926.

${ }^{124}$ Kansas City Star, 14 October 1926.

${ }^{125}$ St. Louis Post-Dispatch, 19 October 1926, 20 October 1926, 21 October 1926, 22 October 1926; Kansas City Star, 19 October 1926, 20 October 1926, 21 October 1926, 22 October 1926. 
Similar to many politicians in the state, both Watson and Robinson had deep ties to D.C. Stephenson and the Klan. Stephenson expressed support for Watson's re-election bid; no doubt aware of the favors he could receive from such an endorsement. Robinson, on the other hand, was a lieutenant of Stephenson. If he could not have the seat himself, Stephenson wanted to ensure that someone he could trust would fill it. As such, Robinson's election served as a de facto victory for the now incarcerated ex-grand dragon. ${ }^{126}$ After a parade of politicians and Klansmen made their way through Reed's one man jury in Chicago, it quickly became obvious that the Republican Party and the Klan had struck a bargain when it came to electing Indiana's senators. Nevertheless, Reed was cautious. The Klan could back whatever candidate it preferred for public office. That was not a crime. But, what promises or arrangements occurred to earn that support was a different matter. Reed continued to grill witnesses for several days in Chicago about the alleged bargain, but, citing pressing engagements back home, he shifted the location of the hearings to Kansas City. ${ }^{127}$

Back home in Kansas City, Reed continued the investigation while also serving as the primary political orator for the Missouri Democratic Party. Aware of his power on the campaign trail, he told the press that he wanted to wrap up the hearings as soon as possible. ${ }^{128}$ When not interrogating witnesses, Reed spent his evenings denouncing the tactics and policies of the national Republican Party. After giving speeches throughout

\footnotetext{
${ }^{126}$ Chalmers, Hooded Americanism, 169-173.

127 St. Louis Post-Dispatch, 19 October 1926, 20 October 1926, 21 October 1926, 22 October 1926, 23 October 1926, 24 October 1926; Kansas City Star, 19 October 1926, 20 October 1926, 21 October 1926, 22 October 1926, 23 October 1926.

${ }^{128}$ St. Louis Post-Dispatch, 24 October 1926.
} 
western Missouri, including one at Kansas City's Convention Hall, Reed decided to move the hearings to St. Louis so that he could give similar public addresses in that city. ${ }^{129}$ In an interesting twist, Reed's comments on the campaign trail were in favor of Missouri senatorial candidate Harry Hawes who was running against Republican George $\mathrm{H}$.

Williams, whose name had come up during the hearings. In fact, Reed repeatedly pushed witnesses to expand on why Williams' name came up in connection to Indiana politics. ${ }^{130}$ What Reed uncovered was shocking.

In one of the biggest, and perhaps oddest, moments of the hearings, Reed called on Vivian Tracy Wheatcraft to testify about her role in the campaign of James E. Watson. As the Vice Chairwoman of the Indiana Republican Committee, Wheatcraft had worked closely with Senator Watson, and Reed wanted to know about her possible connection to the Ku Klux Klan. While not listed as a prominent member of the WKKK, Wheatcraft allegedly orchestrated a statewide mobilization effort to get women to support Watson. Labeled as "poison squads" in the press, and by contemporary scholars like Kathleen Blee, these women's groups actively campaigned for Watson while also spreading vile rumors about his opponents. ${ }^{131}$ The tactic had been so successful in Indiana that rumors alleged that George H. Williams had enlisted Wheatcraft to do the same with women in Missouri for his own senatorial campaign. ${ }^{132}$

${ }^{129}$ St. Louis Post-Dispatch, 24 October 1926; Kansas City Star, 24 October 1926, 25 October 1926.

${ }^{130}$ St. Louis Post-Dispatch, 23 October 1926, 24 October 1926.

${ }^{131}$ Blee, Women of the Klan, 113-116; St. Louis Post-Dispatch, 23 October 1926, 25 October 1926; Kansas City Star, 25 October 1926.

${ }^{132}$ St. Louis Post-Dispatch, 23 October 1926, 25 October 1926. 
If Reed hoped to get Wheatcraft's side of the story, he would have to wait. Citing a severe illness, Wheatcraft's associates informed the senator that she was confined to a hospital bed and unable to testify. ${ }^{133}$ While he waited on her recovery, Reed pushed deeper into the Klan's involvement in Indiana politics. The local Klan originally intended to unite behind the state's Republican senate candidates, but pressure to do so from high ranking Klan officials in Atlanta caused a further split in the Indiana Klan. Walter Bossert, who had replaced Stephenson as the state's grand dragon, refused to support Watson. In an effort to prevent a similar schism as the Stephenson/Bossert split a few years earlier, Imperial Wizard Hiram Evans quickly removed Bossert as grand dragon and replaced him with another Klansman. With new leadership, a majority of Indiana Klansmen and -women aligned behind Watson, Robinson, and the Republicans. $^{134}$

With rumors swirling that Watson, or Robinson, or both were Klansmen, Reed brought the hearings to a conclusion at the end of October 1926. He tried once more to bring in Vivian Tracy Wheatcraft for testimony, but she had disappeared. Reed demanded answers since one of the reasons he moved the hearings to St. Louis, besides his speaking engagements, was to be closer to Wheatcraft's hospital. He soon discovered that she had left for Indiana in the middle of the night. Upon arriving in Indianapolis, Wheatcraft was quickly readmitted to a new hospital. Again, she claimed she was too

133 St. Louis Post-Dispatch, 23 October 1926, 25 October 1926, 28 October 1926.

${ }^{134}$ Chalmers, Hooded Americanism, 169-173; Moore, Citizen Klansmen, 151-181; St. Louis PostDispatch, 24 October 1926, 28 October 1926; Kansas City Star, 25 October 1926. 
sick to testify. ${ }^{135}$ Without Wheatcraft, Reed could not investigate possible connections between the political influence of Indiana's poison squads and their sisters in Missouri. With the election drawing near, Reed halted the hearings for the foreseeable future. ${ }^{136}$ Though he was unable to draw a direct connection between the Indiana and Missouri Klans, Reed's hearings nevertheless severely damaged Stephenson and the Invisible Empire. Reed also used his role as a Senate corruption investigator to build a strong, yet ultimately unsuccessful, campaign for the White House in 1928 as a candidate who favored states' rights, honest government, and agricultural relief.

The ever-growing list of Klan scandals, combined with a continued poor showing at the ballot box, served as perhaps the biggest point of repudiation of the Klan in Missouri and nationwide. Surveying the victory of Charles Patterson and the notable anti-Klan wave of politics in Jasper County, the Joplin Globe reminded its readers that "support of the Ku Klux Klan is a political liability instead of an asset."137 In Kansas City, the Catholic Register reported that the Klan had faded to "little more than a negligible quality in politics." 138 The scandals of Klan officials, both inside and outside of politics, were equivalent to gang activity according to the St. Louis Argus which assured its readers that "like all other gangs of criminals, they can be broken up if the leaders are caught and imprisoned."139 The Kansas City Call shared the sentiment and

135 St. Louis Post-Dispatch, 28 October 1926, 1 November 1926; Kansas City Star, 25 October 1926.

${ }^{136}$ St. Louis Post-Dispatch, 29 October 1926.

137 Joplin Globe, 18 December 1926.

138 Kansas City Catholic Register, 16 February 1928.

${ }^{139}$ St. Louis Argus, 8 July 1927. 
soon declared "goodbye nightshirt" because "the Invisible Empire [was becoming] invisible indeed." 140

Whereas the anti-Klan press had had a penchant for prematurely declaring the hooded order's demise in the past, the years following the 1924 election served as one of the darkest times for the Invisible Empire. Not only were the string of electoral defeats in 1924 amplified by similar losses in 1926, but the scandals that rocked the Klan in the latter half of the 1920s rolled back the remaining momentum of the hooded order. The corruption and immorality that surrounded Klansmen like D.C. Stephenson, Heber Nations, C.C. Crawford, Pierre Wallace, and many others reminded hooded members that the Invisible Empire had grown increasingly political and less moral over the 1920s. This was especially evident in the cases of corruption that far outpaced reform legislation pursued by Klan politicians in states controlled by the Invisible Empire. These scandals would only deepen as the decade wore on, and by 1930, Klan membership had dropped steeply from its previous high watermark of roughly five million to about fifty thousand. ${ }^{141}$

\footnotetext{
${ }^{140}$ Kansas City Call, 24 June 1927.

${ }^{141}$ Chalmers, Hooded Americanism, 100-108, 171-174, 291-318; Blee, Women of the Klan, 21-28, 93-98, 175; Dumenil, The Modern Temper, 235-245.
} 


\section{Chapter 7: "Candidate Hoover and His Buddies"}

As Jefferson City residents prepared to go to the polls on November 6, 1928, they were shocked to learn of a series of fiery crosses burned along Lafayette Street. The hilly road which began at the Missouri State Penitentiary and ended at the "foot" near the allblack Lincoln University was the central avenue for the city's African American population. Quick to tamp down any allegations of involvement, both the local Republican and Democratic parties denounced the incident. ${ }^{1}$ The Jefferson City Daily Capital News followed with an editorial denouncing the Klan's involvement in politics. ${ }^{2}$ A few weeks before the appearance of the burning crosses, the Cole County Lee Democratic Negro Club had formed in an effort to mobilize African Americans into abandoning the Republicans. In a tactic used statewide, local Democrats charged Republicans with refusing to promote the fair treatment of African Americans. While far from calling for racial equality, the message was a critique of the gubernatorial administration of Sam A. Baker, which had seemingly abandoned black voters soon after the 1925 inauguration. ${ }^{3}$ When the crosses burned on Lafayette Street, local Democrats were quick to point out how the incendiary creations could be interpreted as a response to

\footnotetext{
${ }^{1}$ Jefferson City Post-Tribune, 5 November 1928; Jefferson City Daily Capital News, 6 November 1928.

2 Jefferson City Daily Capital News, 4 November 1928, 6 November 1928.

${ }^{3}$ Jefferson City Post-Tribune, 5 November 1928; Jefferson City Daily Capital News, 6 November 1928.
} 
their efforts to court black voters. ${ }^{4}$ The Daily Capital News fanned these flames by alleging that Republicans in Cole County were aligned with the Klan. ${ }^{5}$

For Cole County Republicans, it was an interesting twist to now face allegations of a Klan alliance. Since the hooded order first appeared in the county, Republicans had shied away from its political intentions while Democrats formed close relationships. This is not to say, however, that Republicans did not have their own Klan ties. In fact, former exalted cyclops Heber Nations was one of the most prominent Republicans in the state. Yet, to the charges of Klan allegiance, Cole County Republicans issued a firm response. First, they offered a $\$ 100$ reward for information leading to the arrest of the guilty parties. Second, Postmaster Ben H. Lindhardt claimed that Democrats burned the notorious crosses while also distributing anti-Catholic literature throughout the county in an effort to frame Republicans. Finally, Republicans campaigned hard against Klanaligned Democrats, particularly sheriff L.C. Withaup, who they said were lax in the enforcement of the law. ${ }^{6}$ Ultimately, the true culprit behind the fiery crosses was never identified.

By the latter half of the 1920s, the Democratic Party of Missouri had to make a tough decision about its political future. The party had long been splintered along rural and urban factions on a number of issues, but it tended to unify in major elections. This

\footnotetext{
${ }^{4}$ Jefferson City Post-Tribune, 5 November 1928; Jefferson City Daily Capital News, 6 November 1928.

5 Jefferson City Daily Capital News, 6 November 1928.

${ }^{6}$ Jefferson City Post-Tribune, 17 October 1928, 3 November 1928, 5 November 1928, 6 November 1928; Jefferson City Daily Capital News, 6 November 1928.
} 
had not been the case in 1922 when pro-Woodrow Wilson opponents of James A. Reed tried to undercut his re-election bid for the US Senate. Despite this internal quarrel, Reed managed to rally Democrats to his campaign and easily dispatched with Republican R.R. Brewster. Similarly, a tug-of-war for political control in Kansas City caused a split between the rabbit and goat factions of the city's Democratic political machines in 1924. With Joe Shannon seeking to diminish Tom Pendergast's power in the city by abandoning the party for that year's elections, Republicans achieved substantial success in the metropolitan area, including unseating a young Pendergast veteran named Harry S. Truman in rural Jackson County.

Another key issue from the 1920 s that splintered state Democrats involved African American support within the party. While urban party members, including Tom Pendergast, had appealed to black voters as early as the late $19^{\text {th }}$ century, rural Democrats were less open to African American inclusion. Though the state legislature had repeatedly refused to pass Jim Crow type laws, efforts towards such legislation by rural Democrats kept the issue constantly at the forefront. The Democratic efforts to recruit black voters were hurt by rural appeals to white supremacy, as has been seen in Chapter 4. In addition, the state party had a seemingly close relationship with the Klan in key elections, most notably the 1924 gubernatorial campaign of A.W. Nelson. While far from unified on the question, state Democrats realized by 1925 that Missouri's growing African American population was key to the party's political fortunes.

As such, the state Democratic Party appealed to black voters on three fronts. First, though the party did not hold major power at the state level or in the city of St. Louis, Democrats nevertheless promised African Americans positions of patronage after 
successful electoral victories. The blueprint for such a plan was laid out through the efforts pursued by the Pendergast machine in Kansas City prior to the 1920s. To this end, Democrats also reached out to African Americans by critiquing the failings of Republican state officials. While this proved to be difficult during the administration of Arthur Hyde who was an active member of the National Association for the Advancement of Colored People, his successor, Sam A. Baker, did not have a strong civil rights record. In fact, though he won the governor's seat on a campaign denouncing the Klan, Baker quickly made it clear that he would not pursue notable civil rights or anti-Klan legislation. Additionally, Baker's meddling with the funding and administration of the all-black Lincoln University brought severe retaliation from the African American press.

With Republicans controlling key state positions, including Baker in the governor's mansion, it was easy for Democrats to run as the insurgency seeking to reform government. To this end, the Democrats utilized their last recruitment technique: portraying themselves as anti-Klan. Just as the Republicans had done earlier in the 1920s, the Democrats now accused their political rivals of aligning with the Klan. This proved to be difficult since key state Republicans had already spoken out in opposition to the Klan. Additionally, due in large part to opposition, internal scandals, and political failures, the Klan was a shell of its former self, both locally and nationwide, by the late 1920s. Nevertheless, Democrats accused Republicans, most notably 1928 presidential candidate Herbert Hoover, of kowtowing to the Klan. Following the scandals of Republican Klansmen both in the state and nationwide, this last tactic proved to be extremely successful as the 1920 s wore on and culminated in the 1928 presidential campaign of Democrat, and noted Klan opponent, Al Smith. 
Beginning in 1925, Missouri Democrats targeted African American voters in three key elections. First, the party utilized the negative reputation of Republican Victor Miller, a former city police commissioner, to appeal to African Americans in the St. Louis mayoral election of that year. The Democrats touted the congressional career of its candidate William Igoe while bringing extensive attention to Miller's non-committal stance on the Ku Klux Klan and his poor record on issues important to the African American community. Miller ultimately won the election, but the defection of key African American leaders from the Republican camp, particularly J.E. Mitchell of the St. Louis Argus, greatly aided the Democratic Party.

A year later, in 1926, Democrats saw a strong chance to occupy both of Missouri's US Senate seats. Following the death of Republican Seldon Spencer, George H. Williams, whom Governor Baker appointed to fill Spencer's spot, announced his intention to seek the seat long-term. In addition to backing the strong candidacy of Congressman Harry Hawes, Democrats accused Williams of being closely tied to the Klan. While black voters did not rally to the Democrats like they did in St. Louis in 1925, the specter of the Klan's ties to Williams did push some African Americans into the Democratic camp. In the end, Hawes matched his predecessor, James Reed, and ran surprisingly strong in rural counties while also building an urban ethnic voting bloc. He easily defeated Williams and ushered in a brief period where both of Missouri's Senators were anti-Klan Democrats.

Finally, state Democrats utilized the 1928 presidential election as a way to appeal to black voters at the local, state, and national level. In these campaigns, Democrats consistently painted Republicans as the party of the Klan, including cartoons depicting 
"lily-white" candidates walking arm-in-arm with Klansmen. While such attempts did not override Republican support in the state, the percentage of African Americans voting Democratic was the highest it had ever been in Missouri. Most notably, nearly fifty percent of black voters in Kansas City cast their ballot for Democrats. Ultimately, the gains made by the state Democratic Party in the African American community proved to be only minimally successful during the 1920s. Yet, when compared with the national shift of black voters into the Democratic Party around 1936, it is quite apparent that the efforts of Missouri Democrats preceded national trends. Additionally, the use of the Klan issue as a recruiting tool also proved to be a key tactic that aided this voter realignment.

The first election that showcased the impending shift of African Americans in Missouri towards the Democratic Party occurred in St. Louis in 1925. While St. Louis had been a predominately Republican city, with a member of the party serving as mayor since 1909, Democrats felt they had a good chance in the mayoral campaign with leading candidate William Igoe. A St. Louis native, Igoe had grown up in the city and earned a law degree from Washington University. As well as being a well-known city attorney, Igoe had also served city residents as a member of Board of Aldermen. In 1912, he won a seat in Congress and stayed in the House chamber until 1921. Upon retiring from office, Igoe returned to his St. Louis law practice until he was convinced to run for mayor. ${ }^{7}$ As the headliner of the Democratic ticket, Igoe faced little opposition in the party primary, but a larger feat awaited him against the eventual Republican candidate, Victor Miller.

\footnotetext{
${ }^{7}$ Mitchell, Embattled Democracy, 86; St. Louis Post-Dispatch, 20 April 1953.
} 
A native of Joplin, Missouri, Victor Miller was not new to Missouri politics. Like Igoe, Miller graduated with a law degree from Washington University in St. Louis. He was a practicing attorney in the city for close to a decade before Governor Arthur Hyde appointed him to the police commission in 1921. As a commissioner, Miller guided the police department through a series of scandals involving brutality, racial discrimination, and possible ties to the local Ku Klux Klan. His controversial reputation, combined with disagreements with other members of the board, caused Hyde to remove Miller from the police commission in $1923 .{ }^{8}$ Almost immediately, Miller opened a campaign for governor, but he failed to mobilize much support outside of St. Louis. After failing to secure the Republican Party nomination in the 1924 primary, Miller returned to St. Louis and contemplated a run for mayor. ${ }^{9}$

Throughout his campaign, Miller faced stiff opposition from prominent black Republicans. Most notable was the editorial attacks launched against him by the St. Louis Argus. The Argus' editor, J.E. Mitchell, had long been a Republican supporter, and he showed no signs of abandoning the party. Yet, he could not back Miller. Mitchell's reasoning was simple: when given the opportunity to promote African American rights and silence groups like the Klan, Miller failed. ${ }^{10}$ According to Mitchell, Miller had been petitioned so many times as police commissioner to increase the number of African American law enforcement officers that Governor Hyde had to step in and reprimand

\footnotetext{
${ }^{8}$ St. Louis Post-Dispatch, 13 April 1923, 14 April 1923, 6 January 1955.

${ }^{9}$ St. Louis Post-Dispatch, 6 August 1924, 6 January 1955.

${ }^{10}$ St. Louis Argus, 6 March 1925, 3 April 1925; Mitchell, Embattled Democracy, 86-88.
} 
him. Miller later touted the increase in black officers in his appeal to African American voters, much to the disgust of the Argus. ${ }^{11}$

Additionally, Miller drew the Argus' ire because he never directly severed ties with the Klan. While Miller made it a point on the campaign trail to mention that he never joined the Klan - even going so far as to offer a $\$ 25,000$ reward for anyone who could provide evidence to prove this claim wrong - he never openly denounced the hooded order. ${ }^{12}$

Since J.E. Mitchell was not ready to switch political allegiances, he instead lobbied hard for the election of Republican Louis Aloe. Aloe was a well-respected Jewish businessman in St. Louis who had made a name for himself as the one-time president of the city's board of aldermen. While serving in that post, Aloe had promoted fair government while also striking back against the forces of anti-Semitism, particularly the distribution of Henry Ford's Dearborn Independent and the growth of the local Ku Klux Klan. In the eyes of the Argus, Aloe had also been instrumental in improving the relationship between the white and black community. ${ }^{13}$ While Aloe ran a strong campaign that drew significant African American support, he was unable to top Victor Miller in the primary.

After the respective party primaries, Victor Miller and William Igoe emerged as the leading candidates. Having strongly backed Louis Aloe, J.E. Mitchell was left with a tough decision in the wake of his defeat. On the one hand, Mitchell was not ready to completely back the Democratic Party. Thus loyalty to the Republicans would mean

${ }^{11}$ St. Louis Argus, 27 February 1925.

12 St. Louis Post-Dispatch, 21 March 1925, 24 March 1925, 26 March 1925, 27 March 1925, 4 April 1925, 5 April 1925; St. Louis Argus, 3 April 1925.

13 St. Louis Argus, 20 February 1925, 6 March 1925. 
supporting Miller. Yet, on the other hand, Mitchell did not feel comfortable backing Miller and his possible Klan ties. This quandary was made worse when Louis Aloe alleged that the Klan had played a major role in his loss to Miller in the primary. ${ }^{14}$ Opting to take a middle of the road approach, Mitchell's Argus called out Miller in an editorial that advised readers to forsake party loyalty in favor of candidates that would serve their interests. ${ }^{15}$ Mitchell's intentions were clear: vote Republican, but don't vote for Miller.

The Argus' stunning editorial produced divisions within the African American community. George B. Vashon and his St. Louis Colored Democratic Club utilized the Argus' message to recruit for the Democrats. ${ }^{16}$ Warning voters about the dangers of a Miller victory, Vashon declared that the "election of Mr. Igoe will be the most stunning blow to the Ku Klux Klan that can be delivered, and it will undo the Jim Crow deviltry of the only Jim Crow city administration that has ever disgraced St. Louis."17 The Argus followed Vashon's lead by pointing out how prominent black leaders such as Homer G. Phillips and George L. Vaughn were opposed to Miller. ${ }^{18}$ The Argus also accused Miller of using white men to corral African American support. ${ }^{19}$

${ }^{14}$ St. Louis Star, 14 March 1925; St. Louis Post-Dispatch, 22 March 1925, 23 March 1925.

${ }^{15}$ St. Louis Argus, 20 March 1925.

${ }^{16}$ St. Louis Argus, 27 March 1925.

17 St. Louis Argus, 27 March 1925.

${ }^{18}$ St. Louis Argus, 27 March 1925; St. Louis Post-Dispatch, 4 April 1925; Mitchell, Embattled Democracy, 86-88.

${ }^{19}$ St. Louis Argus, 27 March 1925. 
Attempting to counter efforts by the Democrats to court African Americans, Republicans promoted the efforts of prominent African American leader Jordan Chambers to keep black voters in line with the party. ${ }^{20}$ They also paid for strategic ads to be placed in the Argus promoting Miller's qualifications and comments on the Klan. ${ }^{21}$ A group of African American clergymen were also called upon to write an op-ed in the St. Louis Star in support of Miller. ${ }^{22}$ Finally, Congressman L.C. Dyer, the political hero who authored a failed federal anti-lynching law, crisscrossed the city stumping for Miller. Beloved in his home district, Dyer spoke of Republican efforts to expand rights for African Americans. Dyer also reminded black voters that it was the Democrats who were responsible for disenfranchisement in other parts of the country. ${ }^{23}$ Ultimately, Dyer, along with Louis Aloe, put any differences they had with Miller aside to campaign on behalf of the party. ${ }^{24}$

In addition to utilizing negative perceptions of Miller in the African American press, Democrats also attacked the candidate for his weak stance on several issues. First, Miller was accused of being uncompromising in his stance on prohibition. As a former police commissioner, Miller ran on a law and order platform. Democrats used this position to appeal to German and African American Republicans. For Germans, the Democrats promised "wet" policies that would scale back Prohibition. Hoping the obtain

${ }^{20}$ St. Louis Argus, 27 March 1925; Mitchell, Embattled Democracy, 86-88. Jordan Chambers, though a Republican during the 1920s, has been credited with playing a major role in the realignment of black voters to the Democrats during the 1930s. Lang, Grassroots at the Gateway, 24-25.

${ }^{21}$ St. Louis Argus, 3 April 1925.

22 St. Louis Argus, 10 April 1925.

${ }^{23}$ St. Louis Post-Dispatch, 20 March 1925, 6 April 1925.

${ }^{24}$ St. Louis Post-Dispatch, 20 March 1925, 22 March 1925, 6 April 1925. 
a sizable black vote from African Americans, the Democrats referenced racial confrontations between the black community and Miller's police force.$^{25}$ Democrats also knew that Miller could be attacked for his noncommittal stance on the Klan. While he had already faced charges of Klan ties in his bid for the Republican gubernatorial nomination in 1924, St. Louis Democrats put Miller's feet to the fire with a new round of accusations. $^{26}$

Though he had a less than sterling reputation in the city, Victor Miller won the St. Louis mayor's race over William Igoe by 3000 votes. ${ }^{27}$ Miller managed to keep Republicans strongly in line with his candidacy while also not losing a significant portion of the African American vote. However, while Democrats were not able to topple the entrenched Republicans in St. Louis, they did make inroads in the African American community as roughly $30 \%$ of black voters in the city cast their ballot for Igoe. ${ }^{28}$ The Argus noted this when it declared that "Negroes voted against Mr. Miller as they had never before voted in this city against a man on the Republican ticket." ${ }^{29}$ Yet, despite the potential electoral swing, African Americans, including J.E. Mitchell at the Argus, were not quite ready for realignment. Nevertheless, they realized that the big tent of the GOP now made room for Klansmen. This point was not lost on the Argus when it reported a

${ }^{25}$ Mitchell, Embattled Democracy, 86-88.

${ }^{26}$ Mitchell, Embattled Democracy, 86-88.

27 St. Louis Post-Dispatch, 8 April 1925; St. Louis Argus, 10 April 1925; Mitchell, Embattled Democracy, 86-88.

${ }^{28}$ Mitchell, Embattled Democracy, 86-88; Grothaus, "Kansas City Blacks, Harry Truman, and the Pendergast Machine," 73.

${ }^{29}$ St. Louis Argus, 10 April 1925. 
fiery cross lit in front of St. Louis city hall allegedly celebrating Miller's mayoral victory. ${ }^{30}$

Though Democrats failed to garner substantial African American support in the 1925 St. Louis mayoral campaign, the party was not deterred in efforts to continue this push in 1926. While not a major election year, 1926 did hold the promise of the impending senatorial election to fill the seat left vacant by Seldon Spencer who passed away in 1925. ${ }^{31}$ Upon learning of Spencer's death, Governor Sam Baker scoured the state looking for an adequate Republican replacement that would not only fill the seat, but had a good chance of winning election in 1926. The obvious favorite was Arthur Hyde who had been Baker's predecessor in the governor's mansion and still held considerable sway within the state Republican Party. Baker had other plans, however, and selected George H. Williams. ${ }^{32}$

An attorney from St. Louis, Williams initially planned to only serve out the remainder of Spencer's term. ${ }^{33}$ Despite his decision to only serve temporarily, the St. Louis Post-Dispatch supported Baker's appointment of Williams and editorialized that the governor "exercised good judgment" with the selection. ${ }^{34}$ Considering the circumstances, Baker was no doubt happy to appoint a Republican to Congress as

\footnotetext{
${ }^{30}$ St. Louis Argus, 10 April 1925.

${ }^{31}$ St. Louis Post-Dispatch, 17 May 1925, 19 May 1925, 20 May 1925, 22 May 1925, 25 May 1925; Kansas City Star, 25 May 1925, 29 May 1925.

32 St. Louis Post-Dispatch, 17 May 1925, 19 May 1925, 20 May 1925, 22 May 1925, 25 May 1925; Kansas City Star, 25 May 1925, 29 May 1925.

${ }^{33}$ St. Louis Post-Dispatch, 17 May 1925, 19 May 1925, 20 May 1925, 22 May 1925, 25 May 1925; Kansas City Star, 25 May 1925, 29 May 1925.

${ }^{34}$ St. Louis Post-Dispatch, 26 May 1925.
} 
Williams was only the third Missouri member of the party to serve in the Senate since the end of Reconstruction. ${ }^{35}$ While Republicans had struggled to gain a spot in the Senate, Williams, a graduate of both Princeton University and Washington University, made a name for himself largely outside of major party politics as a well-known St. Louis attorney and later circuit court judge. ${ }^{36}$ By the 1920 s, though, Williams emerged as a state party leader and played a key role in approving party planks during the 1924 Republican state convention.

While his Senate appointment in 1925 garnered the support of the governor, the party, and members of the press, several state Republicans felt that Williams was only filling the seat until a more serviceable candidate would emerge in time for the 1926 election. ${ }^{37}$ In their minds, a successful politician was needed to continue the Republican surge within the state during the 1920s. If Williams was going to hold onto his Senate seat through 1926, he was going to have to defeat not only Arthur Hyde who was seeking redemption after a failed bid to be selected as Calvin Coolidge's running mate in 1924, but also the likely Democratic challenger, Harry Hawes. Despite the opposition, Williams eventually announced his intention to run for the long term Senate seat. ${ }^{38}$ After a grueling campaign against several Republican challengers, Williams won the party's primary in August $1926 .{ }^{39}$

${ }^{35}$ St. Louis Post-Dispatch, 25 May 1925.

${ }^{36}$ St. Louis Post-Dispatch, 25 May 1925; Kansas City Star, 25 May 1925, 29 May 1925.

37 St. Louis Post-Dispatch, 19 May 1925, 20 May 1925, 22 May 1925, 25 May 1925; Kansas City Star, 25 May 1925, 29 May 1925.

${ }^{38}$ St. Louis Post-Dispatch, 25 May 1925, 12 July 1925; Kansas City Star, 25 May 1925, 29 May 1925.

${ }^{39}$ Mitchell, Embattled Democracy, 92-93; St. Louis Post-Dispatch, 4 August 1926, 5 August 1926. 
With Williams emerging as the favorite on the Republican side after Hyde opted not to seek the Senate seat, attention to turned to Harry Hawes and the Democrats. Though far from a household name to the average voter outside of St. Louis, Hawes nevertheless launched an ambitious campaign for Senate based around his political legacy. It had been Hawes who helped launch the gubernatorial career of Joseph Folk in 1904 as a member of St. Louis' Jefferson Club. ${ }^{40}$ Likewise, Hawes' time in the state legislature was marked by a series of bipartisan successes, including a program to modernize Missouri's roadway system through the State Highway Act of $1917 .{ }^{41} \mathrm{He}$ also successfully sidestepped the friction between the pro-Woodrow Wilson and pro-James Reed factions of the state Democratic Party in the early 1920s by taking a middle of the road stance that appealed to both sides and alienated neither group. ${ }^{42}$

While opting to take a non-committal stance on issues like the League of Nations, World Court, and Prohibition, Hawes did build an urban ethnic voting base in St. Louis that elected him to Congress in 1920, 1922, and 1924. Similar to fellow Democrat James Reed, Hawes rallied his urban base through his appeal to the needs of the city as well as his opposition to the Klan. ${ }^{43}$ Hawes' appeal to both of these concerns also won him crossstate support from the Pendergast and Shannon machines of Kansas City, who had recently reunited following a disastrous split in $1924 .{ }^{44}$ With the Democratic bases of

\footnotetext{
40 Mitchell, Embattled Democracy, 84.

${ }^{41}$ Mitchell, Embattled Democracy, 84.

42 Mitchell, Embattled Democracy, 84.

${ }^{43}$ Mitchell, Embattled Democracy, 84-85.

${ }^{44}$ Mitchell, Embattled Democracy, 85-86.
} 
both of Missouri's major metropolises behind him, Hawes turned to the out-state counties seeking to appeal to enough rural support to ensure victory on Election Day.

Though his middle of the road stance on key issues appeased warring Democrats in both the cities and the farm country, Hawes' sudden, outward opposition to prohibition and the World Court in the summer of 1926 threatened to splinter dry Democrats who backed Charles M. Hay. As one of the state's most prominent drys, Hay was supposed to be the Democrat's trump card for rural voters who favored prohibition. While he initially played along in his role, Hay began to split from Hawes and considered a last minute run for Senate when the candidate appeared to back "wet" interests. ${ }^{45}$ After momentum for this plan failed to materialize, Hay opted instead to call upon the less appealing of the other dry Democratic candidates, Ewing Cockrell and Willis Meredith, to drop out before the August primary to guarantee that dry Democrats could rally to one candidate in opposition to Hawes. When neither man dropped out, WCTU state president Nellie Burger proposed a compromise where Meredith would run against Hawes in the short term race, while Cockrell opposed Hawes in the long term. ${ }^{46}$ Despite efforts to rally dry Democrats, Hay and Burger's plan failed and Hawes easily won the primary. ${ }^{47}$ After putting aside their differences, Hay, Cockrell, and Meredith eventually fell back in party line and became key dry voices for the Democrats in rural Missouri. ${ }^{48}$

\footnotetext{
${ }^{45}$ Mitchell, Embattled Democracy, 88-91.

${ }^{46}$ Mitchell, Embattled Democracy, 90-92; St. Louis Post-Dispatch, 11 January 1926, 9 June 1926, 23 June 1926, 2 July 1926, 17 July 1926, 31 July 1926; St. Louis Star, 2 July 1926, 17 July 1926.

${ }^{47}$ Mitchell, Embattled Democracy, 93; St. Louis Post-Dispatch, 4 August 1926, 5 August 1926.

${ }^{48}$ Mitchell, Embattled Democracy, 96.
} 
Considering that George H. Williams had been involved in the Republican's antiKlan state party plank in 1924, and his chief rival, Harry Hawes, was a prominent opponent of the Klan, the St. Louis Post-Dispatch gleefully looked forward to the "pleasing novelty to have a state-wide campaign in Missouri on Democratic and Republican lines, without the injection of misleading manoeuvers touching Ku Kluxism and prohibition." ${ }^{\circ 9}$ The Post-Dispatch was being naïve. While none of the anticipated candidates had significant Klan ties, the Invisible Empire, as it had done in so many other states, would find a politician to get behind. Even if the candidate did not accept the hooded order's support, the Klan issue emerged in the 1926 election just as it was in 1924. Yet, the election year of 1926 did not hold the same promise for the Klan as those held in previous years. Though some in the organization still sought to flex the organization's muscles, the Missouri Klan made a decided move away from more overt political activism as the decade wore on. In part, this was tied to the scandals surrounding D.C. Stephenson and other Klansmen, but in many ways, the order realized that its not-so-secret political activities in previous years had done more harm than good. Grand Dragon William Campbell indicated as much when he told fellow members that "it would be unwise for Missouri Klansmen to make any concerted bid for activity in the primary." ${ }^{50}$ Nevertheless, the Klan knew that to counter claims that it was deteriorating in Missouri, it needed to make a strong showing statewide.

In July 1926, several Missouri newspapers reported that William Campbell gave endorsements to George H. Williams as well as Democratic Senate candidate Willis H.

\footnotetext{
${ }^{49}$ St. Louis Post-Dispatch, 8 November 1925.

${ }^{50}$ Missouri Valley Independent, 22 July 1926.
} 
Meredith. ${ }^{51}$ Upon discovering his name connected to the Klan, Williams publicly disputed whether the organization had actually endorsed him since the initial meeting where his name was allegedly discussed had been secret. ${ }^{52}$ Nevertheless, the specter of Klan support haunted him. The St. Louis Post-Dispatch commented that while Williams may not have sought the organization's support, he had not yet repudiated it which would be the "courageous, sincere and manly thing to do." 53 Not ready to admit that its "novelty" comment about the campaign from a few months prior had been shortsighted, the Post-Dispatch devoted extensive coverage to the Klan issue in relation to Williams and concluded that "the Ku Klux Klan has injected itself into the fight, threatening to undo what has been accomplished for the Senator and generally upsetting the campaign plans for the final week [before the primary]." ${ }^{, 54}$

Williams did not have to fight allegations of Klan ties as intensely as prior candidates, but he did have some uncomfortable moments when it came to the Invisible Empire. First, though he handily won his primary against David M. Proctor of Kansas City in August, Williams' victory was sullied by the allegations of the Klan's endorsement a few weeks prior. ${ }^{55}$ William Campbell disputed this alleged endorsement, but it was noted in the press that the Grand Dragon tended to speak favorable of the

${ }^{51}$ St. Louis Post-Dispatch, 24 July 1926; Kansas City Star, 23 July 1926, 24 July 1926, 25 July 1926; St. Louis Argus, 30 July 1926. In explaining his decision to back Meredith, Campbell said that the candidate "is a high type man with a good reputation and could be expected to stand for law enforcement."

52 St. Louis Post-Dispatch, 24 July 1926; St. Louis Star, 24 July 1926.

53 St. Louis Post-Dispatch, 26 July 1926.

${ }^{54}$ St. Louis Post-Dispatch, 25 July 1926.

55 St. Louis Post-Dispatch, 24 July 1926; Kansas City Star, 23 July 1926, 24 July 1926, 25 July 1926; St. Louis Argus, 30 July 1926. 
incumbent senator while disparaging both Hawes and Proctor. To Campbell, Hawes was not the ideal candidate because he was "rapidly opposed to our organization." As for Proctor, Campbell's denunciation of the politician led to continuing problems for Williams as he had to endure questions involving a growing feud between Proctor and Campbell. ${ }^{56}$

The ill will between the two men centered on an address given by Campbell at a Klan event in the southwest Missouri town of Anderson in September 1926. During his speech, Campbell reiterated his earlier opinion that Proctor was really a "wet" candidate masquerading as a "dry."57 Though this statement occurred well after the August primary, Proctor told the press that Campbell's previous comments about the candidate as well as his influence within the Klan had swayed the primary in Williams' favor. In the wake of the Anderson speech, Proctor announced his intention to sue Campbell for attacking his character and reputation. While Campbell brushed off Proctor's possible litigation as a mere "political gesture," Williams was forced to again deny any ties between himself and the Klan. ${ }^{58}$

With only a few weeks remaining before the election, Williams hoped that voters would forget all connections between himself and the Klan, particularly any meetings with Grand Dragon William Campbell. ${ }^{59}$ This sentiment was greatly aided by the

${ }^{56}$ St. Louis Post-Dispatch, 24 July 1926; Kansas City Star, 23 July 1926, 24 July 1926, 25 July 1926; St. Louis Argus, 30 July 1926; Missouri Valley Independent, 5 August 1926.

57 Joplin Globe, 24 September 1926, 22 October 1926, 23 October 1926; Kansas City Star, 23 July 1926; Missouri Valley Independent, 5 August 1926, 30 September 1926, .

${ }^{58}$ St. Louis Post-Dispatch, 22 October 1926; Joplin Globe, 22 October 1926, 23 October 1926.

${ }^{59}$ Despite denying any connection to the Klan, Williams admitted in October 1926 that he met Grand Dragon William Campbell during a train ride from St. Joseph to St. Louis. However, Williams 
decision of the Prosecuting Attorney of McDonald County not to pursue Proctor's libel charge against Campbell. ${ }^{60}$ But when Williams' name emerged alongside that of Vivian Tracy Wheatcraft during the Reed hearings, the Klan issue was raised once more. Though James Reed was unable to quiz Wheatcraft about her political activities and rumored poison squads in Indiana and Missouri, records indicate that Wheatcraft and Williams were quite familiar with one another. Several newspapers noted that Wheatcraft had taken up temporary residence in Princeton, Missouri, while working for the Williams campaign, and the St. Louis Star reported that both had served as speakers at a rally in Gallatin. ${ }^{61}$

Despite the dubious connections between Williams and Wheatcraft, that controversy did not become as central to the campaign as the Klan affidavits directed at A.W. Nelson in 1924. Instead, the race was marked by continued efforts by Democrats to recruit African American voters to the party. As with the 1925 St. Louis mayoral campaign, Hawes and the Democrats made inroads in the black community in an effort to win over African American voters. ${ }^{62}$ While Republicans carried most of the black vote in the cotton belt, Kansas City African Americans nearly split among the parties with an estimated $42 \%$ casting votes for Democrats. ${ }^{63}$ Additionally, though the Argus reversed its earlier course from the mayoral campaign and endorsed Williams, St. Louis Democrats

alleged that he thought the man he met was a Methodist minister, and did not know it was Campbell until later. St. Louis Post-Dispatch, 21 October 1926, 22 October 1926.

${ }^{60}$ Joplin Globe, 22 October 1926, 23 October 1926.

${ }^{61}$ St. Louis Post-Dispatch, 23 October 1926; Springfield Republican, 22 October 1926; Joplin Globe, 22 October 1926; St. Louis Star, 22 October 1926.

${ }^{62}$ Mitchell, Embattled Democracy, 96-98.

${ }^{63}$ Mitchell, Embattled Democracy, 101. 
certainly collected increased black voting totals with George B. Vashon challenging the incumbent Leonidas Dyer in the 12th Congressional District. ${ }^{64}$

Though the candidates provided oratory fireworks in the final days of the campaign, including utilizing James Reed and Arthur Hyde as frequent keynote speakers, Hawes quietly and successfully mobilized a diverse coalition composed primarily of "wet" and anti-Klan voters to carry him to victory on Election Day. ${ }^{65}$ He even withstood a last minute accusation about his wife's ties to Catholicism, a blatant attempt to stir up anti-Catholic sentiments among voters. ${ }^{66}$ With Hawes joining Reed in Washington D.C., Missouri now claimed two anti-Klan senators. Hawes' victory was also significant because he continued the growing alliance between the state Democratic Party and African American voters. He may not have yet convinced a majority of African Americans to back the party, but his victory, backed by an increasing black vote, served as a crushing blow for the Missouri Klan's political ambitions.

James Reed was no doubt happy to see a fellow member of the Democratic Party in the Senate chamber. Yet, Reed's time in Washington D.C. was almost over. In the heart of the 1926 campaign, Reed surprised many of his supporters by announcing his decision not to seek re-election. ${ }^{67}$ While some supporters assumed that the senator planned to return home to Missouri, Reed's movements after his announcement showed

\footnotetext{
${ }^{64}$ Mitchell, Embattled Democracy, 99-101.

65 Mitchell, Embattled Democracy, 96-100; Kansas City Star, 24 October 1926; Weekly Kansas City Star, 27 October 1926; St. Louis Post-Dispatch, 24 October 1926, 27 October 1926, 28 October 1926, 29

${ }^{66}$ Weekly Kansas City Star, 20 October 1926.

${ }^{67}$ Mitchell, Embattled Democracy, 104-108.
} October 1926, 3 November 1926. 
his intentions to seek the presidency. Despite Republican dominance of the White House during the 1920s, the path to the Democratic nomination was not an easy one for Reed. ${ }^{68}$ First, his prior verbal jabs at Woodrow Wilson continued to bring him stiff opposition from supporters of the now deceased president. Second, his fiery rhetoric alienated some rural Democrats, particularly drys. Finally, Reed's ascendancy to the nomination was blocked by the groundswell of support for New York governor Al Smith.

Hoping to muddy the waters to force a compromise nomination at the Democratic National Convention, Reed toned down his fiery rhetoric and took more moderate stances on key issues. When he toured the country in 1927 and 1928, Reed advocated for limited government, states' rights, rural infrastructure programs, and an end to political corruption. This last message was aimed directly at the prominent Republican scandals of the decade. ${ }^{69}$ At the Democratic National Convention, Al Smith quickly emerged as the perennial favorite, but he failed to garner enough votes to secure the nomination. Reed saw his chance. On convention floor, Reed supporters began to tout the senator's career, including his sentiments in favor of upholding the 18th Amendment. Reed's doubters could have easily pointed out his noted wet stance in prior campaigns, but the senator moved to silence these objections by circulating correspondence between him and Missouri WCTU president Nellie Burger. It proved to be a sly move by Reed to draw in dry endorsement to offset Smith's overwhelming wet support, but the tactic failed. Eventually, Al Smith won the party's nomination. ${ }^{70}$ When allegedly offered the

\footnotetext{
${ }^{68}$ Mitchell, Embattled Democracy, 106-108.

${ }^{69}$ Mitchell, Embattled Democracy, 107-108.

${ }^{70}$ Mitchell, Embattled Democracy, 107-108.
} 
possibility to serve as Smith's running mate, Reed turned it down. While he campaigned hard for Smith's election in 1928, Reed privately confided to friends that the candidate had little chance of winning because of his Catholicism. ${ }^{71}$

With Reed failing to garner the nomination and opting not to seek re-election, his senate seat was open in 1928. Charles Hay quickly emerged as the odds on favorite to capture Reed's spot, but the retiring senator actively spoke out against his former rival. He even went so far as to accuse Hay of being friendly with the Klan. ${ }^{72}$ Such an accusation gained later traction when Hay appeared at Heber Nations' graft trial in 1930 to defend the former Klansman's character. Despite Reed mounting opposition to his campaign, Hay easily won the Democratic primary. ${ }^{73}$ As Al Smith and Charles Hay took to the campaign trail, the St. Louis Post-Dispatch pondered how a potential shift of African American voters to the Democratic Party would impact local Republicans. When posed the question, St. Louis Republicans scoffed at the suggestion and pointed out that six of the fifty-six members of the Republican City Committee were African Americans. Yet, despite this initial confidence, there were notable shifts among African Americans in the city. Building upon his efforts in 1925 and 1926, George B. Vashon continued to organize local blacks through his Association of Negro Democratic Clubs which claimed to have several thousand members. ${ }^{74}$

\footnotetext{
${ }^{71}$ Mitchell, Embattled Democracy, 107-108.

72 Mitchell, Embattled Democracy, 109-110.

${ }^{73}$ Mitchell, Embattled Democracy, 111.

${ }^{74}$ St. Louis Post-Dispatch, 30 September 1928.
} 
In addition to Vashon's work in St. Louis, Dr. William J. Thompkins of Kansas City was active statewide in mobilizing black voters to join the Democratic Party. Originally from Jefferson City, Thompkins grew up in the shadow of the state capitol building. After completing his medical training in Colorado and Washington D.C., he returned to Missouri and set up his first practice in Kansas City. Objecting to the expectation that blacks vote for the party of Lincoln as a sign of loyalty, Thompkins rallied local African Americans to the Democratic Party. Not long after arriving in Kansas City, Thompkins was appointed as the first black superintendent of Kansas City's African American medical facility known as General Hospital No. 2 by Democratic mayor Henry Jost. Active in Kansas City politics, particularly within the Pendergast machine, Thompkins went on to serve as editor of the Kansas City American, a direct rival to the Call, and confidently told all who would listen that $65 \%$ of the state's African American voters would cast ballots for the Democrats in November $1928 .^{75}$

While Thompkins' claims were still a few years away from being fully realized, he was correct that more and more black voters favored the Democrats. For Thompkins, the reasons for the shift were simple. First, as predicted, the mayoral administration of Victor Miller had done little to improve African American conditions in St. Louis and the local police board was considered very anti-black. Second, in the eyes of many African Americans statewide, Governor Sam Baker had ruined Lincoln University through his

\footnotetext{
${ }^{75}$ Gary Kremer, "William J. Thompkins: African American Physician, Politician, and Publisher," Missouri Historical Review 101, no. 3 (April 2007), 168-173; Jeffrey L. Pasley, "Harbinger of the New Deal Coalition: The Pendergast Machine and the Liberal Transformation of the Democratic Party," The Kansas City Public Library, 15 March 2018, http://pendergastkc.org/article/harbinger-new-deal-coalitionpendergast-machine-and-liberal-transformation-democratic-party; St. Louis Post-Dispatch, 30 September 1928.
} 
political meddling in campus affairs. Third, Baker and Miller had both failed to uphold their campaign promises of increased patronage to African Americans. Finally, the $\mathrm{Ku}$ Klux Klan, and other anti-black organizations, found a willing ally in lily-white state Republicans. $^{76}$

Another Pendergast lieutenant who was extremely important in shifting black votes from Republicans to Democrats was Casimir Welch. Before he served under Pendergast, Welch made a name for himself due to his physical prowess. His fighting skills and intimidating demeanor drew the attention of Joe Shannon who enlisted Welch as a political organizer. Under Shannon's direction, Welch rallied African American voters in Kansas City's Sixth District to the Democratic Party by any means necessary. He even achieved his own political success by winning several terms as a municipal judge, though rumors circulated that voter fraud played a significant role in his victories. Despite Welch's early allegiance to Joe Shannon, he would not stay in the "rabbit" camp forever. When Shannon backed Republicans in 1924, and developed a questionable alliance with the Klan, Welch joined the Pendergast machine. In a short period of time, Welch convinced Kansas City black voters, especially those in "Little Tammany," to vote Democratic and vote Pendergast. ${ }^{77}$

Efforts by Kansas City Democrats like Thompkins and Welch to gain a foothold in the African American community met with initial opposition from the Kansas City Call. Headed by C.A. Franklin, an avid Republican, the Call opposed Democratic efforts

\footnotetext{
${ }^{76}$ St. Louis Post-Dispatch, 30 September 1928.

77 Wilson, "Chester A. Franklin and Harry S. Truman," 53-54; Lawrence H. Larsen and Nancy J. Hulston, Pendergast! (Columbia: University of Missouri Press, 1997), 104-105; Schirmer, A City Divided, 153; Pasley, "Harbinger of the New Deal Coalition."
} 
to recruit African Americans, including expanded patronage opportunities and the construction of several notable projects in the black community. ${ }^{78}$ Franklin also overlooked rumors that local Republicans had built an alliance with the Klan in Jackson County, though he refused to endorse the 1924 Republican candidate for governor in Kansas, Ben Paulen, due to his alleged ties to the Klan. ${ }^{79}$ Franklin wavered in his support for some Republicans, but he did not abandon the party. By the end of the decade, however, he began to express further doubts about the trajectory of the Republican Party. The cause for this re-evaluation was the 1928 Republican National Convention in Kansas City. When party officials opted to segregate delegates by race, Franklin unleashed his outrage in the pages of the Call. His commentary on "lily-whitism" did not sway Republicans, and after the convention ended without a major platform addressing civil rights, Franklin expressed doubts about the direction of the party. ${ }^{80}$ Despite his concerns about the Republicans in the wake of the national convention, Franklin nevertheless endorsed Herbert Hoover for president. ${ }^{81}$

Yet, while Franklin may have toed the line when it came to national politics, he surprised many fellow Missourians when he backed Democrat Francis Wilson for governor over Republican Henry Caulfield. ${ }^{82}$ In fact, historian Thomas D. Wilson notes that by the late 1920s the Call no longer advised its readers to vote the straight

${ }^{78}$ Wilson, "Chester A. Franklin and Harry S. Truman," 54.

${ }^{79}$ Wilson, "Chester A. Franklin and Harry S. Truman," 54; Schirmer, A City Divided, 157-158.

${ }^{80}$ Wilson, "Chester A. Franklin and Harry S. Truman," 55; Schirmer, A City Divided, 156; Pasley, "Harbinger of the New Deal Coalition."

${ }^{81}$ Wilson, "Chester A. Franklin and Harry S. Truman," 56.

82 Wilson, "Chester A. Franklin and Harry S. Truman," 56. 
Republican ticket. ${ }^{83}$ "Negro voters should vote for the party that promises best, and most looks like it will carry out its promises," the Call reminded readers in September $1928 .{ }^{84}$ State and local Democrats, while never gaining the full backing of Franklin and the Call, received increasingly positive endorsements from the newspaper: "When the democrats of Missouri, through their platform makers, promised to help [African Americans] get education and employment, they then and there broke party precedent, and put the standard of equality before the law where all could see it." 85 Though he despised the Pendergast machine, Franklin could no longer overlook the efforts made by local Democrats to appeal to black voters. He soon developed a friendly relationship with Harry Truman as the young judge actively worked within the Pendergast machine to increase accessibility to jobs and institutions for African Americans. The two men corresponded regularly in the 1930s, but Franklin never abandoned the Republican Party. ${ }^{86}$

While C.A. Franklin remained a Republican, he nevertheless allowed the pages of the Call to be open to political advertisements from both parties. In an effort to dissuade African Americans from switching parties, Republicans tended to focus on the "myth" of black voter abandonment. "Negroes will never in any large numbers vote to put a Democrat at the head of this country," a Republican advertisement confidently proclaimed in the pages of the Call. Republicans were also quick to remind readers of

\footnotetext{
${ }^{83}$ Wilson, “Chester A. Franklin and Harry S. Truman," 57-75.

${ }^{84}$ Kansas City Call, 7 September 1928.

${ }^{85}$ Kansas City Call, 12 October 1928.

${ }^{86}$ Wilson, "Chester A. Franklin and Harry S. Truman," 57-75.
} 
the Call that the Democratic Party controlled the South in the midst of Jim Crow. As such, Republican ads noted, the Democrats had a history of lynching. Finally, Republicans touted the campaigns of prominent politicians, including Herbert Hoover, Henry Caulfield, and L. Amasa Knox, an African American candidate for the Missouri General Assembly. ${ }^{87}$

To counter Republican attacks, state Democrats promoted the party's work in the black community. William Thompkins' recruitment throughout the state drew notable attention, as did George B. Vashon's political activism in St. Louis. Democrats were also quick to point out how the failings of Republicans in the state influenced realignment. Not only had the Baker administration failed to promote civil rights statewide and autonomy for Lincoln University, but the Republican controlled police board in St. Louis was accused of brutality in several instances, including in the aftermath of a tornado that struck the city in $1927 .{ }^{88}$ In addition to utilizing the pages of the Call to attack Republicans, Kansas City Democrats associated with the Pendergast machine also created their own newspaper to appeal to black voters. Called the American, the new weekly publication was printed in a similar format as the rival Call, but it openly touted Democratic politics. ${ }^{89}$ Yet, more than anything else, men like William Thompkins and George B. Vashon were quick to point out that African Americans were fleeing to the Democratic Party because of "the activity of the Ku Klux Klan for the Republican party

${ }^{87}$ Kansas City Call, 12 October 1928, 19 October 1928, 26 October 1928, 2 November 1928.

${ }^{88}$ Kansas City Call, 26 October 1928, 2 November 1928.

${ }^{89}$ Pasley, "Harbinger of the New Deal Coalition." 
and its candidates." 90 In the midst of the campaign, Thompkins told the press that "when the Republican party welcomes the Ku Klux Klan, it's time [for African Americans] to leave, just as a man runs from a room when a mad dog enters." 91

In an effort to tie Republicans, particularly Hebert Hoover, to the Klan, Democrats launched perhaps their more audacious political advertisement only days before the General Election. Under a bold headline proclaiming "Threat to Negro in $\mathrm{Ku}$ Klux Klan Alliance With Republican Party," the ad laid out the various ways that “Awakened Negro Voters [were] Turning to [the] Democratic Party." The text touting Democratic advances in the black community wrapped around a large cartoon depicting Herbert Hoover alongside two advice wielding Klansmen who remind the candidate to keep his lily-white stance while an African American man representing "15 Million Negroes" stands in the foreground. Underneath the image, the advertisement laid the Klan issue bare:

The Ku Klux Klan is working hand in hand with the Republican National Committee to elect Herbert Hoover president of the United States. The Klan again is riding in America and Hoover and [Vice Presidential candidate Charles] Curtis are it's standard bearers. The hooded hordes called to arms from the remotest corners of this land are mobilized to elect the Republican candidates November $6^{\text {th }}$. The state and county Republican organizations are depending upon this same cowardly outfit to elect their tickets. Make no mistake about this. What price has Klan exacted of the Republican party for it's support? How safe will the Negro be in the event of a Republican victory with his avowed enemy the Ku Klux Klan firmly entrenched in Washington? Why is Candidate Hoover so silent about the Klan? Alfred E. Smith, Democratic candidate for president, has repeatedly denounced this un-American

\footnotetext{
${ }^{90}$ Kansas City Call, 26 October 1928.

${ }^{91}$ St. Louis Post-Dispatch, 30 September 1928.
} 
organization. His election will forever end this menace to the well being of Negroes. A vote for Hoover is a vote for the Klan and Lily Whites, a vote for Smith is a vote for Fair Play and Equal Opportunity. ${ }^{92}$

The assertion that African Americans needed to abandon the lily-whitism of the Republican Party in favor of a "new" Democratic Party was also greatly aided by the campaign of Joseph L. McLemore which was perhaps the biggest gamble the Democrats took in their efforts to appeal to black voters in St. Louis. The goal was to line up a strong African American candidate against Congressman L.C. Dyer, who was well known at the time for his fervent support for a federal anti-lynching bill and had deep roots in St. Louis. With the exception of a short term congressional election defeat in 1914, Dyer had sat in Congress for nearly fifteen years by the mid-1920s. He was beloved in the city's African American community, and was a noted proponent of civil rights and anti-Klan support. Yet, Dyer was not infallible. Throughout his career, he garnered praise and condemnation from constituents, but as the decade wore on, he received more and more critiques from the Argus. ${ }^{93}$ Not surprisingly, Democrats saw their chance and mobilized against Dyer in 1926 and 1928. Efforts to unseat Dyer in 1926 were unsuccessful even though prominent black leaders like Homer G. Philips, George L. Vaughn, and George B. Vashon ran against him.

Returning once more in 1928, Democrats made an even greater effort to remove Dyer from office. This time, party officials in St. Louis gave unwavering support to Joseph L. McLemore. With McLemore serving as a viable candidate in the eyes of many

\footnotetext{
92 Kansas City Call, 2 November 1928.

93 Mitchell, Embattled Democracy, 119-121.
} 
African Americans, a dilemma soon gripped the black community. Would voters continue to support Dyer because of his past civil rights record? Or, would they back McLemore in an effort to finally have an African American from Missouri hold a seat in Congress? The tension of party versus racial loyalty was not lost on the Argus. In fact, the newspaper itself opted not to back either candidate. ${ }^{94}$ Though Dyer eventually won re-election once more, the Democrats could still celebrate the fact that African Americans gave considerable backing to a candidate like Joseph McLemore.

When the dust settled after the 1928 election, Republicans still laid claim to the White House, governor's mansion, and a majority of Missouri's African American voters. ${ }^{95}$ When the 1929 session of the Missouri General Assembly opened in Jefferson City, all three black state representatives were Republicans. ${ }^{96}$ With James Reed opting to retire, Republicans even captured his old Senate seat with Roscoe C. Patterson's victory. ${ }^{97}$ It seemed, at the time, that Republicans had withstood repeated attempts by Democrats to flip black votes. Yet, realignment was on the horizon. For the first time since 1888, Democrats carried St. Louis in the general election. ${ }^{98}$ Added to this, it was estimated that close to half of Kansas City's black voters backed Democratic candidates in 1928. ${ }^{99}$ Though their brethren in southeast Missouri were not yet ready to defect from the Republicans, black voters in that region seriously weighed their options within the

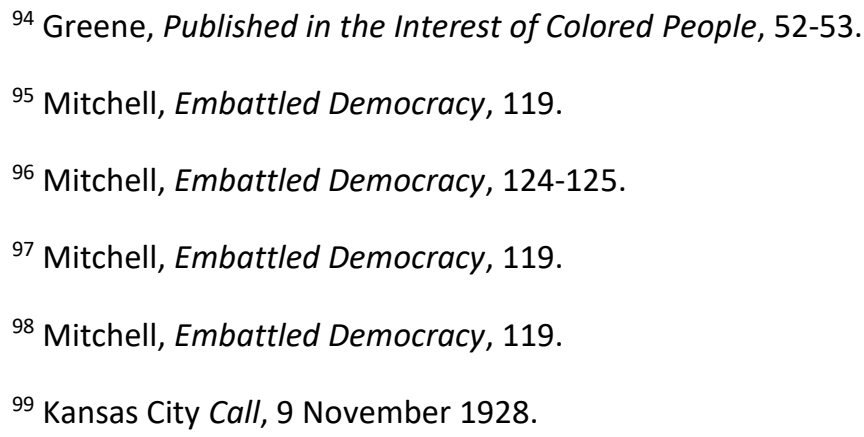


Democratic Party. When Franklin Roosevelt won the presidency in 1932, he ran up strong numbers in the Bootheel, though African Americans still overwhelmingly favored the Republican ticket. Historian Jarod Roll argues that cotton belt blacks did not transition to the Democrats right away because Roosevelt's policies had a greater impact on land owners than tenants. Likewise, Herbert Hoover's cabinet included former governor Arthur Hyde as Secretary of Agriculture who was popular among the state's African Americans, even nearly a decade after leaving office. ${ }^{100}$

Yet, the failure of state Republicans to re-establish strong relationships with the black community came to a head by the early 1930s. Though Governor Henry S. Caulfield was well respected among African Americans for expanded opportunities for blacks and notable opposition to the Klan, his attempts to win back key voters by working against Democrats proved to be a mistake. Following the 1931 lynching of Raymond Gunn in Maryville, legislators from both parties pushed for a state antilynching law. When the Democrats' version passed the legislature, Caulfield vetoed it. Caulfield denied it was a partisan decision citing that the bill was too lenient towards law enforcement officials who failed to stop the lynching. Nevertheless, state Democrats had a field day with Caulfield's veto and the African American press fumed at the decision. ${ }^{101}$ State Republicans also felt the heat over Herbert Hoover's nomination of North Carolina's Judge John J. Parker to the United States Supreme Court. Parker drew heavy opposition from African Americans for his comments against black voting rights. Parker ultimately failed in the Senate to be seated on the Supreme Court, but black Missourians

\footnotetext{
${ }^{100}$ Roll, Spirit of Rebellion, 76-83.

101 Mitchell, Embattled Democracy, 126-135.
} 
took note that Republican Roscoe Patterson voted in favor, while Democrat Harry Hawes voted against the judge. ${ }^{102}$

By the start of the 1930s, Missouri was a very different state politically than it had been at the close of World War I. While state Democrats had not had overwhelming success in convincing African Americans to vote against the Republican Party during the 1920s, the continual shift in voter allegiance is noteworthy. In 1930, it is estimated that roughly seventy percent of black voters in Kansas City backed Democratic candidates. By the election of Franklin Delano Roosevelt in 1932, a majority of African Americans in the state voted for Democrats. ${ }^{103}$ Historian Franklin Mitchell argues that this switch can be attributed to patronage possibilities more than race loyalty. ${ }^{104}$ However, it cannot be overlooked how important the use of the Klan issue was for state Democrats. Little by little, Democratic strategists touted the role of African Americans within the party while also warning about the growing lily-white sentiments of Republicans, both nationally and locally. The Democratic Party was far from immune to its own history of racial hostility, but officials offered hope for interracial cooperation that would benefit blacks and whites. The resistance of men like J.E. Mitchell and Chester Franklin to switch parties based on promises reveals the significance that African Americans placed in past political policy. Yet, despite this hesitation that lasted the entire decade, the political realignment of

\footnotetext{
102 Mitchell, Embattled Democracy, 127-128.

103 Mitchell, Embattled Democracy, 124-131; Kremer, "William J. Thompkins," 173-178; Greene, Kremer, and Holland, Missouri's Black Heritage, 150-151; Schirmer, A City Divided, 153-154; Grothaus, "Kansas City Blacks, Harry Truman, and the Pendergast Machine," 73-82; Lang, Grassroots at the Gateway, 23-28.

104 Mitchell, Embattled Democracy, 133.
} 
Missouri's African American population had local, state, and national implications from the 1930 s to the present. 


\section{Conclusion}

Though they had been political rivals during the 1920s, James A. Reed and Arthur M. Hyde shared a common goal in opposing the Ku Klux Klan. Even as their political careers wound down in the 1930s, they continued to keep a close eye on issues of intolerance. In spring 1933, they put aside their political differences once more and appealed to humanity. After Adolf Hitler became the chancellor of Germany, Reed and Hyde appeared together before a large crowd in Kansas City to speak out against Nazism. Hitler's rise to power concerned Reed, and he told those assembled that "no man ever sought dictatorial power who was not in his heart a monster." Hyde shared the sentiment, and warned the crowd that "persecution of Jews by those who call themselves Christians does Christianity an evil service." 1 For both men, their condemnation of anti-Semitism and intolerance was not new. Yet, with a new enemy on the horizon, the time had come, in the eyes of men like Reed and Hyde, to launch a "double-barreled attack on Hitlerism." In later remarks to the Committee for the Defense of Human Rights Against Nazism, Reed made it clear that he planned to attack Nazism, both in the United States and abroad, just as he had done against the Klan a decade earlier because "[t]oday, it is the Jew who is the particular victim. But tomorrow, and tomorrow, and tomorrow, the

\footnotetext{
${ }^{1}$ Jefferson City Post-Tribune, 28 March 1933; Weekly Kansas City Star, 29 March 1933.

2 Los Angeles Times, 9 April 1934; St. Louis Star-Times, 9 April 1934; Jefferson City Post-Tribune, 9 April 1934; Kansas City Journal-Post, 9 April 1934.
} 
waves may break higher and higher upon the shores, until they may engulf all lands and all peoples."3

By the time of Reed's and Hyde's comments on Nazism in the mid-1930s, the $\mathrm{Ku}$ Klux Klan was a shell of its former self. It had ridden to great prominence in American society during the 1920s with an estimated membership of close to five million. In communities throughout the United States, the Klan had gained tremendous membership while also inflicting its moral reform ideals upon local politics. Yet, scandals involving prominent Klansmen, as well as failed political mobilization in some parts of the country, hastened the decline of the hooded order. By the mid-1930s, the Klan existed largely in name only with roughly a few thousand members scattered around the United States. As it would do at various points in its continuing life cycle, the Klan attached itself to issues of racial and religious strife in an effort for relevance, such as an alliance with Nazi sympathizers during the Great Depression. However, facing internal fracture following the resignation of Imperial Wizard Hiram Evans, as well as allegations from the federal government of failure to pay taxes, the Ku Klux Klan officially disbanded during World War II.

\footnotetext{
${ }^{3}$ The transcript of James A. Reed's speech can be found in Box 42 of the James Alexander Reed Papers at the State Historical Society of Missouri. The direct quote used here come from pages 6-8. For correspondence between Reed and the Committee for the Defense of Human Rights Against Nazism see Jacob Billikopf to James A. Reed, 8 November 1933, Folder 11, Box 41, James Alexander Reed Papers, State Historical Society of Missouri, Kansas City, Missouri; James M. Yard to James A. Reed, 23 March 1934, Folder 11, Box 41, James Alexander Reed Papers, State Historical Society of Missouri, Kansas City, Missouri; James M. Yard to James A. Reed, 27 March 1934, Folder 11, Box 41, James Alexander Reed Papers, State Historical Society of Missouri, Kansas City, Missouri; James M. Yard to James A. Reed, 27 March 1934, Western Union Telegram, Folder 11, Box 41, James Alexander Reed Papers, State Historical Society of Missouri, Kansas City, Missouri; Salmon O. Levinson to James A. Reed, 9 March 1934, Folder 11, Box 41, James Alexander Reed Papers, State Historical Society of Missouri, Kansas City, Missouri.
} 
The fight undertaken by so many anti-Klan activists to defeat the Invisible Empire had taken much longer than expected, but many of them must have felt a sense of relief with the Klan's formal disbandment. By the 1940s, many of these former Klan fighters had gone on to prominent careers, some even tied to their earlier activism from the 1920s. Despite being out of office for the latter half of the 1920s, Arthur Hyde still held a firm grasp on state Republican politics by the dawn of the Great Depression. He practiced law in his hometown of Trenton, Missouri, before President Herbert Hoover selected him to serve as Secretary of Agriculture. Hyde stayed in Hoover's cabinet for the length of the administration and remained a beloved figure in many Missouri communities. After spending most of his time engulfed in agrarian issues associated with the Great Depression, Hyde left Washington D.C. following Hoover's defeat in 1932. He continued to be active in state Republican politics throughout the 1930s and 1940s before passing away in $1947 .^{4}$

Across the political aisle, James A. Reed failed in his bid to secure the Democratic nomination from president in 1928, and opted to retire from the U.S. Senate in 1929. Mourning his departure from public office, H.L. Mencken of the American Mercury lamented that it was "a great pity that there are not more like him. ${ }^{5} \mathrm{He}$ contemplated one final run for the White House in 1932, but Franklin Delano Roosevelt stood in his way. While never retreating from the Democratic Party, Reed became an ardent critic of Roosevelt and his New Deal. A vocal proponent of states' rights, Reed helped organize the National Jeffersonian Democrats in 1936 as a wing of the party to

\footnotetext{
${ }^{4}$ Christensen, Foley, Kremer, and Winn, Dictionary of Missouri Biography, 418-419.

${ }^{5}$ American Mercury, April 1929.
} 
oppose Roosevelt's bid for re-election. Having failed to unseat him in 1936, Reed's group continued to speak out against Roosevelt's liberalism until the senator's death in $1944 .{ }^{6}$

James Reed's former Democratic colleague in the Senate, Harry Hawes, served in that body until 1932. Though the odds were good that he would win re-election in the Democratic resurgence that accompanied Franklin Delano Roosevelt's bid for the White House, Hawes served only one term before opting not to seek re-election. In his retirement, Hawes continued to devote attention to issues he fought for in Congress, including environmental issues and Filipino nationhood. The latter was an outgrowth of his legal work with the Philippine Commonwealth in the years leading up to the Japanese invasion in 1941. His concerns about the environment led him to take an active role in the development of a Conservation Commission in Missouri. He died in 1947. ${ }^{7}$

As Hyde, Hawes, and Reed rode off into the political sunset, Allen McReynolds used his connections in the local bar association and the Jasper County Anti-Klan Association to launch a successful bid for the Missouri General Assembly. After winning a seat in the state senate in 1934, McReynolds contemplated a run for governor in 1940 on the Democratic Ticket, but he failed to make it through the party primary. Despite this defeat, McReynolds served as a delegate at the state's constitutional convention of 19431944. At the close of World War II, which also coincided with the end of his own political career, Governor Phil M. Donnelly appointed him to the University of Missouri's Board of Curators. During his time on the board, he served as president and

\footnotetext{
${ }^{6}$ Christensen, Foley, Kremer, and Winn, Dictionary of Missouri Biography, 641-643.

${ }^{7}$ Lawrence O. Christensen, William E. Foley, Gary R. Kremer, and Kenneth H. Winn, eds., Dictionary of Missouri Biography (Columbia: University of Missouri Press, 1999), 385-386
} 
was involved in the eventual desegregation of the university in 1950. After he left the Board of Curators in 1951, construction began on McReynolds Hall on the University of Missouri's Columbia campus. McReynolds died in $1960 .^{8}$

While McReynolds chaired the Board of Curators during the contentious fight to desegregate the University of Missouri at the dawn of the 1950s, George L. Vaughn's concern for this goal dated back much farther to the Gaines $v$. Canada case. ${ }^{9}$ By the end of the 1920s, Vaughn had joined many other African Americans in St. Louis in their realignment to the Democratic Party. To this end, Vaughn failed in a bid for the U.S. Congress, but did win election as a Justice of the Peace in 1936. He remained active in the local NAACP throughout the remainder of his life. He served as an Assistant Attorney General for the state, and later as counsel for J.D. Shelley in a restrictive covenant case involving a St. Louis real estate association. After the Missouri State Supreme Court upheld the legality of the restrictive covenant that attempted to evict Shelley and his family from their home, Vaughn appealed the case to the United States Supreme Court. In 1948, the United States Supreme Court ruled in the now famous Shelley v. Kraemer case that state courts could not enforce racially restrictive covenants because of the equal protection clause of the $14^{\text {th }}$ Amendment. Thurgood Marshall got

\footnotetext{
${ }^{8}$ Christensen, Foley, Kremer, and Winn, Dictionary of Missouri Biography, 542-543.

${ }^{9}$ A graduate of Missouri's all black Lincoln University in 1936; Lloyd Gaines applied for admission to the University of Missouri Law School. After being denied acceptance, Gaines and the NAACP sued the university. The state court system upheld this denial. As a result, the case was taken before the United States Supreme Court in 1938. The Supreme Court sided with Gaines and ordered the University of Missouri to admit Gaines or provide equal facilities for students of color. The university opted to establish a law school at Lincoln University to avoid integration. Soon after, Lloyd Gaines disappeared while living out of state and was never seen again. For general information on the Gaines case see Greene, Kremer, and Holland, Missouri's Black Heritage, 155; Schirmer, A City Divided, 176; Sullivan, Lift Every Voice, 230233, 250. A detailed study of the Gaines case can be found in James W. Endersby and William T. Horner, Lloyd Gaines and the Fight to End Segregation (Columbia: University of Missouri Press, 2016).
} 
the credit for the decision based upon his legal work with the Detroit-based McGhee v. Sipes case that consolidated into Shelley, but Vaughn did the behind the scenes work to bring the case before the United States Supreme Court. Not long after his victory in the Supreme Court, Vaughn challenged white supremacy by calling upon the Democratic National Committee to not sit the all-white Mississippi delegation at the 1948 convention, but his argument was overruled. A year after his triumph in Shelley $v$. Kraemer, Vaughn passed away. ${ }^{10}$

George L. Vaughn's attempts to improve civil rights in St. Louis often received the backing of J.E. Mitchell. In fact, both men proved to be influential in the continual realignment of African American voters from the Republicans to the Democrats in the city, though Mitchell did support Herbert Hoover in 1932. That same year, Mitchell won election as the president of the St. Louis NAACP. He only served one term, but his work as the head of the organization changed it into a more active group than even its Klanfighting years, and made him a notable figure in the state. Historian Debra Foster Greene notes that Mitchell's “consistency and political activism during the 1920s" earned him attention from state officials. After briefly joining A. Philip Randolph's March on Washington Movement during World War II, Mitchell received an appointment to the St. Louis Race Relation Commission and Governor Phil M. Donnelly named him to the State Board of Education. He did all of this while still managing the Argus, as he had done

${ }^{10}$ Christensen, Foley, Kremer, and Winn, Dictionary of Missouri Biography, 769-770; Lang, Grassroots at the Gateway, 39, 46-47, 78; Gordon, Mapping Decline, 81-84; Greene, Kremer, and Holland, Missouri's Black Heritage, 163-165; Dowden-White, Groping Toward Democracy, 55. For more information on George L. Vaughn, Shelley v. Kraemer, and legal challenges to restrictive covenants see Jeffrey D. Gonda, Unjust Deeds: The Restrictive Covenant Cases and the Making of the Civil Rights Movement (Chapel Hill: University of North Carolina Press, 2015). 
since the 1910s, though by the late 1940s Mitchell's health began to fade. He died in $1952 .^{11}$

Across the state, in Kansas City, C.A. Franklin replicated the civil rights activism of Mitchell and Vaughn. He supported the efforts of Lucile Bluford, an employee of the Kansas City Call, in her attempts to desegregate the University of Missouri. ${ }^{12}$ Not solely wanting to focus on desegregation of educational institutions, Franklin also turned his attention to unfair employment practices, particularly in the defense industry. He pressed fellow Kansas Citian Harry S. Truman, now a senator in Washington D.C., to improve these conditions. Though never wavering from the Republican Party, Franklin kept close correspondence with Truman throughout the 1930s and promoted the civil rights work of the senator in the pages of the Call. However, this relationship evaporated by the 1940s, especially after the Call participated in the smear campaign that re-invigorated claims that Truman had joined the Klan during the 1920s. Franklin knew the story to be untrue, but his association with the Republican efforts dampened his ties to Truman. After watching Truman win election as president in 1948, despite his support for Republican

${ }^{11}$ Greene, Published in the Interest of Colored People, 110-148. For more information on the March on Washington Movement and its activities in St. Louis see David Lucander, Winning the War for Democracy: The March on Washington Movement, 1941-1946 (Urbana: University of Illinois Press, 2014) and Lang, Grassroots at the Gateway, 43-68.

12 Lucile Bluford replaced Roy Wilkins at the Call after he accepted a position with the NAACP. In 1938, Bluford applied for graduate admission to University of Missouri's School of Journalism. She was initially accepted, but when she tried to enroll, she was denied. She later filed suit against the university. In 1941, the Missouri State Supreme Court ruled in her favor and required her admittance. The university closed its graduate program in journalism citing a lack of teachers and resources due to the outbreak of World War II. Bluford returned to the Call and later served as its manager after the retirement of C.A. Franklin. For information on the Bluford case see Greene, Kremer, and Holland, Missouri's Black Heritage, 155-156; Schirmer, A City Divided, 176-177; Sullivan, Lift Every Voice, 250-253. 
Thomas Dewey, Franklin retired from the Call citing health reasons. He passed away in $1955^{13}$

Roy Wilkins, the young editor hired by C.A. Franklin in the early 1920 s, did not stay in Kansas City long. Having fought segregation, discrimination, and the Klan in Kansas City through the pages of the Call, Wilkins soon found opportunities well outside the Midwest by the end of the decade. His writings in the Call caught the attention of the NAACP, and Wilkins was offered the position of Assistant Secretary. By 1934, Wilkins also served as the chief editor of The Crisis. Throughout World War II and into the 1950s, Wilkins worked closely with other officials in the NAACP to promote legal challenges against Jim Crow. In the wake of the Brown v. Board of Education decision, and only months before the Montgomery Bus Boycott, Wilkins became the NAACP's Executive Secretary (later Executive Director). In this role, Wilkins led the NAACP during the heart of the Civil Rights Movement, though he preferred that the organization promote integration and stay away from what he saw as radical desegregation. As he had done earlier in his life as a young member of the NAACP, Wilkins openly repudiated bigots and Klansmen by participating in the 1963 March on Washington and the Selma to Montgomery marches. President Lyndon Johnson awarded Wilkins the Presidential Medal of Freedom in 1967 for his civil rights career. He retired from the NAACP in 1977 and died four years later. ${ }^{14}$

\footnotetext{
${ }^{13}$ Wilson, "Chester A. Franklin and Harry S. Truman," 62-76; Christensen, Foley, Kremer, and Winn, Dictionary of Missouri Biography, 316-317.

${ }^{14}$ Wilkins, Standing Fast, 103-343; Ryan, Roy Wilkins, 12-200; Sullivan, Lift Every Voice, 152-153, 373-375; Christensen, Foley, Kremer, and Winn, Dictionary of Missouri Biography, 798-800.
} 
Having fought anti-Catholicism since the early $20^{\text {th }}$ century, Luke E. Hart had no plans to stop with the decline of the Ku Klux Klan in the 1930s. Instead, he turned his attention to the continual publication of the so-called "bogus oath." Surprisingly, despite the Klan's near-disappearance, Hart stayed busy in his role as Supreme Advocate for the Knights of Columbus, particularly when it came to litigation against peddlers of the bogus oath. Hart regularly advised local chapters of the Knights of Columbus on how best to combat distribution of the bogus oath well into the 1960 s. $^{15}$ When it came to civil rights issues, historian Christopher Kauffman argues that Hart was "far from an enthusiastic integrationist." ${ }^{16}$ His prior work with the NAACP during the 1920s did influence his racial views, but Hart had to admit to confidants that the Knights of Columbus had no African American members by the mid-1940s. ${ }^{17}$ When pressed on what he could do to change this lack of diversity, Hart asserted that integration of the organization would be a "worth while activity." 18 Civil rights activists, however, pointed out the lack of motivation by Knights of Columbus officials to pursue integration. Hart agreed with this assessment, but acknowledged that membership was left up to individual councils and they were "answerable only to their conscience."19 Nevertheless, after his election as Supreme Knight (the highest position in the organization) in 1953, Hart

\footnotetext{
${ }^{15}$ Kauffman, Faith and Fraternalism, 374-397.

${ }^{16}$ Kauffman, Faith and Fraternalism, 396.

${ }^{17}$ R.P. Cummins to Luke E. Hart, 24 April 1947, Folder 273, Box 231, Luke E. Hart Supreme Advocate Records (hereafter cited LH), Knights of Columbus Supreme Council Archives (hereafter cited (KCSCA), New Haven, Connecticut; Luke E. Hart to R.P. Cummins, 28 April 1947, Folder 273, Box 231, LH, KCSCA.

${ }^{18}$ Luke E. Hart to Francis J. Heazel, 27 January 1941, Folder 272, Box 231, LH, KCSCA.

${ }^{19}$ Luke E. Hart to R.P. Cummins, 28 April 1947, Folder 273, Box 231, LH, KCSCA.
} 
pushed for greater diversity among members. He died in 1964, living long enough to see John F. Kennedy, a Catholic, elected President of the United States. ${ }^{20}$

While all of the above mentioned individuals became quite prominent both during and after their 1920s activism, some even making a lengthy career out of combatting intolerance, many of the men and women who challenged the Ku Klux Klan in Missouri did so with little fame and recognition outside of their local communities. For them, the fight against the Klan was a daily battle of racial, religious, and civic identity. As has been shown, attempts by various anti-Klan individuals and groups to form a united front against the Klan largely failed during the decade. Nevertheless, they were successful in rendering the hooded order into a relatively powerless organization at the state level.

However, what happened after this Klan fight is also just as important. For some, like George L. Vaughn, J.E. Mitchell, C.A. Franklin, and Roy Wilkins, their anti-Klan work was just one phase of their activism. In many ways, they fought against the Klan as part of a larger focus on civil rights. As such, they cut their teeth as civil rights activists during the anti-Klan campaign, and used this experience as they rose to later prominence during the long civil rights movement. For others, like James A. Reed, Harry Hawes, Arthur Hyde, and Allen McReynolds, their anti-Klan sentiments were closely tied to politics and political mobilization. While they may have genuinely opposed the Klan's ideology, they were not without their own prejudices and intolerances. The African American press, in its critique of each man's political relationship with the state's black community, repeatedly brought up this point. However, to simply say that these men were anti-Klan because the political winds steered them that way overlooks the lengths to

\footnotetext{
${ }^{20}$ Kauffman, Faith and Fraternalism, 374-397.
} 
which each man went to portray to voters and constituents that a vote for them was a vote against the Klan. Finally, some individuals who fought the Klan did so for personal reasons, whether racial, religious, economic, social, or political. Luke E. Hart was part of this group. As a Catholic, he opposed the Klan's anti-Catholicism. Yet, he also stood up on behalf of others who the Klan ostracized. The same cannot be said for all anti-Klan activists, including those who fought the hooded order during the 1920s while at the same time promoting white supremacy and later actively speaking out against the post-World War II civil rights movement.

Ultimately, despite their successful battles against the Klan, anti-Klan activists lost the long-term war. Simply put: the Ku Klux Klan still exists today. The Klan may have been on a steep decline by the 1930s, but it did not disappear from American life. Nor did most former Klansmen and -women suffer personal ruin from their ties to the Invisible Empire. After interviewing former Klanswomen more fifty years after their time in the hooded order, Kathleen Blee found that many expressed "pride, not regret" because they found "their member in one of U.S. history's most vicious campaigns of prejudice and hatred primarily as a time of friendship and solidarity among like-minded women."21 In Missouri, William M. Campbell and Heber Nations both remained active figures in their communities. Campbell was considered one of St. Joseph's most respected doctors at the time of his death in $1953 .^{22}$ Nations, though suffering considerable negative attention for his role in the graft scandal, stayed active in politics throughout the 1930s and 1940s. He was a lobbyist for the Missouri Corporation and

\footnotetext{
${ }^{21}$ Blee, Women of the Klan, 1.

22 St. Joseph News-Press, 13 June 1953; St. Louis Post-Dispatch, 14 June 1953.
} 
Information Bureau for several years, and later voiced opposition to a new state constitution. ${ }^{23}$ Due to significant racialized backlash to the civil rights movement, the Klan grew stronger in the postwar years. It influenced politicians, opposed integration, and murdered civil rights activists. No longer a centralized Klan like it had been in the 1920s, this resurgent group of Klans was a fractured collection of organizations developed within a larger white supremacist movement that drew in members from various walks of life.

In addition, many Americans shared the Klan's views on racial and religious issues, even if they refused to don hoods and robes to make these points. Instead of burning crosses, they wrote scorching editorials in newspapers against civil rights and integration. Instead of speaking on the tenets of the hooded order in public venues, they secretly passed similar literature to friends, confidants, and co-workers. Instead of visibly joining the ranks of the Invisible Empire, they hid their beliefs behind a veneer of respectability. Through all of this, and because of all of this, the Klan remains active in American society even as its membership numbers stay relatively small. And yet, though the Klan continues to rise like a phoenix out of the ashes of its own burned out crosses, anti-Klan activists continue to organize and mobilize against the Invisible Empire. They may not know the historical significance of their opposition, or its connections to the long civil rights movement, but perhaps, that is a story worth telling.

\footnotetext{
${ }^{23}$ St. Louis Post-Dispatch, 11 March 1948.
} 


\section{Bibliography}

\section{PRIMARY SOURCES}

Newspapers:

American Mercury

APA Magazine

Arkansas Gazette

Ashland Bugle

Atlanta Constitution

Auxvasse Review

Bloomfield Vindicator

Boonville Weekly Advertiser

Campbell Citizen

Cape Girardeau Southeast Missourian

Carthage Evening Press

Caruthersville Democrat-Argus

Center Herald

Central-Blatt and Social Justice

Central Missouri Republican

Centralia Courier

Charleston Enterprise-Courier

Chicago Daily Tribune

Chicago Defender

Church Progress

Cole County Weekly Rustler

Columbia Daily Tribune 
Columbia Herald Statesman

Columbia Missourian

Des Moines Register

Detroit Free Press

Dexter Statesman

Dunklin County News

East Prairie Eagle

Fayette Advertiser

Fayette Democrat-Leader

Fulton Daily Sun

Fulton Gazette

Fulton Telegraph

Hannibal Courier-Post

Hayti Missouri Herald

Jasper County Democrat

Jefferson City Daily Capital News

Jefferson City Daily Post

Jefferson City Democrat Tribune

Jefferson City Missouri State Times

Jefferson City People's Tribune

Jefferson City Tribune

Joplin Globe

Joplin News-Herald

Kansas City Call

Kansas City Catholic Register

Kansas City Jewish Chronicle 
Kansas City Journal-Post

Kansas City Star

Kansas City Times

Lexington Intelligencer

Lexington Weekly Caucasian

London Times

Los Angeles Times

Malden Merit

Marion County Herald

Mexico Daily Ledger

Missouri Cash-Book

Missouri Counselor

Missouri Klan Kourier

Missouri Valley Independent

Moberly Monitor-Index

Mokane Missourian

Negro World

New Madrid Weekly Record

New York Age

New York Herald

New York Times

New York Tribune

New York World

Opportunity

Palmyra Spectator 
Pittsburgh Courier

Sikeston Standard

Springfield Leader

St. Joseph Catholic Tribune

St. Joseph Gazette

St. Joseph News-Press

St. Joseph Observer

St. Louis Argus

St. Louis Globe-Democrat

St. Louis Jewish Voice

St. Louis Post-Dispatch

St. Louis Star

Stoddard Tribune

Tennessean

The Crisis

The Imperial Night-Hawk

The Kourier Magazine

The Menace

The Modern View

The New Menace

The Savitar

The Patriot

Union Signal

Versailles Statesman

Vienna Home-Advisor

Western Watchman 
$\underline{\text { Records Collections/Documents: }}$

Annual Report, Woman's Christian Temperance Union of the State of Missouri, Volumes: 1-53. St. Louis: n.p., 1883-1935, State Historical Society of Missouri, Columbia, Missouri.

Anti-Catholic Printed Material Collection, University Archives, Hesburgh Library, University of Notre Dame, South Bend, Indiana.

Anti-Catholicism Record Group, Knights of Columbus Supreme Council Archives, New Haven, Connecticut.

Frank Ely Atwood, Papers, State Historical Society of Missouri, Columbia, Missouri.

Luther Lee Bernard, Papers, Special Collections Research Center, University of Chicago, Chicago, Illinois.

Edwin Bayer Branson, Papers, State Historical Society of Missouri, Columbia, Missouri.

Benjamin Gratz Brown, Missouri Governors Collection, Missouri State Archives, Jefferson City, Missouri.

Catholic Central Verein Collection, University Archives, Hesburgh Library, University of Notre Dame, South Bend, Indiana.

Perl D. Decker, Papers, State Historical Society of Missouri, Columbia, Missouri.

Charles A. Ellwood, Papers, University Archives, Rubenstein Library, Duke University, Durham, North Carolina.

First Christian Church, Jefferson City, MO, Cole County, Minutes of Board, 1921-1930, First Christian Church, Jefferson City, MO.

First Presbyterian Church, Jefferson City, MO, Cole County, Minutes of Session, Missouri State Archives, Jefferson City, MO.

Thomas Clement Fletcher, Missouri Governors Collection, Missouri State Archives, Jefferson City, Missouri.

Gentry Family, Papers, State Historical Society of Missouri, Columbia, Missouri.

Luke E. Hart Supreme Advocate Records, Knights of Columbus Supreme Council Archives, New Haven, Connecticut.

House Committee on Rules, The Ku-Klux Klan: Hearing before the Committee on Rules, $67^{\text {th }}$ Cong., $1^{\text {st }}$ sess., 1921. 
Arthur Mastick Hyde, Papers, State Historical Society of Missouri, Columbia, Missouri.

Knights of the Ku Klux Klan, Inc. Proceedings of the Second Imperial Klonvokation: Held in Kansas City, Missouri, Sept. 23, 24, 25 and 26, 1924 (n.p., n.d.).

Ku Klux Klan Collection, Archives and Special Collections, University Libraries, Ball State University, Muncie, Indiana.

Ku Klux Klan Collection, Rubenstein Library, Duke University, Durham, North Carolina.

Joseph Washington McClurg, Missouri Governors Collection, Missouri State Archives, Jefferson City, Missouri.

William Fletcher McMurry, Papers, State Historical Society of Missouri, Columbia, Missouri

National Association for the Advancement of Colored People Records, Library of Congress, Washington D.C.

Matthew K. Partin Collection, State Historical Society of Missouri, Kansas City, Missouri.

Polk's Jefferson City Directory, 1925 (Chicago: R.L. Polk \& Co., 1925)

Records of the Democratic National Committee, Harry S. Truman Library \& Museum, Independence, Missouri.

James Alexander Reed, Papers, State Historical Society of Missouri, Kansas City, Missouri.

Charles Malone Reeves, Papers, State Historical Society of Missouri, Columbia, Missouri.

Harry Schneiderman, ed., The American Jewish Year Book 5681, September 13, 1920 to October 2, 1921, Volume 22. Philadelphia: The Jewish Publication Society of America, 1920.

Stuart A. Rice, Papers, Harry S. Truman Library \& Museum, Independence, Missouri.

Saint Louis Urban League, Files, Missouri State Archives, Jefferson City, MO.

Frank Fletcher Stephens, Papers, State Historical Society of Missouri, Columbia, Missouri.

William Joel Stone, Missouri Governors Collection, Missouri State Archives, Jefferson City, Missouri. 
University of Missouri, President's Office, Papers, State Historical Society of Missouri, Columbia, Missouri.

U.S. Bureau of the Census, Thirteenth Census of the United States: 1910, vol. 2: Population

U.S. Bureau of the Census, Fourteenth Census of the United States: 1920, vol. 2: Population

Silas Woodson, Missouri Governors Collection, Missouri State Archives, Jefferson City, Missouri.

\section{Oral History Interviews}

Aylward, James P. 1968. Interview by James R. Fuchs, 27 June. Tape Recording. Oral History Interviews, Harry S. Truman Library \& Museum, Independence, Missouri.

Babcock, Gaylon. 1964. Interview by James R. Fuchs, 12 February. Tape Recording. Oral History Interviews, Harry S. Truman Library \& Museum, Independence, Missouri.

Connelly, Matthew J. 1967. Interview by Jerry N. Hess, 28 November. Tape Recording. Oral History Interviews, Harry S. Truman Library \& Museum, Independence, Missouri.

Daniels, Jonathan. 1963. Interview by James R. Fuchs, 4 October. Tape Recording. Oral History Interviews, Harry S. Truman Library \& Museum, Independence, Missouri.

Donnelly, Eugene and Edward Meisburger. 1975. Interview by William D. Stilley and Jerald L. Hill, 27 December. Tape Recording. Oral History Interviews, Harry S. Truman Library \& Museum, Independence, Missouri.

Evans, Tom L. 1962. Interview by James R. Fuchs, 8 August, 28 November. Tape Recording. Oral History Interviews, Harry S. Truman Library \& Museum, Independence, Missouri.

Hinde, Edgar G. 1962. Interview by James R. Fuchs, 15 March. Tape Recording. Oral History Interviews, Harry S. Truman Library \& Museum, Independence, Missouri. 
Holeman, Frank. 1987. Interview by Niel M. Johnson, 9 June. Tape Recording. Oral History Interviews, Harry S. Truman Library \& Museum, Independence, Missouri.

Howard, May C. 1985. Interview by Niel M. Johnson, 19 August. Tape Recording. Oral History Interviews, Harry S. Truman Library \& Museum, Independence, Missouri.

McKim, Edward D. 1964. Interview by James R. Fuchs, 17 February. Tape Recording. Oral History Interviews, Harry S. Truman Library \& Museum, Independence, Missouri.

Nash, Philleo. 1966. Interview by Jerry N. Hess, 18 October. Tape Recording. Oral History Interviews, Harry S. Truman Library \& Museum, Independence, Missouri.

Noland, Mary Ethel. 1965. Interview by James R. Fuchs, 9 September. Tape Recording. Oral History Interviews, Harry S. Truman Library \& Museum, Independence, Missouri.

Peters, Mize. 1963. Interview by James R. Fuchs, 21 August. Tape Recording. Oral History Interviews, Harry S. Truman Library \& Museum, Independence, Missouri.

Sanders, Ted J. 1982. Interview by Niel M. Johnson, 23 July. Tape Recording. Oral History Interviews, Harry S. Truman Library \& Museum, Independence, Missouri.

Sweeney, Robert L. 1977. Interview by Carol A. Briley, 12 December. Tape Recording. Oral History Interviews, Harry S. Truman Library \& Museum, Independence, Missouri.

Trohan, Walter. 1970. Interview by Jerry N. Hess, 7 October. Tape Recording. Oral History Interviews, Harry S. Truman Library \& Museum, Independence, Missouri.

\section{SECONDARY SOURCES}

Alexander, Charles C. The Ku Klux Klan in the Southwest. Lexington: University of Kentucky Press, 1965.

Allen, Frederick L. Only Yesterday: An Informal History of the 1920s. New York: Harper Collins Publishers, 2000. 
Anbinder, Tyler. Nativism and Slavery: The Northern Known Nothings and the Politics of the 1850s. Oxford: Oxford University Press, 1992.

Anderson, Carol. White Rage: The Unspoken Truth of Our Racial Divide. New York: Bloomsbury, 2016.

Angle, Paul M. Bloody Williamson: A Chapter in American Lawlessness. New York: Knopf, 1952.

Arenson, Adam. The Great Heart of the Republic: St. Louis and the Cultural Civil War. Cambridge: Harvard University Press, 2011.

Aron, Stephen. American Confluence: The Missouri Frontier from Borderland to Border State. Bloomington: Indiana University Press, 2009.

Astor, Aaron. Rebels on the Border: Civil War, Emancipation, and the Reconstruction of Kentucky and Missouri. Baton Rouge: Louisiana State University Press, 2012.

Baker, Kelly J. Gospel according to the Klan: the KKK's Appeal to Protestant America, 1915-1930. Lawrence: University of Kansas, 2011.

Barnes, Harper. Never Been a Time: The 1917 Race Riot That Sparked the Civil Rights Movement. New York: Walker \& Company, 2008.

Barnes, Kenneth. Anti-Catholicism in Arkansas: How Politicians, the Press, the Klan, and Religious Leaders Imagined an Enemy, 1910-1960. Fayetteville: University of Arkansas Press, 2016.

Bennett, David H. The Party of Fear: The American Far Right from Nativism to the Militia Movement. New York: Vintage, 1995.

Blee, Kathleen M. Women of the Klan: Racism and Gender in the 1920s. Berkeley: University of California Press, 1991.

Blumer, Herbert. George Herbert Mead and Human Contact. New York: Altamira Press, 2004.

Blumer, Herbert. "Race Prejudice as a Sense of Group Position." The Pacific Sociological Review 1 No. 1 (1958): 3-7.

Blumer, Herbert. Theory of Social Revolutions. Master's thesis, University of Missouri, 1922.

Bordin, Ruth. Frances Willard: A Biography. Chapel Hill: University of North Carolina Press, 1986. 
Bordin, Ruth. Woman and Temperance: The Quest for Power and Liberty, 1873-1900. Philadelphia: Temple University Press, 1981.

Brock, Frederick E. The American Party in Missouri, 1854-1860. Master's Thesis, University of Missouri-Columbia, 1949.

Butts-Runion, B. Blanche. "Through the Years": A History of the First Seventy-Five Years of the Woman's Christian Temperance Union of Missouri, 1882-1957. n.p. 1957.

Carroll, Andrew. My Fellow Soldiers: General John Pershing and the Americans who helped win the Great War. New York: Penguin Press, 2017.

Chalmers, David M. Hooded Americanism: the History of the Ku Klux Klan. Chicago: Quadrangle Books, 1968.

Christensen, Lawrence O. and Gary Kremer. A History of Missouri: Volume IV, 1875 to 1919. Columbia: University of Missouri Press, 1997.

Christensen, Lawrence O. "Race Relations in St. Louis, 1865-1916." Missouri Historical Review 78, no. 2 (January 1984): 123-136.

Christensen, Lawrence O., William E. Foley, Gary R. Kremer, and Kenneth H. Winn, eds., Dictionary of Missouri Biography. Columbia: University of Missouri Press, 1999.

Curcio, Vincent. Henry Ford. Oxford: Oxford University Press, 2013.

DeArmond, Fred. "Reconstruction in Missouri." Missouri Historical Review 61, no. 3 (April 1967): 364-377.

Dinnerstein, Leonard. Antisemitism in America. Oxford: Oxford University Press, 1994.

Dorr, Jeffrey R. Race in St. Louis' Catholic Church: Discourse, Structures, and Segregation, 1873-1941. MA Thesis, St. Louis University, 2015.

Dowden-White, Priscilla A. Groping Toward Democracy: African American Social Welfare Reform in St. Louis, 1910-1949. Columbia: University of Missouri Press, 2011.

Dumenil, Lynn. The Modern Temper: American Culture and Society in the 1920s. New York: Hill \& Wang, 1995.

Earle, Jonathan and Diane Mutti Burke. eds. Bleeding Kansas, Bleeding Missouri: The Long Civil War on the Border. Lawrence: University of Kansas Press, 2013. 
Efford, Alison. German Immigrants, Race, and Citizenship in the Civil War Era. Cambridge: Cambridge University Press, 2013.

Ehrlich, Walter. Zion in the Valley: The Jewish Community in St. Louis, Volume I, 18071907. Columbia: University of Missouri Press, 1997.

Ehrlich, Walter. Zion in the Valley: The Jewish Community of St. Louis, Volume II, The Twentieth Century. Columbia: University of Missouri Press, 2002.

Epps, Kristen. Slavery on the Periphery: The Kansas-Missouri Border in the Antebellum and Civil War Eras. Athens: University of Georgia Press, 2016.

Ervin, Keona K. Gateway to Equality: Black Women and the Struggle for Economic Justice in St. Louis. Lexington: University Press of Kentucky, 2017.

Flaherty, William. Dream by the River: Two Centuries of Saint Louis Catholicism, 17661980. St. Louis: River City publishers, 1981.

Flaherty, William Barnaby. "Nativism and Midwestern Education: The Experience of St. Louis University, 1832-1856," History of Education Quarterly 8, no. 4 (Winter, 1968): 447-458.

Ferrell, Robert H. Harry S. Truman: A Life. Columbia: University of Missouri Press, 1994.

Foner, Eric. Reconstruction: America's Unfinished Revolution, 1863-1877. New York: Harper \& Row, 1988.

Ford, James E. A History of Jefferson City: Missouri's State Capital, and of Cole County. Jefferson City, MO: The New Day Press, 1938.

Fox, Craig. Everyday Klansfolk: White Protestant Life and the KKK in 1920s Michigan. East Lansing: Michigan State University Press, 2011.

Francis, Megan Ming. Civil Rights and the Making of the Modern American State. Cambridge: Cambridge University Press, 2014.

Frazier, Harriet C. Lynchings in Missouri, 1803-1981. Jefferson, N.C.: McFarland \& Co., 2009.

Fry, Henry P. The Modern Ku Klux Klan. Boston: Small and Maynard, 1922.

Gerber, David A. ed. Anti-Semitism in American History. Urbana: University of Illinois Press, 1986. 
Gerlach, Larry R. Blazing Crosses in Zion: the Ku Klux Klan in Utah. Logan: Utah State University Press, 1982.

Gilmore, Glenda Elizabeth. Defying Dixie: The Radical Roots of Civil Rights, 1919-1950. New York: W.W. Norton \& Company, 2008.

Gilmore, Glenda Elizabeth. Gender and Jim Crow: Women and the Politics of White Supremacy in North Carolina, 1896-1920. Chapel Hill: University of North Carolina Press, 1996.

Gleason, Philip. The Conservative Reformers: German-American Catholics and the Social Order. South Bend, University of Notre Dame Press, 1968.

Goldberg, David. Discontented America: The United States in the 1920s. Baltimore: Johns Hopkins University Press, 1999.

Goldberg, David J. "Unmasking of the Ku Klux Klan: The Northern Movement against the KKK, 1920-1925." Journal of American Ethnic History 15, no. 4 (Summer, 1996): 32-48.

Goldberg, Robert A. Hooded Empire: the Ku Klux Klan in Colorado. Urbana: University of Illinois Press, 1981.

Gonda, Jeffrey D. Unjust Deeds: The Restrictive Covenant Cases and the Making of the Civil Rights Movement. Chapel Hill: University of North Carolina Press, 2015.

Gordon, Colin. Mapping Decline: St. Louis and the Fate of the American City. Philadelphia: University of Pennsylvania Press, 2008.

Gordon, Linda. The Second Coming of the KKK: The Ku Klux Klan of the 1920s and the American Political Tradition. New York: Liveright, 2017.

Grant, Colin. Negro with a Hat: The Rise and Fall of Marcus Garvey. Oxford: Oxford University Press, 2008.

Greene, Debra Foster. Published in the Interest of Colored People: the St. Louis Argus Newspaper in the Twentieth Century. Ph.D. Diss., University of Missouri Columbia, 2003.

Greene, Lorenzo J., Gary R. Kremer, and Antonio F. Holland. Missouri's Black Heritage: Revised Edition. Columbia: University of Missouri Press, 1993.

Grothaus, Larry. "Kansas City Blacks, Harry Truman, and the Pendergast Machine." Missouri Historical Review 69, no. 1 (October 1974): 65-82. 
Hahn, Steven. A Nation Under Our Feet: Black Political Struggles in the Rural South from Slavery to the Great Migration. Cambridge: The Belknap Press of Harvard University Press, 2003.

Hall, Jacquelyn Dowd. "The Long Civil Rights Movement and the Political Uses of the Past," The Journal of American History 91, no. 4 (March 2005): 1233-1263.

Hamby, Alonzo. Man of the People: A Life of Harry S. Truman. New York: Oxford University Press, 1995.

Harcourt, Felix. Ku Klux Kulture: America and the Klan in the 1920s. Chicago: University of Chicago Press, 2017.

Harper, Kimberly. White Man's Heaven: The Lynching and Expulsion of Blacks in the Southern Ozarks, 1894-1909. Fayetteville: University of Arkansas Press, 2010.

Hernando, Matthew J. Faces Like Devils: The Bald Knobber Vigilantes in the Ozarks. Columbia: University of Missouri Press, 2015.

Hessler, Anne. German Jews in Small Towns in Missouri, 1850-1920. Master's Thesis: University of Missouri-Columbia, 1991.

Higham, John. Strangers in the Land: Patterns of American Nativism, 1860-1925, Second Edition. New Brunswick: Rutgers University Press, 1988.

Holland, Antonio F. Nathan B. Young and the Struggle over Black Higher Education. Columbia: University of Missouri Press, 2006.

Hornbeck, Thomas. Historical Geography of the Catholic Church in Kansas City, Missouri: 1822-1930. MA Thesis, University of Kansas, 2009.

Huber, Patrick. "The Lynching of James T. Scott: The Underside of a College Town," Gateway Heritage 12 no. 1 (1991): 1-20.

Huber, Patrick. Town Versus Gown: The James T. Scott Lynching and the Social Fracture between the University of Missouri and the larger Columbia Community. B.A. thesis, University of Missouri - Columbia, 1990.

Hughes, John Starrett. "Lafayette County and the Aftermath of Slavery, 1861-1870." Missouri Historical Review 75, no. 1 (October 1980), 51-63.

Hunt, Doug. “A Course in Applied Lynching,” The Missouri Review 27 no. 2 (2004): 122-170.

Hunt, Doug. Summary Justice: The Lynching of James Scott and the Trial of George Barkwell in Columbia, Missouri, 1923. Charleston: n.p., 2010. 
Hunter, Lloyd A. "Missouri's Confederate Leaders After the War." Missouri Historical Review 67, no. 3 (April 1973): 371-396.

Hurt, R. Douglas. Agriculture and Slavery in Missouri's Little Dixie. Columbia: University of Missouri Press, 1992.

Jackson, Kenneth T. The Ku Klux Klan in the City, 1915-1930. New York: Oxford University Press, 1967.

Jenkins, Roy. Truman. New York: Harper \& Row, 1986.

Jenkins, William D. Steel Valley Klan: the Ku Klux Klan in Ohio's Mahoning Valley. Kent: Kent State University Press, 1990.

Kauffman, Christopher. Columbianism and the Knights of Columbus: A Quincentenary History. New York: Simon \& Schuster, 1992.

Kauffman, Christopher. Faith and Fraternalism: The History of the Knights of Columbus. New York: Simon \& Schuster, 1992.

Kinney, Brandon G. The Mormon War: Zion and the Missouri Extermination Order of 1838. Yardley: Westholme Publishing, 2011.

Kinzer, Donald L. An Episode in Anti-Catholicism: The American Protective Association. Seattle: University of Washington Press, 1964.

Kirkendall, Richard S. A History of Missouri: Volume V, 1919 to 1953. Columbia: University of Missouri Press, 1986.

Kittel, Audrey Nell. The Negro Community of Columbia, Missouri. Master's thesis, University of Missouri-Columbia, 1938.

Kremer, Gary. Heartland History: Volume Three. Jefferson City: City of Jefferson, 2004.

Kremer, Gary. Race and Meaning: The African American Experience in Missouri. Columbia: University of Missouri Press, 2016.

Kremer, Gary. "William J. Thompkins: African American Physician, Politician, and Publisher." Missouri Historical Review 101, no. 3 (April 2007): 168-182.

Lacey, Jim. Pershing: A Biography. New York: Palgrave MacMillan, 2008.

Lang, Clarence. Grassroots at the Gateway: Class Politics and Black Freedom Struggle in St. Louis, 1936-75. Ann Arbor: University of Michigan Press, 2009. 
Large, John Judson. The "Invisible Empire" and Missouri Politics: the Influence of the Revived Ku Klux Klan in the Election Campaign of 1924 as reported in Missouri Newspapers. Master's thesis, University of Missouri-Columbia, 1957.

Larsen, Lawrence H. and Nancy J. Hulston. Pendergast! Columbia: University of Missouri Press, 1997.

Lay, Shawn. Hooded Knights on the Niagara: the Ku Klux Klan in Buffalo, New York. New York: New York University Press, 1995.

Lay, Shawn. ed. The Invisible Empire in the West: Toward a New Historical Appraisal of the Ku Klux Klan of the 1920s. Urbana: University of Illinois Press, 1992.

LeSueur, Stephen C. The 1838 Mormon War in Missouri. Columbia: University of Missouri Press, 1987.

Litwack, Leon F. Trouble in Mind: Black Southerners in the Age of Jim Crow. New York: Alfred A. Knopf, 1998.

Lucander, David. Winning the War for Democracy: The March on Washington Movement, 1941-1946. Urbana: University of Illinois Press, 2014.

Lumpkins, Charles. American Pogrom: The East St. Louis Race Riot and Black Politics. Athens: Ohio University Press, 2008.

MacLean, Nancy K. Behind the Mask of Chivalry: The Making of the Second Ku Klux Klan. Oxford: Oxford University Press, 1994.

McCandless, Perry. A History of Missouri: Volume II, 1820-1860. Columbia: University of Missouri Press, 1972.

McCullough, David. Truman. New York: Simon \& Schuster, 1992.

McElroy, George A. Roy Wilkins as a Journalist. Master's Thesis, University of Missouri, 1970.

McGirr, Lisa. The War on Alcohol: Prohibition and the Rise of the American State. New York: W.W. Norton \& Company, 2016.

McLaurin, Melton Alonza. Celia, A Slave. Athens: University of Georgia Press, 1991.

McVeigh, Rory. The Rise of the Ku Klux Klan: Right-Wing Movements and National Politics. Minneapolis: University of Minnesota Press, 2009.

Manfra, Jo A. "Hometown Politics and the American Protective Association, 18871890," The Annals of Iowa 55 (1996), 138-166. 
Mecklin, John M. The Ku Klux Klan: a Study of the American Mind. New York: Harcourt, Brace, and Company, 1924.

Michaeli, Ethan. The Defender: How the Legendary Black Newspaper Changed America. Boston: Houghton Mifflin Harcourt, 2016.

Miller, Merle. Plain Speaking: An Oral Biography of Harry S. Truman. New York: Berkley Publishing Corporation, 1974

Miller, Richard Lawrence. Truman: The Rise to Power. New York: McGraw-Hill Book Company, 1986.

Mitchell, Franklin D. Embattled Democracy: Missouri Democratic Politics, 1919-1932. Columbia: University of Missouri Press, 1968.

Mitchell, Franklin D. "The Re-Election of Irreconcilable James A. Reed," Missouri Historical Review 60 no. 4 (July 1966): 416-435.

Moore, Deborah Dash. B'nai B'rith and the Challenge of Ethnic Leadership. Albany: State University Press of New York, 1981.

Moore, Jr., Jesse Thomas. A Search for Equality: The National Urban League, 19101961. University Park: Pennsylvania State University Press, 1981.

Moore, Leonard J. Citizen Klansmen: the Ku Klux Klan in Indiana, 1921-1928. Chapel Hill: University of North Carolina Press, 1991.

Mutti Burke, Diane. On Slavery's Border: Missouri's Small Slaveholding Households, 1815-1865. Athens: University of Georgia Press, 2010.

Nelson, Lawrence J. Rumors of Indiscretion: The University of Missouri's "Sex Questionnaire” Scandal in the Jazz Age. Columbia: University of Missouri Press, 2003.

Nordstrom, Justin. Danger on the Doorstep: Anti-Catholicism and American Print Culture in the Progressive Era. Notre Dame: University of Notre Dame, 2006.

Painter, Nell Irvin. Exodusters: Black Migration to Kansas After Reconstruction. New York: Alfred A. Knopf, 1977.

Parrish, William E. A History of Missouri: Volume III, 1860 to 1875. Columbia: University of Missouri Press, 1973.

Parrish, William E. Missouri Under Radical Rule, 1865-1870. Columbia: University of Missouri Press, 1965.

Parsons, Elaine Frantz. Ku-Klux: The Birth of the Klan during Reconstruction. Chapel Hill: University of North Carolina Press, 2016. 
Pasley, Jeffrey L. "Harbinger of the New Deal Coalition: The Pendergast Machine and the Liberal Transformation of the Democratic Party." The Kansas City Public Library, 15 March 2018, http://pendergastkc.org/article/harbinger-new-dealcoalition-pendergast-machine-and-liberal-transformation-democratic-party.

Pearce, Matt. “A Century Ago, A Popular Missouri Newspaper Demonized a Religious Minority: Catholics." Los Angeles Times. 9 December 2015. http://www.latimes.com/nation/la-na-catholic-scare-20151209-story.html

Pegram, Thomas R. One Hundred Percent American: The Rebirth and Decline of the Ku Klux Klan in the 1920s. Chicago: Ivan R. Dee, 2011.

Peterson, Norma L. "The Political Fluctuations of B. Gratz Brown: Politics in a Border State, 1850-1870," Missouri Historical Review 51, no.1 (October 1956): 22-30.

Peterson, Sandra Rubinstein. “One Heart, Many Souls”: The National Council of Jewish Women and Identity Formation in St. Louis, 1919-1950. Ph.D. Diss.: University of Missouri-Columbia, 2008.

Primm, James Neal. Lion of the Valley: St. Louis, Missouri, 1764-1980, Third Edition. St. Louis: Missouri Historical Society Press, 1998.

Reed, Toure. Not Alms But Opportunity: The Urban League and the Politics of Racial Uplift, 1910-1950. Chapel Hill: University of North Carolina Press, 2008.

Rhodes, Joel P. A Missouri Railroad Pioneer: The Life of Louis Houck. Columbia: University of Missouri Press, 2008.

Ribuffo, Leo P. "Henry Ford and The International Jew.” In The American Jewish Experience: Second Edition, edited by Jonathan D. Sarna, 201-216. New York: Holmes \& Meier, 1997.

River of Faith: St. Margaret of Antioch Catholic Church, Osage Bend, Missouri, Centennial 1907-2007. Osage Bend, MO, 2007.

Rives, Timothy. "The Second Ku Klux Klan In Kansas City: Rise And Fall Of A White Nationalist Movement.” The Kansas City Public Library, 15 March 2018, http://pendergastkc.org/article/second-ku-klux-klan-kansas-city-rise-and-fallwhite-nationalist-movement.

Rolinson, Mary G. Grassroots Garveyism: The Universal Negro Improvement Association in the Rural South, 1920-1927. Chapel Hill: University of North Carolina Press, 2007.

Roll, Jarod. Spirit of Rebellion: Labor and Religion in the New Cotton South. Urbana: University of Illinois Press, 2010. 
Rush, Barbara J. The Ku Klux Klan in Kansas City during the Twenties. Master's Thesis, Marquette University, 1970.

Ryan, Yvonne. Roy Wilkins: The Quiet Revolutionary and the NAACP. Lexington: University of Kentucky Press, 2014.

Sable, Jacob M. Some American Jewish Organizational Efforts to Combat Anti-Semitism, 1906-30. Ph.D. Diss., Yeshiva University, 1964.

Sandweiss, Eric. St. Louis: The Evolution of an American Urban Landscape. Philadelphia: Temple University Press, 2001.

Sarna, Jonathan D. American Judaism: A History. New Haven: Yale University Press, 2004.

Savage, W. Sherman. The History of Lincoln University. Jefferson City: The New Day Press, 1939.

Schirmer, Sherry Lamb. A City Divided: The Racial Landscape of Kansas City, 19001960. Columbia: University of Missouri Press, 2002.

Schmidt, Daniel A. The Heritage of St. Thomas: Community-City-Parish; Showing the Early Development, Expanding Civilization, and Resources of a Progressive Community through Sketches of the People and Events Who have made its Past and whose Lives are Moulding its Future. Bob Dew Printing Company, 1974.

Schmidt, Joseph H. "Recollections of the First Catholic Missions in Central Missouri," Missouri Historical Review 5, no. 2 (January 1911):83-93.

Schneider, John C. "Riot and Reaction in St. Louis, 1854 - 1856." Missouri Historical Review 68, no. 2 (1974): 171-185.

Schultz, Joseph P. ed. Mid-America's Promise: A Profile of Kansas City Jewry. Kansas City: The Jewish Community Foundation of Greater Kansas City, 1982.

Schwalm, Leslie. Emancipation's Diaspora: Race and Reconstruction in the Upper Midwest. Chapel Hill: University of North Carolina Press, 2009.

Silver, M.M. Louis Marshall and the Rise of Jewish Ethnicity in American: A Biography. Syracuse: Syracuse University Press, 2013.

Smith, Gene. Until the Last Trumpet Sounds: The Life of General of the Armies John J. Pershing. New York: Wiley, 1998.

Snow, Thad. From Missouri: An American Farmer Looks Back. Edited by Bonnie Stepenoff. Columbia: University of Missouri Press, 2012. 
Stein, Judith. The World of Marcus Garvey: Race and Class in Modern Society. Baton Rouge: Louisiana State University Press, 1986.

Steinberg, Alfred. The Man from Missouri: the Life and Times of Harry S. Truman. New York: Putnam, 1962.

Stepenoff, Bonnie. Thad Snow: A Life of Social Reform in the Missouri Bootheel. Columbia: University of Missouri Press, 2003.

St. Stanislaus Parish, Wardsville, Missouri : 1880-1980. Wardsville, MO, 1980.

Sullivan, Patricia. Life Every Voice: The NAACP and the Making of the Civil Rights Movement. New York: The New Press, 2009.

Thelen, David. Paths of Resistance: Tradition and Democracy in Industrializing Missouri. Columbia: University of Missouri Press, 1991.

This Far by Faith: A Popular History of the Catholic People of West and Northwest Missouri. Kansas City: Diocese of Kansas City-St. Joseph, 1992.

Trinity Lutheran Church, Jefferson City, Missouri, Centennial 1970. Jefferson City, MO, 1970.

Truman, Margaret. Harry S. Truman. New York: William Morrow \& Company, Inc., 1973.

Turner, Stephen. "A Life in the First Half-Century of Sociology: Charles Ellwood and the Division of Sociology." In Sociology in America: A History, edited by Craig Calhoun, 115-154. Chicago: University of Chicago Press, 2007.

Tyrrell, Ian. Woman's World, Woman's Empire: The Woman's Christian Temperance Union in International Perspective, 1880-1930. Chapel Hill: University of North Carolina Press, 1991.

Vandiver, Frank. Black Jack: The Life and Times of John J. Pershing. College Station: Texas A\&M University Press, 1977.

Wade, Wyn C. The Fiery Cross: the Ku Klux Klan in America. New York: Oxford University Press, 1998.

Watts, Steven. The People's Tycoon: Henry Ford and the American Century. New York: Alfred A. Knopf, 2005.

Weiss, Nancy. The National Urban League, 1910-1940. Oxford: Oxford University Press, 1974. 
Weissbach, Lee Shai. Jewish Life in Small-Town America. New Haven: Yale University Press, 2005.

Wilkerson, Isabel. The Warmth of Other Suns: The Epic Story of America's Great Migration. New York: Random House, 2010.

Wilkins, Roy. Standing Fast: The Autobiography of Roy Wilkins. New York: The Viking Press, 1982.

Wilson, Thomas D. "Chester A. Franklin and Harry S. Truman: An African-American Conservative and the 'Conversion' of the Future President," Missouri Historical Review 88, no. 1 (October 1993): 48-77.

Wood, Amy Louis. Lynching and Spectacle: Witnessing Racial Violence in America, 1890-1940. Chapel Hill: University of North Carolina Press, 2009.

Worley, William S. J.C. Nichols and the Shaping of Kansas City: Innovation in Planned Residential Communities. Columbia: University of Missouri Press, 1990.

Yacovazzi, Cassandra. "So Many Foolish Virgins": Nuns and Anti-Catholicism from Maria Monk to the Know-Nothings. Ph.D. Diss., University of MissouriColumbia, 2015. 


\section{VITA}

A native Missourian, Sean Rost completed a B.S. in History Education at William Woods University in 2009, and an M.A. in History at Lincoln University in 2011. Before enrolling in the doctoral program at the University of Missouri-Columbia, he taught two semesters of survey courses in United States History as an adjunct instructor for Columbia College-Jefferson City. During his doctoral studies, he also taught United States History at William Woods University, Westminster College, and the University of Missouri-Columbia. Presently, he is the Oral Historian for the State Historical Society of Missouri and the Missouri Humanities Council. 